\title{
energies
}

Innovation in

Energy Security

and Long-Term

Energy Efficiency

Edited by

Manuela Tvaronavičienè

Printed Edition of the Special Issue Published in Energies 


\section{Innovation in Energy Security and Long-Term Energy Efficiency}





\section{Innovation in Energy Security and Long-Term Energy Efficiency}

Editor

Manuela Tvaronavičienè 
Editor

Manuela Tvaronavičienè

Vilnius Gediminas Technical University

Lithuania

Editorial Office

MDPI

St. Alban-Anlage 66

4052 Basel, Switzerland

This is a reprint of articles from the Special Issue published online in the open access journal Energies (ISSN 1996-1073) (available at: https://www.mdpi.com/journal/energies/special_issues/ Energy_Security_Energy_Efficiency).

For citation purposes, cite each article independently as indicated on the article page online and as indicated below:

LastName, A.A.; LastName, B.B.; LastName, C.C. Article Title. Journal Name Year, Article Number, Page Range.

ISBN 978-3-03936-902-7 (Hbk)

ISBN 978-3-03936-903-4 (PDF)

(C) 2020 by the authors. Articles in this book are Open Access and distributed under the Creative Commons Attribution (CC BY) license, which allows users to download, copy and build upon published articles, as long as the author and publisher are properly credited, which ensures maximum dissemination and a wider impact of our publications.

The book as a whole is distributed by MDPI under the terms and conditions of the Creative Commons license CC BY-NC-ND. 


\section{Contents}

About the Editor $\ldots \ldots \ldots \ldots \ldots \ldots \ldots \ldots \ldots \ldots \ldots$

Mihaela Simionescu, Yuriy Bilan, Emília Kraj ňáková, Dalia Streimikiene and

Stanisław Gędek

Renewable Energy in the Electricity Sector and GDP per Capita in the European Union

Reprinted from: Brain Sciences 2019, 12, 2520, doi:10.3390/en12132520 . . . . . . . . . . . . . .

Mangirdas Morkunas, Gintaras Cernius and Gintare Giriuniene

Assessing Business Risks of Natural Gas Trading Companies: Evidence from GET Baltic

Reprinted from: Brain Sciences 2019, 12, 2647, doi:10.3390/en12142647 . . . . . . . . . . . . . . .

Serhiy Lyeonov, Tetyana Pimonenko, Yuriy Bilan, Dalia Štreimikienė and Grzegorz Mentel

Assessment of Green Investments' Impact on Sustainable Development: Linking Gross

Domestic Product Per Capita, Greenhouse Gas Emissions and Renewable Energy

Reprinted from: Brain Sciences 2019, 12, 3891, doi:10.3390/en12203891

Rasa Smaliukiene, Gintaras Labutis and Ausrius Juozapavicius

Pro-Environmental Energy Behavior in the Military: Assessing Behavior Change Factors at a

Selected Military Unit

Reprinted from: Brain Sciences 2020, 13, 219, doi:10.3390/en13010219 _ . . . . . . . . . . . . 43

Jolanta Sabaitytė, Vida Davidavičienė and Gerard Frederick Van Kleef

The Peculiarities of Low-Cost Carrier Development in Europe

Reprinted from: Brain Sciences 2020, 13, 639, doi:10.3390/en13030639 _ . . . . . . . . . . . 55

Yelena Petrenko, Igor Denisov, Gaukhar Koshebayeva and Valeriy Biryukov

Energy Efficiency of Kazakhstan Enterprises: Unexpected Findings

Reprinted from: Brain Sciences 2020, 13, 1055, doi:10.3390/en13051055 . . . . . . . . . . . . 75

Mihaela Simionescu, Wadim Strielkowski and Manuela Tvaronavičienė

Renewable Energy in Final Energy Consumption and Income in the EU-28 Countries

Reprinted from: Brain Sciences 2020, 13, 2280, doi:10.3390/en13092280 . . . . . . . . . . . . 95

Kalon Si, Xin Long Xu and Hsing Hung Chen

Examining the Interactive Endogeneity Relationship between R\&D Investment and Financially

Sustainable Performance: Comparison from Different Types of Energy Enterprises

Reprinted from: Brain Sciences 2020, 13, 2332, doi:10.3390/en13092332 . . . . . . . . . . . . . . 113 



\section{About the Editor}

Manuela Tvaronavičienè is professor at Vilnius Gediminas Technical University and Jonas Zemaitis Military Academy of Lithuania. She was the national head of several international projects, financed by European Commission, author of numerous papers, editor of a book, published by Elsevier. Her research interests embrace wide range of topics in the area of sustainable development and security issues. ORCID ID: https:/ / orcid.org/0000-0002-9667-3730. 

Article

\title{
Renewable Energy in the Electricity Sector and GDP per Capita in the European Union
}

\author{
Mihaela Simionescu ${ }^{1}$, Yuriy Bilan ${ }^{2, *}$, Emília Krajňáková ${ }^{2}$, Dalia Streimikiene ${ }^{3}$ and \\ Stanisław Gędek ${ }^{4}$ \\ 1 Institute for Economic Forecasting of the Romanian Academy, 050711 Bucharest, Romania \\ 2 Faculty of Social and Economic Relations, Alexander Dubček University of Trenčín, Studentska 3, \\ 91150 Trenčín, Slovakia \\ 3 Kaunas Faculty, Vilnius University, Muitines 8, LT-44280 Kaunas, Lithuania \\ 4 Faculty of Management, Rzeszow University of Technology, 35-959 Rzeszów, Poland \\ * Correspondence: yuriy_bilan@yahoo.co.uk
}

Received: 9 June 2019; Accepted: 29 June 2019; Published: 30 June 2019

\begin{abstract}
Considering that the European Directive has imposed that at least 20\% of the total energy should come from renewable energy sources (RES) by 2020 already and the specific targets for each European Union Member State, this paper attempts to assess the importance of GDP per capita in realizing these targets and also the effects of the RES share in electricity. Contrary to previous research, this paper does not consider the connection between economic growth and RES, but rather the potential connection between the share of RES in electricity and the real GDP per capita. The panel data models indicated to a positive, but very low impact of GDP per capita on the share of RES in electricity in the period of 2007-2017 in the case of the EU countries, except Luxembourg that has outlier values of GDP per capita. However, causality between the two variables was not identified. Some groups of countries were described according to these variables using cluster analysis. Future research should focus on the extension of this model by including other important variables such as RES potential available in the countries with specific geographical conditions.
\end{abstract}

Keywords: renewable energy sources; electricity; GDP per capita

\section{Introduction}

In the last few decades, concerns about environmental security, sustainability and climate change have grown, forcing governments to find viable alternatives to the traditional energy sector to limit its negative impact on the environment. The use of renewable energy, even if expensive, reduces gas emissions that negatively influence the environment [1-3]. A world agreement has established the reduction of greenhouse gas emissions by $80-90 \%$ by 2050 [4]. Moreover, considering that fossil fuels will be depleted relatively soon, the reform of the energy sector has been considered a priority for the European Union (EU) and other regions of the world too. A potential solution to all these issues could be represented by the growth of renewable energy sources (RES) not only in energy consumption, but also in energy production [5]. Today's technologies are used to generate most part of the renewable energy, a significant part of it being obtained from biomass. In the last 15 years, generation of wind and solar energy has sharply increased at the global level. Experts predicted that by 2040 RES will have a share of $50 \%$ in the world energy consumption [6].

The demand for energy in European countries and the increasing wellbeing and standards of living determined these states to increase production and utilization of renewable energy $[7,8]$. Energy plays a central role in national economic development. It may also have a leverage effect on economic growth. The economic systems of the EU states are directly influenced by the energy policy at the EU level. The European energy system should respond to climate change challenges and support 
the achievement of sustainable growth in the EU member States [9]. The EU countries with higher GDP succeeded in making progress in production and utilization of renewable energies as higher economic development level provides more financial resources and opportunities to invest in new renewable energy technologies also taking into account geographical conditions of these countries [9]. Another possible explanation would be the fact that in the EU developed Member States the transition from fossil fuels to renewable energy sources is encouraged by well-developed national legislative frameworks and strong institutions. The implementation of RES technologies are not regulated by political actions. The subsidies, tax credits, financial assistance and rebates are well-established in favour of renewable technologies in developed market economies. Transition countries having lower GDP per capita and less developed energy markets, have weaker institutions and policy frameworks to support RES as well as less budget resources to provide financial support for RES technologies $[9,10]$.

Economic sustainability might be ensured by allocation of emission allowances and energy efficiency [10,11]. The Renewable Energy Directive, known as 2009/28/EC, establishes the EU policy in terms of energy production from RES. According to the mentioned directive a minimum of $20 \%$ RES in the total energy of the EU countries is required by 2020, specific targets being set up for each state. The framework on climate and energy as to 2030 imposes a minimum of $27 \%$ in what concerns the share of RES consumption [12-14].

RES development does not compromise economic growth or employment [12], moreover, it may bring some additional financial advantages [15]. The literature reports that there are business models that depend on the category of resources and various characteristics of industrialized and developing economies [16-18].

Solar power and wind are intermittent resources, but this disadvantage can be eliminated by cross-border and cross-sector cooperation $[19,20]$. The EU has proposed a low-carbon energy system with a growing share of renewable electricity sources [21] and an ambitious goal of $100 \%$ renewable energy [22].

Only eleven states have already achieved the 2020 targets [23]. A comparative research between the countries that might reach the national targets is necessary in this context. For instance, Denmark, Austria, Finland and Sweden are leaders in terms of the Europe 2020 Strategy [24] implementation, while France, Germany, Portugal, Italy, Lithuania, Croatia, Ireland, and Latvia have values greater than the EU average, with respect to environmental and energy performance [25]. Italy, Austria, Portugal, Latvia, and France are top performers in terms of environmental protection [26]. RES as capital influences the GDP, a retraction correction being observed when economic growth generates the growth of renewable energy consumption. The EU candidate countries need to foster the development of renewable energy [27]. For the EU-28, the results indicate that a growth of $1 \%$ in primary production of RES generates an increase of $0.05-0.06 \%$ in GDP per capita [28]. Trajectories towards national targets are also analyzed in [29]. Difficulties of several countries in reaching the targets can be described as follows: The Netherlands and Malta have problems with the levels of GHG emissions [30], while The Netherlands, France, Luxembourg, Ireland, and the United Kingdom encountered difficulties with the share of RES [31].

There is a plethora of studies [17-46] analyzing the relationship between renewable energy consumption and macroeconomic indicators from different perspectives and using different methodologies. A part of these studies constructed a renewable energy sustainability index that was applied for the $15 \mathrm{EU}$ countries that are different according to level of final energy consumption and degree of economic development [21]. Another study analyzed energy per capita for 19 Eurozone countries [25]. A consistent part of researches are focused on the relationship between energy consumption/renewable energy consumption and different macroeconomic variables, like economic growth in Europe (for the EU-28 countries [21], new EU member states [27], 42 developing countries [23], main renewable energy consuming countries in the world [25], 15 former Soviet Union countries [24],), capital and labour (new EU member states [29]), urbanization (residential sector [36]). Lung [31] offered own division into the groups of countries according to output and energy consumption basing 
on the data for both developed and developing countries. Previously, a comparative analysis among the EU-28 member states according to the RES share in gross final consumption was carried out by Cucchiella et al. [10] using different mathematical models. The authors showed that Finland and Sweden achieved the best results concerning gross final energy consumption, while Austria, Denmark, and Latvia reached the 2020 target in the share of energy from renewable sources in the gross final consumption. Moreover, the authors showed that some EU countries will never achieve the 2020 targets (France, Belgium, The Netherlands, Luxembourg, UK).

A special consideration was assigned to the advantages of renewable energy technologies in the case of emerging countries $[40,41]$. Sadorsky proposed two empirical models to capture the connection between income and renewable energy consumption in some emerging economies. A cointegration relationship was identified and growth in the case of real per capita income had a positive and significant influence on per capita renewable energy consumption. If real income per capita grows by $1 \%$ in the long run, consumption of renewable energy per capita in emerging economies increases by around $3.5 \%$ [42].

There are many studies dealing with forecasts of energy consumption from renewables based on various quantitative methods and on the data of the EU-28 countries [43-50] Considering the European Commission principal objective to extend the share of renewable energy production in electricity, the aim of this research is to explain the renewable energy in electricity based on GDP per capita, seen as a measure of standard of living and income inside the EU, in the period of 2007-2017. Knowing the advantages of RES related to environmental protection and reduction of GHG emissions, this paper checks whether the increase in renewable energy in electricity has a positive effect on the EU countries' economies. This objective is achieved by focusing on two directions of research: the explanation of a share of renewable energy in electricity based on GDP per capita using panel data models and checking Granger causality on stationary panel data, and the study of groups of the EU countries according to their shares of renewable energy in electricity using cluster analysis.

Most of the studies in literature address energy consumption in its correlation to various macroeconomic indicators, less attention being given to the analysis of the renewable energy in the electricity subsector specifically.

This analysis provides useful conclusions on the share of renewable energy in electricity in relation to output per capita, while all previous studies have been connecting this indicator only with economic growth. None of the studies links the share of renewable energy in electricity to per capita GDP. The novelty of this research is also ensured by application of other methods than those used before to study this kind of relationship. In our case, the results based on an overall analysis of the countries using panel data analysis are combined with the results on individual analysis of the countries based on cluster method.

The paper has a standard logical organization. The current section provides details on theoretical background with some references from literature, while the methodology is presented briefly in Section 2. In Section 3, we report the main results with corresponding economic comments. Finally, in the last section, a deeper discussion is presented.

\section{Method and Data}

As we mentioned before, the share of renewable energy in electricity will be analyzed in relation with real GDP per capita for the EU-28 countries. This empirical study employs two methods: panel data models, including the study of causality in panel, and cluster analysis for identifying groups of countries according to share of renewable energy in electricity and their economic development expressed by GDP per capita.

The variables that have been employed in this research refer to the share of renewable energy in electricity (\%), the supply of electricity as gross electricity production in Gigawatt-hour, electricity price for non-household consumption in Purchasing Power Standard (consumption less than $20 \mathrm{MWh}$-band IA, comparable prices) and real GDP per capita (expressed in constant 2010 US dollars). The data 
on these variables were collected for the EU-28 countries for the period of 2007-2017. The data on the share of renewable energy in electricity are taken from the Statista database, while the World Bank provided the data for GDP per capita. The data on electricity supply and electricity prices for non-households are provided from the Eurostat database and the supply of energy plays the role of a control variable in the panel data models. Other theoretical and empirical studies used $\mathrm{CO}_{2}, \mathrm{GHG}$ emissions or population as their explanatory variables [8,9]. The data on $\mathrm{CO}_{2}$ and $\mathrm{GHG}$ emissions are not available for the analyzed period for all the EU Member States. Population is not relevant in this case since GDP per capita is an indicator computed using data on population. Data on electricity price per household consumption are available only since 2017.

In this paper, renewable energy sources (RES) refer to those sources of energy that are flow-limited and naturally replenishing: biomass (biodiesel, wood, solid and wood waste, ethanol, biogas, landfill gas), wind, hydropower, solar source, geothermal sources etc. This indicator shows the proportion of electricity derived from renewable sources in each EU country.

The electricity prices for non-household consumers are computed for end users based on the predefined yearly consumption band. Three levels of taxation are considered in calculation of these prices (prices excluding VAT and the rest of recoverable taxes, prices excluding levies and taxes, prices including all taxes, VAT and levies). Gross electricity production/generation describes the process of producing electrical energy. In this case, electrical energy is obtained by transforming different other existing forms of energy. Luxembourg is the country with the highest values of the GDP per capita in the entire period, these values being considered outliers. The maximum value of this indicator was achieved by Luxembourg in 2015 (77,400 constant 2010 US dollars). Bulgaria is the country with the lowest values of GDP per capita, the minimum being registered in $2007(10,400$ constant 2010 US dollars). Considering the global economic crisis started in 2008 in the US, all the countries, but for Poland, registered lower values of GDP per capita in 2009 as compared to 2008, the effects of the crisis being immediately reflected in the values of output per capita. In Poland, the GDP per capita maintained its value on the 2008 level. Indeed, Poland is considered to be the single EU country not affected by the recent world economic crisis due to its large local market and favourable business environment. Austria has the highest shares of renewable energy in electricity in the EU, the maximum value being achieved in 2017 (72.6\%), being also among the countries with high values of GDP per capita. On the other hand, Malta is the state with the lowest share of renewable energy in electricity, a null value being registered in the period of 2007-2010. Some causes for low performance of Malta would be: small population, planning policies that respond to the ascending demand of accommodation through buildings that require shadowing of rooftops instead of PV installation.

We will build traditional panel data models: fixed-effects model, random-effects model and model based on generalized estimating equation. The last type of model is used to explain the structure of the within-panel correlation. It corresponds to population-averaged (or marginal) models that are described in the panel-data literature.

The fixed-effects model has the following representation:

$$
Y_{i t}=\alpha+X^{1}{ }_{i t} \cdot \beta_{1}+\ldots+X^{k}{ }_{i t} \cdot \beta_{k}+\mu_{i}+v_{i t}
$$

where $\mathrm{Y}$ is the dependent variable, $\mathrm{X}$ - exogenous variables, $\mathrm{i}$-index for country, $\mathrm{t}$-index for year, $\mathrm{v}_{\mathrm{it}}$-idiosyncratic error, $\mu_{\mathrm{i}}$-error for cross-sections

The fixed-effect model uses the following assumptions:

- $\quad$ unobservable individual effects are considered as fixed parameters;

- $\quad$ the exogenous variables are not correlated with idiosyncratic error $v_{i t}$ but correlate with individual fixed effects;

- $\quad$ the idiosyncratic errors $v_{i t}$ should be independent and identically distributed (iid $\left(0, \sigma^{2}{ }_{v}\right)$. 
The random-effects model uses the following assumptions:

- unobservable individual effects are considered random variables;

- the exogenous variables do not correlate with idiosyncratic error $v_{\text {it }}$ or with individual effects;

- $\quad$ the idiosyncratic errors $v_{i t}$ should be independent and identically distributed (iid $\left(0, \sigma^{2}{ }_{v}\right)$ ) [51].

In the case of one explanatory variable, the model has the representation given below:

$$
\mathrm{Y}_{\mathrm{it}}=\alpha+\mathrm{X}_{\mathrm{it}} \cdot \beta+\mu_{\mathrm{i}}+\mathrm{v}_{\mathrm{it}}
$$

The average in time is obtained:

$$
\operatorname{average}\left(\mathrm{Y}_{\mathrm{i}}\right)=\alpha+\operatorname{average}\left(\mathrm{X}_{\mathrm{i}}\right) \cdot \beta+\mu_{\mathrm{i}}+\operatorname{average}\left(\mathrm{v}_{\mathrm{i}}\right)
$$

The difference between the two previous equations is made:

$$
\mathrm{Y}_{\mathrm{it}}-\operatorname{average}\left(\mathrm{Y}_{\mathrm{i}}\right)=\left(\mathrm{X}_{\mathrm{it}}-\operatorname{average}\left(\mathrm{X}_{\mathrm{i}}\right)\right) \cdot \beta+\left(\mathrm{v}_{\mathrm{it}}-\operatorname{average}\left(\mathrm{v}_{\mathrm{i}}\right)\right)
$$

This internal transformation is required for determining the fixed-effect estimator. The least squares method is applied in the model (4) and the estimators for $\beta$ with fixed-effects are calculated.

For testing Granger causality in panel data, we should start from the regression:

$$
\mathrm{Y}_{\mathrm{it}}=\alpha_{\mathrm{i}}+\sum \mathrm{Y}_{\mathrm{i}(\mathrm{t}-\mathrm{k})} \cdot \beta_{\mathrm{ik}}+\sum \mathrm{X}_{\mathrm{i}(\mathrm{t}-\mathrm{k})} \gamma_{\mathrm{ik}}+\varepsilon_{\mathrm{it}}
$$

The data series for variables $X$ and $Y$ should be stationary to check Granger causality between them. The coefficients should differ across countries ( $t-i n d e x$ for time, $i$-index for countries), but are constant in time. The lag order is $\mathrm{K}$ and it should be constant for all the countries in the balanced panel. Granger causality test implies the identification of significant effects of previous values of $X$ on the actual values of $Y$. The null hypothesis is stated as:

H0: $\gamma_{\mathrm{i} 1}=\gamma_{\mathrm{i} 2}=\ldots=\gamma_{\mathrm{iK}}=0, \mathrm{i}=1,2, \ldots, \mathrm{N}$; where $\mathrm{N}$ is the number of cross-sections (countries)

Firstly, the data stationarity was checked using a Levin-Lin-Chu (LLC) test and further estimations are made on stationary panel data. The null hypothesis for LLC test states that the panels include unit root, while the alternative hypothesis, rejected when the p-value is higher than $0.05 / 0.1$ (at the $5 \%$ and $\mathrm{s}$ of significance), confirms that panels are stationary. We chose the estimates with robust standard errors in order to avoid additional checks for errors' heteroskedasticity loose the critical value or when the p-value is higher than $0.05 / 0.1$, at the $5 \% / 10 \%$ levels of significance.

Cluster analysis is used to identify groups of countries by GDP per capita and share of renewable energy in electricity. In this case, we used a non-hierarchical classification with K-mean clusters. The k-average method starts from $\mathrm{k}$ values that are used to build groups. The distance to cluster is computed using the Ward method that implies more steps:

- for the analyzed variable, the sum of the squares of the deviations of each country in the cluster from average is computed, in order to minimize the square of the error squares, for example, to minimize the loss of information;

- $\quad$ for every step of the algorithm, any pair of countries that could be joined in a particular cluster is analyzed and we unify the pair that with the minimum loss of information.

There is not any strong statistical criterion for determining the number of clusters that should be considered at a certain probability. The optimal number of clusters is fixed considering some hints:

- $\quad$ theoretical motivation;

- previous use of non-hierarchical methods; 
- $\quad$ results of variance analysis;

- $\quad$ figures representing the countries.

The k-means method supposes the following steps:

(1) k initial classes are considered (each country is placed in one class);

(2) A country is moved in that cluster for which the average or centroid is the closest;

(3) The average is computed again for the two clusters in which that country was at different moments;

(4) The previous two steps are repeated until changes are made.

We have chosen a panel data approach since we are describing here an overall image of the relationship between RES in electricity and GDP per capita in the EU countries. Moreover, cluster analysis was applied in order to have a deeper understanding on the tendencies in each country.

\section{Empirical Results}

A Nalimov test was applied to check for outliers in the data series. For Luxembourg, all the values of GDP per capita were outliers since the test statistics (for example, 18.93 for 2007 and 27.99 for 2017) were higher than the critical value of 1.95 at the $5 \%$ level of significance. Since Luxembourg is considered an outlier because of the high level of GDP per capita, we eliminated this country from the panel data models. Two main goals were followed by the empirical analysis:

- $\quad$ A study of the relationship between share of renewable energy in electricity and GDP per capita based on panel data models and Granger causality;

- An analysis of the groups of countries in the EU-28 according to share of renewable energy in electricity and GDP per capita.

All the computations were made using the STATA software. Firstly, we tested whether the data in panel are stationary. Levin-Lin-Chu test indicated that the data series for both variables are stationary at the $10 \%$ level of significance. According to LLC test, the data series are stationary in panel for all the variables at the $10 \%$ level of significance: GDP per capita (adjusted $t=4.23, p$-value $=0.000$ ), supply of electricity (adjusted $t=1.98, p$-value $=0.09$ ), electricity prices for non-household consumers (adjusted $\mathrm{t}=2.23, p$-value $=0.04$ ).

More panel data models were built to explain the share of renewable energy in electricity in the EU-28 countries in the period of 2007-2017: generalized linear models, random-effects and fixed-effects models. According to Pesaran's CD test, the cross-sectional units are independent at the $5 \%$ level of significance. All the models indicated that growth of GDP per capita by one unit determined, on average, an increase in the share of renewable energy in electricity by almost 0.001 percentage points. In other words, an increase in GDP per capita by 1000 units are necessary to extend the share of renewable energy in electricity by only one percentage points (see Table 1).

Table 1. Panel data models to explain the share of renewable energy in electricity in the EU member states (2007-2017).

\begin{tabular}{|c|c|c|c|c|c|c|c|c|c|}
\hline \multirow[t]{2}{*}{ Variable } & \multicolumn{3}{|c|}{ Generalized Estimating Equation } & \multicolumn{3}{|c|}{ Random-Effects GLS Equation } & \multicolumn{3}{|c|}{ Fixed-Effects (within) Regression } \\
\hline & Coefficient & $\begin{array}{l}\text { Chi-square } \\
\text { stat. }\end{array}$ & $p$-value & Coefficient & $\begin{array}{l}\text { Chi-square } \\
\text { stat. }\end{array}$ & $p$-value & Coefficient & $\begin{array}{l}\text { Chi-square } \\
\text { stat. }\end{array}$ & $p$-value \\
\hline GDP per capita & 0.0009 & 9.38 & 0.000 & 0.0009 & 8.54 & 0.000 & 0.001 & 9.51 & 0.000 \\
\hline Constant & -1.52 & -0.32 & 0.70 & -0.15882 & -0.04 & 0.969 & -1.92 & -1.44 & 0.17 \\
\hline Supply of electricity & 0.89 & 7.99 & 0.000 & 0.92 & 9.03 & 0.000 & 0.89 & 9.20 & 0.000 \\
\hline $\begin{array}{l}\text { Electricity price for } \\
\text { non-household } \\
\text { consumption }\end{array}$ & 0.005 & 8.32 & 0.000 & 0.0049 & 7.78 & 0.000 & 0.005 & 8.00 & 0.000 \\
\hline $\begin{array}{l}\text { Pesaran's test for } \\
\text { cross-section } \\
\text { independence }\end{array}$ & & 12.27 & 0.14 & & 13.56 & 0.27 & & 12.57 & 0.15 \\
\hline
\end{tabular}

Source: own results. 
This result indicates that other factors should contribute to the growing share of renewable energy in electricity, maintaining the concern for growing GDP per capita. This result supports the hypothesis stated in the introduction: more developed countries tend to use more RES as compared to less developed countries. However, still more efforts to grow GDP per capita are required in the EU to have an acceptable increase in RES. As expected, the control variable (electricity supply) has a positive and significant impact on the dependent variable. The increase in electricity production overall brought to a higher share of renewable energy in electricity. In other words, renewable energy is more used in electricity since electricity production overall has increased to correspond to the growing needs in energy. We applied a Hausmann test to select the best model between fixed-effects model and random-effects model. The statistics of the test is 45.78 ( $p$-value $=0.000$ ) which indicates that fixed-effects model explains better than random-effects model the share of renewable energy in electricity in the EU countries at the $5 \%$ level of significance. The values of R-square also indicate fixed-effects model as better (R-square in this case is 0.803 , while for random-effects model R-square is 0.71 and for generalized estimating equation R-square is 0.76 ). This can be explained by the fact that the increase in electricity prices shapes the of renewables in the increase of the share of renewables in electricity production. However, a significant causality in Granger approach was not identified between GDP per capita and share of renewable energy in electricity at $5 \%$ level of significance (see Table 2).

Table 2. Granger causality test applied on panel data to explain the connection between the share of renewable energy in electricity and GDP per capita in the EU-28 (2007-2017).

\begin{tabular}{ccc}
\hline Hypothesis & Chi-Square & Prob. \\
\hline $\begin{array}{c}\text { Share of renewable energy in electricity does } \\
\text { Granger cause GDP per capita }\end{array}$ & 2.307 & 0.3155 \\
\hline $\begin{array}{c}\text { GDP per capita does Granger cause share of } \\
\text { renewable energy in electricity }\end{array}$ & 3.039 & 0.218 \\
\hline
\end{tabular}

Source: own results.

Some clusters were formed for 2007 and 2017 to reflect the countries in what concerns share of renewable energy in electricity and according to the share of renewable energy in electricity and GDP per capita.

According to the share of renewable energy in electricity, Table 3 describes the two clusters obtained for 2007:

- $\quad$ countries with high shares of renewable energy in electricity (more than 30\%): Austria (64\%), Sweden (53.2\%), Latvia (38.6\%), Croatia (34\%) and Portugal $(32.3 \%)$ (these percentages are provided to have an idea about the difference between the countries in the same group);

- $\quad$ countries having lower shares of renewable energy in electricity (less than $30 \%$ ) for the rest of the EU-28 countries.

When both the share of renewable energy in electricity and GDP per capita are considered, Table 3 presents a number of three clusters in 2007:

- $\quad$ countries having high GDP per capita and relative high shares of renewable energy in electricity;

- Luxemburg that is considered an outlier because of the high values of GDP per capita;

- $\quad$ some countries with lower GDP per capita.

Two clusters were selected for the share of renewable energy in electricity and three clusters for the approach based on both variables. We selected these numbers since significant differences between the groups were allowed. We have thee clusters for the second approach, since Luxembourg is an outlier that is different from all other countries. 
Table 3. Groups of countries in the EU-28 according to the share of renewable energy in electricity and GDP per capita in 2007.

\begin{tabular}{|c|c|c|c|c|}
\hline \multicolumn{2}{|c|}{$\begin{array}{l}\text { Clusters according to the Share of } \\
\text { Renewable Energy in Electricity in } 2007\end{array}$} & \multicolumn{3}{|c|}{$\begin{array}{l}\text { Clusters according to the Share of Renewable Energy in } \\
\text { Electricity and GDP per Capita in } 2007\end{array}$} \\
\hline Cluster 1 & Cluster 2 & Cluster 1 & Cluster 2 & Cluster 3 \\
\hline $\begin{array}{c}\text { Austria, Portugal, } \\
\text { Croatia, Latvia, } \\
\text { Sweden }\end{array}$ & $\begin{array}{l}\text { Bulgaria, Belgium, } \\
\text { Cyprus, Estonia, } \\
\text { Denmark, Finland, } \\
\text { Greece, Hungary, } \\
\text { France, Germany, } \\
\text { Ireland, Italy, } \\
\text { Poland, Slovenia, } \\
\text { Lithuania, Malta, } \\
\text { Spain, Netherlands, } \\
\text { Romania, Slovakia, } \\
\text { the UK, } \\
\text { Luxembourg }\end{array}$ & $\begin{array}{c}\text { Austria, Belgium, } \\
\text { Cyprus, Denmark, } \\
\text { Finland, France, } \\
\text { Germany, Ireland, } \\
\text { Italy, Netherlands, } \\
\text { Spain, UK, Sweden }\end{array}$ & Luxembourg & $\begin{array}{c}\text { Croatia, Bulgaria, } \\
\text { Czech Republic, } \\
\text { Estonia, Greece, } \\
\text { Hungary, Latvia, } \\
\text { Lithuania, Malta, } \\
\text { Poland, Portugal, } \\
\text { Slovakia, Slovenia, } \\
\text { Romania }\end{array}$ \\
\hline
\end{tabular}

Source: own results.

As we can observe from Figure 1, Austria is the country with the highest share of renewable energy in electricity in 2007, but also in 2017, being followed by Sweden. Malta is the single country with null share of renewable energy in electricity in 2007, being followed by Cyprus with a share of $0.1 \%$ in 2007 . However, after 10 years, all the countries improved their share of renewable energy in electricity.

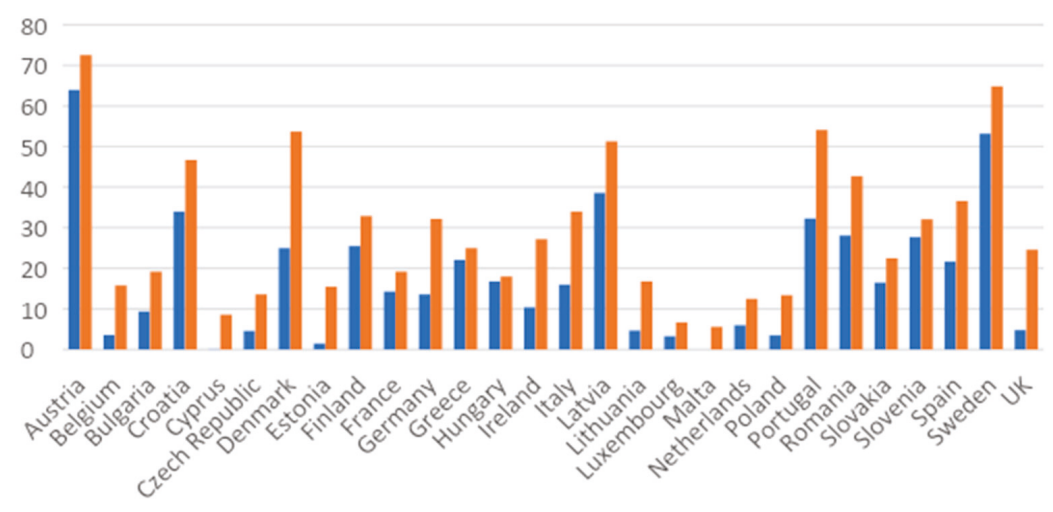

Figure 1. Share of renewable energy in electricity in 2007 and 2017 in the EU-28 countries (blue-2007, orange-2017). Source: own results.

Austria was the leader in 2007 in terms of share of renewable energy in electricity, this country being successful in what concern sources like biomass from wood, hydropower (a share of more than $96 \%$ in renewable energy in electricity) and use of thermal solar energy [47,51].

$80 \%$ percent of electricity production in Sweden is based on hydroelectric and nuclear power, fact that explains the low emission rate in this country. It has three nuclear plants and eight nuclear reactors. Wind power ensures around 11 percent of electricity, power plants and hear ensure nine percent of electricity in Sweden [52].

In Latvia, hydropower plants have the highest proportion in electricity production (more than $98 \%$ ). Gas also has a significant contribution to internal supply of electricity, wind and biomass contributing to the mix mostly in recent years [53]. 
In Croatia, renewable energy rapidly expanded. Wind and solar PV energy the most rapidly expanded, while hydropower and solar thermal developed slower [54].

In Portugal, the main sources of renewable energy are represented by: hydropower, wind power, solar power, geothermal and wave power, biogas [55].

According to share of renewable energy in electricity, Table 4 shows that there are two clusters in 2017:

- $\quad$ a group of countries with high shares of renewable energy in electricity (more than $40 \%$ which is an increase compared to 2007): Austria (72.6\%), Sweden (64.9\%), Latvia (51.3\%), Croatia (46.7\%), Denmark (53.7\%), Romania (42.7\%) and Portugal (54.1\%);

- a group of countries with lower shares of renewable energy in electricity (less than $40 \%$ ) in the case of the other EU-28 countries.

According to share of renewable energy in electricity and GDP per capita, Table 4 shows that there are three clusters in 2017:

- $\quad$ a group of countries with high GDP per capita and relative high shares of renewable energy in electricity;

- $\quad$ Luxemburg that is considered an outlier in terms of GDP per capita;

- $\quad$ a group of countries with lower GDP per capita.

Table 4. Groups of EU countries according to share of renewable energy in electricity and GDP per capita in 2017.

\begin{tabular}{|c|c|c|c|c|}
\hline \multicolumn{2}{|c|}{$\begin{array}{l}\text { Clusters Based on Share of Renewable } \\
\text { Energy in Electricity in } 2017\end{array}$} & \multicolumn{3}{|c|}{$\begin{array}{l}\text { Clusters Based on Share of Renewable Energy in } \\
\text { Electricity and GDP per Capita in } 2017\end{array}$} \\
\hline Cluster 1 & Cluster 2 & Cluster 1 & Cluster 2 & Cluster 3 \\
\hline $\begin{array}{c}\text { Denmark, Austria, } \\
\text { Croatia, Portugal, } \\
\text { Latvia, Romania, } \\
\text { Sweden }\end{array}$ & $\begin{array}{l}\text { Belgium, Bulgaria, } \\
\text { Hungary, Italy, Cyprus, } \\
\text { Ireland, Netherlands, } \\
\text { Greece, Lithuania, } \\
\text { Estonia, Ireland, } \\
\text { Germany, Finland, } \\
\text { France, Luxembourg, } \\
\text { Slovakia, Poland, } \\
\text { Slovenia, Malta, UK }\end{array}$ & $\begin{array}{l}\text { Austria, France, } \\
\text { Belgium, Germany, } \\
\text { Netherlands, } \\
\text { Sweden }\end{array}$ & $\begin{array}{c}\text { UK, } \\
\text { Luxembourg, } \\
\text { Denmark, } \\
\text { Finland }\end{array}$ & $\begin{array}{l}\text { Croatia, Malta, } \\
\text { Bulgaria, Slovenia, } \\
\text { Czech Republic, } \\
\text { Italy, Estonia, } \\
\text { Romania, Portugal, } \\
\text { Slovakia, Greece, } \\
\text { Hungary, Cyprus, } \\
\text { Latvia, Lithuania, } \\
\text { Spain, Poland }\end{array}$ \\
\hline
\end{tabular}

In 2017, Denmark and Romania were the countries that achieved also high shares of renewable energy in electricity together with the states that acted like leaders in 2007. Denmark counts among world leading countries in wind energy production. Other sources are less used: wood, waste, solar power, straw, biogas. However, Denmark is among the countries with the less utilization of hydropower [56]. In Romania, biomass and biogas is the most considerable source of energy used in electricity, being followed by less used ones: wind, solar, hydro sources [57].

\section{Discussion}

This paper has aimed to assess the impact of GDP per capita on penetration of RES and its effects in improving real GDP per capita as well. The objective character of the achieved results is ensured by utilization of historical data and applied statistical methods. This work also highlights the importance of producing more energy from RES for the countries to improve their economic growth and standards of living as the increase in the share of renewables provides for increase in standards of living because RES are based on new technologies, create new jobs, boost external benefits for the society, including pollution reduction and 
The EU countries were distributed into two large groups basing on the shares of renewable energy in electricity. This research also confirms the necessity to implement important policy measures to promote more active use of RES, taking into account the RES potential available in a country.

One of the main goal in this research has been studying the relationship between the share of renewable energy in electricity and real GDP per capita. Many of the previous research focused on correlation between economic development and energy production or/and consumption. We have chosen GDP per capita since it reflects the achieved level of economic development in the long run and population well-being is a final goal followed by all citizens, and also by government [58-62].

One of our important results is revealing the lack of causality between the two variables (the share of renewable energy in electricity and real GDP per capita). This means that production of energy from RES is not so high as to ensure on long-run economic welfare. Other important macroeconomic variables need to be taken into account when assessing the impact of RES on economic growth.

On the other hand, developed countries of the EU do not necessarily have high share of renewable energy in electricity and this is mainly linked to geographical conditions and physical renewable energy potential. There are numerous examples in this regard. Rich countries like Belgium, France, Germany, Ireland, Italy, The Netherlands, Luxembourg, and the UK registered shares of renewable energy in electricity lower than the EU average in 2007 [60]. Except for Germany, these countries also registered lower values than the 2017 European average for the same indicator.

The proposed panel data models suggested that GDP per capita influences the share of renewables in electricity positively and statistically significantly although this impact is very small. A consistent increase in the GDP per capita is necessary to extend the share of renewable energy in electricity [42]. Economic development level of a country has its impact on RES as it allows generating more financial resources to promote renewables as well advanced economies have better developed mature energy markets, better institutional indicators, industrial know-hows, community policies, technological development level, and citizens' openness to business having also positive impact on RES penetration [12,15].

One of the EU strategies is to reduce the final energy consumption and this objective could be achieved following two patterns: improvement of energy efficiency and growth of the share of renewable energy in final energy consumption and, as an effect of this by growing the share of renewable energy in electricity. If this goal is achieved, many benefits are obtained: sustainable development, reduction of global warming, environment protection, reduction of the dependence on energy imports [61].

The enhancement of renewable energy consumption has been observed since 2010 in the EU Member States, as an effect of EU Directive given in the year 2009 [62]. Even if most of the EU member states are on an upward trend, the achievement of the 2020 target it not secure, knowing that investments in renewable energy production have slowed down since 2015. Spain and Belgium focused more on the consumption of electricity from RES, the rest of the consumption being based on other types of fuels. Poland made important efforts to increase renewable energy consumption, but for achieving the 2020 target, has to boost production from RES. Austria, Denmark, Finland, and Sweden are countries where RES plays an important role in the energy mix [63]. In these countries, the lack of fossil fuel resources and the climatic conditions forced society and industry to reduce at minimum the energy consumption.

Even if significant investments were made in the UK for increasing the production capacity of RES, especially for solar panels, this country is far from achieving the EU target. The uncertain context of Brexit creates more barriers. Germany made big progress in the consumption of fossil and nuclear fuels, while France and Italy have serious problems in meeting the targets for 2020 [64-69]. Netherlands also encountered difficulties because its final energy consumption is based on a natural gas network that is quite cheap; government subsidies for the RES promotion are not attractive, being lower than in Scandinavian countries. 
Portugal has invested heavily in RES, but high costs did not allow it to maintain a high increase from one year to another. Czech Republic, Romania, and Hungary have a rich network of RES, but the efforts to meet EU target intensified after these countries joined the EU [70,71].

In some EU countries, the target value for 2020 in the case of share of renewable sources in gross final consumption was exceeded: Hungary and Estonia since 2011, Sweden and Bulgaria since 2012, Czech Republic since 2013, and Romania, Lithuania, Italy, and Finland since 2014. By increasing this share, the EU countries will be able to significantly reduce greenhouse gas emissions and improve the environment quality.

This analysis is limited by the fact that only a few variables were considered in the panel data models because of their availability for that specific period and for the EU countries. Moreover, a larger period would have been required for a deeper analysis, however, the data on all the variables in the models are available only since 2007. In the future other important variables will be included in the model and countries will be grouped into clusters according to their geographical conditions and physical RES potential available.

\section{Conclusions}

The panel data models indicated a positive, but very low impact of GDP per capita on the share of RES in electricity in the period of 2007-2017 in the case of the EU countries. However, causality between the two variables was not identified.

The EU member states were grouped by means of cluster analysis, however, future research would be necessary to get more robust results and develop specific policy recommendations. The extension of this model is required by including other important variables such as RES potential available in the countries based on geographical conditions and other important factors which were not addressed in this study.

Economic development level of countries is supposed to have significant impact on the exploration of RES potential taking into account geographical conditions of the countries in question. Higher economic development level first of all allows raising more funds for renewable energy support. As the old EU member states have also more developed energy markets, stronger institutions and legal frameworks, lower corruption perception levels, these issues need to be further explored.

Some other aspects need deeper analysis as well, namely, the political, social, economic, environmental, and technological determinants behind weaknesses and strengths of renewable resources. It is also important to assess the effects on RES expansion of the following specific factors: policies promoting RES, investments in the field of research and development, internal energy production, industrial know-hows, community policies, energy dependency, technological development level, and citizens' openness to business, institutional indicators such as corruption perception, regulation quality etc.

RES as such is supposed to have a positive impact on economic growth as it provides new jobs, technological innovations and also promotes GDP growth. Therefore, it is important to analyse the impact of RES deployment level on economic, social and environmental indicators of the countries, however, additional variables need to be integrated into the model as also having impact on GDP per capita growth rate.

Author Contributions: Conceptualization, M.S. and D.S.; Methodology, M.S., D.S., Y.B., E.K. and S.G.; Formal Analysis, M.S., Y.B. and E.K.; Investigation, Y.B., S.G. and D.S.; Resources, Y.B., E.K. and S.G.; Data Curation, M.S.; Writing-Original Draft Preparation, M.S., D.S. and S.G.; Writing—Review \& Editing, M.S. and D.S.; Visualization, M.S.; Supervision, D.S., Y.B. and E.K.; Funding Acquisition, Y.B., E.K. and S.G.

Funding: This research received no external funding.

Conflicts of Interest: The authors declare no conflict of interest. 


\section{References}

1. Wu, Q.; Zhou, J.; Liu, S.; Yang, X.; Ren, H. Multi-objective Optimization of Integrated Renewable Energy System Considering Economics and $\mathrm{CO}_{2}$ Emissions. Energy Procedia 2016, 104, 15-20. [CrossRef]

2. Dudin, M.N.; Frolova, E.E.; Protopopova, O.V.; Andrey Alievich Mamedov, A.A.; Odintsov, S.V. Study of innovative technologies in the energy industry: Nontraditional and renewable energy sources. Entrep. Sustain. Issues 2019, 6, 1704-1713. [CrossRef]

3. Lavrinenko, O.; Ignatjeva, S.; Ohotina, A.; Rybalkin, O.; Lazdans, D. The Role of Green Economy in Sustainable Development (Case Study: The EU States). Entrep. Sustain. Issues 2019, 6, 1013-1026. [CrossRef]

4. Pfenninger, S.; Keirstead, J. Renewables, nuclear, or fossil fuels? Scenarios for Great Britain's power system considering costs, emissions and energy security. Appl. Energy. 2015, 152, 83-93. [CrossRef]

5. Šahović, N.; da Silva, P.P. Community Renewable Energy-Research Perspectives. Energy Procedia. 2016, 106, 46-58. [CrossRef]

6. Sari, A.; Akkaya, M. Contribution of renewable energy potential to sustainable employment. Procedia Soc. Behav. Sci. 2016, 229, 316-325. [CrossRef]

7. European Parliament. Renewable Energy Sources. 2016. Available online: http://www.europarl.europa.eu/ $\mathrm{ftu} / \mathrm{pdf} / \mathrm{lv} /$ FTU_5.7.4.pdf (accessed on 3 December 2018).

8. Cherchyk, L.; Shershun, M.; Khumarova, N.; Mykytyn, T.; Cherchyk, A. Assessment of forest enterprises' performance: Integrating economic security and ecological impact. Entrep. Sustain. Issues 2019, 6, 1784-1797. [CrossRef]

9. Cucchiella, F.; Adamo, I.; Gastaldi, M. Biomethane: A renewable resource as vehicle fuel. Resources. 2017, 6, 58. [CrossRef]

10. Cucchiella, F.; D'Adamo, I.; Gastaldi, M.; Miliacca, M. Efficiency and allocation of emission allowances and energy consumption over more sustainable European economies. J. Clean. Prod. 2018, 182, 805-817. [CrossRef]

11. Tvaronavičienė, M.; Nesterova, K.; Kováčik, V. Energy security and long-term energy efficiency: Case of selected counties. J. Secur. Sustain. Issues 2017, 7, 349-357. [CrossRef]

12. Blazejczak, J.; Braun, F.G.; Edler, D.; Schill, W.-P. Economic effects of renewable energy expansion: A model-based analysis for germany. Renew. Sustain. Energy Rev. 2014, 40, 1070-1080. [CrossRef]

13. Frankfurt School UNEP Centre; Bloomberg New Energy Finance (BNEF). Global Trends in Renewable Energy Investment. Frankfurt School-UNEP Centre. 2016. Available online: http://fs-unep-centre.org/sites/default/ files/attachments/press_release_gtr_2016_in_english.pdf (accessed on 27 October 2017).

14. IEA. Energy and Climate Change, World Energy Outlook Special Report. Available online: https://www.iea. org/publications/freepublications/publication/WEO2015SpecialReportonEnergyandClimateChange.pdf (accessed on 7 November 2017).

15. Ruggiero, S.; Lehkonen, H. Renewable energy growth and the financial performance of electric utilities: A panel data study. J. Clean. Product. 2017, 142, 3676-3688. [CrossRef]

16. Engelken, M.; Römer, B.; Drescher, M.; Welpe, I.M.; Picot, A. Comparing drivers, barriers, and opportunities of business models for renewable energies: A review. Renew. Sustain. Energy Rev. 2016, 60, 795-809. [CrossRef]

17. Thellufsen, J.Z.; Lund, H. Cross-border versus cross-sector interconnectivity in renewable energy systems. Energy 2017, 124, 492-501. [CrossRef]

18. Eddelani, O.; El Idrissi, N.E.; Monni, S. Territorialized forms of production in Morocco: Provisional assessment for an own model in gestation. Insights Reg. Dev. 2019, 1, 6-18. [CrossRef]

19. Collins, S.; Deane, J.P.; Ó Gallachóir, B. Adding value to EU energy policy analysis using a multi-model approach with an EU-28 electricity dispatch model. Energy 2017, 130, 433-447. [CrossRef]

20. Masood, O.; Tvaronavičienė, M.; Javaria, K. Impact of oil prices on stock return: Evidence from G7 countries. Insights Reg. Dev. 2019, 1, 129-137. [CrossRef]

21. European Commission. A Policy Framework for Climate and Energy in the Period from 2020 to 2030; European Commission: Juba, South Sudan, 2014; Eurostat. Statistics Database. Available online: http://ec.Europa.Eu/ eurostat/data/database (accessed on 15 May 2017).

22. Fura, B.; Wojnar, J.; Kasprzyk, B. Ranking and classification of eu countries regarding their levels of implementation of the europe 2020 strategy. J. Clean. Prod. 2017, 165, 968-979. [CrossRef] 
23. Cucchiella, F.; D'Adamo, I.; Gastaldi, M.; Koh, S.C.L.; Rosa, P. A comparison of environmental and energetic performance of european countries: A sustainability index. Renew. Sustain. Energy Rev. 2017, 78, 401-413. [CrossRef]

24. García-Álvarez, M.T.; Moreno, B.; Soares, I. Analyzing the environmental and resource pressures from european energy activity: A comparative study of EU member states. Energy 2016, 115, 1375-1384. [CrossRef]

25. Armeanu, D.; Vintilă, G.; Gherghina, Ş. Does renewable energy drive sustainable economic growth? Multivariate panel data evidence for EU-28 countries. Energies 2017, 10, 381. [CrossRef]

26. Bilan, Y.; Streimikiene, D.; Vasylieva, T.; Lyulyov, O.; Pimonenko, T.; Pavlyk, A. Linking between Renewable Energy, $\mathrm{CO}_{2}$ Emissions, and Economic Growth: Challenges for Candidates and Potential Candidates for the EU Membership. Sustainability 2019, 11, 1528. [CrossRef]

27. Štreimikienė, D.; Balezentis, T. Kaya identity for analysis of the main drivers of ghg emissions and feasibility to implement eu "20-20-20" targets in the Baltic states. Renew. Sustain. Energy Rev. 2016, 58, 1108-1113. [CrossRef]

28. Liobikienè, G.; Butkus, M. The European union possibilities to achieve targets of Europe 2020 and paris agreement climate policy. Renew. Energy 2017, 106, 298-309. [CrossRef]

29. D'Adamo, I.; Rosa, P. Current state of renewable energies performances in the European union: A new reference framework. Energy Convers. Manag. 2016, 121, 84-92. [CrossRef]

30. Capros, P.; Paroussos, L.; Fragkos, P.; Tsani, S.; Boitier, B.; Wagner, F.; Busch, S.; Resch, G.; Blesl, M.; Bollen, J. Description of models and scenarios used to assess European decarbonisation pathways. Energy Strategy Rev. 2014, 2, 220-230. [CrossRef]

31. Lund, H. Renewable energy strategies for sustainable development. Energy 2007, 32, 912-919. [CrossRef]

32. Resch, G.; Gephart, M.; Steinhilber, S.; Klessmann, C.; del Rio, P.; Ragwitz, M. Coordination or harmonisation? Feasible pathways for a European res strategy beyond 2020. Energy Environ. 2013, 24, 147-170. [CrossRef]

33. Klessmann, C.; Rathmann, M.; de Jager, D.; Gazzo, A.; Resch, G.; Busch, S.; Ragwitz, M. Policy options for reducing the costs of reaching the European renewables target. Renew. Energy 2013, 57, 390-403. [CrossRef]

34. Markaki, M.; Belegri-Roboli, A.; Sarafidis, $\Upsilon$.; Mirasgedis, S. The carbon footprint of Greek households (1995-2012). Energy Policy 2017, 100, 206-215. [CrossRef]

35. Eurostat. Energy from Renewable Sources (Summary-Results-Shares-2014). Available online: http://ec. Europa.Eu/eurostat/web/energy/data/shares (accessed on 5 February 2016).

36. Rezitis, A.N.; Ahammad, S.M. The relationship between energy consumption and economic growth in South and Southeast Asian countries: A panel vector autoregression approach and causality analysis. Int. J. Energy Econ. Policy 2015, 5, 704-715. [CrossRef]

37. Fumon, N.; Biswas, M.A.R. Regression analysis for prediction of residential energy consumption. Renew. Sustain. Energy Rev. 2015, 47, 332-343. [CrossRef]

38. Salim, R.A.; Shafiei, S. Urbanization and renewable and non-renewable energy consumption in OECD countries: An empirical analysis. Econ. Model. 2014, 38, 581-591. [CrossRef]

39. Anwar, A.; Arshed, N.; Kousar, N. Renewable Energy Consumption and Economic Growth in Member of OIC Countries. Eur. Online J. Nat. Soc. Sci. 2017, 6, 111-129. [CrossRef]

40. Liu, Y. Exploring the relationship between urbanization and energy consumption in China using ARDL (autoregressive distributed lag) and FDM (factor decomposition model). Energy 2009, 34, 1846-1854. [CrossRef]

41. Tzeng, G.H.; Shiau, T.A.; Lin, C.Y. Application of multicriteria decision making to the evaluation of new energy system development in Taiwan. Energy 1992, 17, 983-992. [CrossRef]

42. Sadorsky, P. Renewable energy consumption and income in emerging economies. Energy policy 2009, 37, 4021-4028. [CrossRef]

43. Pappas, S.S.; Ekonomou, L.; Karamousantas, D.C.; Chatzarakis, G.; Katsikas, S.; Liatsis, P. Electricity demand loads modeling using AutoRegressive Moving Average (ARMA) models. Energy 2008, 33, 1353-1360. [CrossRef]

44. Ozturk, S.; Ozturk, F. Forecasting Energy Consumption of Turkey by Arima Model. J. Asian Sci. Res. 2018, 8, 52-60. [CrossRef]

45. Barak, S.; Sadegh, S. Forecasting energy consumption using ensemble ARIMA-ANFIS hybrid algorithm. Electr. Power Energy Syst. 2016, 82, 92-104. [CrossRef] 
46. Yuan, C.; Liu, S.; Fang, Z. Comparison of China's primary energy consumption forecasting by using ARIMA (the autoregressive integrated moving average) model and GM(1,1) model. Energy 2016, 100, 384-390. [CrossRef]

47. Tsai, S.B.; Xue, Y.; Zang, J.; Chen, Q.; Liu, Y.; Zhou, J.; Dong, W. Models for forecasting growth trends in renewable energy. Renew. Sustain. Energy Rev. 2017, 77, 1169-1178. [CrossRef]

48. Tvaronavičienè, M.; Prakapienè, D.; Garškaitè-Milvydienė, K.; Prakapas, R.; Nawrot, Ł. Energy Efficiency in the Long-Run in the Selected European Countries. Econ. Sociol. 2018, 11, 245-254. [CrossRef] [PubMed]

49. Shindina, T.; Streimikis, J.; Sukhareva, Y.; Nawrot, Ł. Social and Economic Properties of the Energy Markets. Econ. Sociol. 2018, 11, 334-344. [CrossRef]

50. Rabe, M.; Streimikiene, D.; Bilan, Y. The Concept of Risk and Possibilities of Application of Mathematical Methods in Supporting Decision Making for Sustainable Energy Development. Sustainability 2019, 11, 1018. [CrossRef]

51. Würzburg, K.; Labandeira, X.; Linares, P. Renewable generation and electricity prices: Taking stock and new evidence for Germany and Austria. Energy Econ. 2013, 40, 159-171. [CrossRef]

52. Rubins, M.; Pilvere, I. Development of renewable energy policy in Latvia. In Proceedings of the 2017 International Conference "ECONOMIC SCIENCE FOR RURAL DEVELOPMENT", Jelgava, Latvia, 27-28 April 2017.

53. Blecich, P.; Petrić, M.; Franković, B. Renewable energy in Croatia: A review of present state and future development. In Proceedings of the 11th ISES Eurosun Conference, Palma, Spain, 11-14 October 2016.

54. Proença, S.; Aubyn, M.S. Hybrid modeling to support energy-climate policy: Effects of feed-in tariffs to promote renewable energy in Portugal. Energy Econ. 2013, 38, 176-185. [CrossRef]

55. Lund, H.; Mathiesen, B.V. Energy system analysis of $100 \%$ renewable energy systems-The case of Denmark in years 2030 and 2050. Energy 2009, 34, 524-531. [CrossRef]

56. Chirila, N. Renewable Energy in Romania; Flanders Investment \& Trade: Brussels, Belgium, 2013; pp. 1-56.

57. Streimikiene, D.; Simionescu, M.; Bilan, Y. The Impact of Biodiesel Consumption by Transport on Economic Growth in the European Union. Eng. Econ. 2019, 30, 50-58. [CrossRef]

58. ŠtreimikienėD Kasperowicz, R. Economic growth and energy consumption: Comparative analysis of V4 and the "old" EU countries. J. Inter. Stud. 2016, 9, 181-194. [CrossRef]

59. Stavytskyy, A.; Kharlamova, G.; Giedraitis, V.; Šumskis, V. Estimating the interrelation between energy security and macroeconomic factors in European countries. J. Inter. Stud. 2018, 11, 217-238. [CrossRef] [PubMed]

60. Simionescu, M.; Albu, L.L.; Raileanu Szeles, M.; Bilan, Y. The impact of biofuels utilisation in transport on the sustainable development in the European Union. Technol. Econ. Develop. Econ. 2017, 23, 667-686. [CrossRef]

61. Soava, G.; Mehedintu, A.; Sterpu, M.; Raduteanu, M. Impact of renewable energy consumption on economic growth: Evidence from European Union countries. Technol. Econ. Develop. Econ. 2018, 24, 914-932. [CrossRef]

62. Zhao, H.; Guo, S. External Benefit Evaluation of Renewable Energy Power in China for Sustainability. Sustainability 2015, 7, 4783-4805. [CrossRef]

63. Ntanos, S.; Skordoulis, M.; Kyriakopoulos, G.; Arabatzis, G.; Chalikias, M.; Galatsidas, S.; Batzios, A.; Katsarou, A. Renewable Energy and Economic Growth: Evidence from European Countries. Sustainability 2018, 10, 2626. [CrossRef]

64. Temiz Dinç, D.; Akdoğan, E.C. Renewable Energy Production, Energy Consumption and Sustainable Economic Growth in Turkey: A VECM Approach. Sustainability 2019, 11, 1273. [CrossRef]

65. Singh, N.; Nyuur, R.; Richmond, B. Renewable Energy Development as a Driver of Economic Growth: Evidence from Multivariate Panel Data Analysis. Sustainability 2019, 11, 2418. [CrossRef]

66. Alper, A.; Oguz, O. The role of renewable energy consumption in economic growth: Evidence from asymmetric causality. Renew. Sustain. Energy Rev. 2016, 60, 953-959. [CrossRef]

67. Gasparatos, A.; Doll, C.N.H.; Esteban, M.; Ahmed, A.; Olang, T.A. Renewable energy and biodiversity: Implications for transitioning to a Green Economy. Renew. Sustain. Energy Rev. 2017, 70, 161-184. [CrossRef]

68. Inglesi-Lotz, R. The impact of renewable energy consumption to economic growth: A panel data application. Energy Econ. 2016, 53, 58-63. [CrossRef]

69. Yan, Q.; Wan, Y.; Mikalauskas, I.; Mikalauskiene, A. Smart Grids for Renewable Energy: Costs and Benefits. Transform. Bus. Econ. 2017, 16, 430-440. 
70. Chang, M.-C.; Shieh, H.-S. The Relations between Energy Efficiency and GDP in the Baltic Sea Region and Non-Baltic Sea Region. Transform. Bus. Econ. 2017, 16, 235-248.

71. Chen, J.; Cheng, S.; Nikic, V.; Song, M. Quo Vadis? Major Players in Global Coal Consumption and Emissions Reduction. Transform. Bus. Econ. 2018, 17, 112-133.

(c) (1) BY

(C) 2019 by the authors. Licensee MDPI, Basel, Switzerland. This article is an open access article distributed under the terms and conditions of the Creative Commons Attribution (CC BY) license (http://creativecommons.org/licenses/by/4.0/). 

Article

\title{
Assessing Business Risks of Natural Gas Trading Companies: Evidence from GET Baltic
}

\author{
Mangirdas Morkunas *, Gintaras Cernius and Gintare Giriuniene \\ Faculty of Economics and Business, Mykolas Romeris University, Ateities str. 20, Vilnius 08303, Lithuania \\ * Correspondence: morkunas.mangirdas@mruni.eu
}

Received: 5 June 2019; Accepted: 8 July 2019; Published: 10 July 2019

\begin{abstract}
The aim of this research is to distinguish business risks that affect natural gas trading companies operating in the liberalized natural gas market and to assess them according to the potential impact on the aforementioned gas trading companies. To achieve this, a study of international scientific literature and empirical research was conducted, as well as the methods of expert survey, Analytical Hierarchy Process with different measurement scales and logical investigation. The research of the business risks of natural gas trading companies reflected that natural gas trading companies in the liberalized market distinguish in significantly different business risks' portfolios from those that operate under monopoly conditions. It was also found that it is difficult to evaluate the business risks' importance for the natural gas trading companies acting in liberalized markets because they characterize in a hierarchical structure, which means that they are prone to cascading effects.
\end{abstract}

Keywords: business risks; gas trading companies; liberalized energy market; analytical hierarchy process (AHP)

\section{Introduction}

The main determinants of the structure of Central European markets were formed in the first 10-15 years after the collapse of the Socialist system [1]. Then an intensive reorganization of economic-commercial relations based on central planning into a multi-level, free, dynamic, supply-demand mechanism-driven platform for satisfying social, economic and cultural needs was ongoing. Formation of market relations requires innovative transformation of the economic structure associated to the comprehensive reorganization of economic mechanisms, commercial ideology and economic relations. Unfortunately, the energy sector was lagging behind these structural changes and remained largely intact in its primary monopolized form till the new European Union (EU) Third Legislative package was implemented. The electricity market was the first to be liberalized with the gas sector in some New EU Member Countries remaining in a shadow of ongoing liberalization processes [2]. The opening of markets not only creates possibilities for business development, but also leads to the emergence of new sorts of risks, with which market players do not always have the experience to deal with. They were distinguished in the scientific literature, which analyzed business risks in Western energy markets. A focus on price differences has been highlighted by Dahlgren et al. [3] when assessing business risks of energy trading companies. Al-Awami and Sortomme [4] put emphasis on the capacity of the energy transmission grid as a physical bottleneck for providing energy commodities. Wang et al. [5] deeply analyzed the possibility of lowering the operational amount of business risks of energy trading companies by precisely forecasting the consumption timing, thus once again stressing the importance of this business risk in energy trading companies risk portfolios. Implementing smart grids as a solution for operational amounts of risk management was analyzed by Tushar et al. [6], although stressing possible negative consequences of this decision, such as price discrimination. The proper price risk management is a focal point in James' study [7], who argues that it is the most important business 
risk of energy trading companies, which may determine the whole existence of such business entities. Although there are attempts to classify energy trading companies in the same group as ones dealing with financial derivatives trading [8], and proposing to analyze them in one group, Parashchiv [9] documents a fundamental differences in risk portfolios of these business entities (mainly associated with energy production, storage and transmission processes), proving unsoundness of this scientific approach. A blockchain technology is proposed as a solution for precise forecasting of energy demand by Mengelkamp et al. [10], also this technology displays drawbacks then facing hardly predictable consumer behavior [11]. This obstacle for precise forecasting of energy demand has been researched by Haas et al. [12] and Dianshu et al. [13]. The very low margin, which is acceptable in differences in price for energy commodities provided by different suppliers, was documented by Bohi [14], who stresses the homogeneity of this product, the fact which determines that difference in prices of different providers can be no bigger than costs associated with the change of the supplier, which in liberalized markets are very low. New arising energy trading companies risks, associated with peer-to-peer energy trading, stimulated by the growth of alternative energy production, are mentioned by Li et al. [15].

These business risks are a particularly new reality to states, which have only recently opened their energy markets shifting from monopolized and regulated to free supply-demand mechanism-driven market structure and are in the future for Eastern Europe [16]. Here, due to the need of significant input of primary investments and long capital's payback period, the economic experts assumed the energy sector as a natural monopoly to be regulated, in which competitiveness and the entrepreneurial activity and efficiency it stimulates, as well as pressure for the final price of the product and openness of the market, seemed impossible $[17,18]$. However, lately this attitude is shifting rapidly. This is due to the implementation of the EU Third Energy legislative Package (Directive EC 2009/73), which is aimed at creating a secure, transparent, market-oriented common European energy market without energy islands $[19,20]$. The Directive divided the previously-existing natural monopoly into separate owners of natural gas supply and distribution infrastructures independent of one another and natural gas supply (trade) companies, and created a transparent, competitive natural gas trade market controlled by demand-supply balance. The implementation of these legal requirements start showing positive results in formerly monopolized markets. In Lithuania, which started to implement the requirements of this document in 2014 and finished in 2016, it allowed to introduce new suppliers to the market (through LNG terminal which became rational and viable only after implementation of core principles of the Third Energy legislative Package), made a negotiating position of Lithuanian energy suppliers more firm, and created conditions for emergence of gas trading companies, which, in sum, allowed for the reduction of the final price of natural gas for the consumers of Lithuania by 30 percent. However, markets and market players, used to operating in regulated and predictable monopolized markets, faced the new reality of liberalized markets and are prone to various challenges and risks. New market regulation mechanisms must be created; new ways of conducting business appear [21]. One such phenomena is the emergence of particularly new business entities, such as gas trading companies. In this article we examine the business risks faced by gas trading companies in a newly liberalized energy market. The aim of this study is to distinguish business risks that affect natural gas trading companies operating in the liberalized natural gas market and to assess them according to the potential impact on the aforementioned gas trading companies. The empirical base is a first energy market in the Baltic States: GET Baltic and the companies operating there. We employed expert interviews and an Analytical Hierarchy Process method with adaptive, balanced and Koczkodaj scales in order to get the results.

The study complements the existing stream of scientific literature aimed at evaluating business risks in immature markets [22-24], liberalization of energy markets [25-27] and energy trading [28-30].

\section{The Concept of Business Risk}

The scientific approach to risk is being reflected in two different ways: risk is understood as a threat or indefiniteness. Risk as a threat is perceived as a possibility for "the unpredicted events to happen, 
and the likely events not, if in any mentioned case an unfavorable result is being conditioned" [31,32]. Risk expresses a threat to business goals by a constantly changing environment [33]; it can also be defined as a positive or negative variable's deviation from its plausible value [34,35] and often, in practice, it is a negative result. The research on business risks highlight immeasurability, which can influence the agent during part of or the entire period of its activity [36]. Business risk is also viewed as "a problem that has not yet occurred" [37]. Similarly, it can be assessed as a certain situation when a possibility for an unfavorable deviation from a preconceived goal appears [38]. Another way to study business risks is from a prism of possibilities [39]. Under this perspective, a risk is perceived as an obligatory activity in undefined circumstances, during which the probability arises for not achieving the expected result, or a likelihood for failure or deviation from the goal, and the comprehension of which highly depends on circumstances; nevertheless, a risk could also manifest as an unpredicted benefit. Therefore, a risk involves a chance of a particular winning, as it can be "a possibility of danger, losses or income" [40]. Almost all definitions of risk in scientific literature distinguish two elements: uncertainty (or probability of coincidence) and losses (negative outcome), which are related with an unpredicted event. However, the risk itself consists of three main components: events that the company sought to avoid, but which nevertheless occurred, the likelihood of those events and the assessment of awaited causal actions. The scientific literature suggests that there is a link between indefiniteness and risk [41,42], since risk itself is indefiniteness [43]. However, there is also some criticism regarding this approach, because risks are both known and unknown (undefined), while indefiniteness is a wider concept [44]. Additionally, a risk can be viewed as uncertainty and unwanted difficulties that arise due to the operated activity [45]. Therefore, business risk is an opportunity for inaccuracy, meaning that the achieved results shall deviate from the pursued goal [17]. In fact, both internal and external environments of the business enterprise are prompting the risk, and the entire activity of the organization is related to risk and its manifestation [43]. Nevertheless, one feature of business risk is evident in the definitions given by the majority of scholars; therefore, a generalization emerges which claims a risk to be the future result of present actions [46].

\section{Business Risks in the Natural Gas Trade}

Natural gas trading companies are subject to a wide variety of business risks. Some scholars suggest considering energy commodities trader business risks as starting from product competition risk [47-49]. Natural gas as an energy commodity in the retail consumption market competes with fuel oil and biofuel (in manufacturing and heat production) [50], electricity, liquefied petroleum gas, diesel fuel (in industry), firewood, coal, peat, geothermal energy (in household heat production) and the like. Therefore, with the increase in the demand of one of the competing commodities, the decrease in natural gas demand is probable. This could happen if competitive energy commodities grow significantly cheaper. It is worth mentioning that in order to shift to a different type of fuel, a sustained essential change in the price of the energy commodity is necessary, as it is necessary to make certain capital investments (replacing devices, furnaces and the like). The competitiveness of natural gas can be affected by a significant increase in prices, change in environmental standards or development of an alternative energy [51,52]. The latter two factors could be induced by certain state actions in the pursuance of energy security [53], shift in industry structure, or state prestige on the international level. The risk of over-regulation can also manifest itself through the shifting of market conjuncture. Personnel risk (encompassing the incompetency or negligence of personnel, dishonest and unlawful acts and similar issues related to human resources) [45] is a characteristic of all companies without exception, given there is more than one employee in the organization. As a result, manifestation of the mentioned risk and the hazard it causes is also plausible in natural gas trading companies, which in turn conditions three more risks to natural gas trading activities. Technological risk (or risk for technical breakdowns) is one of them [54]. Even though natural gas trading companies do not exploit the main or distribution gas pipes and do not have the right to control them (this is prohibited by the EU Third Energy Legislative Package), any defect of gas supply infrastructure reduces the 
physical possibility of accessing the commodity [55]. Moreover, the employees of a natural gas trading company indirectly (due to false balancing data) can influence the trustworthiness of physical natural gas trade infrastructure. As a result, any type of technical breakdown can cause detriment to the property, health or even lives of the third parties [56]. This can lead to litigation risk [56,57], the consequences of which cannot be precisely foreseen, because there is no legal practice for investigating such detriments established so far. Therefore, it can be stated that a probability to incur extremely significant financial losses exists. Dishonest personnel actions can directly cause risks of legal actions regarding unfulfilled contract clauses or unfair speculative trade. Incompetency of personnel also can condition volume risk [58-60], which is one of the essentials in the natural gas trading activity. Briefly, it can be described as potential financial losses, which are caused by the imprecise calculation of natural gas demand. If, under a long-term contract, a company purchases an insufficient amount of natural gas than is necessary for the satisfaction of customer needs, to meet the demand it has to purchase a certain additional amount of gas in the spot market, i.e., at a higher cost [61]. Unwilling to lose it clients, the company has to sell the gas at an agreed (or established on the market) price, i.e., at a lower profit margin. If the amount purchased in the spot market is significant, the company might become detrimental to trade it or fall short in working capital for purchasing it. If a company purchases too much natural gas under a long-term contract and has nowhere to realize it, it has to follow the provision "take-or-pay" and pay the provider forfeit, and as a result, experience financial losses [62]. Reputation risk is rather widely studied in scientific literature [63-65]; therefore, it shall not be elaborated. Risk of customers' default [44] may cause the volume risk, because upon the bankruptcy (or failure to fulfil one's contract obligations) of several larger clients, the company might face the aforementioned situation. Besides, it would also condition credit risk, since in order to continue one's activity the working capital would have to be borrowed. Credit risk [66-68] also emerges due to the intensifying competition between the companies. In order to maintain and attract customers, they not only have to reduce the sale prices, but also extend the term for payment deferral; this can lead to the situation where a company has to pay for the purchased production prior to its receiving the money for the volume sold [69]. This risk assumes the greater likelihood of the event, the greater the quantity of natural gas is being purchased in the spot market. Risk of supplier default [70] is essential because given a gas trading company, being in a long-term contract, fails to receive the commodity due to some reasons (technical, political, economic, etc.), all of the production would have to be purchased in the spot market. Obviously, this would not allow trading at the agreed-upon (or established) price on the internal state's market; the company would lose its customers, which, ultimately, would lead the company to bankruptcy [71,72]. As any other company that has economic interests in more than one country which is not a monetary union ally, natural gas trading companies face monetary risk, i.e., natural gas is purchased in international payment currency (USA dollar), but sold in the country's local currency: Euros [73,74]. It is noteworthy to mention that this is more of a theoretical risk because none of the natural gas supplying companies operating in the GET Baltic market take the risk directly on themselves, but rather impose it to the insurance companies. Purchase price risk is directly affecting the commodity price risk, since the profit margin of a gas trading company basically amounts to the difference between production selling and purchase prices. Systematized business risks affecting the natural gas trading companies are presented in Table 1. 
Table 1. Business risks affecting natural gas trading companies.

\begin{tabular}{cc}
\hline Type of Business Risk & Result of Manifestation \\
\hline Product competition risk & $\begin{array}{c}\text { Competitive/alternative energy carriers become more attractive to } \\
\text { consumers than natural gas. }\end{array}$ \\
\hline Risk of changes in environmental standards & Loss of potential or present consumers. \\
\hline Alternative energy risk & Intensified competition, potential loss of part of consumers. \\
\hline Risk of over-regulation & $\begin{array}{c}\text { Economically unfounded intervention actions of state institutions to } \\
\text { the energy carrier market, pursuing political interest. }\end{array}$ \\
\hline Personnel risk & $\begin{array}{c}\text { Speculative trading, submission of false balancing data and other } \\
\text { consequences potentially caused by company's personnel actions. }\end{array}$ \\
\hline Technological risk & $\begin{array}{c}\text { Performance malfunction of physical natural gas supply } \\
\text { infrastructure. }\end{array}$ \\
\hline Litigation risk & $\begin{array}{c}\text { Obligation to make amends for extensive detriment; temporal } \\
\text { security measures applied during litigation process, etc. }\end{array}$ \\
\hline Operating volume risk & $\begin{array}{c}\text { Necessity to purchase the commodity at a higher cost or execution of } \\
\text { "take-or-pay" provision. }\end{array}$ \\
\hline Reputation risk & Consumers' approval of competing companies. \\
\hline Risk of customers' default & Absence of possibility to sell the purchased quantity of production. \\
\hline Risk of supplier default & Absence of possibility to purchase commodity for resale. \\
\hline Reserves value risk & Potential decrease in value of the commodity purchased for resale. \\
\hline Currency risk & $\begin{array}{c}\text { Increase or decrease in commodity price due to currency } \\
\text { fluctuations. }\end{array}$ \\
\hline Commodity price risk & $\begin{array}{c}\text { The commodity becomes too expensive for potential consumers or } \\
\text { too expensive in respect to competitive products. }\end{array}$ \\
\hline Risk of changes in tax codes & $\begin{array}{c}\text { Additionally taxed consumption of fossil fuel or granted tax } \\
\text { concessions for the development of alternative energy carriers. }\end{array}$ \\
\hline
\end{tabular}

The whole risk portfolio of gas trading companies operating in liberalized markets is reflected in Figure 1:

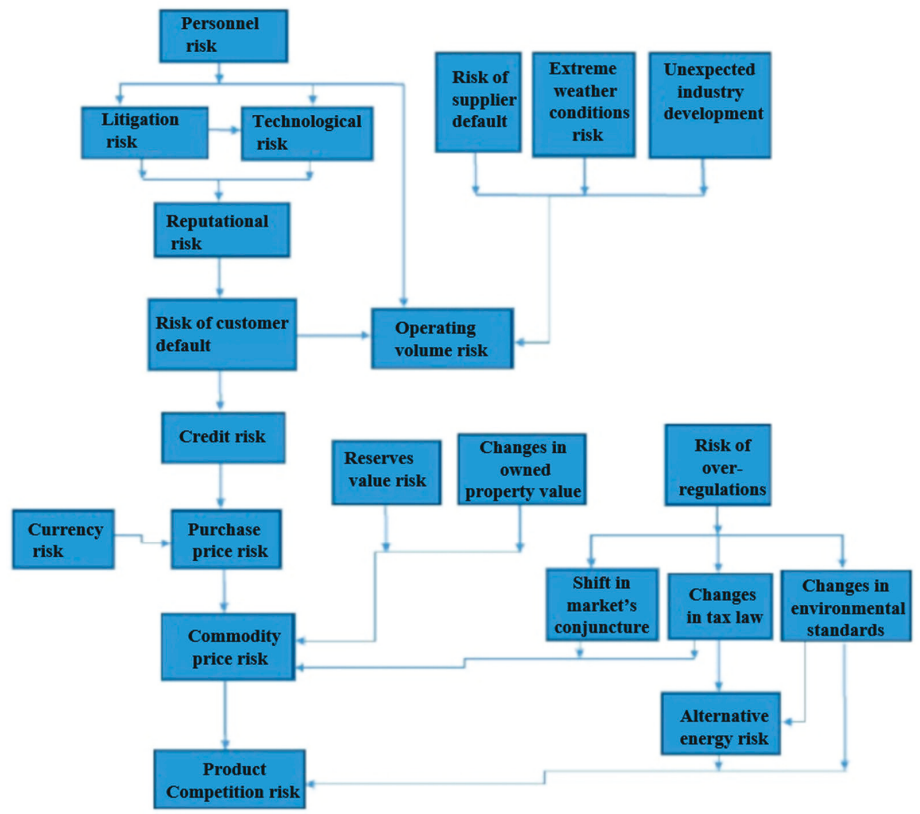

Figure 1. The risk map of gas trading companies. Source: own work. 
As can be seen from the table and figure above, the majority of researched risks affecting natural gas trading companies are interrelated and can cause a chain reaction of the risks. This makes the evaluation of risks rather complicated and raises additional challenges in selecting research methods [75]. Nevertheless, it is necessary to choose the methods that would also allow assessing the hierarchical dependency of the risks that affect natural gas trading companies. The solution for this challenge is presented in the methodological section of this research paper.

\section{Methodology}

In order to decide which business risks are the most important to natural gas trading companies, we employed an expert survey. The obtained results were processed by applying the Analytic Hierarchy Process (AHP) model, which is highly recommended for solving complex, interconnected, hierarchical problems that cannot be solved using purely quantitative methods [76]. Initially, more than ten business risks were identified during the scientific literature analysis, which is more than the maximum number of alternatives that AHP is capable of processing. Therefore, we performed an initial survey, during which we eliminated the less important business risks (according to the potential impact on a gas trading company) and identified nine of the most significant business risks, which were the subject of our research: operating volume risk, purchase price risk, product competition risk, alternative energy risk, risk of customers' default, risk of supplier default, technological risk, reputation risk, and personnel risk.

In the pursuance of obtaining more reliable results and following the principle of triangulation, we employed three different scales of an AHP: balanced, Koczkodaj and adaptive, representing all three scale groups. After obtaining the results of each scale, the eigenvector of each risk was normalized.

GET Baltic has 77 registered natural gas trading companies, though four of the biggest market players control over 87\% [77] of the market share. In 2018, GET Baltic was responsible for $15.3 \%$ of all natural gas sold in Lithuania. Lithuanian gas trading companies received more than $130 \mathrm{mln}$. EUR of revenues from gas retailing in a first half of 2018, showing an increase of $6.5 \%$ compared to the first half of 2017 [77].

The following criteria were employed for selecting the experts: (a) all biggest market players must be represented in a survey; (b) at least $10 \%$ of the rest natural gas trading companies, registered in GET Baltic, must be represented in the survey; (c) the expert must hold a Master of Science or equal degree (in fact, all the respondents hold a Master of Science; no MBAs or similar degree holders participated in the survey), have at least 5 years of experience in gas trading business sector and occupy a position no lower than manager. In total, 12 experts participated in our survey.

In AHP, the chosen experts evaluated the presented alternatives (business risks of natural gas trading companies) $\left\{\theta_{-} 1, \ldots, \theta_{-} n\right\}$, by filling individual pairwise comparison matrices, which were being calculated as follows:

$$
\mathbf{M}=\left(\begin{array}{cccc}
\frac{m_{1}}{m_{1}} & \frac{m_{1}}{m_{2}} & & \frac{\frac{m_{1}}{m_{n}}}{m_{2}} \\
\frac{m_{2}}{m_{2}} & \ldots & \frac{m_{2}}{m_{n}} \\
\frac{m_{n}}{m_{1}} & \frac{m_{n}}{m_{2}} & & \frac{m_{n}}{m_{n}}
\end{array}\right)=\left(\begin{array}{lll}
b_{11} & b_{12} \ldots & b_{1 n} \\
b_{12} & b_{21} \ldots & b_{2 n} \\
b_{n 1} & b_{n 2} \ldots & b_{n n}
\end{array}\right) ;
$$

Here: $b_{i j}$-Pairwise comparison matrix element; $\frac{m_{i}}{m_{j}}-$ A priority vector of the $i$-th factor with the respect to $j$-th factor.

$$
m_{i j}=\frac{1}{m_{j i}}, \forall i, j=1,2, \ldots, n .
$$

After the experts made a pairwise comparison of the criteria presented, all responses (evaluations) were recorded in the form of standardized matrices. 
A multiplication of the $i$-th line elements was being computed to every $M$ matrix:

$$
\Pi_{i}=\Pi_{j=1}^{n} m_{i j},(i=1, \ldots, n) .
$$

The obtained values were being normalized using the formula:

$$
k_{i}=\frac{\sqrt[n]{\Pi_{i}}}{\sum_{i=1}^{n} \sqrt[n]{\Pi_{i}}}=\frac{\sqrt[n]{\Pi_{j=1^{a_{i j}}}^{n}}}{\sum_{i=1}^{n} \sqrt[n]{\Pi_{j=p^{a_{i j}}}^{n}}},\left(i=1, \ldots, n ; \sum k_{1}=1\right)
$$

A priority rank of each expert was obtained in such a way. After that, a procedure of consistency of matrices was being undertaken. Matrix was considered consistent, when $m_{i k}=m_{i j} m_{j k}, \forall i, j, k$ and a priority vector was existent, which satisfied the equation: $w=\left(\omega_{1}, \ldots, \omega_{n}\right)$, where $m_{i j}=\frac{\omega_{i}}{\omega_{j}}, \forall i, j$.

After that, the consistency index (CI) of each standardized matrix was being calculated. In order to obtain $\mathrm{CI}$, an eigenvalue $\left(\lambda_{\max }\right)$ of each standardized matrix was calculated using formula:

$$
\lambda_{\max }=\sum_{j=1}^{n} \frac{(\mathrm{P} \cdot v)_{j}}{n \cdot v_{j}} .
$$

Here $\lambda_{\max }$-the largest eigenvalue of each research standardized matrix; $n-$ Number of independent rows in matrix; $j$-Eigenvalue of a matrix. All these steps were represented in $M_{q}$ matrix:

$$
M_{q}=\begin{array}{lll}
b_{11} & b_{12} \ldots & b_{1 n} \\
b_{12} & b_{21} \ldots & b_{2 m} \\
b_{n 1} & b_{n 2} \ldots & b_{n n}
\end{array}\left(\begin{array}{c}
q_{1} \\
q_{2} \\
q_{n}
\end{array}\right)=\left(\begin{array}{ccc}
b_{11} q_{1}+ & b_{12} q_{2}+\cdots & +b_{1 n} q_{n} \\
b_{12} q_{1}+ & b_{21} q_{2}+\cdots & +b_{2 n} q_{n} \\
b_{m 1} q_{1}+ & b_{m 2} q_{2}+\cdots & +b_{n n} q_{n}
\end{array}\right)=\lambda_{\max }\left(\begin{array}{l}
q_{1} \\
q_{2} \\
q_{n}
\end{array}\right)=\left(\begin{array}{c}
\lambda_{\max } q_{1} \\
\lambda_{\max } q_{2} \\
\lambda_{\max } q_{n}
\end{array}\right)
$$

An expert comparison matrix $M_{q}$ was considered absolutely consistent when $\lambda_{\max }=n$, although in reality it almost never happens. In the case of small $m_{i j}$ changes, matrix $M$ satisfied the pre-selected compatibility condition (in this case 0.1 was selected), the $\lambda_{\max }$ value became close to $n$.

After calculating the eigenvalue $\lambda_{\max }$, the $\mathrm{CI}$ was calculated using formula:

$$
\mathrm{CI}=\frac{\lambda_{\max }-n}{n-1} .
$$

Here $n$-number of possible alternatives.

If CI met the pre-selected compatibility condition (our case: 0.1 ), the aggregated expert evaluation was being calculated using formula [78]:

$$
p_{i j}^{P}=\sqrt[n]{p_{i j}^{1}} \times p_{i j}^{2} \times \ldots \times p_{i j}^{n}
$$

Here $p_{i j}^{A}$ - aggregated evaluation of element, belonging to $i$ row and $j$-column;

$n-$ number of matrices of the pairwise comparison of each expert.

After obtaining new aggregated matrixes, a consistency validation procedure was once again performed. If matrix was consistent, then preferred ranks of alternatives were being calculated using formula [79]:

$$
\omega_{j}=\frac{\sqrt[i]{\prod_{j=1}^{i} p_{i j}^{P}}}{\sum_{j=1}^{i} \sqrt[i]{\prod_{j=1}^{i} p_{i j}^{P}}}
$$

Here $\omega_{j}$-Weight of alternative $j$. 
In order to check, whether the experts' opinions were consistent and valid, and they actually reflected the realistic picture, the index of expert mutual agreement $\left(S^{*}\right)$ was calculated [80]:

$$
\mathrm{S}^{*}=\frac{\frac{1}{\exp \left(H_{\beta}\right)-\frac{\exp \left(H_{\alpha \min }\right)}{\exp \left(H_{\gamma \max }\right)}}}{1-\frac{\exp \left(H_{\alpha \min }\right)}{\exp \left(H_{\gamma \max }\right)}}
$$

Here $H_{\alpha}$-Shannon alpha diversity; $H_{\beta}$-Shannon beta diversity; $H_{\gamma}$-Shannon gamma diversity. Goepel's index varies between $0 \%$ and $100 \%$ and shows the agreement level of the experts involved.

After completing the survey, we noticed that two questionnaires of the survey did not meet the predefined consistency ratio of 0.1 . In order to solve this issue, we employed S-Method [81], following the steps:

o Calculation of a priority vector $\omega=\omega \_i$ using proper vector method;

o Comparison of each $P_{-} i j$ value to respective ratios of the vectors $\omega_{-} i / \omega_{-} j$;

1. Identification of element $P_{-} i j$, which makes the most influence on the inconsistency among experts' views, and its modification to $\omega_{-} i / \omega_{-} j$;

o Identification of the priority values of the modified matrix.

Only after these steps can the results be considered robust and be analyzed further.

\section{Results and Discussion}

The calculated aggregated index of expert mutual agreement $S^{*}$ equals to 0.64631 , meaning that the level of expert compatibility is $65 \%$. Such a result corresponds to the requirements of the data reliability for scientific articles; therefore, expert evaluation is acknowledged to be appropriate and the conclusions based on them are reliable. After additional procedures were taken to increase compatibility, all of the surveys were recognized as acceptable and eigenvectors of each business risk were calculated applying balanced, Koczkodaj and adaptive scales. The achieved results are presented in Table 2.

Table 2. Results of ranking the risk.

\begin{tabular}{cccccc}
\hline Business Risk & $\begin{array}{c}\text { Eigenvector } \\
\text { Obtained } \\
\text { Using } \\
\text { Balanced Scale }\end{array}$ & $\begin{array}{c}\text { Eigenvector } \\
\text { Obtained Using } \\
\text { Koczkodaj Scale }\end{array}$ & $\begin{array}{c}\text { Eigenvector } \\
\text { Obtained } \\
\text { Using } \\
\text { Adaptive Scale }\end{array}$ & $\begin{array}{c}\text { Normalized } \\
\text { Eigen Vector }\end{array}$ & Rank \\
\hline $\begin{array}{c}\text { Alternative energy risk } \\
\text { Operating volume risk }\end{array}$ & 0.0454 & 0.0442 & 0.0428 & 0.0441 & 8 \\
$\begin{array}{c}\text { Personnel risk } \\
\text { Risk of customers' }\end{array}$ & 0.2342 & 0.2261 & 0.2438 & 0.2347 & 1 \\
$\begin{array}{c}\text { default } \\
\text { Purchase price risk }\end{array}$ & 0.1531 & 0.0949 & 0.0924 & 0.0928 & 5 \\
$\begin{array}{c}\text { Reputation risk } \\
\text { Product competition }\end{array}$ & 0.1721 & 0.1584 & 0.1532 & 0.1549 & 3 \\
$\begin{array}{c}\text { risk } \\
\text { Technological risk }\end{array}$ & 0.0751 & 0.1663 & 0.1602 & 0.1662 & 2 \\
Risk of supplier default & 0.0522 & 0.0301 & 0.0248 & 0.0253 & 9 \\
\hline
\end{tabular}

The achieved research results allow classifying business risks that affect gas trading companies into two groups: substantial risks that have a great impact on the activity of natural gas trading companies, or primary risks (i.e., operating volume risk, purchase price risk, risk of customers' default, risk of supplier default), for the management of which gas trading companies have to pay great attention; and less substantial, or secondary risks (such as personnel risk, product competition risk, technological risk, alternative energy risk, reputation risk). 
Referring to the achieved results, it becomes clear that volume risk is the most important for natural gas trading companies. Namely, in gas trading activity, extremely great attention should be given to an especially precise forecasting of the demand. It is a difficult task due to the rapidly changing climate when the average winter temperature of two years in a row in Lithuania may differ by 2.5 degrees Celsius. This affects the natural gas demand by $13 \%$, since the largest amount of natural gas, $77 \%$, is consumed in winter. Even greater fluctuations (up to $21 \%$ ) are observed when analyzing monthly consumption, which makes the prognostication of a precise operating volume even more challenging.

Second in importance is the purchase price risk. Such a high position of this risk is not surprising since gas is an especially homogeneous product, completely undistinguished in its features and sold having converted it to MWh of energy. As a result, there are no other attributes of this commodity that could portray its distinctiveness in respect to other products (such as appearance, physical features, brand, country of origin), and so it is chosen only depending on the price. Therefore, if the gas trading company purchases the product (natural gas) at a higher price than competitors in the market do, there is a great likelihood that it will lose consumers and work at a loss.

The importance of customers' default risk was likely determined by its direct role in affecting the operating volume risk, described in the theoretical section of this research paper. In fact, in pursuance of simplifying the analysis, eigenvectors of these two business risks could be summed. This would reduce the total number of business risks, as well as their interrelations, that affect natural gas trading companies.

The risk of supplier default stands in the fourth place for the gas trading companies operating in the liberalized market, whereas in non-liberalized markets it is the most important risk [70]. This is so because, given the liberalized market, in pursuance to conform to contract responsibilities, natural gas trading companies can rather promptly purchase the deficient quantity of natural gas in the spot market. In the closed natural gas market dominant by one supplier, which usually is also the owner of the natural gas supply and distribution system (i.e., if the requirements of the EU Third Energy Package are not implemented) and if the gas supplier fails in fulfilling the contract obligations, there is no possibility to purchase the lacking quantity of natural gas. This potentially determines the bankruptcy of the natural gas trading company and leaves the customers' affected. To make matters worse, this can lead to the consumers' business failure and cause a marked impairment of citizens' living conditions, given the risk manifested in winter.

Analyzing secondary risks affecting natural gas trading companies, we notice personnel risk being at the top. Even though it can cause plenty of negative outcomes to natural gas trading companies, this risk is not assessed to be very hazardous, because its manifestation to natural gas trading companies would not be direct. It cannot directly cause the risk of technology failure, since the balancing data has to be approved by the transmission system operator (in Lithuania's case, AmberGrid). The operating volume is prognosticated and approved by more than one person; therefore, this risk is assumed to be more theoretical, however, due to the damage that could be caused if it manifested, the risk is assessed to be the fifth in importance.

Product competition risk and alternative energy risk, in the context of Lithuania and other Baltic States, should be assessed jointly. Even though the product competition risk covers more factors than just the development of alternative energy (which caused its higher place on the list), it is only the development of alternative energy that can affect the competitiveness of natural gas as a commodity in the Baltic States.

Technological risk, when transmitting and distributing natural gas, is rather widely discussed in the scientific literature [82-84], thus it is perceived to be inexpedient to elaborate it in this research paper. It is noteworthy to mention that such a low importance of this risk means the market participants highly trust in the reliability of physical natural gas transportation infrastructure.

A low place of the reputation risk indicates that the company's prestige in Lithuania is not assumed to be an important part of the enterprise's intangible assets that could significantly affect the 
company's results. Such findings contradict the supposed assumptions regarding the importance of this risk in the scientific literature [85] and identify a negative aspect evidencing that the country's market is not sufficiently matured yet.

\section{Conclusions}

The results of this study reflect that natural gas trading companies in the liberalized market distinguish in significantly different business risks' portfolios from those that operate under monopoly conditions; there, the main risk concern is security of supply [86,87]. It is also difficult to evaluate the business risks' importance for the natural gas trading companies acting in liberalized markets because they characterize in hierarchical structures, which means that they are prone to cascading effects.

Nevertheless, when assessing business risks, according to the probability of their manifestation and potential damage to the gas trading company, we have identified that business risks affecting such companies can be divided into primary risks (operating volume risk, purchase price risk, risk of customers' default, risk of supplier default) and secondary risks (personnel risk, product competition risk, technological risk, alternative energy risk, reputation risk).

The essential risk for the successful activity of natural gas trading companies is distinguished to be a risk of operating volume. As a result, in order to successfully operate in the liberalized natural gas trading market, natural gas trading companies should pay especially great attention to the management and prognostication of the mentioned risk.

Author Contributions: M.M. created a research concept, theoretical background and methodology, G.C. completed survey and obtained results, G.G. drew conclusions and provided valuable comments throughout the whole document.

Funding: This research received no external funding.

Conflicts of Interest: Authors declare no conflict of interests.

\section{References}

1. Загорский, А.Л. формирование иреализация конкурентныхстратегий интегрированных бизнес-групп. Ph.D. Thesis, Российский государственный педагогический университет имА.И. Герцена, Санкт-Петрбург, Российский, 2006.

2. Costescu, A.; Manitsas, E.; Szikszai, A. State of Implementation of the Third Energy Package in the Gas Sector. JRC Science for Policy Report; Luxembourg, 2018; 130p, Available online: http://publications.jrc.ec.europa.eu/repository/bitstream/JRC110507/jrc110507_jrc110507_state_of_ implementation_3rd_energy_package_revised_by_ipo_(30.1.18)_v3.pdf (accessed on 24 June 2019).

3. Dahlgren, R.; Liu, C.C.; Lawarree, J. Risk assessment in energy trading. IEEE Trans. Power Syst. 2003, 18, 503-511. [CrossRef]

4. Al-Awami, A.T.; Sortomme, E. Coordinating vehicle-to-grid services with energy trading. IEEE Trans. Smart Grid 2011, 3, 453-462. [CrossRef]

5. Wang, Y.; Saad, W.; Han, Z.; Poor, H.V.; Başar, T. A game-theoretic approach to energy trading in the smart grid. IEEE Trans. Smart Grid 2014, 5, 1439-1450. [CrossRef]

6. Tushar, W.; Yuen, C.; Smith, D.B.; Poor, H.V. Price discrimination for energy trading in smart grid: A game theoretic approach. IEEE Trans. Smart Grid 2016, 8, 1790-1801. [CrossRef]

7. James, T. Energy Markets: Price Risk Management and Trading; John Wiley \& Sons: Hoboken, NJ, USA, 2012.

8. Huang, R.D.; Masulis, R.W.; Stoll, H.R. Energy shocks and financial markets. J. Futures Mark. Futures Options Other Deriv. Prod. 1996, 16,1-27. [CrossRef]

9. Paraschiv, F. Price dynamics in electricity markets. In Handbook of Risk Management in Energy Production and Trading; Springer: Boston, MA, USA, 2013; pp. 47-69.

10. Mengelkamp, E.; Notheisen, B.; Beer, C.; Dauer, D.; Weinhardt, C. A blockchain-based smart grid: Towards sustainable local energy markets. Comput. Sci.-Res. Dev. 2018, 33, 207-214. [CrossRef] 
11. Zipperer, A.; Aloise-Young, P.A.; Suryanarayanan, S.; Roche, R.; Earle, L.; Christensen, D.; Zimmerle, D. Electric energy management in the smart home: Perspectives on enabling technologies and consumer behavior. Proc. IEEE 2013, 101, 2397-2408. [CrossRef]

12. Haas, R.; Auer, H.; Biermayr, P. The impact of consumer behavior on residential energy demand for space heating. Energy Build. 1998, 27, 195-205. [CrossRef]

13. Dianshu, F.; Sovacool, B.K.; Vu, K.M. The barriers to energy efficiency in China: Assessing household electricity savings and consumer behavior in Liaoning Province. Energy Policy 2010, 38, 1202-1209. [CrossRef]

14. Bohi, D.R. Analyzing Demand Behavior: A Study of Energy Elasticities; RFF Press: Washington, DC, USA, 2013.

15. Li, Z.; Kang, J.; Yu, R.; Ye, D.; Deng, Q.; Zhang, Y. Consortium blockchain for secure energy trading in industrial internet of things. IEEE Trans. Ind. Inform. 2017, 14, 3690-3700. [CrossRef]

16. Proedrou, F. EU energy security beyond Ukraine: Towards holistic diversification. Eur. Foreign Aff. Rev. 2016, 21, 57-73.

17. Henderson, J.; Moe, A. Gazprom's LNG offensive: A demonstration of monopoly strength or impetus for Russian gas sector reform? Post Communist Econ. 2016, 28, 281-299. [CrossRef]

18. Bianco, V. Overview of the Italian natural gas sector. Int. J. Energy Sect. Manag. 2018, 12, 151-168. [CrossRef]

19. European Commission. Communication from the Commission to the European Parliament and the Council European Energy Security Strategy. 2014. Available online: https://eur-lex.europa.eu/legal-content/EN/ALL /?uri=CELEX:52014DC0330\&qid=1407855611566 (accessed on 20 June 2019).

20. European Commission. In-depth study of European Energy Security. 2014. Available online: https://ec.europa. eu/energy/sites/ener/files/documents/20140528_energy_security_study.pdf (accessed on 20 June 2019).

21. Carayannis, E.G.; Sindakis, S.; Walter, C. Business model innovation as lever of organizational sustainability. J. Technol. Transf. 2015, 40, 85-104. [CrossRef]

22. Aldoseri, M.; Worthington, A.C. Risk Management in Islamic Banking: An Emerging Market Imperative. In Risk Management in Emerging Markets: Issues, Framework, and Modeling; Emerald Group Publishing Limited: Bingley, UK, 2016; pp. 229-252.

23. Kim, H.; Song, J. Filling institutional voids in emerging economies: The impact of capital market development and business groups on M\&A deal abandonment. J. Int. Bus. Stud. 2017, 48, 308-323.

24. Wilson, C.; Wilson, P. Make Poverty Business: Increase Profits and Reduce Risks by Engaging with the Poor; Routledge: Abingdon, UK, 2017.

25. Vihalemm, T.; Keller, M. Consumers, citizens or citizen-consumers? Domestic users in the process of Estonian electricity market liberalization. Energy Res. Soc. Sci. 2016, 13, 38-48. [CrossRef]

26. Boersma, T.; Goldthau, A. Wither the EU's Market Making Project in Energy: From Liberalization to Securitization. In Energy Union; Palgrave Macmillan: London, UK, 2017; pp. 99-113.

27. Goldthau, A.; Sitter, N. Regulatory or market power Europe? EU leadership models for international energy governance. In New Political Economy of Energy in Europe; Palgrave Macmillan: Cham, Switzerland, 2019; pp. 27-47.

28. Liu, Y.; Zuo, K.; Liu, X.A.; Liu, J.; Kennedy, J.M. Dynamic pricing for decentralized energy trading in micro-grids. Appl. Energy 2018, 228, 689-699. [CrossRef]

29. Ma, K.; Hu, S.; Yang, J.; Dou, C.; Guerrero, J. Energy trading and pricing in microgrids with uncertain energy supply: A three-stage hierarchical game approach. Energies 2017, 10, 670. [CrossRef]

30. Zhao, N.; Fan, P.; Wu, M.; He, X.; Fan, M.; Tian, C. Dynamic Incentive Mechanism for Direct Energy Trading. In International Conference on Innovative Mobile and Internet Services in Ubiquitous Computing; Springer: Cham, Switzerland, 2018; pp. 403-411.

31. Atu, J.; Cody Morris Paris, C.M.; Marochi, B. Globalisation and health security: A case study of distant individual risk perceptions of the 2014 Ebola outbreak. J. Secur. Sustain. Issues 2018, 8, 209-220. [CrossRef]

32. Culp, C. The revolution in corporate risk management: A decade of innovations in process and products. J. Appl. Corp. Financ. 2002, 14, 8-26. [CrossRef]

33. Sadgrove, K. The Complete Guide to Business Risk Management, 3rd ed.; Routledge: New York, NY, USA, 2016; p. 578.

34. Ferreira Rebelo, M.; Silva, R.; Santos, G. The integration of standardized management systems: Managing business risk. Int. J. Qual. Reliab. Manag. 2017, 34, 395-405. [CrossRef]

35. Reason, J. Managing the Risks of Organizational Accidents; Routledge: New York, NY, USA, 2016; p. 252.

36. Christoffersen, P. Elements of Financial Risk Management; Academic Press: Waltham, MA, USA, 2011; p. 344. 
37. Hillson, D.; Murray-Webster, R. Understanding and Managing Risk Attitude; Routledge: New York, NY, USA, 2017; p. 208.

38. KarimiAzari, A.; Mousavi, N.; Mousavi, S.F.; Hosseini, S. Risk assessment model selection in construction industry. Expert Syst. Appl. 2011, 38, 9105-9111. [CrossRef]

39. Nieto-Morote, A.; Ruz-Vila, F. A fuzzy approach to construction project risk assessment. Int. J. Proj. Manag. 2011, 29, 220-231. [CrossRef]

40. Merigo, J.M. Decision-making under risk and uncertainty and its application in strategic management. J. Bus. Econ. Manag. 2015, 16, 93-116. [CrossRef]

41. Osipova, E.; Eriksson, P.E. Balancing control and flexibility in joint risk management: Lessons learned from two construction projects. Int. J. Proj. Manag. 2013, 31, 391-399. [CrossRef]

42. Aven, T. Risk assessment and risk management: Review of recent advances on their foundation. Eur. J. Oper. Res. 2016, 253, 1-13. [CrossRef]

43. Rebelo, M.F.; Santos, G.; Silva, R. Integration of management systems: Towards a sustained success and development of organizations. J. Clean. Prod. 2016, 127, 96-111. [CrossRef]

44. Kendrick, T. Identifying and Managing Project Risk: Essential Tools for Failure-Proofing Your Project; Amacom: New York, NY, USA, 2015; p. 400.

45. Aven, T. Improving risk characterisations in practical situations by highlighting knowledge aspects, with applications to risk matrices. Reliab. Eng. Syst. Saf. 2017, 167, 42-48. [CrossRef]

46. McKellar, R. A Short Guide to Political Risk; Routledge: New York, NY, USA, 2017; p. 198.

47. Arora, A.; Gambardella, A. Domestic markets and international competitiveness: Generic and product-specific competencies in the engineering sector. Strateg. Manag. J. 1997, 18, 53-74. [CrossRef]

48. Wood, D.A.; Nwaoha, C.; Towler, B.F. Gas-to-liquids (GTL): A review of an industry offering several routes for monetizing natural gas. J. Nat. Gas Sci. Eng. 2012, 9, 196-208. [CrossRef]

49. Mohseni, F.; Görling, M.; Alvfors, P. The competitiveness of synthetic natural gas as a propellant in the Swedish fuel market. Energy Policy 2013, 52, 810-818. [CrossRef]

50. Popp, J.; Kot, S.; Lakner, Z.; Oláh, J. Biofuel use: Peculiarities and implications. J. Secur. Sustain. Issues 2018, 7, 477-493. [CrossRef]

51. Melas, V.; Lisin, E.; Tvaronavičienè, M.; Peresadko, G.; Radwański, R. Energy security and economic development: Renewables and the integration of energy systems. J. Secur. Sustain. Issues 2017, 7, 133-139. [CrossRef]

52. Caporin, M.; Fontini, F. The long-run oil-natural gas price relationship and the shale gas revolution. Energy Econ. 2017, 64, 511-519. [CrossRef]

53. Tvaronavičienè, M. Towards efficient policy making: Forecasts of vulnerability to external global threats. J. Secur. Sustain. Issues 2018, 7, 591-600. [CrossRef]

54. Plèta, T.; Karasov, S.; Jakštas, T. The means to secure critical energy infrastructure in the context of hybrid warfare: The case of Ukraine. J. Secur. Sustain. Issues 2018, 7, 567-578. [CrossRef]

55. Plenkina, V.V.; Osinovskaya, I.V. Improving the system of labor incentives and stimulation in oil companies. Entrepreneurship Sustain. Issues 2018, 6, 912-926. [CrossRef]

56. Walker, T.; Turtle, H.J.; Pukthuanthong, K.; Thiengtham, D. Legal opportunism, litigation risk, and IPO underpricing. J. Bus. Res. 2015, 68, 326-340. [CrossRef]

57. Chen, C.Y. Functions of Directors' and Officers' (D\&O) Liability Insurance and Litigation Risk: An Empirical Legal Study of Taiwan. Natl. Taiwan Univ. Law Rev. 2017, 12, 1-51.

58. Xu, J.; Duan, L.; Zhang, R. Cost-aware green cellular networks with energy and communication cooperation. IEEE Commun. Mag. 2015, 53, 257-263. [CrossRef]

59. Vazquez, M.; Hallack, M. Representing the valuation of take-or-pay provisions in gas markets with limited liquidity. IEEE Trans. Power Syst. 2016, 31, 3152-3159. [CrossRef]

60. Aitzhan, N.Z.; Svetinovic, D. Security and privacy in decentralized energy trading through multi-signatures, blockchain and anonymous messaging streams. IEEE Trans. Dependable Secur. Comput. 2018, 15, 840-852. [CrossRef]

61. Masagoes, M.L. Take or pay: A different perspective? Ensuring TOP clauses always come out on top in Australia. J. World Energy Law Bus. 2017, 10, 348-357. [CrossRef]

62. Bouras, A. Using goal linear programming to manage natural gas take-or-pay contract clauses in electricity generation. J. Nat. Gas Sci. Eng. 2016, 35, 1228-1238. [CrossRef] 
63. Gatzert, N.; Schmit, J.T.; Kolb, A. Assessing the risks of insuring reputation risk. J. Risk Insur. 2016, 83, 641-679. [CrossRef]

64. Heidinger, D.; Gatzert, N. Awareness, determinants and value of reputation risk management: Empirical evidence from the banking and insurance industry. J. Bank. Financ. 2016, 91, 106-118. [CrossRef]

65. Eckert, C. Corporate reputation and reputation risk: Definition and measurement from a (risk) management perspective. J. Risk Financ. 2017, 18, 145-158. [CrossRef]

66. Bedendo, M.; Colla, P. Sovereign and corporate credit risk: Evidence from the Eurozone. J. Corp. Financ. 2015, 33, 34-52. [CrossRef]

67. Bluhm, C.; Overbeck, L.; Wagner, C. Introduction to Credit Risk Modeling; Chapman and Hall/CRC: Boca Raton, FL, USA, 2016; p. 384.

68. Chaibi, H.; Ftiti, Z. Credit risk determinants: Evidence from a cross-country study. Res. Int. Bus. Financ. 2015, 33, 1-16. [CrossRef]

69. Seifert, D.; Seifert, R.W.; Isaksson, O.H. A test of inventory models with permissible delay in payment. Int. J. Prod. Res. 2017, 55, 1117-1128. [CrossRef]

70. Allevi, E.; Boffino, L.; De Giuli, M.E.; Oggioni, G. Evaluating the impacts of the external supply risk in a natural gas supply chain: The case of the Italian market. J. Glob. Optim. 2018, 70, 347-384. [CrossRef]

71. Prusak, B. Predicting corporate bankruptcies in Poland and Lithuania-comparative analysis. Intellect. Econ. 2017, 11, 18-31.

72. Mackevičius, J.; Šneidere, R.; Tamulevičienè, D. The waves of enterprises bankruptcy and the factors that determine them: The case of Latvia and Lithuania. Entrepreneurship Sustain. Issues 2018, 6, 100-114. [CrossRef]

73. Colacito, R.; Croce, M.M.; Gavazzoni, F.; Ready, R. Currency risk factors in a recursive multicountry economy. J. Financ. 2018, 73, 2719-2756. [CrossRef]

74. Kim, S.F.; Chance, D.M. An empirical analysis of corporate currency risk management policies and practices. Pac. Basin Financ. J. 2018, 47, 109-128. [CrossRef]

75. Hudáková, M.; Dvorský, J. Assessing the risks and their sources in dependence on the rate of implementing the risk management process in the SMEs. Equilib. Q. J. Econ. Econ. Policy 2018, 13, 543-567. [CrossRef]

76. Saaty, T.L. Analytic hierarchy process. Encycl. Oper. Res. Manag. Sci. 2013, 1, 52-64.

77. Lithuania's National Commission for Energy and Price Regulation. Gamtiniu Dujų Rinkos Stebèsenos Ataskaita Už 2018 M. I PUSMET.I. 2019. Available online: http://www.vkekk.lt/SiteAssets/naujienu-medziag a/2018/2018-rugsejo-men/ataskaita_dujos_2018_09_19.pdf (accessed on 26 June 2019).

78. Alonso, S.; Herrera-Viedma, E.; Chiclana, F.; Herrera, F. A web based consensus support system for group decision making problems and incomplete preferences. Inf. Sci. 2010, 180, 4477-4495. [CrossRef]

79. Goepel, K.D. Implementation of an online software tool for the analytic hierarchy process —Challenges and practical experiences. Implement. Online Softw. Tool AHP Chall. Pract. Exp. 2017, 10, 1-20.

80. Goepel, K.D. Implementing the analytic hierarchy process as a standard method for multi-criteria decision making in corporate enterprises-A new AHP excel template with multiple inputs. In Proceedings of the International Symposium on the Analytic Hierarchy Process, Kuala Lumpur, Malaysia, 23-26 June 2013; Volume 1, pp. 1-10.

81. Jahanshahloo, G.R.; Lotfi, F.H.; Davoodi, A.R. Extension of TOPSIS for decision-making problems with interval data: Interval efficiency. Math. Comput. Model. 2009, 49, 1137-1142. [CrossRef]

82. Barton, B.; Redgwell, C.; Rønne, A.; Zillman, D.N. Energy Security: Managing Risk in a Dynamic Legal and Regulatory Environment; Oxford University Press on Demand: New York, NY, USA, 2004; p. 506.

83. Smaliukiene, R.; Monni, S. A step-by-step approach to social marketing in energy transition. Insights Reg. Dev. 2019, 1, 19-32. [CrossRef]

84. Mohitpour, M.; Golshan, H.; Murray, A. Natural Gas Transmission; ASME Press: New York, NY, USA, 2017; p. 200.

85. Kunitsyna, N.; Britchenko, I.; Kunitsyn, I. Reputational risks, value of losses and financial sustainability of commercial banks. Entrepreneurship Sustain. Issues 2018, 5, 943-955. [CrossRef] 
86. Juris, A. The Emergence of Markets in the Natural Gas Industry. The World Bank. 1998. Available online: http://documents.worldbank.org/curated/en/713751468739147642/127527322_20041117170610/add itional/multi-page.pdf (accessed on 26 June 2019).

87. Stern, J. Security of European Natural Gas Supplies; The Royal Institute of International Affairs: London, UK, 2002; Volume 7.

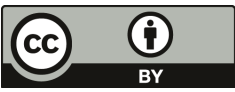

(C) 2019 by the authors. Licensee MDPI, Basel, Switzerland. This article is an open access article distributed under the terms and conditions of the Creative Commons Attribution (CC BY) license (http://creativecommons.org/licenses/by/4.0/). 
Article

\title{
Assessment of Green Investments' Impact on Sustainable Development: Linking Gross Domestic Product Per Capita, Greenhouse Gas Emissions and Renewable Energy
}

\author{
Serhiy Lyeonov ${ }^{1}$, Tetyana Pimonenko ${ }^{2}$, Yuriy Bilan ${ }^{3}$, Dalia Štreimikienè ${ }^{4, *}$ and \\ Grzegorz Mentel ${ }^{5}$ \\ 1 Economic Cybernetics Department, Sumy State University, 40007 Sumy, Ukraine; \\ s.lieonov@uabs.sumdu.edu.ua \\ 2 Marketing Department, Sumy State University, 40007 Sumy, Ukraine; \\ tetyana_pimonenko@econ.sumdu.edu.ua \\ 3 Faculty of Management, University of Social Science, 37-400 Lodz, Poland; yuriy_bilan@yahoo.co.uk \\ 4 Vilnius University, Kaunas Faculty, Mutines 8, LT-44280 Kaunas, Lithuania \\ 5 College of Management, Department of Economics and Finance, University of Information Technology and \\ Management in Rzeszow, 35-225 Rzeszow, Poland; gmentel@wsiz.rzeszow.pl \\ * Correspondence: dalia.streimikiene@lei.lt; Tel.: +370-6140-3424
}

Received: 27 August 2019; Accepted: 11 October 2019; Published: 15 October 2019

\begin{abstract}
The paper analyses the linkages between GDP per capita, greenhouse gas (GHG) emissions, and renewable energy (RE) in the total final energy consumption and green investments (PICE) which are measured as private investments, jobs, and gross value added related to circular economy sectors. The object of the analysis is the EU countries during the 2008-2016 period (crisis and post-crisis period). In the paper, data from the following databases was used: the Eurostat, the World Data Bank, and the European Environmental Agency. For addressing the linkages between the aforementioned indicators, the following methods were applied: panel unit root test, Pedroni panel cointegration tests, and the fully modified ordinary least squares (FMOLS) and dynamic ordinary least squares (DOLS) panel cointegration techniques. The findings show that FMOLS and DOLS demonstrate the same results as GHG, PICE, RE influence on GDP of the EU countries. The findings prove there is linking between gross domestic product per capita, greenhouse gas emissions, renewable energy in the total final energy consumption and green investments. The findings also show that green investment (PICE) could provoke the growth of GDP per capita by $6.4 \%$, the decline of GHG by $3.08 \%$, and the increase of renewable energy in the total final energy consumption by $5.6 \%$.
\end{abstract}

Keywords: sustainable development; renewable energy; greenhouse gas emissions; green investments

\section{Introduction}

The current tendency of greening the economic development contributes to analysing the most significant drivers that boost this process. All EU countries signed the agreement on achieving Sustainable Development Goals 2030 (SDGs 2030). According to this agreement, the EU countries, on a voluntary basis, try to reduce their negative impact on the environment and harmonise their economic, social, and environmental development. The results of many studies [1-5] indicate that one of the main drivers which provide the financial base for sustainable development is green investment. Several studies [6,7] have found that the biggest share of green investments was spent on spreading and implementing renewable energy which could reduce greenhouse gas emissions (GHG emissions) $[8,9]$. 
Noteworthy here, the experts have created the Sustainable development goal index to demonstrate countries' success on the way to achieving SDGs 2030. Thus, according to the official report [10], in 2018, the first five places were occupied by Sweden, Denmark, Finland, Germany. All these countries belong to the group of high-income countries in which 2016 Gross National Income (GNI) per capita was $\$ 12,235$ or higher. For these countries, allocation of additional capital for achieving SDGs is not a huge issue.

At the same time, such countries as Slovak Republic, Hungary, Portugal, Poland, Bulgaria, Serbia, Romania, Greece occupied the ranks from 25 to 48. Among these countries, three are high-income countries (Slovak Republic, Hungary and Greece) and upper-middle-income countries with 2016 GNI per capita being between \$3,956 and \$12,235 (Bulgaria, Serbia, Romania), only Moldova belongs to low middle-income countries in this group.

In this case, for upper and low middle-income countries allocation of additional financial resources is a big issue due to their unstable economic situation. As green investments can help in achieving important sustainable development goals: GDP per capita growth, increase of renewable energy utilisation and GHG emission reduction, the main input of this paper is to test this hypothesis and to assess the impact of green investments on GDP per capita, the share of renewables in the final energy consumption and GHG emissions in the EU member states and to develop policy recommendations stemming from the results of this empirical study.

As indicated above, increasing the share of renewable energy in the total energy consumption requires additional financial resources. In this case, it would be appropriate to analyse the statistical significance between GDP per capita, GHG emissions, renewable energy consumption and the volume of green investments. The authors of this paper have checked the following hypothesis:

H1: There is a linking between green investment, GDP per capita, GHG emissions and the share of renewable energy in the total energy consumption.

In the next section of this paper, data and methods used are presented. Note that our previous investigation has been focused on a more general analysis of green investment development. In this case, the object of our analysis is the EU countries during the 2008-2016 period while our purpose has been to explain that green investment is one of the ways to attract financial resources.

The reminder of the paper is structured in the following way: Section 2 provides a literature review on the subject and formulation of the hypothesis; Section 3 delivers data and methods applied in the study; Section 4 presents discussions of the results and Section 5 concludes.

\section{Literature Review}

The main dimensions of sustainable development then GDP per capita is growing selected for this study are as follows: use of renewable energy sources and GHG emission reduction. These are also the main EU energy policy targets including energy efficiency increase. In addition, increase of utilisation of renewable energy sources also provides for energy efficiency improvements [2].

According to the dataset, the EU as the whole tries to decrease the GHG emissions compare to the 1990 year (Figure 1).

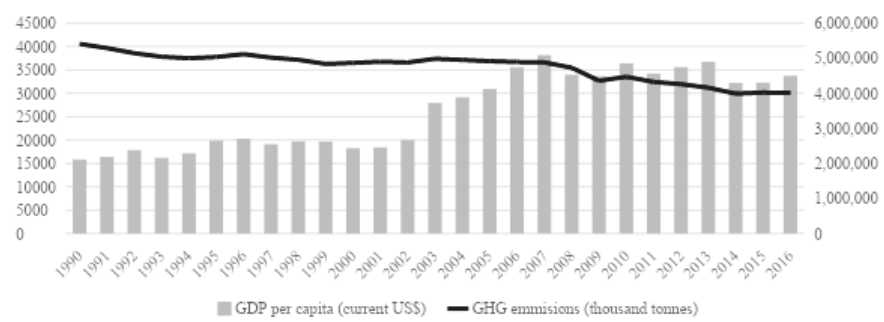

Figure 1. GDP per capita and greenhouse gas emissions (GHG) emissions for EU countries (1990-2016) [11,12]. 
In this case, the snowballing effect on decreasing GHG emissions could be achieved through increasing the share of renewable energy in total energy consumption (Figure 2).

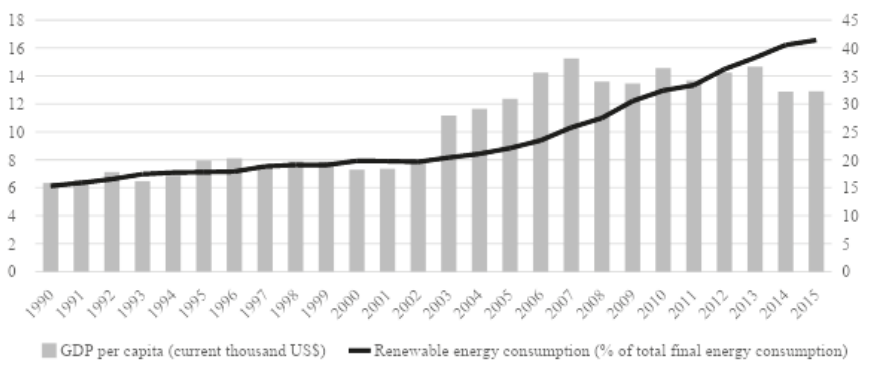

Figure 2. GDP per capita and renewable energy consumption for EU countries (1990-2015) [11,12].

The findings in Figures 1 and 2 showed that increasing the share of renewable energy in total energy consumption leads to decreasing GHG emissions.

The huge range of investigation deals with the analysis of preconditions to develop green investment market as a financial driver of sustainable development. However, according to the results of the previous investigations [13-23] the main factor which restricts the developing of green investment market is misunderstanding the meaning and goals of green investment among scientists, experts and investors. Thus, Martinez-Oviedo and authors in the papers [24-31] highlighted that green investment is a capital to low carbon and climate resilient initiatives, clean technologies, renewable energy, or natural capital that can be considered environmentally beneficial. The one group of scientists proved that the main goal of green investment is declining of $\mathrm{CO}_{2}$ emission [32-45]. The third group of scientists defined green investment as investment into renewable energy [46-63]. In this case, it is necessary to investigate and develop the universal approach to define and classify green investment which will be based on the classification of green assets.

It should be underlined, that a lot of the scientists investigate the relationship between economic development and efficiency of SDGs 2030 achieving through the analysis of linking between: Environmental Performance Index and countries GDP [31,64-67], Environmental Performance Index and Institutions Quality [68-72]; economic, social and ecological indicators of the countries development [73-84], socioeconomic development and economic growth [85], economic growth, environmental pollution and social development which measured by the level of morbidity [86-89].

The author Greco in the paper [89] analysed the sustainable economic development from the point of view of behavioural economics theory. Greco [89] highlighted that the economic growth related to the solving of social conflict and improving the quality of life and work conditions.

The scientist [90-95] proved the hypotheses on linking between ecological, social and economic indicators which influence on country's GDP. The scientists Zajaczkowska M. [95], Kisiała W. [96] and Malkina, M. [97] proved the relationship between social indicators, ecological indicators which include efficiency of renewable energy, macroeconomic stability in low-middle income countries [79-99]. Besides, the range of scientists [99] paid attention to analyse the linking between political parameters on economic growth (eliminating of the ecological factors).

Some group of authors in the paper [100-112] tried to prove the relationship between renewable energy, economic growth and volume of foreign direct investment in energy efficient projects and country's brand. In this case, the foreign direct investment analysed as the green investment by the authors. Noted, that using such types of green investment limited the complexity of impact analysis of green investment in the efficiency of sustainable economic development.

The findings allowed making conclusions that most investigation analysed the correlation between $\mathrm{CO}_{2}$ emissions, renewable energy and investment in renewable energy. Under this investigation, the authors analysed instead of $\mathrm{CO}_{2}$ emissions - GHG emission as it was indicated the goal of SDGs 
2030. Therefore, green investment was defined as the private investments, jobs, and gross value added related to circular economy sectors which are an integrated indicator which involves the social, ecological and economic impact of the investment.

\section{Data and Methods}

For checking $\mathrm{H} 1$ hypothesis and further analysis of the main drivers of sustainable development, the authors used the modified model of economic growth as follows:

$$
\mathrm{GDP}=\mathrm{F}(\mathrm{PICE}, \mathrm{GHG}, \mathrm{RE})
$$

where GDP - GDP per capita, PICE - private investments, jobs and gross value added related to circular economy sectors; GHG - GHG emission; RE - share of renewable energy in the total energy consumption.

Modified function (2) can be demonstrated as panel cointegration equation:

$$
\ln \mathrm{GDP}_{i \mathrm{t}}=\phi+\alpha \ln \mathrm{PICE}_{i \mathrm{t}}+\beta \ln \mathrm{GHG}_{i \mathrm{t}}+\gamma \ln \mathrm{RE}_{i \mathrm{t}}+\mu_{i \mathrm{t}}
$$

where $\alpha, \beta, \gamma$-regression's parameters which are evaluated and explain the elastic of output relate on PICE, GHG, RE; $\mu$ is the error term; $i=1, \ldots, N ; t=1, \ldots, T$.

For checking above-mentioned hypotheses, the authors used the databases as follows: World Data Bank, Eurostat, European Environmental Agency. For the analysis, the EU countries during the 2008-2016 period were chosen (Table 1).

Table 1. Indicators, meaning and sources for analysis

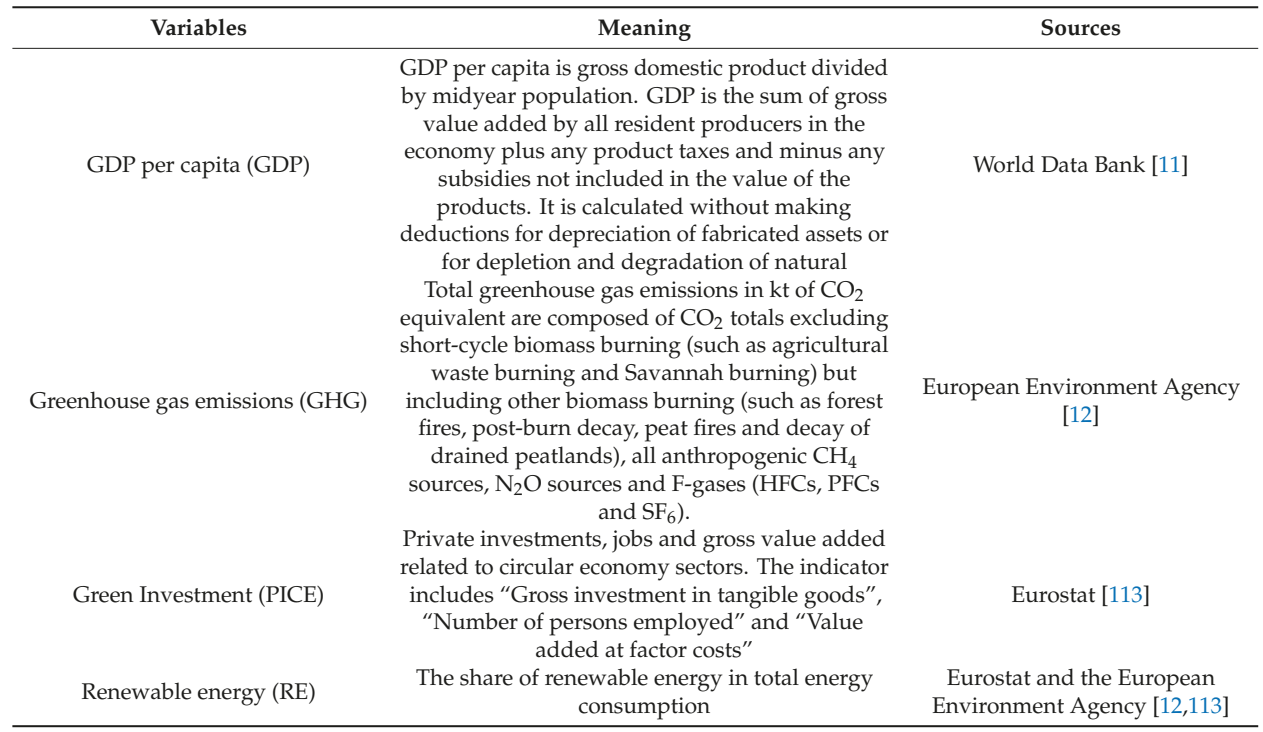

Sources: compiled by the authors.

Under the research, the following methods were used: panel unit root tests using the Im, Pesaran, and Shin's (IPS); Levin, Lin, and Chu test (LLC); and the Fisher-type tests (Augmented Dickey-Fuller test (ADF) Fisher and Phillips-Perron test (PP) Fisher). In the basis of the abovementioned tests is the checking of the hypothesis, which assumed the existing a unit root in the panel data on the time series and alternative absence in the unit root. 
With the purpose to check the long-term correlation, the authors used Pedroni test. If the cointegration exists, the long-run equilibrium relationship will estimate using the Fully Modified OLS (FMOLS) and Dynamic OLS (DOLS) panel cointegration techniques.

For analysis, the EU countries were chosen for period 2000-2016 years. Such countries were chosen as an example for the countries' potential candidate to EU membership to prove the efficiency of green investment and stimulate the attractiveness of green investment as a part of the direct foreign investment. Such investigation could be a base for the further analysis of options to minimize the gaps between EU policy and the countries' potential candidate to EU membership.

\section{Discussion of Results}

At the first stage, the panel unit root tests for parameters GDP, GHG, PICE, RE were done. The results of the panel unit root tests for GDP, GHG, PICE, RE were presented in Table 2.

Table 2. Panel unit root results for GDP, GHG, green investment (PICE), renewable energy (RE).

\begin{tabular}{|c|c|c|c|c|c|c|c|c|}
\hline \multirow{2}{*}{ Variables } & \multicolumn{2}{|c|}{ LLC } & \multicolumn{2}{|c|}{ IPS } & \multicolumn{2}{|c|}{ ADF } & \multicolumn{2}{|c|}{ PP } \\
\hline & Stat. & Prob. & Stat. & Prob. & Stat. & Prob. & Stat. & Prob. \\
\hline \multicolumn{9}{|c|}{ Level } \\
\hline GDP & -2.86 & 0.002 & 0.59 & 0.72 & 59.64 & 0.16 & 55.32 & 0.28 \\
\hline PICE & -4.13 & 0.00 & -0.16 & 0.44 & 64.16 & 0.12 & 58.66 & 0.24 \\
\hline GHG & -7.76 & 0.00 & -3.09 & 0.001 & 99.08 & 0.0001 & 154.09 & 0 \\
\hline $\mathrm{RE}$ & -6.04 & 0.00 & 0.58 & 0.28 & 74.01 & 0.02 & 88.57 & 0.0012 \\
\hline \multicolumn{9}{|c|}{ 1st differences } \\
\hline GDP & -24.05 & 0.00 & -9.54 & 0.00 & 184.36 & 0.00 & 260.56 & 0.00 \\
\hline PICE & -17.78 & 0.00 & -7.20 & 0.00 & 159.45 & 0.00 & 215.83 & 0.00 \\
\hline GHG & -20.57 & 0.00 & -9.52 & 0.00 & 191.90 & 0.00 & 261.07 & 0.00 \\
\hline $\mathrm{RE}$ & -11.76 & 0.00 & -5.04 & 0.00 & 132.10 & 0.00 & 177.93 & 0.00 \\
\hline
\end{tabular}

Sources: calculated by the authors.

The findings (Table 2) of using Levin Lin and Chu (LLC), Im Pesaran and Shin (IPS), ADF Fisher Chi-square and PP Fisher Chi-square tests confirmed that all variables were non-stationary at levels and after the first difference, all variable had become stationary. The obtained results allowed indicating the character of stationary of GDP, GHG, PICE, RE, for EU countries but also established the basis for panel cointegration analysis as the using of the regressions on non-stationary variables can give misleading parameter estimates in the economic relationship among variables. All findings are statistically significant at the level $-1 \%$ and $5 \%$. The findings allowed realising the test for panel cointegration between GDP, GHG, PICE, RE. The cointegration test was conducted using by the Pedroni panel cointegration tests (Table 3).

Table 3. Pedroni panel cointegration tests.

\begin{tabular}{|c|c|c|c|c|c|}
\hline \multirow{2}{*}{ Dimension } & \multirow{2}{*}{ Test Statistics } & \multirow{2}{*}{ Stat } & \multirow[b]{2}{*}{ Prob } & \multicolumn{2}{|c|}{ Weighted statistic } \\
\hline & & & & Stat & Prob \\
\hline \multirow{4}{*}{ Within-dimension } & panel v-statistic & -1.19 & 0.88 & -1.09 & 0.86 \\
\hline & panel rho-statistic & 2.54 & 0.99 & 2.70 & 0.99 \\
\hline & panel PP-statistic & -2.85 & $(0.002) * *$ & -2.83 & $(0.002)^{* *}$ \\
\hline & panel ADF-statistic & -2.85 & $(0.002) * *$ & -2.70 & $(0.0034) * *$ \\
\hline \multirow{3}{*}{ Between-dimension } & group rho-statistic & 5.02 & 1.00 & & \\
\hline & group PP-statistic & -3.20 & $(0.0007)^{* *}$ & & \\
\hline & group ADF-statistic & -2.32 & $(0.01)^{*}$ & & \\
\hline
\end{tabular}

Sources: calculated by the authors. 
Thus, the findings in Table 3 showed that six from eleven results of the test exclude null hypothesis (no cointegration of time series). Therefore, the obtained results affirmed the cointegration between GDP, GHG, PICE, RE for the EU countries existed on significance at the $1 \%$ and $5 \%$ levels. It allows making the conclusion, about the long-term relationship among GDP, GHG, PICE, RE which could be checked by using the FMOLS and DOLS panel cointegration techniques. For that purpose, four assumptions were checked:

- $\quad$ assumption 1: Influence of GHG, PICE, RE on GDP;

- $\quad$ assumption 2: Influence of GDP, PICE, RE on GHG;

- $\quad$ assumption 3: Influence of GDP, PICE, GHG on RE;

- $\quad$ assumptions 4: Influence of GDP, GHG, RE on PICE.

The obtained results of using FMOLS and DOLS panel cointegration techniques were presented in Table 4.

Table 4. The findings of the fully modified ordinary least squares (FMOLS) and dynamic ordinary least squares (DMOLS) panel cointegration techniques for four assumptions.

\begin{tabular}{|c|c|c|c|c|c|}
\hline \multicolumn{2}{|c|}{ Variables } & \multirow{2}{*}{$\begin{array}{l}\text { FMOLS } \\
\text { Coefficient }\end{array}$} & \multirow[b]{2}{*}{ Prob } & \multicolumn{2}{|l|}{ DMOLS } \\
\hline Dependent & Independent & & & Coefficient & Prob \\
\hline \multirow{3}{*}{ GDP } & PICE & 6.40 & $(0.00)$ * & 5.80 & $(0.00)$ * \\
\hline & GHG & 0.39 & $(0.00)$ * & 0.41 & $(0.00)$ * \\
\hline & RE & 38.18 & $(0.00)$ * & 37.24 & $(0.00)$ * \\
\hline \multirow{3}{*}{ GHG } & GDP & 9.35 & $(0.00)$ * & 9.33 & $(0.00)$ * \\
\hline & PICE & -3.08 & 0.27 & 4.61 & 0.33 \\
\hline & $\mathrm{RE}$ & -5139.85 & $(0.00)$ * & -5142.43 & $(0.00)$ * \\
\hline \multirow{3}{*}{ RE } & GDP & 0.002 & $(0.00)$ * & 0.0021 & $(0.00)$ * \\
\hline & PICE & 5.600 & $(0.00)$ * & 7.0 & $(0.0002)$ * \\
\hline & GHG & 0.01 & $(0.00)$ * & 0.0021 & $(0.003)$ * \\
\hline \multirow{3}{*}{ PICE } & GDP & 0.19 & $(0.0001)$ * & 0.21 & $(0.005) *$ \\
\hline & GHG & 0.004 & $(0.0003)$ * & 0.0053 & $(0.002) *$ \\
\hline & $\mathrm{RE}$ & 99.44 & $(0.01)^{* * *}$ & 100.31 & $(0.013)$ ** \\
\hline
\end{tabular}

Note: ${ }^{*}$ and ${ }^{* *}$ represents significance at the $1 \%$ and $5 \%$ levels.

Sources: calculated by the authors.

The findings showed that FMOLS and DOLS demonstrated the same results as GHG, PICE, RE influence on GDP for EU countries. The obtained results were statistical significance $-1 \%$ for all three parameters. Thus, the increasing by $1 \%$ of PICE leads to increasing of GDP by $6.4 \%$ (FMOLS) and $5.6 \%$ (DMOLS), the increasing by $1 \%$ of GHG lead to increasing of GDP by $0.39 \%$ (FMOLS) and $0.41 \%$ (DMOLS), the increasing by $1 \%$ of RE provoked the increasing of GDP by $38.18 \%$ (FMOLS) and $37.24 \%$ (DMOLS).

It should be noted, that increasing of RE by $1 \%$ lead to decreasing of GHG by $-5139.85 \%$. Therefore, increasing by $1 \%$ of PICE provoked the increasing of RE by $5.6 \%$ (FMOLS) and $7 \%$ (DOLS). At the same time, increasing of RE by $1 \%$ provoked the increasing of PICE by $99.44 \%$ (FMOLS).

The obtained results proved the hypothesis of linking between green investment, GDP, GHG emissions and share of renewable energy in the total energy consumption for EU countries. In this case, the findings proved that green investment could provoke the increase of the share of renewable energy in the total energy consumption and decreasing of GHG emissions. At the same time, the spreading of RE leads to declining of GHG.

Besides, all indicators green investment (PICE), GHG emission and share of renewable energy in the total energy consumption had a statistically significant impact on GDP. Thus, the increasing of green investment (PICE) could provoke the growth of GDP by $6.4 \%$, the declining of GHG by $3.08 \%$ and the increasing of renewable energy in the total energy consumption by $5.6 \%$ (FMOLS). 
The traditional investment market in the countries' potential candidate to EU membership should be "greening" (Figure 3).

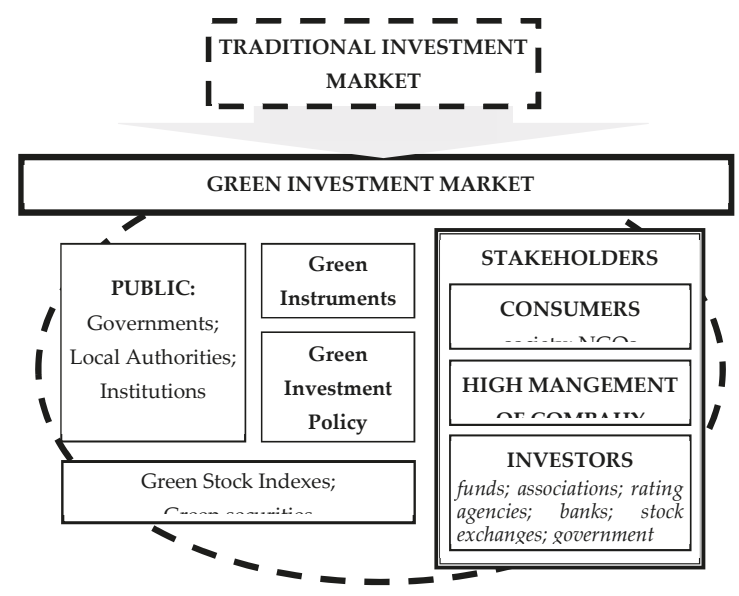

Figure 3. The framework concept of transformation from traditional to green investment market.

Source: developed by the authors on the basis [108-112,114,115].

The same analysis should be done for the countries' potential candidate to EU membership with the purpose to allocate the mechanism to minimize the negative imbalances in the EU on the way on achieving SDGs 2030. In this case, for further investigation, it is necessary to analyse the EU incentive mechanism to stimulate the attractiveness of green investment as a part of the direct foreign investment.

\section{Conclusions}

This empirical study has been operating data on the EU member states and the econometric modelling proves that green investments have a positive economic effect. The findings show that green investment could provoke the growth of GDP per capita by $6.4 \%$, reduction of GHG emissions by $3.08 \%$ and the increase of renewable energy in the total final energy consumption by $5.6 \%$. These findings proving there is cointegration between GDP and green investments are similar to the results presented in [32-45].

As the energy utility industries are the power generators of GDP and the causes of environmental damages in countries at the same time, their activities should be transformed according to the SDGs goals.

Such transformations so that to fit the SDGs require more of green investments for implementing more energy-efficient projects (oriented on renewable energy, clean technologies etc.). Together they would allow reducing GHG emissions.

The results of our analysis of the EU countries' experience in attracting green investments for renewable energy projects prove that openness and transparency of non-financial reporting are the main factors influencing investors' decisions.

Besides, regular publishing of non-financial reports leads to decreasing of greenwashing and strengthening of positive green brands. And this, in turn, would lead to increasing investing's attractiveness of companies for green investors.

As the EU experience shows, such reports should be published by companies on a regular basis and this norm should become obligatory on the government level. Moreover, potential candidates for the EU membership should analyse and implement incentive instruments so that to follow the principles of openness and transparency in their companies' non-financial reporting basing on the provided framework of transformation from traditional to green investment market. 
Author Contributions: S.L. and T.P., conceptualized this manuscript; T.P. prepared the database, methodology, software validation and wrote this manuscript, consolidated the literature reviewer; S.L., Y.B., D.Š., T.P. and G.M. reviewed the manuscript and assisted in writing and finalizing the manuscript.

Funding: This research was funded by the grant from the Ministry of Education and Science of Ukraine (№ g/r 0117U002251 and 0117U003932).

Conflicts of Interest: The authors declare no conflict of interest.

\section{References}

1. Raszkowski, A.; Bartniczak, B. Towards Sustainable Regional Development: Economy, Society, Environment, Good Governance Based on the Example of Polish Regions. Transform. Bus. Econ. 2018, 17, 225-245.

2. Dalevska, N.; Khobta, V.; Kwilinski, A.; Kravchenko, S. A model for estimating social and economic indicators of sustainable development. Entrep. Sustain. Issues 2019, 6, 1839-1860. [CrossRef]

3. Dabyltayeva, N.; Rakhymzhan, G. The green economy development path: Overview of economic policy priorities. J. Secur. Sustain. Issues 2019, 8, 643-651. [CrossRef]

4. Brożyna, J.; Mentel, G.; Szetela, B. Renewable energy and economic development in the European Union. Acta Polytech. Hung. 2017, 14, 11-34.

5. Matuszewska-Janica, A.; Żebrowska-Suchodolska, D.; Mentel, G. Evaluation of Short-Term Relationships between Selected Investment Funds and the Capital Market in Poland. Acta Polytech. Hung. 2019, 16, $25-41$.

6. Al-mulali, U.; Fereidouni, H.G.; Lee, J.Y.; Sab, C.N.B.C. Examining the bi-directional long run relationship between renewable energy consumption and GDP growth. Renew. Sustain. Energy Rev. 2013, 22, $209-222$. [CrossRef]

7. Ocal, O.; Aslan, A. Renewable energy consumption-economic growth nexus in Turkey. Renew. Sustain. Energy Rev. 2013, 28, 494-499. [CrossRef]

8. Sadorsky, P. Renewable energy consumption, $\mathrm{CO}_{2}$ emissions and oil prices in the $\mathrm{G} 7$ countries. Energy Econ. 2009, 31, 456-462. [CrossRef]

9. Chang, M.-C.; Shieh, H.-S. The Relations between Energy Efficiency and GDP in the Baltic Sea Region and Non-Baltic Sea Region. Transform. Bus. Econ. 2017, 16, 235-247.

10. Sachs, J.; Schmidt-Traub, G.; Kroll, C.; Lafortune, G.; Fuller, G. SDG Index and Dashboards Report 2018; Bertelsmann Stiftung and Sustainable Development Solutions Network (SDSN): New York, NY, USA, 2018.

11. European Environment Agency. Greenhouse Gas Emissions by Source Sector. 2019. Available online: https://ec.europa.eu/eurostat/data/database (accessed on 2 January 2019).

12. World Data Bank. World Development Indicators. 2019. Available online: https://databank.worldbank.org/ data/reports.aspx?source=2\&series=NY.GDP.PCAP.CD\&country=\# (accessed on 2 January 2019).

13. Chygryn, O.Y.; Krasniak, V.S. Theoretical and applied aspects of the development of environmental investment in Ukraine. Mark. Manag. Innov. 2015, 3, 226-234.

14. Štreimikienè, D.; Mikalauskienè, A.; Mikalauskas, I. Comparative Assessment of Sustainable Energy Development in the Czech Republic, Lithuania and Slovakia. J. Compet. 2016, 8, 31-41. [CrossRef]

15. Androniceanu, A.; Popescu, C.R. An inclusive model for an effective development of the renewable energies public sector. Adm. Public Manag. Rev. 2017, 81-96.

16. Anwar, S.; Nguyen, L.P. Foreign direct investment and economic growth in Vietnam. Asia Pac. Bus. Rev. 2010, 16, 183-202. [CrossRef]

17. Štreimikienè, D.; Strielkowski, W.; Bilan, Y.; Mikalauskas, I. Energy dependency and sustainable regional development in the Baltic states: A review. Geogr. Pannonica 2016, 20, 79-87. [CrossRef]

18. Djalilov, K.; Lyeonov, S.; Buriak, A. Comparative studies of risk, concentration and efficiency in transition economies. Risk Gov. Control Financ. Mark. Inst. 2015, 5, 178-187. [CrossRef]

19. Ibragimov, Z.; Lyeonov, S.; Pimonenko, T. Green investing for SDGS: EU experience for developing countries. Econ. Soc. Dev. Book Proc. 2019, 14, 867-876.

20. Chygryn, O.; Pimonenko, T.; Luylyov, O.; Goncharova, A. Green Bonds like the Incentive Instrument for Cleaner Production at the Government and Corporate Levels: Experience from EU to Ukraine. J. Environ. Manag. Tour. 2019, 9, 1443-1456. [CrossRef]

21. Kendiukhov, I.; Tvaronavičienè, M. Managing innovations in sustainable economic growth. Mark. Manag. Innov. 2017, 33-42. [CrossRef] 
22. Chygryn, $\mathrm{O}$. The mechanism of the resource-saving activity at joint stock companies: The theory and implementation features. Int. J. Ecol. Dev. 2016, 31, 42-59.

23. Li, J.; Sun, X.; Li, G. Relationships Among Green Brand, Brand Equity and Firm Performance: Empirical Evidence from China. Transform. Bus. Econ. 2018, 17, 221-236.

24. Martinez-Oviedo, R.; Medda, F. Real Natural Assets: The Real Green Investment Alternative. J. Altern. Investig. 2018, 21, 53-69.

25. Rajnoha, R.; Lesníková, P. Strategic Performance Management System and Corporate Sustainability Concept-Specific Parametres in Slovak Enterprises. J. Compet. 2016, 8, 107-154. [CrossRef]

26. Štreimikienė, D. Impact of environmental taxes on sustainable energy development in Baltic States, Czech Republic and Slovakia. Econ. Manag. 2015, 18, 4-23. [CrossRef]

27. Tvaronavičienè, A. The Possibilities to Use Public Procurement as One of the Instruments of Implementation of Sustainable Development Concept in Republic of Lithuania. Bus. Theory Pract. 2012, 13, 197-207. [CrossRef]

28. Vakulenko, I.; Myroshnychenko, I. Approaches to the organization of the energy efficient activity at the regional level in the context of limited budget resources during the transformation of energy market paradigm. Environ. Clim. Technol. 2015, 15, 59-76. [CrossRef]

29. Vasylyeva, T.A.; Pryymenko, S.A. Environmental economic assessment of energy resources in the context of ukraine's energy security. Actual Probl. Econ. 2014, 160, 252-260.

30. Yildiz, T. Environmental Reporting of Industrial and Supply Chain Business Processes within the Context of Sustainable Development. Bus. Theory Pract. 2011, 12, 5-14. [CrossRef]

31. Zaim, O. Measuring environmental performance of state manufacturing through changes in pollution intensities: A DEA framework. Ecol. Econ. 2004, 48, 37-47. [CrossRef]

32. Atari, S.; Bakkar, Y.; Olaniyi, E.O.; Prause, G. Real options analysis of abatement investments for sulphur emission control compliance. Entrep. Sustain. Issues 2019, 6, 1062-1087. [CrossRef]

33. Bilan, Y.; Streimikiene, D.; Vasylieva, T.; Lyulyov, O.; Pimonenko, T.; Pavlyk, A. Linking between renewable energy, $\mathrm{CO}_{2}$ emissions, and economic growth: Challenges for candidates and potential candidates for the EU membership. Sustainability 2019, 11, 1528. [CrossRef]

34. Cherchyk, L.; Shershun, M.; Khumarova, N.; Mykytyn, T.; Cherchyk, A. Assessment of forest enterprises' performance: Integrating economic security and ecological impact. Entrep. Sustain. Issues 2019, 6, 1784-1797. [CrossRef]

35. Dabija, D.C.; Bejan, B.M.; Dinu, V. How sustainability oriented is generation z in retail? A literature review. Transform. Bus. Econ. 2019, 18, 140-155.

36. Bilan, Y.; Gavurova, B.; Stanisław, G.; Tkacova, A. The Composite Coincident Indicator (CCI) for Business Cycles. Acta Polytech. Hung. 2017, 14, 71-90.

37. Eyraud, L.; Clements, B.; Wane, A. Green investment: Trends and determinants. Energy Policy 2013, 60, 852-865. [CrossRef]

38. Kubicová, J. Testing greenhouse gasses in Slovakia for environmental Kuznets curve and pollution haven hypothesis. J. Int. Stud. 2015, 7, 161-177. [CrossRef] [PubMed]

39. Lapinskienė, G.; Peleckis, K.; Nedelko, Z. Testing environmental Kuznets curve hypothesis: The role of enterprise's sustainability and other factors on GHG in European countries. J. Bus. Econ. Manag. 2017, 18, 54-67. [CrossRef]

40. Lyeonov, S.; Stoyanets, N.; Vysochyna, A.; Bilan, Y. The impact of environmental determinants of sustainable agriculture on country food security. Int. J. Environ. Technol. Manag. 2018, 21, 289-305. [CrossRef]

41. Martin, P.R.; Moser, D.V. Managers' green investment disclosures and investors' reaction. J. Account. Econ. 2016, 61, 239-254. [CrossRef]

42. Mentel, G.; Vasilyeva, T.; Pryymenko, S.; Samusevych, Y. Regional differentiation of electricity prices: Social-equitable approach. Int. J. Environ. Technol. Manag. 2018, 21, 354. [CrossRef]

43. Vysochyna, A.V.; Samusevych, I.V.; Tykhenko, V.S. The effect of tax tools in environmental management on region's financial potential. Actual Probl. Econ. 2015, 171, 263-269.

44. Yazdani-Chamzini, A.; Fouladgar, M.M.; Zavadskas, E.K.; Moini, S.H.H. Selecting the optimal renewable energy using multi criteria decision making. J. Bus. Econ. Manag. 2013, 4, 957-978. [CrossRef] 
45. Balitskiy, S.; Bilan, Y.; Strielkowski, W.; Štreimikienè, D. Energy efficiency and natural gas consumption in the context of economic development in the European Union. Renew. Sustain. Energy Rev. 2016, 55, 156-168. [CrossRef]

46. Baran, B. Support for renewable energy in Germany as an example of effective public policy. Oeconomia Copernic. 2015, 6, 143-158. [CrossRef]

47. Cebula, J.; Pimonenko, T. Comparison financing conditions of the development biogas sector in poland and ukraine. Int. J. Ecol. Dev. 2015, 30, 20-30.

48. Chygryn, O.; Petrushenko, Y.; Vysochyna, A.; Vorontsova, A. Assessment of Fiscal Decentralization Influence on Social and Economic Development. Montenegrin J. Econ. 2018, 14, 069-084. [CrossRef]

49. Eddelani, O.; El Idrissi, N.E.; Monni, S. Territorialized forms of production in Morocco: Provisional assessment for an own model in gestation. Insights Reg. Dev. 2019, 1, 6-18. [CrossRef]

50. Ginevicius, R.; Gedvilaite, D.; Stasiukynas, A. Impact of economic development on the ecology in the regions of Lithuania. Econ. Manag. 2018, 21, 21-37. [CrossRef]

51. Hagspiel, V.; Dalby, P.A.O.; Gillerhaugen, G.R.; Leth-Olsen, T.; Thijssen, J.J.J. Green investment under policy uncertainty and Bayesian learning. Energy 2018, 161, 1262-1281. [CrossRef]

52. Lyulyov, O.; Chortok, Y.; Pimonenko, T.; Borovik, O. Ecological and economic evaluation of transport system functioning according to the territory sustainable development. Int. J. Ecol. Dev. 2015, 30, 1-10.

53. Pimonenko, T.; Chayen, S.V.; Cebula, J.; Chygryn, O. Biogas as an alternative energy source in Ukraine and Israel: Current issues and benefits. Int. J. Environ. Technol. Manag. 2018, 21, 421. [CrossRef]

54. Yevdokimov, Y.; Chygryn, O.; Pimonenko, T.; Lyulyov, O. Biogas as an alternative energy resource for ukrainian companies: EU experience. Innov. Mark. 2018, 14, 7-15. [CrossRef]

55. Mielke, J.; Steudle, G.A. Green Investment and Coordination Failure: An Investors' Perspective. Ecol. Econ. 2018, 150, 88-95. [CrossRef]

56. Pimonenko, T.; Prokopenko, O.; Dado, J. Net zero house: EU experience in Ukrainian conditions. Int. J. Ecol. Econ. Stat. 2017, 38, 46-57.

57. Prokopenko, O.; Cebula, J.; Chayen, S.; Pimonenko, T. Wind energy in Israel, Poland and Ukraine: Features and opportunities. Int. J. Ecol. Dev. 2017, 32, 98-107.

58. Simionescu, M.; Albu, L.L.; Raileanu Szeles, M.; Bilan, Y. The impact of biofuels utilisation in transport on the sustainable development in the European Union. Technol. Econ. Dev. Econ. 2017, 23, 667-686. [CrossRef]

59. Šincāns, E.; Ignatjeva, S.; Tvaronavičienè, M. Issues of Latvian Energy Supply Security: Evaluation of Criminal Offences in Latvia's Electricity Market. Econ. Sociol. 2016, 9, 322-335. [CrossRef]

60. Smaliukienè, R.; Monni, S. A step-by-step approach to social marketing in energy transition. Insights Reg. Dev. 2019, 1, 19-32. [CrossRef]

61. Suska-Szczerbicka, M. Wind energy financing tools. Econ. Sociol. 2010, 3, 141-160. [CrossRef]

62. Vasylyeva, T.A.; Leonov, S.V.; Lunyakov, O. Countercyclical capital buffer as a macroprudential tool for regulation of the financial sector. Actual Probl. Econ. 2014, 8, 278-283.

63. Zakharkina, L.; Myroshnychenko, I.; Smolennikov, D.; Pokhylko, S. Efficiency of Innovation Activity Funding as the Driver of the State's National Economic Security. Montenegrin J. Econ. 2018, 14, 159-173. [CrossRef]

64. Ptak, M. Directions of changes in the functioning of economic instruments for environmental policy in Poland. Equilib. Q. J. Econ. Econ. Policy 2015, 5, 129-140. [CrossRef]

65. Sjaifuddin, S. Environmental management prospects of industrial area: A case study on MCIE, Indonesia. Bus. Theory Pract. 2018, 19, 208-216. [CrossRef]

66. Štreimikienè, D.; Mikalauskienè, A. Green growth and use of EU structural funds in Baltic states, Czech Republic and Slovakia. Econ. Manag. 2016, 19, 55-72. [CrossRef]

67. Szyja, P. The role of the state in creating green economy. Oeconomia Copernic. 2016, 7, 207-222. [CrossRef]

68. Dkhili, H. Environmental performance and institutions quality: Evidence from developed and developing countries. Mark. Manag. Innov. 2018, 3, 333-344. [CrossRef]

69. Stjepanović, S.; Tomić, D.; Škare, M. A new approach to measuring green GDP: a cross-country analysis. Entrep. Sustain. Issues 2017, 4, 574-590. [CrossRef]

70. Vasilyeva, T.; Lyeonov, S.; Adamičková, I.; Bagmet, K. Institutional quality of social sector: The essence and measurements. Econ. Sociol. 2018, 11, 248-262. [CrossRef]

71. Vasylieva, T.A.; Kasyanenko, V.O. Integral assessment of innovation potential of Ukraine's national economy: A scientific methodical approach and practical calculations. Actual Probl. Econ. 2013, 144, 50-59. 
72. Xiong, Z.; Ye, J.; Wang, P. Does the institutional environment affect the failed technological innovation in firms? Evidence from listed companies in china's pharmaceutical manufacturing industry. Transform. Bus. Econ. 2019, 18, 60-80.

73. Abaas, M.S.M.; Chygryn, O.; Kubatko, O.; Pimonenko, T. Social and economic drivers of national economic development: The case of OPEC countries. Probl. Perspect. Manag. 2018, 16, 155-168. [CrossRef]

74. Abrhám, J.; Britchenko, I.; Jankovic, M.; Garškaitè-Milvydienė, K. Energy Security Issues in Contemporary Europe. J. Secur. Sustain. Issues 2018, 7, 387-398. [CrossRef]

75. Bajdor, P. Comparison between sustainable development concept and Green Logistics: The literature review. Pol. J. Manag. Stud. 2012, 5, 225-233.

76. Ivanova, E.; Kordos, M. Competitiveness and innovation performance of regions in Slovak Republic. Mark. Manag. Innov. 2017, 145-158. [CrossRef]

77. Lapinskienė, G.; Peleckis, K.; Slavinskaitè, N. Energy consumption, economic growth and greenhouse gas emissions in the European Union countries. J. Bus. Econ. Manag. 2017, 18, 1082-1097. [CrossRef]

78. Lavrinenko, O.; Ignatjeva, S.; Ohotina, A.; Rybalkin, O.; Lazdans, D. The Role of Green Economy in Sustainable Development (Case Study: The EU States). Entrep. Sustain. Issues 2019, 6, 1113-1126. [CrossRef]

79. Lyeonov, S.V.; Vasylieva, T.A.; Lyulyov, O.V. Macroeconomic stability evaluation in countries of lower-middle income economies. Nauk. Visnyk Natsionalnoho Hirnychoho Universytetu 2018, 138-146. [CrossRef]

80. Maftei, D. A new approach for energy security: The efficient management of funds for investment in infrastructure for green energy. Pol. J. Manag. Stud. 2012, 5, 242-249.

81. Masood, O.; Tvaronavičienè, M.; Javaria, K. Impact of oil prices on stock return: Evidence from G7 countries. Insights Reg. Dev. 2019, 1, 129-137. [CrossRef]

82. Okuneviciute Neverauskiene, L.; Rakauskiene, O. Identification of employment increasing possibilities in the context of the EU socioeconomic environment evaluation: The case of Lithuania. Econ. Sociol. 2018, 11, 51-68. [CrossRef]

83. Vasilyeva, T.A.; Leonov, S.V.; Lunyakov, O.V. Analysis of internal and external imbalances in the financial sector of Ukraine's economy. Actual Probl. Econ. 2013, 150, 176-184.

84. Gupta, R. Socioeconomic challenges and its inhabitable global illuminations. Bus. Ethics Leadersh. 2017, 2, 81-85. [CrossRef]

85. Kasperowicz, R.; Pinczyński, M.; Khabdullin, A. Modeling the power of renewable energy sources in the context of classical electricity system transformation. J. Int. Stud. 2017, 10, 264-272. [CrossRef]

86. Lu, J.; Ren, L.; Lin, W.; He, Y.; Streimikis, J. Policies to Promote Corporate Social Responsibility (CSR) and Assessment of CSR Impacts. Econ. Manag. 2019, 22, 82-98. [CrossRef]

87. Kharlamova, G.; Vertelieva, O. The international competitiveness of countries: Economic-mathematical approach. Econ. Sociol. 2013, 6, 39-52. [CrossRef]

88. Kharlamova, G.; Chernyak, O.; Nate, S. Renewable energy and security for Ukraine: Challenge or smart way? J. Int. Stud. 2018, 9, 88-115. [CrossRef]

89. Greco, F. Resilience: Transform adverse events into an opportunity for growth and economic sustainability through the adjustment of emotions. Bus. Ethics Leadersh. 2018, 2, 44-52. [CrossRef]

90. Leonov, S.V.; Vasylieva, T.A.; Tsyganyuk, D.L. Formalization of functional limitations in functioning of co-investment funds basing on comparative analysis of financial markets within FM CEEC. Actual Probl. Econ. 2012, 134, 75-85.

91. Leonov, S. Potential of Institutional Investors and Stock Market Development as an Alternative to Households' Savings Allocations in Banks. Економічний часопис-XXI 2014, 11-12, 65-68.

92. Panayotou, T. Empirical Tests and Policy Analysis of Environmental Degradation at Different Stages of Economic Development; No. 992927783402676; International Labour Organization: Geneva, Switzerland, 1993.

93. Arribas, I.; Espinós-Vañó, M.D.; García, F.; Tamosiuniene, R. Negative screening and sustainable portfolio diversification. Entrep. Sustain. Issues 2019, 6, 1566-1586. [CrossRef]

94. Vasile, E.; Balan, M.; Balan, G.-S.; Grabara, I. Measures to reduce transportation greenhouse gas emissions in Romania. Pol. J. Manag. Stud. 2012, 6, 215-223.

95. Zajączkowska, M. Prospects for the development of prosumer energy in Poland. Oeconomia Copernic. 2016, 7, 439-449. [CrossRef]

96. Kisiała, W.; Suszyńska, K. Economic growth and disparities: An empirical analysis for the Central and Eastern European countries. Equilib. Q. J. Econ. Econ. Policy 2017, 12, 613-631. [CrossRef] 
97. Malkina, M. Contribution of various income sources to interregional inequality of the per capita income in the Russian Federation. Equilib. Q. J. Econ. Econ. Policy 2017, 12, 399-416. [CrossRef]

98. Singh, S.N. Regional Disparity and Sustainable Development in NorthEastern States of India: A Policy Perspective. Socioecon. Chall. 2018, 2, 41-48. [CrossRef]

99. Yevdokimov, Y.; Melnyk, L.; Lyulyov, O.; Panchenko, O.; Kubatko, V. Economic freedom and democracy: Determinant factors in increasing macroeconomic stability. Probl. Perspect. Manag. 2018, 16, 279-290. [CrossRef]

100. Alfaro, L.; Chanda, A.; Kalemli-Ozcan, S.; Sayek, S. FDI and economic growth: The role of local financial markets. J. Int. Econ. 2004, 64, 89-112. [CrossRef]

101. Bhandari, M.P. Impact of Tourism of Off Road Driving on Vegetation Biomass, a Case Study of Masai Mara National Reserve, Narok, Kenya. Socioecon. Chall. 2018, 3, 6-25. [CrossRef]

102. Bhowmik, D. Financial Crises and Nexus Between Economic Growth and Foreign Direct Investment. Financ. Mark. Inst. Risks 2018, 2, 58-74. [CrossRef]

103. Fogarassy, C.; Neubauer, É.; Mansur, H.; Tangl, A.; Oláh, J.; Popp, J. The main transition management issues and the effects of environmental accounting on financial performance-with focus on cement industry. Adm. Manag. Public 2018, 31, 52-66. [CrossRef]

104. Lin, B.; Benjamin, I.N. Causal relationships between energy consumption, foreign direct investment and economic growth for MINT: Evidence from panel dynamic ordinary least square models. J. Clean. Prod. 2018, 197, 708-720. [CrossRef]

105. Lyulyov, O.; Chygryn, O.; Pimonenko, T. National brand as a marketing determinant of macroeconomic stability. Mark. Manag. Innov. 2018, 142-152. [CrossRef]

106. Mačaitytė, I.; Virbašiūtė, G. Volkswagen Emission Scandal and Corporate Social Responsibility-A Case Study. Bus. Ethics Leadersh. 2018, 2, 6-13. [CrossRef]

107. Mashokhida, A.; Khabibovich, A.A.; Pálka, P.; Shakhlo, R. The competitiveness and sustainable economic development of tajikistan regions. J. Compet. 2018, 10, 73-88. [CrossRef]

108. Bilan, Y.; Vasylieva, T.; Lyeonov, S.; Tiutiunyk, I. Shadow economy and its impact on demand at the investment market of the country. Entrep. Bus. Econ. Rev. 2019, 7, 27-43. [CrossRef]

109. Sokolenko, L.F.; Tiutiunyk, I.V.; Leus, D.V. Ecological and economic security assessment in the system of regional environmental management: A case study of ukraine. Int. J. Ecol. Dev. 2017, 32, 27-35.

110. Vasylieva, T.; Lyulyov, O.; Bilan, Y.; Streimikiene, D. Sustainable economic development and greenhouse gas emissions: The dynamic impact of renewable energy consumption, GDP, and corruption. Energies 2019, 12, 3289. [CrossRef]

111. Bilan, Y.; Vasilyeva, T.; Lyulyov, O.; Pimonenko, T. EU vector of Ukraine development: Linking between macroeconomic stability and social progress. Int. J. Bus. Soc. 2019, 20, 433-450.

112. Ch, A.R.; Semenoh, A.Y. Non-bank financial institutions activity in the context of economic growth: Cross-country comparisons. Financ. Mark. Inst. Risks 2017, 1, 39-49.

113. Private Investments, Jobs and Gross Value Added Related to Circular Economy Sectors. Eurostat. 2019. Available online: https://ec.europa.eu/eurostat/databrowser/view/cei_cie010/default/table?lang=en (accessed on 2 January 2019).

114. Vasilyeva, T.; Sysoyeva, L.; Vysochyna, A. Formalization of factors that are affecting stability of ukraine banking system. Risk Gov. Control Financ. Mark. Inst. 2016, 6, 7-11. [CrossRef]

115. Bilan, Y.; Lyeonov, S.; Lyulyov, O.; Pimonenko, T. Brand management and macroeconomic stability of the country. [Zarządzanie marką i stabilność makroekonomiczna kraju]. Pol. J. Manag. Stud. 2019, 19, 61-74. [CrossRef]

(C) 2019 by the authors. Licensee MDPI, Basel, Switzerland. This article is an open access article distributed under the terms and conditions of the Creative Commons Attribution (CC BY) license (http://creativecommons.org/licenses/by/4.0/). 
Article

\title{
Pro-Environmental Energy Behavior in the Military: Assessing Behavior Change Factors at a Selected Military Unit
}

\author{
Rasa Smaliukiene ${ }^{1,2, *}$, Gintaras Labutis ${ }^{1}$ and Ausrius Juozapavicius ${ }^{1}$ \\ 1 General Jonas Zemaitis Military Academy of Lithuania, Silo 5a, 10322 Vilnius, Lithuania; \\ gintaras.labutis@lka.lt (G.L.); ausrius.juozapavicius@lka.lt (A.J.) \\ 2 Department of Creative Communication, Vilnius Gediminas Technical University, Sauletekio 11a, \\ 10223 Vilnius, Lithuania \\ * Correspondence: rasa.smaliukiene@lka.lt
}

Received: 2 December 2019; Accepted: 26 December 2019; Published: 2 January 2020

\begin{abstract}
The purpose of this study is to explore how pro-environmental energy behavior is manifested at a military unit and what behavioral change factors can enhance such behavior. The military unit represents an organization dominated by an exceptionally strong sense of community and belonging where individual pro-environmental energy behavior goes in line with a collective one. The application of Capability-Opportunity-Motivation-Behavior (COM-B) approach led to a better understanding of energy-saving behavior in the military as an organization where personnel are trained to increase their awareness of their peers' behavior. Methods: The results were obtained using data collected from two independent samples of both professional soldiers and conscripts at a military unit of Lithuanian defense forces located in a fixed installation in the time frame of 2018-2019. The total sample of respondents (professional soldiers and conscripts) was $\mathrm{N}=454$. A series of statistical tests were performed at the 0.05 level of confidence. Results: An extended COM-B model for the analysis of pro-environmental energy behavior in the military was proposed and applied. The results show that the three behavioral change factors—capability, opportunity, and motivation—are first of all positively linked with the collective energy behavior at the military unit and only then with the individual soldier's pro-environmental energy behavior. This is a new insight into the COM-B model as collective and individual behavior are identified as separate indicators and then combined into a single measurable construct. In addition, the results indicate that in the military unit, communality plays an important role in sustaining pro-environmental energy behavior, even if an individual behavior indicates low-involvement.
\end{abstract}

Keywords: energy security; pro-environmental behavior; energy usage; military energy behavior; behavioral change; COM-B; collective behavior; conscripts; professional soldiers

\section{Introduction}

Attention towards energy and energy security over the last decade increased as the efficient military energy usage is considered to be one of the key enablers of military operational capabilities. This trend is reflected in European Union (EU) and NATO strategic priorities and initiatives that underline the importance of ensuring energy security for military operations as well as reducing the environmental impact of military operations [1-3]. In addition, a portion of research, technology, and innovation (RTI) projects in military and defense are focused on energy and particularly on renewable energy solutions. In general, three key factors that affect energy usage can be listed: energy generation technologies, energy management, and energy data collection and analysis systems together with energy behavior at military units $[4,5]$. Resonating with an overall trend in energy transition 
towards pro-environment energy usage [6-8], military RTI initiatives stress on technological solutions. Meanwhile, the energy behavior remains an inadequately explored factor in reducing the energy usage and thus increasing military energy security [9] and energy efficiency [10]. Even though energy behavior in the military is gaining more attention, overall attempts in changing energy behavior of military personnel remains a managerial challenge.

The Capability-Opportunity-Motivation-Behavior (COM-B) model proposed by Michie et al. [11] and tested in numerous research projects is applied in this paper to investigate the energy-saving behavior in the military. The application of COM-B model to energy behavior leads to a better understanding of pro-environmental behavior in the military and facilitates a detailed analysis of the factors affecting this behavior. The model works in a context where three factors of the behavior (capability, opportunity, and motivation) are surrounded by managerial interventions, organizational policies, and limitations.

In the military context energy behavior is rooted into the trilemma of: (i) how to assure energy security for the military operations, (ii) how to use energy efficiently, and (iii) how to reduce the environmental impact of the operations [1]. In this context, energy behavior plays a critical role after the energy policies and standard operating procedures are introduced and related technologies are deployed. All three considerations are gradually translated into the requirements for the United Nations (UN) peacekeeping operations as well as EU and NATO military environment promoting not only technological development but also energy behavioral changes. Specifically, the UN peacekeeping forces had implemented environmental policies in all peacekeeping missions since 2009 [12]. This includes the requirements for environmental management systems that include energy, water, and waste management. As a new step in promoting pro-environmental energy usage in the military, the UN introduced its Environment Strategy of the UN Department of Field Support (DFS) which came into effect in January 2017. Its energy related objective "to reduce overall demand for energy through efficiencies" is planned to be realized by 2023 [2] (p. 2). This includes not only the requirements for energy efficient infrastructure but also the behavioral incentives where "awareness-raising and behavioral change" [2] (p. 2) play an important role. In general, the UN initiatives complement NATO's approach on energy security, energy resilience, and the protection of critical energy infrastructure. The improvement of energy efficiency becomes one of the key priorities $[10,13]$, therefore NATO's approach is also focused on the military by "reducing the energy consumption of military vehicles and camps, as well as minimizing the environmental footprint of military activities" [14]. At the Brussels Summit in 2018, those priorities were emphasized to the Member States underlining the importance of "more education and training opportunities" [3]. This highly resonates with energy priorities in security and other sectors [15]. Energy and energy security as the strategic priority was elaborated through the activities of NATO Energy Security Center of Excellence that was established in Lithuania in 2012 in order to assist Strategic Commands, other NATO bodies, nations, partners, and other civil and military entities by supporting NATO's capability development process, mission effectiveness, and interoperability by providing comprehensive and timely subject matter expertise on all aspects of energy security.

Given the situation where the energy policies and standard operating procedures are already introduced, and energy related technologies are deployed the COM-B model explaining the behavior change factors becomes an effective tool for the further research of military energy behavior. According to the model's designers Michie et al. [11], three factors heavily influence the behavior: capability $(\mathrm{C})$, opportunity $(\mathrm{O})$, and motivation $(\mathrm{M})$ (Figure 1). The model explores individual's behavior in the organizational context and provides the basis for managerial interventions [16], as well as includes main steps for behavioral change [17]. According to this model, all three conditions must be met in order to make an influence on individual's energy behavior: the individual's physical and social capability, individual's social and physical ability to explore new opportunities, and self-motivation as the crucial part of the behavior change [18]. This model was theoretically grounded and applied in a wide variety of contexts: nutrition [19], smoking [20], physical activity [21], as well as for energy 
use by households [22] and other end-users [23]. The COM-B model was applied to improve energy behavior in the military too [14,24]. However, those behavioral interventions in military and defense were purely practical and lacked intrinsic validity. This suggests that the COM-B model should first of all be tested as a solution/construct in the military context.

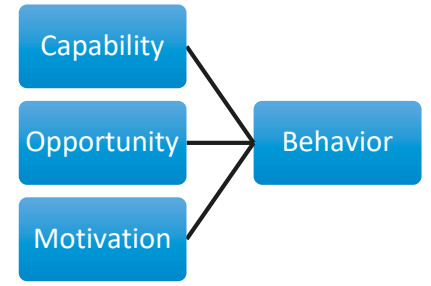

Figure 1. The original construct of COM-B model for behavioral change [11,16,21].

Assuming that a military context differs from a civilian context, the COM-B model needs to be validated and factors influencing the pro-environmental energy behavior in the military need to be identified. Studies showed that military members are indoctrinated already at the beginning of their military career [25]. Consequently, military culture penetrates attitudes and behavior, whereas individuals report strong identification with the military [26-28]. The military's impact on an individual increases along the duration of the military service [29]. Based on this evidence it could be assumed that the awareness of energy criticality in the military is increasing over the years of service, as shown by research in military energy efficiency [10]. Capability, opportunity and motivation affecting pro-environmental energy behavior are positively strengthened with the understanding that energy in military is considered to be a critical combat's "tooth" [1]. These considerations are taken into account when planning and conducting military operations for professional soldiers as well as for military conscripts. It is also assumed that the conscripts' perception of the importance of energy in the military differs from the professional soldiers. The conscripts are serving for a short term and they can be not yet fully indoctrinated [30]. Their capabilities, opportunities, and motivation to behave in a pro-environmental way could be linked to their civil life experiences of a green lifestyle [31] and not to the military service.

Efficient usage of military equipment and infrastructure is perceived as a potential for the freedom of action and an opportunity for enhanced capabilities of the military operations [1]. Consequently, important parts of the military's RTI are directed at addressing those issues. For example, new technologies that are used in expeditionary environment as well as in fixed military installations are focused on improving energy supply and reducing the usage [32,33], but the awareness of energy behavior remains limited. Despite the emphasis on technical solutions related to energy, the call for behavioral change at a unit level remains a priority $[10,34]$. Considering that at military bases soldiers are semi-isolated from their existing ties as well as their life outside the military, their bond with a military unit rises [35], and therefore, pro-environmental energy behavior must be analyzed not only from an individual's behavioral perspective, but also from the individual's social identification with the military unit. During the demanding military training, professional soldiers as well as conscripts are trained in order to increase their awareness of their own behavior in the context of the unit and their peers [35]. Therefore, COM-B model must focus not only on the individual's behavior, but also include the collective military behavior of the military unit.

The unique feature of our research is that we disaggregate two groups of energy behavior: individual energy behavior ("my" behavior) and unit energy behavior ("our" behavior). While the former follows the COM-B traditional paradigm used and validated in a series of studies (e.g., $[11,16,21,36])$, the latter relies exclusively on military research that puts a stress on soldier's bond with a military unit $[28,37]$. 
The purpose of this study is to explore how a politically and institutionally favorable environment that forces military transition towards the pro-environmental energy behavior is reflected at a military unit level. The rest of the paper proceeds as follows. First, we outline our research instrument and measurement model by extending the construct of COM-B model for behavioral change in the military. Next, we perform data analysis using a series of statistical tests. By applying the COM-B model we investigate energy behavioral factors and postulate that the three behavioral change factors-capability, opportunity, and motivation-are positively linked not only with individual soldier's behavior, but also with a collective energy behavior of the unit. Finally, discussion and conclusions are presented in the last section.

\section{Materials and Methods}

To measure the relationships between energy behavior in the military and affecting factors we collected data by making an annual survey for two consecutive years. The research was performed using traditional paper questionnaires at a selected Lithuanian military unit (fixed installation). The first survey was executed in October 2018 followed by the second survey in October 2019. During the first stage of data collection, 235 soldiers, non-commissioned officers, and officers were surveyed, while during the second stage the number of respondents was 219 soldiers, NCOs, and officers. Most respondents were conscripts (70 percent), followed by professional soldiers, NCOs, and officers (30 percent). Hence, the total sample was $N=454$. Detailed demographic information of the respondents is presented in Table 1. In some categories, the sum of all answers is less than $100 \%$ due to some missing responses. They were eliminated from further analysis.

Table 1. Demographic information of the respondents.

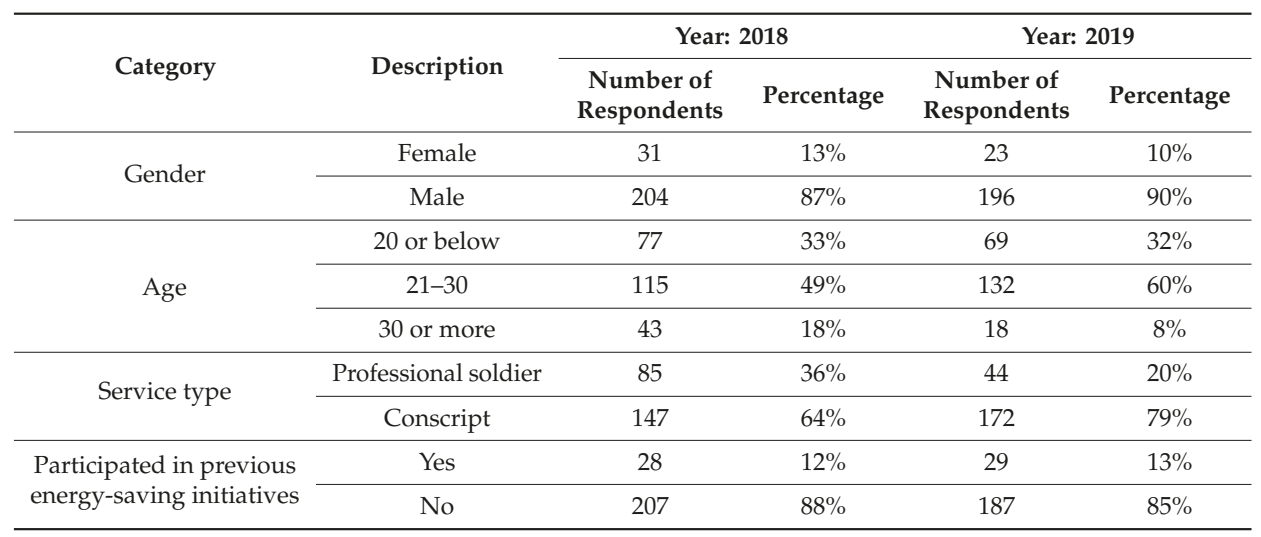

The questionnaire consisted of Likert one-to-five scale questions where value 1 corresponded to "strongly agree" and value 5 to "strongly disagree". In total there were 18 randomly listed statements related to COM-B measuring three latent variables: Motivation to save energy, Capabilities of the respondents, and available opportunities to exhibit the energy-saving behavior. Five statements were related to the capability category, seven statements to the opportunity category, and four to motivation. Two questions were attributed to the behavior category; they are analyzed later in the text. The ordinal scale of Likert questions limited statistical comparisons, and therefore several questions were included to measure the same variable, e.g., if three questions are used then the sum of the answers to these questions goes from 3 to 15, therefore it can be treated as an interval variable. We used Cronbach's alpha (CA) coefficient to measure the internal consistency of the composing questions. During the process, one motivation-related question and two capability-related questions were eliminated from 
further analysis due to their detrimental effect on the CA coefficient of the corresponding variables. In other words, they were independently measuring something else than intended.

The three latent variables, their questions, and reliability (the CA coefficients) are presented in Table 2. Observed variables were also validated individually: none of them have more than $5 \%$ of the missing values. Average values of all questionnaire answers are presented in Figure 2.

Table 2. Variables and their corresponding questions of the COM-B questionnaire.

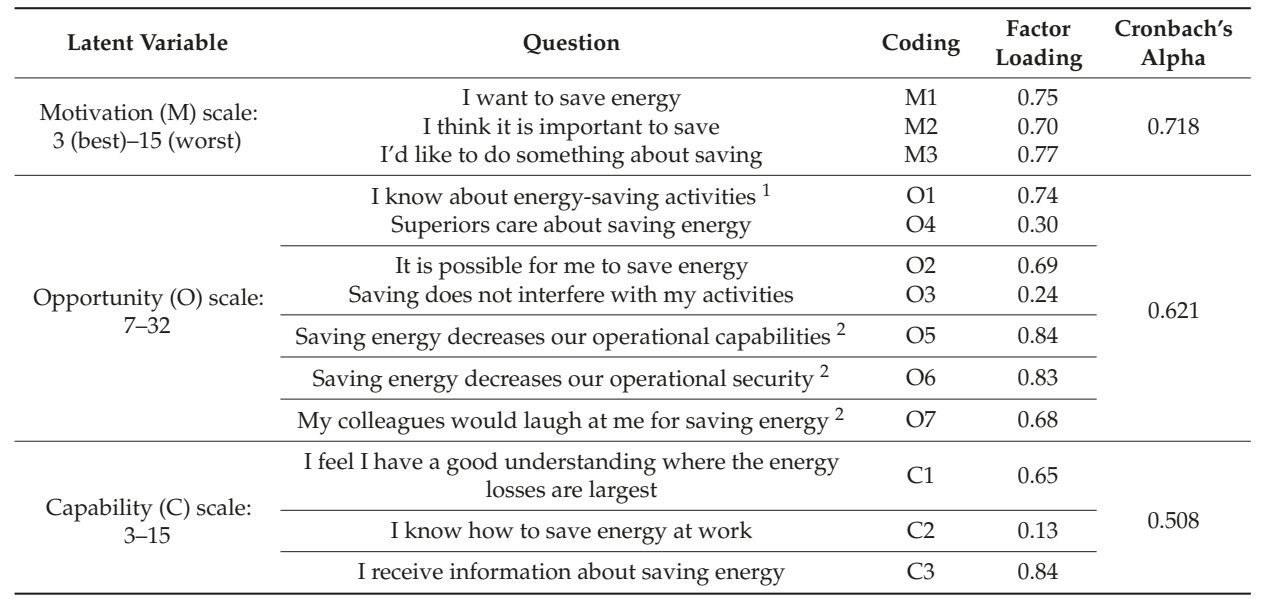

${ }^{1}$ The question had only two values-Yes and No. ${ }^{2}$ The answers had to be inverted before performing the analysis.

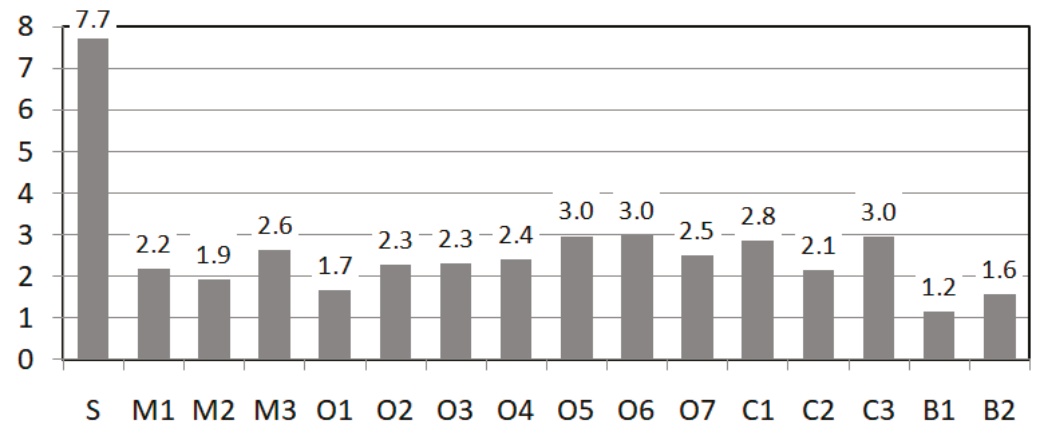

Figure 2. Average values of all answers. "S" denotes overall satisfaction (max 10), "B1"— "my" behavior, "B2"-_"our" behavior, other variables are defined in Table 2, and they range from 1 (best) to 5 (worst).

Additionally, we performed the principal component analysis on all answers of the questionnaire using SPSS software in order to assess its internal consistency. Sum of eigenvalues of the main five components covered almost $60 \%$ of the variance. The first component corresponded exactly with the motivation questions, explaining their high CA coefficient and the reliability of measurement. The questions have high loading factors above 0.7 (see Table 2) and their contribution to other latent variables is negligible. The second component grouped questions C1 and C3, with the C2 question also having a large load (0.71) in the third component and therefore significantly decreasing the reliability of capability measurements-it is the lowest among the latent variables. The remaining seven questions were grouped into three components separated in Table 2 by horizontal lines, where O5, O6 and O7 constituted the strongest component of the three, $\mathrm{O} 1$ went together with $\mathrm{O} 4$, and the last component consisted of $\mathrm{O} 2$ and $\mathrm{O} 3$. Together the seven questions were assigned to the opportunity variable as 
initially intended. Overall, the analysis validated the independence of the three latent variables and the reliability of their measurement.

According to the COM-B model [38] the behavior is determined by the three constituting factors: the previously defined latent variables Capability $(C)$, Opportunity $(O)$, and Motivation $(M)$. For the purposes of further analysis of the data, the three variables were combined into a single COM variable:

$$
C O M=1-[(C-3) / 12+(O-7) / 25+(M-3) / 12] / 3
$$

where the scale of each variable is shifted to zero and normalized to 1 so that their contribution has the same weight, and then the normalized sum value is inverted to produce the combined COM variable with values from 0 (worst) to 1 (best).

Variable B (behavior) was tested using two separate questions that represent connotations related to "My" versus "Our" energy behavior. It differs from the original COM-B construct presented in Figure 1 where only one behavioral indicator is foreseen. We took into consideration the uniqueness of the military culture where collective behavior and soldiers' psychological bond with his/her unit is manifested and adopted the COM-B model to the military context. "My" behavior (B1) was measured using a statement "I turn off the electricity when I stop using it". For "Our" energy behavior (B2) we used a statement that represents a commitment to unit's performance: "We manage energy well in the unit". All together these two statements created a We-I behavioral construct for measuring energy behavior in the military (Figure 3). These statements were measured using the Likert scale. Taking into consideration that COM-B model works in a context, we additionally tested an overall workplace satisfaction (see variable "S" in Figure 2) of the soldiers using one 10-point Likert scale question.

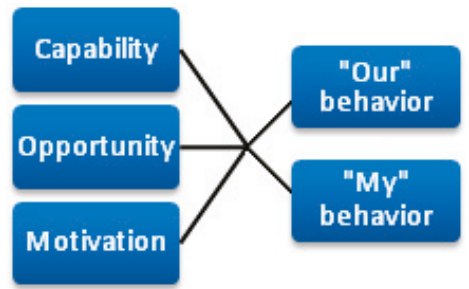

Figure 3. An extended construct of COM-B model for behavioral change in the military.

\section{Results}

Using the COM variable, we performed a series of tests for different groups of respondents at the 0.05 level of confidence. We found a statistically significant COM increase of $12 \%$ among those who had participated in some energy-saving initiatives $(C O M=0.64)$ versus the other group $(C O M=0.57)$, see Table 3. It is important to note that the number of those who had participated in energy-saving initiatives is relatively low and does not differ between the years.

Table 3. Comparison of Capability-Opportunity-Motivation (COM) values for different groups of respondents.

\begin{tabular}{ccccc}
\hline \multirow{2}{*}{ Category } & \multirow{2}{*}{ Description } & \multicolumn{3}{c}{ COM } \\
\cline { 3 - 5 } & & $\mathbf{2 0 1 8}$ & $\mathbf{2 0 1 9}$ & Total \\
\hline \multirow{2}{*}{ I participated in previous energy-saving activities } & Yes & 0.63 & 0.65 & 0.64 \\
& No & 0.57 & 0.56 & 0.57 \\
\hline \multirow{2}{*}{ I turn off electricity when I stop using it } & Yes & 0.59 & 0.58 & 0.59 \\
& No & 0.52 & 0.54 & 0.53 \\
\hline \multirow{2}{*}{ Service type } & Professionals & 0.60 & 0.60 & 0.60 \\
& Conscripts & 0.57 & 0.57 & 0.57 \\
\hline
\end{tabular}


Similarly, respondents who reported energy-saving behavior had a statistically significant $9 \%$ higher $C O M$ (average $C O M=0.59$ ) than their colleagues who do not exhibit energy-saving behavior (average COM $=0.53$ ). The results stand well with the COM-B theory where higher capabilities, opportunities and motivation influence a better behavior.

To determine the context of COM-B we measured how an overall satisfaction with the military service is influencing COM. The satisfaction (see Figure 4) measured from 1 (lowest) to 10 (highest) has a 0.49 correlation coefficient with the COM variable (at the 0.01 significance level). This is not surprising as we expected the satisfaction to be related with the motivation variable.

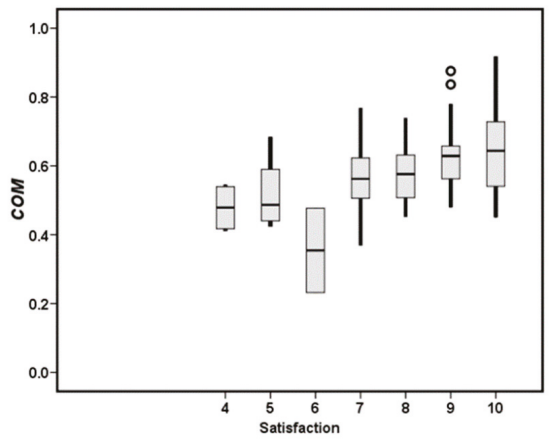

(a)

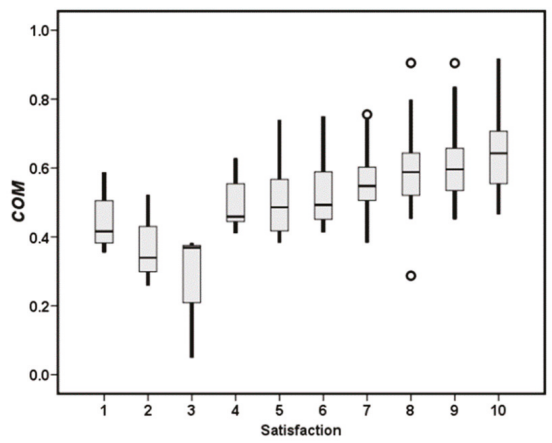

(b)

Figure 4. Interdependency between overall satisfaction with the service and the COM variable (Capability-Opportunity-Motivation) of: (a) professional soldiers, (b) conscripts.

Considering the uniqueness of our sample that consists of professional soldiers and conscripts we checked whether there are any differences between these two groups of respondents one year apart. There was no statistically significant difference in average $C O M$ value indicating independent groups of responders as a large part of the professional soldiers was rotated and all the conscripts were replaced over that year. Meanwhile, the $T$-test of independent samples suggested a statistically significant although quite small difference in energy-saving behavior between the professional soldiers and conscripts: the average COM value of professional soldiers $(0.60)$ exceeded the corresponding value of conscripts $(0.57)$ by $5 \%$.

In testing our main statement that COM is positively linked not only with individual soldier's behavior, but also with collective energy behavior of the unit, we measured the impact of the behavioral factors on an individual's behavior ("my" behavior) in relation to collective energy behavior of the unit ("our" behavior). For this reason, we split the respondents into 6 different subgroups based on their responses about their own behavior and the collective energy behavior of the unit. The groups and their corresponding COM values are presented in Table 4. The first column shows the energy-saving behavior of the unit as reported by a respondent: a plus sign is given when the respondent positively evaluated the collective energy behavior, a minus for the negatively reported behavior, and a zero when the respondent reported a neutral behavior. The second column has two values depending on whether the respondent herself/himself exhibits energy-saving behavior (either a plus or a minus). One-way analysis of variance (ANOVA) showed a significant difference in mean COM values between all groups. The results show a much stronger effect of COM value on "our" behavior than on "my" behavior.

Individually, each of the behavior variables positively correlates with the COM variable-the correlation coefficient is 0.45 for "our" behavior and 0.16 for "my" behavior. This can be observed in Figure 5, where the behavior becomes more positive as the COM variable grows. 
Table 4. COM values with "our" and "my" energy-saving behavior.

\begin{tabular}{ccc}
\hline "Our" Behavior & "My" Behavior & Mean COM Value \\
\hline+ & + & $0.6319^{1}$ \\
+ & - & $0.5691^{1}$ \\
0 & + & $0.5396^{1}$ \\
0 & - & $0.5305^{1}$ \\
- & + & $0.5199^{1}$ \\
- & - & $0.4319^{1}$ \\
\hline
\end{tabular}

${ }^{1}$ The mean difference is significant at the 0.05 level.

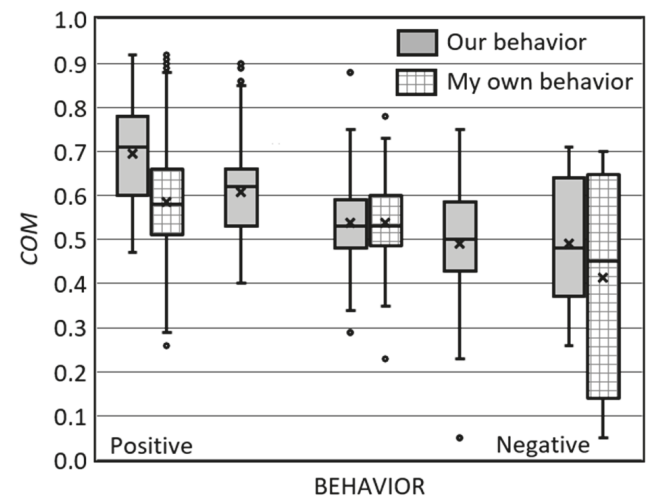

Figure 5. Capability-Opportunity-Motivation variable (COM) versus the self-reported energy-saving behavior of an individual (white hatched boxes-"my" behavior) and a group (grey boxes - "our" behavior).

\section{Discussion}

This study fills the gap in the research on military energy behavior and suggests that pro-environmental energy behavior in the military is linked not only with an individual soldier's attitudes and intentions, but also with its military unit. Institutionally favorable environment that forces military transition towards the pro-environmental energy behavior is reflected as a collective action. So far, many studies focused on technical solutions for reducing energy usage $[33,39,40]$ and enabling decision makers $[5,14,41]$ and individual soldiers $[10,24]$ to save energy. It appears that this research for the first-time underlines collectivity and connects individual and collective pro-environmental energy behavior into one measurable construct.

Pro-environmental energy behavior in the military should be considered in a special way as military culture penetrates attitudes and behavior $[26,28]$. Respectively, our conceptual construct that includes a collective energy behavior goes in line with other studies designed for communality in the military. Transformation from " $\mathrm{I}$ " to "We" is unique to the military as it serves as a protective psychological construct in difficult exercises and war situations [35]. According to our findings, in the case of pro-environmental energy behavior, this transformation makes a positive impact on both the collective and the individual behavior. These findings go in line with the findings where macro influences on energy behavior are discussed. According to the comprehensive review of studies about energy behavior in organizations, energy behavior is driven by broad social and institutional considerations [7,42]. In response to this statement, our research findings indicate that in the military unit communality acts as the factor of sustaining pro-environmental behavior, i.e., when the change factors decrease, the unit still exhibits a positive behavior even if individual's pro-environmental energy behavior might falter. 
The segregation of collective and individual behavior is a fundamentally new approach in COM-B model testing. These results can be explained by the fact that the COM-B model was not tested before in organizations or communities where communality (strong sense of belonging) is more important than individual contribution. At the same time, the results are consistent with research results from various fields in the military and shows that a collective identity becomes more important than an individual soldier's identity $[1,27,43]$. For example, the collective identity was found dominating in the research on military innovations [27], where a unique military culture was found manifesting. Similarly, studies on leadership in the military [44] are predominately concerned about the function of military leaders to create subordinates' emotional attraction to the organization which in turn increases commitment and resilience of soldiers.

Despite the segregation of the behavioral element, energy behavior in the military unit follows the classical COM-B model. Just like other researchers, we adopted the construct to the context of the organization. Thus, the results of this study resonate with the evidence of other studies using the COM-B model: the model is constructed with three statistically reliable indicators: capabilities, opportunities and motivation $[11,21,45]$. In addition, the overall variance of the variables compares to the other energy behavioral models (e.g., [15,46-48]).

Furthermore, our research goes in line with the findings of research that energy-saving behavior is a learned behavior [49]. In our study, those who participated in prior energy-saving initiatives reported a more positive energy-saving behavior. Energy behavior is a learned entity, thus prior experience increases the level of capability and splits energy users into groups according to this component. These findings are in line with the COM-B approach where the capability is one of three behavioral change factors $[11,45]$.

Although the results of this study test behavioral change factors of energy behavior at a military unit, certain limitations need to be considered. Firstly, the data was collected at a unit located in a fixed installation only. To overcome this limitation, data was collected twice for two consecutive years to level out the operational tempo at the unit. The relative consistency of behavioral data suggests that these differences are minimal.

Secondly, the behavioral indicators of individual and collective behavior are measured using only a few questions. This is since the questionnaire response time was shortened to $10 \mathrm{~min}$ so as not to distract soldiers from their tasks. Therefore, the behavioral indicator was measured only with two measures: one for the individual and one for the collective behavior. Separation of individual and collective behavior was not foreseen from the start of this study - it became evident only during the data analysis. Despite this limitation, the relationship between COM and behavioral factors is statistically strong. However, in future research, we suggest using several measures for individual and for collective behavior.

Based on this discussion, the research has a few practical implications:

For practitioners in the military, these results are interesting for gaining statistically tested model for pro-environmental energy behavior change. Our findings point out that pro-environmental energy behavior in the military unit follows the classic COM-B model with one exception: behavior (element B) is segregated into two components: collective and individual behavior. This revised model can be applied in practice and used to measure behavioral change when behavioral interventions are applied in the unit.

For practitioners in other than military organizations, this analysis demonstrates the duality of collective and individual factors in energy behavior. Our findings point to an importance of communality in the organization. Communality makes an impact on capability, opportunity, and motivation in pro-environmental energy behavior in an organization. Specifically, the findings indicate that in the organization with a strong sense of belonging, collective pro-environmental behavior remains active even if an individual behavior indicates low-involvement. 


\section{Conclusions}

This study addresses personal and collective factors emerging in energy behavior in a military unit. These are the main conclusions from the study:

First, collective and individual behavior has to be segregated while testing energy behavior in a military unit. The research findings justify this conceptual segregation and show that the dependence between the behavior change factors and the collective energy-saving behavior is pronounced more than the dependence between the factors of the individual's behavior. The segregation of collective and individual behavior is a fundamentally new approach when testing the Capability-Opportunity-Motivation-Behavior (COM-B) model.

Second, an extended COM-B model can be used while measuring pro-environmental energy behavior in the military. The model validation process led to a construct with three statistically reliable indicators representing the three independent $C O M$ variables. In this construct, the three indicators were formed of a different number of measures, respectively: Capability was defined by three levels of knowledge (I receive information, I know, I understand). Opportunity was defined by seven measures and composed the largest indicator in the construct. Motivation, composed of three measures, was the strongest component of the model.

Third, positive energy behavior is linked with an overall satisfaction with the military service. This finding indicates that the three COM-B model variables-Capability, Opportunity, and Motivation-need to be understood more broadly than only in conjunction with pro-environmental energy behavior. Motivation is the dominant variable of the COM-B model in this study and it is, therefore, linked with the satisfaction too. Military service satisfaction through motivation is said to influence energy behavior in the military unit.

Fourth, there is only a small difference in energy behavior between the professional soldiers and conscripts. This finding demonstrates that while collective behavior prevails over the individual one in the military unit, the time and nature of the military service does not make a significant impact on energy behavior. This confirms the theoretical statements that energy behavior is a learned entity and therefore, further research on energy behavior in military organizations should incorporate this insight.

Author Contributions: Conceptualization-R.S., A.J., G.L.; Data curation, A.J., G.L.; Formal analysis, R.S., A.J.; Investigation, R.S.; Methodology, G.L.; Writing-Original draft, R.S., A.J.; Writing-Review\& editing, A.J., G.L. All authors have read and agreed to the published version of the manuscript.

Funding: This research received no external funding.

Conflicts of Interest: The authors declare no conflict of interest.

\section{References}

1. Samaras, C.; Nuttall, W.J.; Bazilian, M. Energy and the military: Convergence of security, economic, and environmental decision-making. Energy Strategy Rev. 2019, 26, 100409. [CrossRef]

2. DFS. Environment Strategy. Available online: https://peacekeeping.un.org/sites/default/files/171116_dfs_ exec_summary_environment_0.pdf (accessed on 30 October 2019).

3. NATO. NATO's Role in Energy Security. Available online: https://www.nato.int/cps/en/natohq/topics_49208. htm (accessed on 30 October 2019).

4. A Roadmap for Sustainable Energy Management in Defence and Security Sector. Guidance Document 2017. Available online: https:/www.eda.europa.eu/docs/default-source/events/eden/phase-i/guidance/ consultation-forum-for-sustainable-energy-in-the-defence-and-security-sector---guidance-document.pdf (accessed on 30 December 2019).

5. Iftimie, I.A. Expeditionary energy economics (e3): The securitization of energy entrepreneurship during megacity counterinsurgencies (a NATO perspective). J. Innov. Entrep. 2018, 7, 4. [CrossRef]

6. Dudin, M.N.; Ivashchenko, N.P.; Gurinovich, A.G.; Tolmachev, O.M.; Sonina, L.A. Environmental entrepreneurship: Characteristics of organization and development. Entrep. Sustain. Issues 2019, 6, 1861-1871. [CrossRef] 
7. Pechancová, V.; Hrbáčková, L.; Dvorský, J.; Chromjaková, F.; Stojanovic, A. Environmental management systems: An effective tool of corporate sustainability. Entrep. Sustain. Issues 2019, 7, 825-841. [CrossRef]

8. Moumen, Z.; El Idrissi, N.E.A.; Tvaronavičienė, M. Water security and sustainable development. Insights Reg. Dev. 2019, 1, 301-317. [CrossRef]

9. Strielkowski, W.; Lisin, E.; Tvaronavičienè, M. Towards Energy Security: Sustainable Development of Electrical Energy Storage. J. Secur. Sustain. Issues 2016, 6, 235-244. [CrossRef]

10. Cerneviciutè, J.; Chichinato, O.; Piccinetti, L.; Raudsepp, M.; Roosalu, T.; Tvaronaviciene, M.; Zimmerman, K. Final Report of the Second Part of the Study Energy Efficiency: Cultural Change; Consortium: Minneapolis, MN, USA, 2016.

11. Michie, S.; Atkins, L.; West, R. The Behaviour Change Wheel: Guide to Designing Interventions, 1st ed.; Silverback Publishing: Sutton, UK, 2014.

12. Environment, Natural Resources and UN Peacekeeping Operations Greening the Blue Helmets United Nations Environment Programme. 2012. Available online: https://wedocs.unep.org/bitstream/handle/20.500.11822/ 8840/UNEP_greening_blue_helmets.pdf? sequence=3\&amp\%3BisAllowed= (accessed on 30 December 2019).

13. El Iysaouy, L.; El Idrissi, N.E.A.; Tvaronavičienè, M.; Lahbabi, M.; Oumnad, A. Towards energy efficiency: Case of Morocco. Insights Reg. Dev. 2019, 1, 259-271. [CrossRef]

14. Melchiorre, T. Recommendations on the Importance of Critical Energy Infrastructure (CEI) Stakeholder Engagement, Coordination and Understanding of Responsibilities in Order to Improve Security; NATO Energy Security Centre of Excellence (NATO ENSEC COE): Vilnius, Lithuania, 2018.

15. Tvaronaciene, M.; Slusarczyk, B. (Eds.) Energy Transformation Towards Sustainability, 1st ed.; Elsevier: Amsterdam, The Netherlands, 2019; ISBN 9-78012-817-6887.

16. Barker, F.; Atkins, L.; de Lusignan, S. Applying the COM-B behaviour model and behaviour change wheel to develop an intervention to improve hearing-aid use in adult auditory rehabilitation. Int. J. Audiol. 2016, 55, S90-S98. [CrossRef]

17. Smaliukienè, R.; Monni, S. A step-by-step approach to social marketing in energy transition. Insights Reg. Dev. 2019, 1, 19-32. [CrossRef]

18. Ojo, S.O.; Bailey, D.P.; Hewson, D.J.; Chater, A.M. Perceived Barriers and Facilitators to Breaking Up Sitting Time among Desk-Based Office Workers: A Qualitative Investigation Using the TDF and COM-B. Int. J. Environ. Res. Public Health 2019, 16, 2903. [CrossRef]

19. Crowley, J.; Ball, L.; Hiddink, G.J. Nutrition care by primary-care physicians: Advancing our understanding using the COM-B framework. Public Health Nutr. 2019, 1-12. [CrossRef] [PubMed]

20. Toblin, R.L.; Anderson, J.A.; Riviere, L.A.; McGurk, D.; Sipos, M.L. The Impact of Unit Membership on Smoking Among Soldiers. Mil. Med. 2016, 181, 16-20. [CrossRef] [PubMed]

21. Howlett, N.; Schulz, J.; Trivedi, D.; Troop, N.; Chater, A. A prospective study exploring the construct and predictive validity of the COM-B model for physical activity. J. Health Psychol. 2019, 24, 1378-1391. [CrossRef] [PubMed]

22. Costello, N.; McKenna, J.; Sutton, L.; Deighton, K.; Jones, B. Using contemporary behavior change science to design and implement an effective nutritional intervention within professional rugby league. Int. J. Sport Nutr. Exerc. Metab. 2018, 28, 553-557. [CrossRef] [PubMed]

23. Wilson, C.; Marselle, M.R. Insights from psychology about the design and implementation of energy interventions using the Behaviour Change Wheel. Energy Res. Soc. Sci. 2016, 19, 177-191. [CrossRef]

24. Maximising Energy Efficiency through Behaviour Change-A UK Case Study Why? Available online: https://www.eda.europa.eu/docs/default-source/events/eden/phase-i/information-sheets/cf-sedssinformation-sheet-maximising-energy-efficiency.pdf (accessed on 29 November 2019).

25. Atuel, H.R.; Castro, C.A. Military Cultural Competence. Clin. Soc. Work J. 2018, 46, 74-82. [CrossRef]

26. Meyer, E.G. The Importance of Understanding Military Culture. Acad. Psychiatry 2015, 39, 416-418. [CrossRef]

27. Adamson, W. Megacities and the US Army. Parameters 2015, 45, 45.

28. Petrauskaite, A.; Rusko, T. Recent Challenges of Institutional Identity and Contemporary Armed Forces. J. Secur. Sustain. Issues 2018, 7, 561-568. [CrossRef]

29. Tūtlys, V.; Winterton, J.; Liesionienè, O. Institutional aspects of competence-based integration of retired military officers into the civilian labour market. Pers. Rev. 2019, 48, 21-39. [CrossRef]

30. Novikovas, A.; Novikovienė, L.; Shapoval, R.; Solntseva, K. The Peculiarities of Motivation and Organization of Civil Defence Service in Lithuania and Ukraine. J. Secur. Sustain. Issues 2017, 7, 149. [CrossRef] 
31. Kormishkina, L.; Kormishkin, E.; Gorin, V.; Koloskov, D.; Koroleva, L. Environmental investment: The most adequate neo-industrial response to the growth dilemma of the economy. Entrep. Sustain. Issues 2019, 7, 929-948. [CrossRef]

32. Saritas, O.; Burmaoglu, S. Future of sustainable military operations under emerging energy and security considerations. Technol. Forecast. Soc. Chang. 2016, 102,331-343. [CrossRef]

33. Soni, A. Disruptive Energy Technologies and Military Capabilities. In Disruptive and Game Changing Technologies in Modern Warfare; Springer: Berlin/Heidelberg, Germany, 2020; pp. 115-134.

34. Smaliukiene, R. Sustainability issues in the military: Genesis and prospects. J. Secur. Sustain. Issues 2018, 8, 19-32. [CrossRef]

35. Langan, J.M. PTSD in Military Service Members Recommended Citation. Masthead Logo DePaul J. Health Care Law 2017, 19, 28.

36. Zou, H.; Chen, Y.; Fang, W.; Zhang, Y.; Fan, X. Identification of factors associated with self-care behaviors using the COM-B model in patients with chronic heart failure. Eur. J. Cardiovasc. Nurs. 2017, 16, 530-538. [CrossRef]

37. Williams, J.; Brown, J.M.; Bray, R.M.; Anderson Goodell, E.M.; Olmsted, K.R.; Adler, A.B. Unit cohesion, resilience, and mental health of soldiers in Basic Combat Training. Mil. Psychol. 2016, 28, 241-250. [CrossRef]

38. Cane, J.; Richardson, M.; Johnston, M.; Ladha, R.; Michie, S. From lists of behaviour change techniques (BCT s) to structured hierarchies: Comparison of two methods of developing a hierarchy of BCTs. Br. J. Health Psychol. 2015, 20, 130-150. [CrossRef]

39. Ganesan, A.U.; Nandhagopal, S.; Venkat, A.S.; Padmanaban, S.; Pedersen, J.K.; Chokkalingam, L.N.; Leonowicz, Z. Performance Analysis of Single-Phase Electrical Machine for Military Applications. Energies 2019, 12, 2285. [CrossRef]

40. Jiang, P.; Huang, S.; Zhang, T. Optimal Deception Strategies in Power System Fortification against Deliberate Attacks. Energies 2019, 12, 342. [CrossRef]

41. Kuril, J. Public administration for safe and secure environment: Case of Slovak Republic. Entrep. Sustain. Issues 2018, 5, 493-501. [CrossRef]

42. Andrews, R.N.L.; Johnson, E. Energy use, behavioral change, and business organizations: Reviewing recent findings and proposing a future research agenda. Energy Res. Soc. Sci. 2016, 11, 195-208. [CrossRef]

43. Le Foll, D.; Rascle, O.; Marchal, M.; Cabagno, G. Perceived motivational climate and unit cohesion: The case of French soldiers in training. Mil. Psychol. 2019, 31, 233-240. [CrossRef]

44. García-Guiu, C.; Moya, M.; Molero, F.; Moriano, J.A. El liderazgotransformacional y la potenciagrupalenunidadesmilitarespequeñas: El papelmediador de la identificación y cohesióngrupales. Rev. Psicol. Trab. Organ. 2016, 32, 145-152. [CrossRef]

45. Michie, S.; van Stralen, M.M.; West, R. The behaviour change wheel: A new method for characterising and designing behaviour change interventions. Implement. Sci. 2011, 6, 42. [CrossRef] [PubMed]

46. Pothitou, M.; Hanna, R.F.; Chalvatzis, K.J. Environmental knowledge, pro-environmental behaviour and energy savings in households: An empirical study. Appl. Energy 2016, 184, 1217-1229. [CrossRef]

47. Dumciuviene, D.; Cibinskiene, A.; Andrijauskiene, M. Determinants of Energy Saving: Evidence from a Vocational School in Greece. Energies 2019, 12, 3647. [CrossRef]

48. Paone, A.; Bacher, J.-P. The Impact of Building Occupant Behavior on Energy Efficiency and Methods to Influence It: A Review of the State of the Art. Energies 2018, 11, 953. [CrossRef]

49. Puttick, G.; Kies, K.; Garibay, C.; Bernstein, D. Learning and behavior change in a Girl Scout program focused on energy conservation: Saving energy to save the planet. J. Sustain. Educ. 2015, 8. Available online: http://www.jsedimensions.org/wordpress/wp-content/uploads/2015/01/Puttick-et-al-JSE-Vol-8-Jan2015.pdf (accessed on 30 December 2019). 
Article

\title{
The Peculiarities of Low-Cost Carrier Development in Europe
}

\author{
Jolanta Sabaityte ${ }^{1, *}$, Vida Davidavičiene ${ }^{1}$ and Gerard Frederick Van Kleef ${ }^{2}$ \\ 1 Department of Business Technologies and Entrepreneurship, Business Management Faculty, \\ Vilnius Gediminas Technical University, 10223 Vilnius, Lithuania; vida.davidaviciene@vgtu.lt \\ 2 Department of Traffic Analysis, Directorate of Railway Infrastructure, LG Infrastruktura LTD, \\ 02100 Vilnius, Lithuania; gerard-frederick.van-kleef@litrail.lt \\ * Correspondence: jolanta.sabaityte@vgtu.lt
}

Received: 15 October 2019; Accepted: 23 January 2020; Published: 3 February 2020

\begin{abstract}
Low-cost carriers (LCCs) have been growing by $11.4 \%$ in revenue passenger kilometers over 2017 and changed the airline industry radically. It drove down prices in the industry. Southwest Airlines (USA) designed the LCC blueprint model, and Ryanair copied it within Europe, followed by other airlines. This research aims to fulfill the gap in contemporary research upon LCC successfulness in Europe by a description of the current situation within Europe (2018 and January 2019) and the development issues it faced, which are mapped by the Ishikawa fishbone diagram. Furthermore, to rank the airlines on strength and vulnerability, The Technique for Order of Preference by Similarity to Ideal Solution (TOPSIS) methodology was used for meeting LCC characteristics and airline success. By comparison of meeting the LCC characteristics and the rank of the successfulness, the results of the TOPSIS analysis showed that the airlines meeting the most LCCs characteristics are seemingly less vulnerable to the development issues that airlines are facing, as Wizz Air and Ryanair are meeting most characteristics and are the most successful. Concluded is that airlines meeting the most LCC characteristics are the least vulnerable to current issues. However, major disruptions can still form an issue and limit growth. This research can be useful for comparing and positioning airlines in the market, based on issues and operational choices.
\end{abstract}

Keywords: low-cost carrier; development; airline industry; airline issues; transport industry; industry growth

\section{Introduction}

Low-cost carriers (LCCs) are a phenomenon that provided various people around the world access to air transportation with low prices, whereas in the past, aviation was known by its exclusivity for richer people and business travel. The airline industry has seen a big growth in its totality.

The number of passengers carried in 2017 grew by $7.2 \%$, whereas the revenue passenger kilometers (RPKs) on scheduled traffic in 2017 grew by 7.9\%. Also, freight transport by air grew in 2017. The freight tonne kilometers (FTKs) on scheduled flights grew 9.5\% [1].

The growth of the industry is ongoing since the last decline in 2009, with the number of passenger kilometers now approaching 8000 billion, whereas it used to be around 4500 billion in 2009 [2]. Besides the decline of 2009 and during other kinds of crises affecting the airline industry, it appears that the industry is growing exponentially in its overall trend after the end of World War II [1]. However, deregulations and freedom agreements are what caused the industry's growth in the first place. The Chicago Convention of 1944 led to a set of "freedoms" that are universal across the globe for providing international air travel. The first five freedoms are universal across the globe. The further four freedoms are provided only in special agreements [3]. Examples of deregulations and liberalization are the USA's Deregulation Act of 1978, the Open Skies Treaty between the European Union (EU), 
and the Single Skies of the EU that allowed competition to grow. It drove down prices and allowed (new) airlines to operate the routes they want.

So-called low-cost carriers with their total share of $30 \%$ of carried passengers on scheduled flights caused a big portion of this growth in the airline industry. Their growth in 2017 was $11.4 \%$, which is about 1.5 times the size of the growth of the total number of passengers $[1,4,5]$.

The growth of this type of airline is remarkable and getting attention around the world. Southwest Airlines in the United States of America (USA) and Ryanair in Europe are the most well-known LCCs around the world. Their ability to grow has different reasons while operating a similar business model. Whereas Southwest mainly operates in the USA, which gave the airline the advantage of a big country with lots of destinations within this country, Ryanair just started to grow after the deregulation of the British Islands and later the EU [4]. However, growth is, like in many cases, not without issues.

The purpose of this article is to identify significant factors that influence the development of LCCs in Europe in 2018, combined with the current status of the airlines. This research aims to find the issues and risks airlines face, to find out which airline currently has the best business model for being profitable and able to grow, and can, for this reason, be an example for LCC development in the environment of 2018 in Europe. It is a novelty since it describes the issues that airlines face in 2017 and 2018, and how they compared in 2018. Hence, some airlines changed their model or went through changes. Also, it limits the article to the issues of this current period and will not describe the effects of the economic crisis of 2008 or the terrorist attacks of 11 September 2001; e.g., LCCs have the most effect on the prices and different types of LCC that have been developed. The tasks done during this research are literature research on definitions, business models, development, and issues of LCCs, specifically in Europe, to gather data from airlines about successfulness and what typical characteristics of LCCs have or do not have. The statistical model, technique for order of preference by similarity to the ideal (TOPSIS), is used to compare the selected airlines with each other and to rank these airlines according to best performing on business success factors and meeting the most LCC requirements. Methods used in the research are literature analysis, information comparison, grouping, visualization by Ishikawa's fishbone diagram, and TOPSIS calculation.

\section{Low-Cost Carrier Definitions and Concepts}

Low-cost carriers are, in many cases, defined by what they offer. Different names are also not uncommon, where names such as low-fare airlines [5], discount carriers [6], "price fighters" [7] and no-frills airlines [8] are used. However, the most generally accepted name is low-cost carrier [2], since it is the given name by the main organizations in the airline industry. The most common definition is "an air carrier that has a relatively low-cost structure in comparison with other comparable carriers and offers low fares or rates" [2]. Another one is, "Although marginally different, most researchers define LCCs as carriers which, through a variety of operational processes, have achieved a cost advantage over full-service carriers (FSCs)" [9].

The definition of the International Aviation Organization (2004) is similar to the one of Schlumberger and Weisskopf (2014) but is not pointing to other types of airlines.

Airlines make their own strategic and operational choices based on what they want to achieve. Low-cost carriers aim to have the lowest costs so that they can provide the lowest fares when the customer only pays for the basic product, which is transportation. All the other "frill" services, like the provided food or allowed checked-in luggage, must be paid for now [10]. According to Dennis (2007), this can speed up the turn-around of aircraft at airports, since aircraft do not need to be cleaned and catered at every airport. This will allow airlines to use their aircraft for more flights per day. As mentioned in the definitions above, it is to achieve a customer's preference for them because of the cost advantage. However, every LCC makes its own decisions. However, there are some models of low-cost carriers to distinguish. In the first place, there are the "pure LCCs," sometimes also referred to as ultra-low-cost carriers (ULCCs) [11]. This type of airline has to meet certain requirements in the research. These are: 
1. Fleet homogeneity;

2. Single-class cabin;

3. Secondary airport;

4. Direct sales only;

5. No complimentary in-flight service with lowest fare category;

6. No complimentary in-flight service with highest fare category;

7. No free checked baggage with lowest fare category;

8. No free checked baggage with highest fare category;

9. No frequent flyer program;

10. Point-to-point services only;

11. No code-sharing;

12. One-way fares only;

13. No more than one fare at any time;

14. No more than two fares at any time [11].

Doganis (2009) [12] named point-to-point connections, uniform fleet, use of secondary airports, direct sales of tickets, one-way fares, and no-frills in services as typical characteristics. Klophaus, Conrady, and Fichert split fare categories in their requirements mentioned above, Besides the criteria mentioned above, the success of the airline can be assessed by some more, such as Earnings Before Interest, Taxes, Depreciation and Amortization (EBITDA) margin of the airline and load factor [13]. Airlines tend to have their growth ratio over the year in their annual reports [14].

Klophaus, Conrady, and Fichert (2012) also distinguished models of LCCs in their report, where they placed the LCCs in categories based on the number of criteria they met. These are:

- "Pure low-cost carriers," meeting at least 11 out of the 13 criteria;

- " "Hybrid carrier with dominating LCC characteristics," between eight and 10 criteria;

- "Hybrid carrier with dominating full-service airline characteristics," between five and seven criteria;

- "Full-service carriers," 0 to four criteria. [11].

Given the rapid changes that the airline industry is going through, such as the earlier mentioned rapid growth, aircraft, and business development, the ideas of Klophaus, Conrady, and Fichert (2012) [13] are not completely relevant anymore for the situation in 2018. Some of the assessed airlines are not existing anymore or changed their business model. Recently, the Latvian airBaltic announced a switch over to a full Airbus A220-300 series fleet of at least fifty aircraft with options for 30 more aircraft [15]. But for example, as Klophaus, Conrady, and Fichert (2012) mentioned, this aircraft-type did not even exist. Additionally, the profitability and growth of the airlines in the research of Klophaus, Conrady, and Fichert (2012) are not taken into account since their focus was on characteristics.

The definitions and concepts are described above. However, airlines make their own decisions regarding their strategy and fleet. Some of these strategic decisions influence eventual sensitivity for some of the issues the airline industry can face, such as high oil prices. An assessment of meeting LCC criteria and successfulness of the airline (in EBITDA margin, growth, fleet size, and aircraft on order number of destinations) is done. Before this assessment, authors described the issues that airlines faced over the last year so that later authors could evaluate different strategies by the success and the possible effects of the issues in the industry.

\section{Issues Faced by Low-Cost Carriers from 2017 until December 2018}

The LCCs have been growing fast in Europe, and the whole airline industry has grown too. Besides growth and positive developments, there are also risks in the industry. It is important to identify the issues that can become risks to airline sustainability. In this research that is chosen for the years 2017 and 2018, the authors could identify the most recent issues. It is also a limitation so 
that "former" issues, such as effects of economic crises or terrorist attacks, are not taken into account, as mentioned in the introduction. This analysis was conducted by literature research that was later summarized and structured by using the method of the Ishikawa diagram [16].

LCCs faced issues in these years. Most notably have been the strikes at Ryanair, where pilots are striving to have a better salary, good base locations, and working hours. It caused cancellations and lots of damage to the reputation of the airline. Ryanair keeps on growing but gave a profit warning to its shareholders [17]. Ryanair started giving in to the desires of some of the labor unions. Ryanair's problems seem to stay by just the company itself [18]. It is one of the examples why it is important to point out briefly what the issues were, and the reasons for the issues.

Monarch, Air Berlin, and Primera Air went to bankruptcy recently [19]. Primera Air, as the most recently fallen airline, filed for bankruptcy, while it just started operating new aircraft and new routes. However, the airline was not prepared to withstand the losses it made. New aircraft deliveries caused the airline to lease other aircraft, but since they promised their low prices, it got into trouble. The leasing costs of the other aircraft were very high, most likely since the airline had to do it in the middle of the summer [20].

Air Berlin lost its main investor and was doomed to file for bankruptcy. Air Berlin tried to brand itself as LCC, but it was more an FSC with a few LCC characteristics [11]. After years of losses, Etihad stopped investing in the airline, which meant that Air Berlin had to carry the losses by itself [21].

Another factor that can be an issue in the future is the limited capacity available. The capacity is that some of the airports are getting close to their maximum capacity, like Amsterdam Schiphol Airport [22]. Given that the airports are located close to the cities in most cases, space to expand can be limited. This means that a slot on these airports is getting more expensive by the lack of supply. However, the demand for air transportation of passengers is increasing, since globalization is still ongoing. Growth within the air freight market is also noticeable. This will tighten the airports even more in their number of slots [23].

One other issue, which is universal for all the airline industry, is the oil price. Fuel is the highest cost for an airline, followed by personnel cost. However, the airlines found a way to limit the fluctuation by hedging the costs. The real issue is the hedging itself. Due to the continuous fluctuation of the oil price, it can be that the hedged price for the fuel can lead up to higher costs than necessary when the prices go down [24]. However, LCCs seem to be less affected due to their younger, more efficient fleet than FSCs [25].

Flight taxes can put a hold on growth and low prices. Ryanair is known for its really low prices from around $10 €$. This situation is becoming more difficult when a country implements a flight tax with a fixed number of euros. Some countries implemented flight taxes based on distance. This tax affects traffic patterns, where airlines need to adjust. For an airline, taxes can be a reason why some destinations are not interesting to fly to [26].

The described issues above seem to be coming from different categories, which may be grouped into personnel, machines, material, and environment, according to Ishikawa's original fishbone diagram [16]. In this research, the Ishikawa diagram is used as a tool to map the issues of the airline industry into the factors that affect the airline industry. Ryanair went into a labor dispute with its pilots, which led to strikes (personnel). After a short life as an LCC, Primera Air filed for bankruptcy since the supplier of aircraft, Airbus, was late with their delivery (machines). Primera Air already planned forward on having these aircraft, so they had to find replacement lease aircraft to carry out their promised services. This led to their fate of filing for bankruptcy. It shows how difficult it can be to enter the market and to maintain the position. Air Berlin had to file for bankruptcy after the stop of investments from Etihad Airways (material), and airlines had to deal with higher fuel prices (material). Slot problems are mainly due to a lack of capacity at airports or limitations in slots (environment). The causes led to the development issues are summarized by the following diagram (Figure 1), according to the model of Ishikawa [16]. 


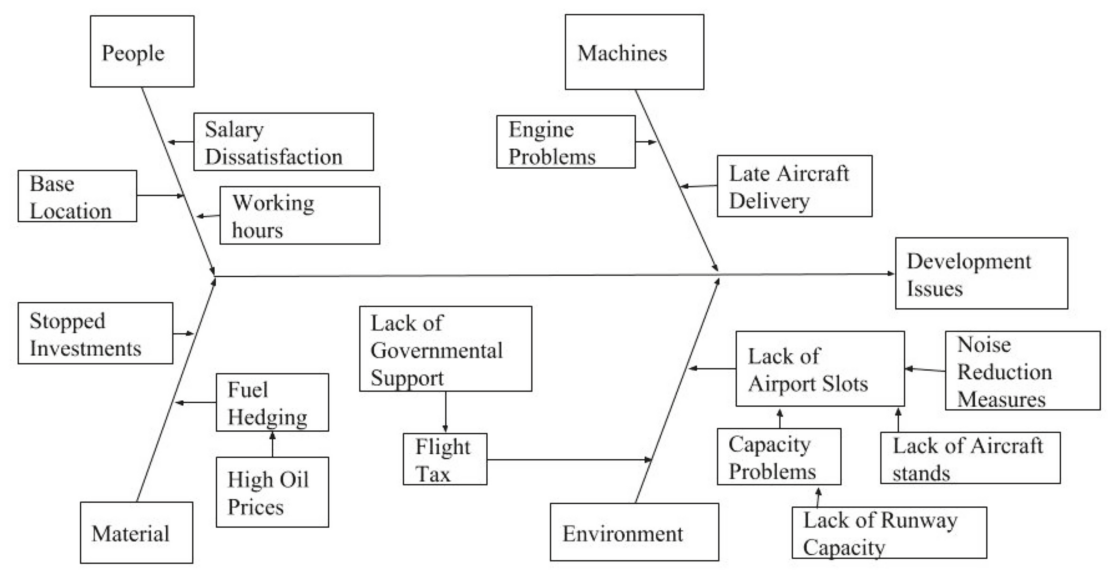

Figure 1. Ishikawa diagram of the airline development issues. Source: compiled by authors based on issues described in the article.

In Figure 1, it is visible that there are four different types of (development) air transport issues that can be encountered by low-cost carriers within the period from 2017 and 2018, and can lead to development issues. There is, for example, a period of economic growth, where the countries in the EU had an average growth of $2.8 \%$ [27]. However, this means that airlines need to be able to grow in a time when there is economic growth [28]. An assessment of airlines is based on the need for airlines performance analysis following the LCC criteria. The airlines all can face some of the issues mentioned above, in the future, or face these issues already; for that reason, it is necessary to see how their business model has succeeded. In order to analyze the successfulness of the business model, it is necessary to research which characteristics of LCCs the airlines meet.

\section{Methodology}

This research aims to give an overview of the airline industry's issues regarding the growth, development, and sustainability of the airline industry. This is combined with how airlines are currently performing and what LCC criteria they meet, so that can be compared generally in which airlines can sustain future issues.

The structure of the research consisted of five processes, as shown in Figure 2. The processes were supplied with information through input from literature, annual reports, and databases. Analysis of the literature revealed the definition of LCCs and describes the issues faced in the airline industry, and forms a list for the main characteristics of LCCs. The issues faced were mapped into the Ishikawa diagram, where the issues were grouped by the affected factors of the airline process. The main characteristics of the LCCs provide input to the first TOPSIS, which compares the business models of the airlines on how they are meeting the listed LCC-characteristics. Annual reports and data from databases form the input of the second TOPSIS, which focused on growth, EBITDA, and efficiency of the airline. The output of both TOPSIS processes were mapped into a quadrant diagram, which shows how the airlines are meeting the characteristics and how successful they are. 


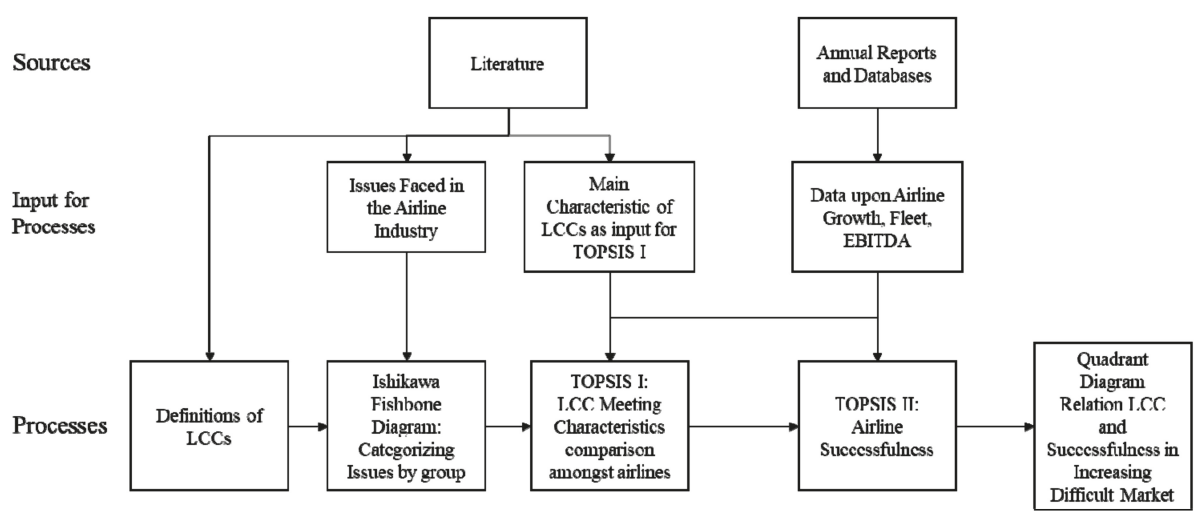

Figure 2. Diagram of research structure. Compiled by the authors.

The airline development issues described above were put into an Ishikawa diagram (see Figure 1) for providing an overview. For an airline, it is then important to see how it can withstand some of the issues, and what can be affecting the airlines. For example, The International Air Transport Association (IATA) (2018) says that airlines try to counter the fuel price increase not only with fuel hedging but with fuel efficiency provided by new, efficient aircraft. Therefore, an airline has a low average fleet age, preferably. Moreover, airlines that mainly fly to secondary airports generally have more space to grow there than at a major European hub. Therefore, it is important to see how the airlines operate and what their success is in the environment of 2017 (financial results, yearly averages) and 2018 (fleet characteristics, operating model). What can be seen from IATA's statement is that multiple criteria have to be met by an airline to withstand issues in the industry. Focus is on how well the airlines are meeting the criteria of the operating model of an LCC, which is combined with a criteria analysis upon the airlines' success.

The methodology used to assess if the airline is meeting the LCC definition criteria and the LCC development's success is the technique for order preference by similarity to the ideal solution (TOPSIS) from where the outcome leads to a ranking of alternatives, in this case, the airline's business model. The assessment exists of different criteria and numbers and it can, therefore, be seen as fuzzy data analysis. This needs to be approached by a multiple criteria decision method (MCDM). Normally, TOPSIS is meant for ranking alternatives in decisions, but it can be used for ranking models, too. Hence, the TOPSIS method was based on a set of criteria and situations. TOPSIS is preferred over simple additive weighting since it can handle negative data in its calculations. This is required since airlines can decline, make losses, and sell aircraft. Based on the fuzzy dataset, the methodology TOPSIS was chosen to rank the airlines to identify the successful airlines in the market. This led to an output that shows if meeting LCC criteria can lead to more successfulness and lower vulnerability. The two rankings were presented together in a quadrant diagram. In Table 1, the criteria used in the two TOPSIS analyses in Tables 2-5 are presented. In this way, the split was done between the earlier mentioned criteria [29].

The TOPSIS analysis was based on retrieved data regarding meeting the LCC criteria, as well as the airlines' successfulness in growth (in passengers), efficiency (seat occupancy, fleet age), and EBITDA. The data used for the analyses are presented below in Tables 2 and 4 . This was the input to the TOPSIS calculations on meeting the LCC requirements in Table 2 and the success in Table 4. TOPSIS requires normalized data for the statistics, so the numbers in the table needed to be normalized by the following formula [29]:

$$
N_{i j}=\frac{X_{i j}}{\sqrt{\sum_{i=1}^{m} X_{i j}^{2}}},
$$


where $N$ is the normalized number, $X$ is the given number, $i$ is the value of the alternative in relation to the criterion, and $j$ marks the criterion involved in the calculation.

Since TOPSIS is based on weights, the normalized numbers in the table were multiplied by the assigned weight given for the concerned criterion. After this multiplication, the highest and the lowest numbers were visible. After this, the positive and negative ideal per criterion were calculated. Before this, what is positive and negative needed to be established. A high EBITDA margin is positive, but a high average fleet age is negative. The following formula was used to calculate the positive and negative ideal [29]:

Positive:

$$
V^{+}=\left(V_{1}^{+}, V_{2}^{+}, \ldots, V_{n}^{+}\right)=\left(\left(\frac{\max _{i} i j}{j \in J i}\right)\left(\frac{\min _{i} i j}{j \in J i}\right)\right)
$$

Negative:

$$
V^{-}=\left(V_{1}^{-}, V_{2}^{-}, \ldots, V_{n}^{-}\right)=\left(\left(\frac{\min _{i} i j}{j \in J i}\right)\left(\frac{\max _{i} i j}{j \in J i}\right)\right)
$$

where $V^{+}$is the positive ideal and $V^{-}$is the negative ideal.

When the positive and negative ideals per criterion were calculated, the TOPSIS method proceeded with the calculation of the distance of each alternative to the positive and negative ideal. In this case, each airline's normalized weighted number for each criterion was compared to the positive and negative ideal by using the following formulas:

Distance to Positive:

$$
S_{i}^{+}=\sqrt{\sum_{j=1}^{n}\left(V_{i j}-V_{j}^{+}\right)^{2}}
$$

Distance to Negative:

$$
S_{i}^{-}=\sqrt{\sum_{j=1}^{n}\left(V_{i j}-V_{j}^{-}\right)^{2}}
$$

where $S_{i}{ }^{+}$is the distance to the positive ideal solution and $S_{i}^{-}$is the distance to the negative ideal solution.

The goal of the application of the TOPSIS was to provide an order preference for similarity to the ideal solution. In this case, it is how the airlines are meeting the LCC criteria and how successful the airlines are, as mentioned in Table 1. For this final calculation, this formula was used [29]:

$$
P_{i}=\frac{S_{i}^{-}}{S_{i}^{-}+S_{i}^{+}}
$$

where $P_{i}$ is the biggest similarity to the negative solution.

The closest result to a value of one is the most similar to the best solution, which in this research is the airline that meets the highest number of LCC criteria and that is the most successful in terms of profitability, growth, network size and fleet age. The closest to 0 is the most similar to the worst solution, which is a vulnerable airline for eventual issues that occur, which means an airline can have an old fleet or is making losses at the moment. TOPSIS is a method to compare alternatives based on criteria [29]. In this research, airlines form the "alternatives."

The LCC criteria mentioned by Doganis (2009) and airlines was assessed by Klophaus, Conrady, and Fichert (2012). Miranda, Baltazar, and Silva (2016) formed the base for the analysis of success. The EBITDA margin was chosen since this provides the operating profit margin, not including taxes, interests, or depreciation and amortization of the airline of the revenue they make [13]. It was also chosen since it does not include taxation since that can be different in each country. 
Table 1. Criteria for TOPSIS analysis.

\begin{tabular}{|c|c|}
\hline Criteria TOPSIS LCC Criteria & Criteria TOPSIS Successfulness \\
\hline $\begin{array}{l}\text { The ratio of aircraft of the same type, measured by dividing the } \\
\text { biggest group of aircraft in the fleet by the total fleet }(\mathrm{C} 1)\end{array}$ & $\begin{array}{l}\text { Aircraft on order and in memoranda of } \\
\text { understanding (as of } 1 \text { December 2018) (C12) }\end{array}$ \\
\hline $\begin{array}{l}\text { Rather using airports ranked as secondary airports, avoid } \\
\text { flying to Paris Charles de Gaulle and London Heathrow }(\mathrm{C} 2)\end{array}$ & Average fleet age (as of 1 December 2018) (C13) \\
\hline $\begin{array}{l}\text { Direct sales of the airline tickets via the airline's own website is } \\
\text { the most common (C3) }\end{array}$ & Number of destinations (C14) \\
\hline One-way fare tickets are the main way to sell tickets (C4) & $\begin{array}{l}\text { The profitability of airline } \\
\text { (EBITDA margin in \%) (C15) }\end{array}$ \\
\hline $\begin{array}{l}\text { No usage of jet bridges (unless required) (C5) } \\
\text { No included onboard services on Short-haul (C6) } \\
\text { No frequent flyer program (C7) }\end{array}$ & Average load factor of 2017 in \% (C16) \\
\hline No free checked baggage (C8) & Average growth/decline figure \\
\hline No code sharing (C9) & over 2017 in \% (C17) \\
\hline No cargo license (C10) & \\
\hline $\begin{array}{l}\text { No guaranteed connections to another flight (of the carrier } \\
\text { itself or cooperating airlines) (C11) }\end{array}$ & \\
\hline
\end{tabular}

All the criteria mentioned were based on the definitions given on what a real LCC or ULCC should be like. Since defining a secondary airport is hard, it was chosen to have a limited look at the airports serving Europe's two most populated functional urban areas, which are London and Paris [30]. Airlines can differ from them in their strategy. However, in that way, they were not meeting the real definitions or requirements. Definition criteria were equally weighted, whereas successfulness criteria, i.e., profitability, growth, and the number of destinations offered were given a higher weight. It was based on an assumption of what is important.

Klophaus, Conrady, and Fichert (2012) assessed 20 airlines for their simple LCC index, based on the 20 largest LCC, ranked by capacity [31]. Some of these airlines no longer exist. Other airlines focus on one country, rather than having bases in more countries. Within this research, the airlines Ryanair, easyJet, Eurowings, Norwegian, Vueling, Wizz Air, airBaltic, and Transavia were chosen based on the following factors:

- $\quad$ Named as LCC by Deutsches Zentrum für Luft- und Raumfahrt (2010);

- Flying with aircraft that are capable of carrying at least 130 passengers;

- Bases in more than one EU country;

- $\quad$ Still active on 20 November 2018;

- Assessed on winter schedule 2018-2019.

The quadrant diagram shows the positions of the different airlines regarding successfulness and meeting the LCC criteria. The axes are successful, vulnerable (vertical), and "hybrid carrier/FSC or True" LCC. The quadrants wherein the airlines can be located:

- $\quad$ True LCC, successful;

- True LCC, vulnerable;

- Hybrid carrier/FSC, successful;

- Hybrid carrier/FSC, vulnerable.

This shows how the different operating models of the airlines can lead to successfulness.

\section{Results-Data Gathering and Processing by Applying TOPSIS}

For the assessment in TOPSIS, whether airlines are meeting LCC requirements, it is important to systemize the knowledge and to construct the table. In the case of yes-or-no answers to the question, if a requirement is met, then the answer will be 1 (yes) and 0 (no). Fleet similarity (as of 30 November 2018) and the different LCC characteristics are described in Table 2. Wizz Air, Transavia, and Vueling are 
the only airlines that operate a complete one-type fleet of only Airbus A320-family- and Boeing 737-family-type aircraft. Operating a one-type fleet is one of the main characteristics of an LCC and provides several operational benefits in maintenance, training, and flexibility [11]. The data of flying from London Heathrow and or Paris Charles de Gaulle shows that only three of the eight airlines avoid these airports [32]. By browsing for a flight from each assessed airline, the main booking option via the airline's website was ranking the highest with the best price offer. The flights used for this research were:

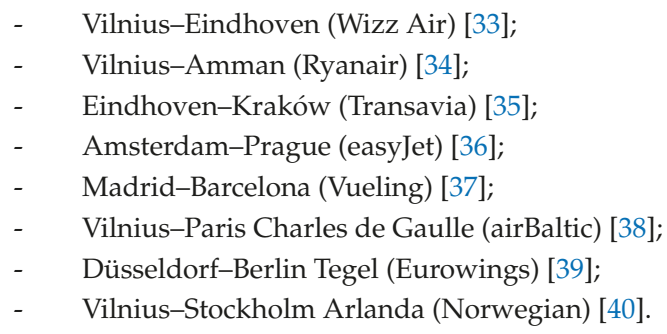

Skyscanner is a neutral website that aims to discover the lowest prices on flights, and the cheapest options for the flights were in the first place in the offers for the same flight. Eurowings, Vueling, and Transavia flights are also code-sharing, mainly with (partners of) their parent companies, such as Lufthansa Group, IAG, and Air France-KLM.

Via the airline websites, it became clear that every airline first provides the one-way services, and showed the frequent flyer programs [41-48]. In the case of Eurowings, Vueling, and Transavia, it is the same as their parent company. The analysis of airline website contents also revealed that food and drinks are not available "for free" on short- and medium-haul flights of the airlines. Ryanair and easyJet changed their business model slightly $[49,50]$. They started providing connections and cooperation with other long-haul carriers. This is part of changed and adjusted strategies.

Table 2. Input for TOPSIS LCC criteria. Source: compiled by the authors.

\begin{tabular}{cccccccccccc}
\hline Criteria & $\begin{array}{c}\text { C1 } \\
{[50]}\end{array}$ & $\begin{array}{c}\text { C2 } \\
{[51]}\end{array}$ & $\begin{array}{c}\text { C3 } \\
{[33-40]}\end{array}$ & $\begin{array}{c}\text { C4 } \\
{[41-48]}\end{array}$ & $\begin{array}{c}\text { C5 } \\
{[52-59]}\end{array}$ & $\begin{array}{c}\text { C6 } \\
{[41-48]}\end{array}$ & $\begin{array}{c}\text { C7 } \\
{[41-48]}\end{array}$ & $\begin{array}{c}\text { C8 } \\
{[41-48]}\end{array}$ & $\begin{array}{c}\text { C9 } \\
{[33-40]}\end{array}$ & $\begin{array}{c}\text { C10 } \\
{[60]}\end{array}$ & $\begin{array}{c}\text { C11 } \\
{[41-50]}\end{array}$ \\
\hline Weight & 0.091 & 0.091 & 0.091 & 0.091 & 0.091 & 0.091 & 0.091 & 0.091 & 0.091 & 0.091 & 0.091 \\
Wizz Air (W6) & 1.000 & 1 & 1 & 1 & 1 & 1 & 1 & 1 & 1 & 1 \\
Ryanair (FR) & 0.994 & 1 & 1 & 1 & 1 & 1 & 1 & 1 & 1 & 1 \\
Transavia (HV) & 1.000 & 1 & 1 & 1 & 0 & 1 & 0 & 1 & 0 & 0 & 0 \\
easyJet (U2) & 0.997 & 0 & 1 & 1 & 0 & 1 & 1 & 1 & 1 & 1 \\
Vueling (VY) & 1.000 & 0 & 1 & 1 & 0 & 1 & 0 & 1 & 0 & 0 \\
airBaltic (BT) & 0.400 & 0 & 1 & 1 & 0 & 1 & 0 & 1 & 0 & 0 \\
Eurowings (EW) & 0.748 & 0 & 1 & 1 & 0 & 1 & 0 & 1 & 0 & 0 \\
Norwegian (DY) & 0.802 & 0 & 1 & 1 & 0 & 1 & 0 & 1 & 0 & 0 \\
\hline
\end{tabular}

The data in Table 2 and the result of the calculation in Table 3 prove that Wizz Air is meeting all the LCC requirements, whereas airBaltic is meeting only the ones that every researched airline is meeting. Wizz Air is in this way ranking first, followed by Ryanair and easyJet, that both started following some different principles in the time between the publication of Klophaus, Conrady, and Fichert (2012) and today. Wizz Air is, according to this research, the single "true" LCC. The TOPSIS calculations in Tables 4 and 5 show which airline is the most successful, both financially and in terms of growth. The calculation towards the results in Table 3 can be found in Appendix A.

The data presented in Table 4 show that all of the airlines grew in 2017. This varied between $6.5 \%$ and $77 \%$. However, the $77 \%$ for Eurowings was caused by the acquisition of the remains of the fallen Air Berlin [61]. The most noticeable data in Table 3 are the aircraft on order by Wizz Air, the complete fleet replacement by airBaltic, the high load factor, and the high EBITDA margin of Ryanair. Norwegian is the only airline in this research that reported a loss, which means that its operating costs are exceeding the revenue made. All of the data upon the criteria are placed in Table 4 . In Table 5 the 
results of the calculations can be found, whereas the calculations of the successfulness can be found in Appendix B.

Table 3. Results of TOPSIS LCCcriteria. Source: compiled by the authors.

\begin{tabular}{ccccc}
\hline Airline & $\boldsymbol{S}_{\boldsymbol{i}}{ }^{+}$ & $\boldsymbol{S}_{\boldsymbol{i}}{ }^{-}$ & $\boldsymbol{P}_{\boldsymbol{i}}$ & Rank \\
\hline Wizz & 0 & 0.15 & 1 & 1 \\
Ryanair & 0.091 & 0.122 & 0.573 & 2 \\
Transavia & 0.141 & 0.06 & 0.287 & 4 \\
easyJet & 0.123 & 0.090 & 0.421 & 3 \\
Vueling & 0.151 & 0.022 & 0.126 & 6 \\
airBaltic & 0.150 & 0 & 0 & 8 \\
Eurowings & 0.151 & 0.013 & 0.077 & 7 \\
Norwegian & 0.144 & 0.048 & 0.249 & 5 \\
\hline
\end{tabular}

Table 4. Input for successfulness TOPSIS. Source: compiled by the authors, see footnotes.

\begin{tabular}{|c|c|c|c|c|c|c|}
\hline Criteria & $\begin{array}{c}\text { C12 } \\
{[62-69]}\end{array}$ & $\begin{array}{l}\text { C13 } \\
{[61]}\end{array}$ & $\begin{array}{c}\text { C14 } \\
{[15,70-77]}\end{array}$ & $\begin{array}{c}\mathrm{C} 15 \\
{[14,59,69,78-82]}\end{array}$ & $\begin{array}{c}\mathrm{C}^{1} \mathbf{1}^{1} \\
{[14,59,69,78-82]}\end{array}$ & $\begin{array}{c}\mathrm{C} 17^{2,3} \\
{[14,59,69,78-82]}\end{array}$ \\
\hline Weight & 0.1 & 0.05 & 0.15 & 0.4 & 0.1 & 0.2 \\
\hline Wizz Air & 257 & 4.7 & 146 & 14.1 & 91.2 & 24 \\
\hline Ryanair & 135 & 6.9 & 243 & 20 & 95.3 & 10.3 \\
\hline Transavia & 0 & 8.2 & 115 & 5.6 & 90.6 & 11 \\
\hline easyJet & 147 & 7.3 & 163 & 8.1 & 92.9 & 10.2 \\
\hline Vueling & 45 & 7.2 & 112 & 12.7 & 84.7 & 6.5 \\
\hline airBaltic & 36 & 9.4 & 70 & 5.8 & 76 & 22 \\
\hline Eurowings & 4 & 11.1 & 137 & 2.3 & 79.91 & 771 \\
\hline Norwegian & 116 & 3.9 & 161 & -5.75 & 87.5 & 13 \\
\hline
\end{tabular}

${ }^{1}$ Ryanair, easyJet, and Wizz Air work with a broken fiscal year (FY). The profit margin given is the one of FY that covered the most of 2017. ${ }^{2}$ Eurowings is put in the same group as Brussels Airlines in Lufthansa Group's Annual Report. The load factor given in this table is the one of Eurowings and Brussels Airlines combined. ${ }^{3}$ Eurowings grew by $77 \%$, mainly due to Lufthansa group's acquisition of the parts of Air Berlin.

Table 5. Results successfulness TOPSIS. Compiled by the authors.

\begin{tabular}{ccccc}
\hline Airline & $\boldsymbol{S}_{\boldsymbol{i}}^{+}$ & $\boldsymbol{S}_{\boldsymbol{i}}{ }^{-}$ & $\boldsymbol{P}_{\boldsymbol{i}}$ & Rank \\
\hline Wizz Air & 0.149 & 0.276 & 0.650 & 2 \\
Ryanair & 0.158 & 0.346 & 0.687 & 1 \\
Transavia & 0.258 & 0.150 & 0.368 & 7 \\
easyJet & 0.225 & 0.189 & 0.457 & 4 \\
Vueling & 0.204 & 0.243 & 0.544 & 3 \\
airBaltic & 0.243 & 0.156 & 0.391 & 6 \\
Eurowings & 0.247 & 0.195 & 0.441 & 5 \\
Norwegian & 0.372 & 0.052 & 0.122 & 8 \\
\hline
\end{tabular}

From this TOPSIS calculation and its result in Table 5, it can be concluded that Ryanair has the highest rank, whereas Norwegian is ranked last. This ranking tells that Ryanair is the best performing LCC, by being the most similar to the positive ideal solution, which is a growing, profitable, (fuel-) efficient airline. This is mainly caused by its high EBITDA, as well as a young, nearly single-type fleet of aircraft, as well as its high seat occupancy. Newer aircraft are more fuel efficient and have a single-type fleet that allows the company to save on crew (all the crew able to operate all the aircraft in the fleet) and maintenance costs (the maintenance crew only needs to have knowledge on one aircraft type and the airline does not need to maintain a stock of different aircraft types). High seat occupancy is a key performance indicator for airlines since this determines how well the provided capacity is used to create revenue. Norwegian is the only airline making a loss amongst this group and had to sell new aircraft to pay bills. Noticeable is that the "subsidiary LCCs," such as Eurowings, Vueling, 
and Transavia, are not amongst the highest in meeting LCC criteria and also not in the successfulness TOPSIS. A probable reason for this is that they mainly operate out of main airports, operate an older fleet, and have lower load factors than the airlines that are meeting more LCC criteria. The older fleet can cause less efficient aircraft and higher vulnerability when the oil price rises. In Figure 3, the data presented shows how the airlines compare to each other, based on the overall score on both TOPSIS analyses. Wizz Air and Ryanair are the least vulnerable to the industry's problems, given their successfulness and growth (perspectives). Norwegian is the most vulnerable.

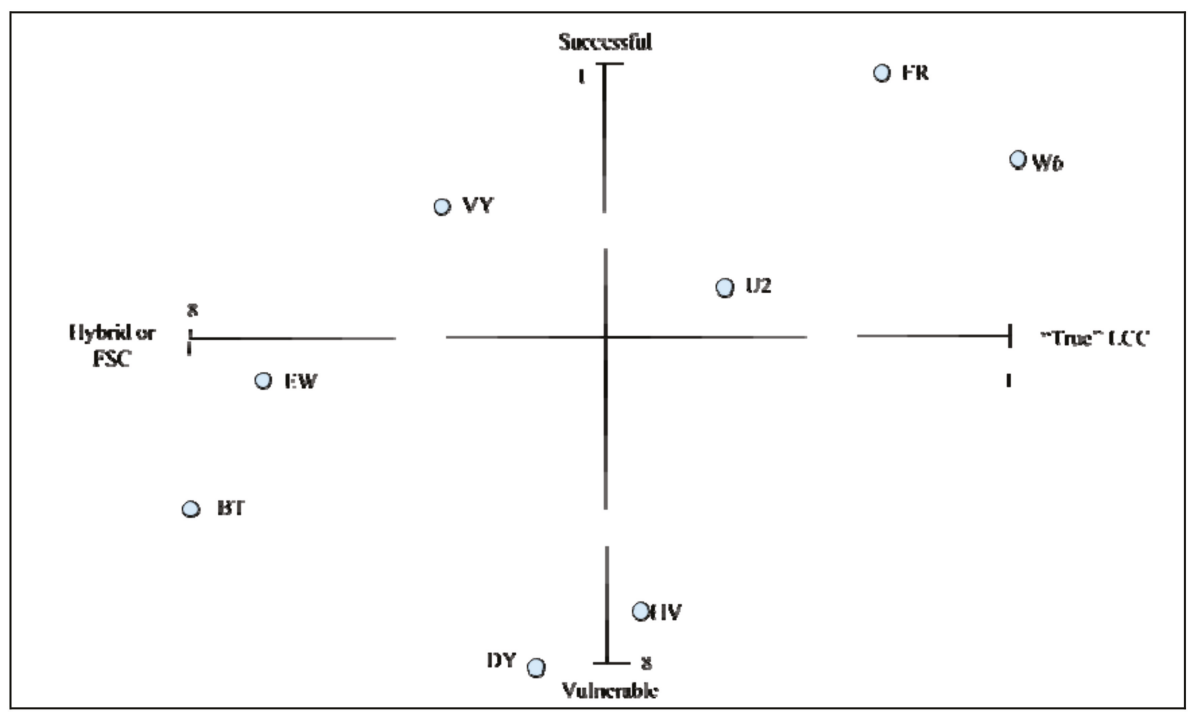

Figure 3. Quadrant diagram results of TOPSIS Source: compiled by the authors.

From the compiled quadrant diagram, it can be concluded that Ryanair and Wizz Air are the two airlines that are the most successful and meet the most LCC criteria. Also located in the "True LCC"-Successful quadrant, easyJet is the fourth most successful airline in this research. Based on this final result, it can be stated that the chances for a listed LCC to be successful are mainly based on how many criteria they meet to become a true LCC. Independence also seems to have an influence, as both Eurowings and Transavia are on the vulnerable side. Vueling is the only airline that is not meeting the majority of the LCC criteria and is a successful airline. Concerning the theory, it can be stated that airlines that are based on characteristics, which can be considered as "True LCC", are in the European market and are more likely to be successful than LCC airlines that are more focused on a hybrid model. The exact cost savings and profits have to take place in the case studies of the airlines. However, a single-type, young aircraft fleet seems to be more profitable than operating different aircraft types, as all the airlines that are on the "Successful" side have this in common. Additionally, high seat occupancy seems to be contributing to the success of the airline as well.

\section{Conclusions}

This research showed that the airline industry is growing quickly since 2010, as is described in the introduction, based on International Civil Aviation Organization (ICAO) (2018) in its annual report about 2017. Since the financial crisis of 2008 and 2009, the airline industry started growing and has nearly doubled in the number of passengers [83-86]. However, the airline industry has proven to be vulnerable to issues such as oil crises, financial crises, and the 9/11-terrorist attacks, and immediately showed a decline or a stop of growth. This research provided insight into the current development 
problems of the airline industry on its fastest-growing business model. It shows that an increase in oil prices is still one of the causes of serious airline troubles. However, airlines can counter this with a newer, more fuel-efficient fleet and successful fuel-hedging practices.

Issues of a whole other type are personnel problems, such as strikes. It is hard to find one exact reason for this issue. In the case of Ryanair, one of the airlines in this research, the reasons given by the pilots are a demand for a better salary, better rosters, and a base location closer to their homes. Furthermore, there are fleet problems, based on unexpected, required aircraft repairs and late deliveries of new aircraft. Airlines are forced to lease aircraft, which is a costly event. The last issue, airport capacity limitation, will affect every airline. Whether it is a limited runway capacity, aircraft stand capacity, or noise reduction measures. It will cause airports to run out of available slots for airlines. Given the high growth rate of the industry, the prices for a slot will go up. Airlines can counter this by flying to other airports (for example, secondary airports or by operating a modern, quieter aircraft).

As is visible from the conclusions given above, factors of LCCs can play a role in countering the negative effects of the development problems for airlines [11,12,87-95]. Flying to secondary airports of London, rather than the congested London Heathrow, operating a modern fleet, and achieving high load factors can counter effects. Machine problems, like engine problems such as Norwegian faced or late aircraft delivery (Primera Air), are difficult to prevent. It will delay the development of the airline and cause extra costs. Another risk is the stop of investments in an airline; this is, however, more risk for airlines that make a (structural) loss. Only Norwegian seems to have a riskier position on this issue.

The TOPSIS revealed as well that Wizz Air is the only airline meeting all the LCC criteria, whereas Ryanair and easyJet changed their business models during strategy changes. Wizz and Ryanair are both the most successful airlines of the group, with easyJet being in a third place. Subsidiary LCCs as Eurowings, Vueling, and Transavia are performing worse and are flying in general with the oldest fleet. Although ranking low on meeting LCC criteria, airBaltic is profitable and growing. It is implementing a brand new, efficient fleet and will shift to a single-type fleet. Norwegian is, given its loss and sale of new aircraft, ranking low.

Based on this research, in general, it can be concluded that the LCC business model has the potential for success regarding profitability and growth while having the possibility to counter the effects of some of the development problems in the industry. The efficient use of materials and a focus on a single type of aircraft can contribute to the success of the airline. Ryanair could counter its major effects of the personnel strikes, since its operating model led to successfulness, whereas Norwegian had to sell aircraft to maintain its existence. A further case study for each airline is recommended to for in depth research of how airlines survive the major issues in the airline industry. This research has led to the possible direction for research in the form of the exact operating model and risk prevention measures of the airlines. The case study of Vueling might give different insights, as it is a subsidiary airline, which is not meeting the majority of the LCC criteria, while it still is the third regarding successfulness within this research. It also has a rather small fleet on order and has one of the lowest seat occupancies amongst the airlines in this research. Further research can also be located in the operating models of FSCs and their success. Case studies can also lead to the improved weighting of the criteria for the MCDM analyses.

Author Contributions: Conceptualization, J.S. and G.F.V.K.; methodology, J.S.; software, G.F.V.K.; validation, J.S., G.F.V.K. and V.D.; formal analysis, V.D.; investigation, G.F.V.K.; resources, V.D.; data curation, J.S. writing-Original draft preparation, G.F.V.K.; writing-Review and editing, V.D.; visualization, V.D.; supervision, J.S.; project administration, V.D.; funding acquisition, V.D. All authors have read and agreed to the published version of the manuscript.

Funding: This research received no external funding.

Conflicts of Interest: The authors declare no conflict of interest. The funders had no role in the design of the study; in the collection, analyses, or interpretation of data; in the writing of the manuscript, or in the decision to publish the results. 


\section{Appendix A}

Table A1. Full calculations of the LCC criteria TOPSIS.

\begin{tabular}{cccccccccccc}
\hline Data & C1 & C2 & C3 & C4 & C5 & C6 & C7 & C8 & C9 & C10 & C11 \\
\hline Weight & 0.091 & 0.091 & 0.091 & 0.091 & 0.091 & 0.091 & 0.091 & 0.091 & 0.091 & 0.091 & 0.091 \\
Wizz Air & 1.000 & 1 & 1 & 1 & 1 & 1 & 1 & 1 & 1 & 1 & 1 \\
Ryanair & 0.994 & 1 & 1 & 1 & 1 & 1 & 1 & 1 & 1 & 1 & 0 \\
Transavia & 1.000 & 1 & 1 & 1 & 0 & 1 & 0 & 1 & 0 & 0 & 0 \\
easyjet & 0.997 & 1 & 1 & 1 & 0 & 1 & 1 & 1 & 1 & 1 & 0 \\
Vueling & 1.000 & 0 & 1 & 1 & 0 & 1 & 0 & 1 & 0 & 0 & 0 \\
airBaltic & 0.400 & 0 & 1 & 1 & 0 & 1 & 0 & 1 & 0 & 0 & 0 \\
Eurowings & 0.748 & 0 & 1 & 1 & 0 & 1 & 0 & 1 & 0 & 0 & 0 \\
Norwegian & 0.802 & 0 & 1 & 1 & 0 & 1 & 0 & 1 & 1 & 0 & 0 \\
\hline
\end{tabular}

Table A2. Full calculations of the LCC criteria TOPSIS.

\begin{tabular}{cccccccccccc}
\hline Normalized & C1 & C2 & C3 & C4 & C5 & C6 & C7 & C8 & C9 & C10 & C11 \\
\hline Wizz & 0.397 & 0.577 & 0.354 & 0.354 & 0.707 & 0.354 & 0.577 & 0.354 & 0.500 & 0.577 & 1.000 \\
Ryanair & 0.394 & 0.577 & 0.354 & 0.354 & 0.707 & 0.354 & 0.577 & 0.354 & 0.500 & 0.577 & 0.000 \\
Transavia & 0.397 & 0.577 & 0.354 & 0.354 & 0.000 & 0.354 & 0.000 & 0.354 & 0.000 & 0.000 & 0.000 \\
easyJet & 0.396 & 0.000 & 0.354 & 0.354 & 0.000 & 0.354 & 0.577 & 0.354 & 0.500 & 0.577 & 0.000 \\
Vueling & 0.397 & 0.000 & 0.354 & 0.354 & 0.000 & 0.354 & 0.000 & 0.354 & 0.000 & 0.000 & 0.000 \\
airBaltic & 0.159 & 0.000 & 0.354 & 0.354 & 0.000 & 0.354 & 0.000 & 0.354 & 0.000 & 0.000 & 0.000 \\
Eurowings & 0.297 & 0.000 & 0.354 & 0.354 & 0.000 & 0.354 & 0.000 & 0.354 & 0.000 & 0.000 & 0.000 \\
Norwegian & 0.319 & 0.000 & 0.354 & 0.354 & 0.000 & 0.354 & 0.000 & 0.354 & 0.500 & 0.000 & 0.000 \\
\hline
\end{tabular}

Table A3. Full calculations of the LCC criteria TOPSIS.

\begin{tabular}{cccccccccccc}
\hline Weighted & C1 & C2 & C3 & C4 & C5 & C6 & C7 & C8 & C9 & C10 & C11 \\
\hline Wizz & 0.036 & 0.052 & 0.032 & 0.032 & 0.064 & 0.032 & 0.052 & 0.032 & 0.045 & 0.052 & 0.091 \\
Ryanair & 0.036 & 0.052 & 0.032 & 0.032 & 0.064 & 0.032 & 0.052 & 0.032 & 0.045 & 0.052 & 0.000 \\
Transavia & 0.036 & 0.052 & 0.032 & 0.032 & 0.000 & 0.032 & 0.000 & 0.032 & 0.000 & 0.000 & 0.000 \\
easyJet & 0.036 & 0.000 & 0.032 & 0.032 & 0.000 & 0.032 & 0.052 & 0.032 & 0.045 & 0.052 & 0.000 \\
Vueling & 0.036 & 0.000 & 0.032 & 0.032 & 0.000 & 0.032 & 0.000 & 0.032 & 0.000 & 0.000 & 0.000 \\
airBaltic & 0.014 & 0.000 & 0.032 & 0.032 & 0.000 & 0.032 & 0.000 & 0.032 & 0.000 & 0.000 & 0.000 \\
Eurowings & 0.027 & 0.000 & 0.032 & 0.032 & 0.000 & 0.032 & 0.000 & 0.032 & 0.000 & 0.000 & 0.000 \\
Norwegian & 0.029 & 0.000 & 0.032 & 0.032 & 0.000 & 0.032 & 0.000 & 0.032 & 0.045 & 0.000 & 0.000 \\
\hline
\end{tabular}

Table A4. Full calculations of the LCC criteria TOPSIS.

\begin{tabular}{cccccccccccc}
\hline$V^{+}$(Best) & 0.036 & 0.052 & 0.032 & 0.032 & 0.064 & 0.032 & 0.052 & 0.032 & 0.045 & 0.052 & 0.091 \\
\hline$V^{-}$(Worst) & 0.014 & 0.000 & 0.032 & 0.032 & 0.000 & 0.032 & 0.000 & 0.032 & 0.000 & 0.000 & 0.000 \\
\hline
\end{tabular}

Table A5. Full calculations of the LCC criteria TOPSIS.

\begin{tabular}{ccccc}
\hline Airline & $\boldsymbol{S}_{\boldsymbol{i}}{ }^{+}$ & $\boldsymbol{S}_{\boldsymbol{i}}{ }^{-}$ & $\boldsymbol{P}_{\boldsymbol{i}}$ & Rank \\
\hline Wizz & 0 & 0.150025 & 1 & 1 \\
Ryanair & 0.091 & 0.119302 & 0.567533 & 2 \\
Transavia & 0.141 & 0.050349 & 0.262682 & 4 \\
easyJet & 0.123 & 0.100528 & 0.474484 & 3 \\
Vueling & 0.151 & 0.021655 & 0.127299 & 6 \\
airBaltic & 0.150 & 0 & 0 & 8 \\
Eurowings & 0.151 & 0.012572 & 0.077941 & 7 \\
Norwegian & 0.144 & 0.047719 & 0.252185 & 5 \\
\hline
\end{tabular}




\section{Appendix B}

Table A6. Full calculations of the successfulness TOPSIS.

\begin{tabular}{ccccccc}
\hline Data & C12 & C13 & C14 & C15 & C16 & C17 \\
\hline Weight & 0.1 & 0.05 & 0.15 & 0.4 & 0.1 & 0.2 \\
Wizz Air & 257 & 4.7 & 146 & 14.1 & 91.2 & 24 \\
Ryanair & 135 & 6.9 & 243 & 20 & 95.3 & 10.3 \\
Transavia & 0 & 8.2 & 115 & 5.6 & 90.6 & 11 \\
easyJet & 147 & 7.3 & 163 & 8.1 & 92.9 & 10.2 \\
Vueling & 45 & 7.2 & 112 & 12.7 & 84.7 & 6.5 \\
airBaltic & 36 & 9.4 & 70 & 5.8 & 76 & 22 \\
Eurowings & 4 & 11.1 & 137 & 2.3 & 79.9 & 77 \\
\hline
\end{tabular}

Table A7. Full calculations of the successfulness TOPSIS.

\begin{tabular}{ccccccc}
\hline Normalised & C12 & C13 & C14 & C15 & C16 & C17 \\
\hline Wizz & 0.752 & 0.217 & 0.345 & 0.463 & 0.369 & 0.277 \\
Ryanair & 0.395 & 0.319 & 0.569 & 0.656 & 0.385 & 0.119 \\
Transavia & 0.000 & 0.377 & 0.269 & 0.184 & 0.366 & 0.127 \\
easyJet & 0.366 & 0.337 & 0.382 & 0.266 & 0.375 & 0.118 \\
Vueling & 0.132 & 0.333 & 0.262 & 0.417 & 0.342 & 0.075 \\
airBaltic & 0.105 & 0.435 & 0.164 & 0.190 & 0.307 & 0.254 \\
Eurowings & 0.012 & 0.513 & 0.321 & 0.075 & 0.323 & 0.887 \\
Norwegian & 0.340 & 0.180 & 0.377 & -0.189 & 0.354 & 0.150 \\
\hline
\end{tabular}

Table A8. Full calculations of the successfulness TOPSIS.

\begin{tabular}{ccccccc}
\hline Weighted & $\mathbf{C 1 2}$ & $\mathbf{C 1 3}$ & $\mathbf{C 1 4}$ & $\mathbf{C 1 5}$ & $\mathbf{C 1 6}$ & $\mathbf{C 1 7}$ \\
\hline Wizz & 0.075 & 0.011 & 0.051 & 0.185 & 0.037 & 0.055 \\
Ryanair & 0.040 & 0.016 & 0.085 & 0.262 & 0.039 & 0.024 \\
Transavia & 0.000 & 0.019 & 0.040 & 0.073 & 0.037 & 0.025 \\
easyJet & 0.037 & 0.017 & 0.057 & 0.106 & 0.038 & 0.024 \\
Vueling & 0.013 & 0.017 & 0.039 & 0.167 & 0.034 & 0.015 \\
airBaltic & 0.011 & 0.022 & 0.025 & 0.076 & 0.031 & 0.051 \\
Eurowings & 0.001 & 0.026 & 0.048 & 0.030 & 0.032 & 0.177 \\
Norwegian & 0.034 & 0.009 & 0.057 & -0.075 & 0.035 & 0.030 \\
\hline
\end{tabular}

Table A9. Full calculations of the successfulness TOPSIS.

\begin{tabular}{ccccccc}
\hline$V^{+}$ & 0.085 & 0.009 & 0.075 & 0.262 & 0.039 & 0.177 \\
\hline$V^{-}$ & 0.025 & 0.026 & 0.000 & -0.075 & 0.031 & 0.015 \\
\hline
\end{tabular}

Table A10. Full calculations of the successfulness TOPSIS.

\begin{tabular}{cccc}
\hline $\mathbf{S}_{\mathbf{i}}{ }^{+}$ & $\mathbf{S}_{\mathbf{i}}{ }^{-}$ & $\mathbf{P}_{\mathbf{i}}$ & Rank \\
\hline 0.149 & 0.276 & 0.650 & 2 \\
0.158 & 0.346 & 0.687 & 1 \\
0.258 & 0.150 & 0.368 & 7 \\
0.225 & 0.189 & 0.457 & 4 \\
0.204 & 0.243 & 0.544 & 3 \\
0.243 & 0.156 & 0.391 & 6 \\
0.247 & 0.195 & 0.441 & 5 \\
0.372 & 0.052 & 0.122 & 8 \\
\hline
\end{tabular}




\section{References}

1. International Civil Aviation Organization. The World of Air Transport in 2017. Available online: https://www. icao.int/annual-report-2017/Pages/the-world-of-air-transport-in-2017.aspx (accessed on 5 December 2018).

2. International Civil Aviation Organization. Part 4-Regulatory content. In Manual on the Regulation of International Air Transport, 2nd ed.; Doc 9626; International Civil Aviation Organization: Montreal, QC, Canada, 2004.

3. International Civil Aviation Organization. Economic Development of Air Transport, Facts and Figures. Available online: https://www.icao.int/sustainability/Pages/Facts-Figures_WorldEconomyData.aspx (accessed on 21 November 2018).

4. Herremans, L. De Ontwikkeling van de Grote Low Cost Carriers in West-Europa Vanaf 2004: Een Economische Analyse; Vrije Universiteit Brussel: Brussels, Belgium, 2007. (In Dutch)

5. Vowles, T.M. The effect of low fare air carriers on airfares in the US. J. Transp. Geogr. 2000, 8, 121-128. [CrossRef]

6. Windle, R.; Dresner, M. Competitive responses to low cost carrier entry. Transp. Res. Part E Logist. Transp. Rev. 1999, 35, 59-75. [CrossRef]

7. Erkuş-Öztürk, H.; Terhorst, P. Variety of modes of governance of a global value. Tour. Geogr. 2010, 12, 217-245. [CrossRef]

8. Button, K. Low-cost airlines: A failed business model? Transp. J. 2012, 51, 197-219. [CrossRef]

9. Schlumberger, C.E.; Weisskopf, N. Ready for Takeoff? International Bank for Reconstruction and Development/The World Bank: Washington, DC, USA, 2014.

10. Dennis, N. End of the free lunch? The responses of tradional European airlines to the low-cost carrier threat. J. Air Transp. Manag. 2007, 13, 311-321. [CrossRef]

11. Klophaus, R.; Conrady, R.; Fichert, F. Low cost carriers going hybrid: Evidence from Europe. J. Air Transp. Manag. 2012, 23, 54-58. [CrossRef]

12. Doganis, R. Flying Off Course: Airline Economics and Marketing; Routledge: London, UK, 2009.

13. Miranda, M.; Baltazar, M.E.; Silva, J. Airlines performance and efficiency evaluation using a MCDA methodology. The case for low cost carriers vs legacy carriers. Open Eng. 2016, 6, 389-396. [CrossRef]

14. Ryanair. Annual Report FY 2018; Ryanair: Dublin, Ireland, 2018.

15. airBaltic. airBaltic Receives Tenth Airbus A220-300. Available online: https://www.airbaltic.com/en/airbalticreceives-tenth-airbus-a220-300 (accessed on 30 July 2018).

16. Ishikawa, K.; Loftus, J. Introduction to Quality Control; 3A Corporation: Tokyo, Japan, 1990.

17. Ryanair. Ryanair Cuts Fy19 Guidance by 12\% Due to Higher Oil Prices, Higher Eu261 Costs, \& Weaker Fares Due To Recent Strikes. Available online: https://corporate.ryanair.com/news/ryanair-cuts-fy19-guidanceby-12-due-to-higher-oil-prices-higher-eu261-costs-weaker-fares-due-to-recent-strikes/ (accessed on 1 October 2018).

18. BBC. Ryanair Pilots 'Reach Deal to end Strike'. BBC News, 23 August 2018. Available online: https: //www.bbc.com/news/world-europe-45280416 (accessed on 7 December 2018).

19. Tsang, A. Passengers are Stranded as Another European Airline Collapses. The New York Times. 2 October 2018. Available online: https://www.nytimes.com/2018/10/02/business/primera-air-collapse.html (accessed on 8 December 2018).

20. Slotnick, D. Primera Air, Which Sold $\$ 99$ Tickets from the US to Europe, is Filing for Bankruptcy and Shutting Down Operations. Business Insider. 1 October 2018. Available online: https://www.businessinsider.com/ primera-air-filing-for-bankruptcy-2018-10 (accessed on 8 December 2018).

21. The Associated Press. Air Berlin Files for Bankruptcy after Key Shareholder Pulls the Plug on Funding. CBC, 15 August 2018. Available online: https://www.cbc.ca/news/business/air-berlin-bankruptcy-protection-1. 4247874 (accessed on 9 December 2018).

22. Zuidberg, J.; Vinkx, K. Capacity Demand at Schiphol Airport in 2023; SEO Amsterdam Economics: Amsterdam, The Netherlands, 2018.

23. Benlic, U. Heuristic search for allocation of slots at network level. Transp. Res. Part C Emerg. Technol. 2018, 86, 488-509. [CrossRef] 
24. Cobbs, R.; Wolf, A. Jet Fuel Hedging Strategies: Options Available for Airlines and a Survey of Industrial Practices; Kellogg School of Management at Northwestern University: Evanston, IL, USA, 2004. Available online: http://www.kellogg.northwestern.edu/research/fimrc/papers/jetfuel.pdf (accessed on 9 December 2018).

25. Zuidberg, J. Identifying airline cost economies: An econometric analysis of the factors affecting aircraft operating costs. J. Air Transp. Manag. 2014, 40, 86-95. [CrossRef]

26. Mayor, K.; Tol, R.S. The impact of European climate change regulations on international tourist markets. Transp. Res. Part D Transp. Environ. 2010, 15, 26-36. [CrossRef]

27. Eurostat. Real GDP Growth Rate-Volume. Available online: https://ec.europa.eu/eurostat/tgm/table.do? tab=table\&init $=1 \&$ language $=$ en \&pcode $=$ tec00115\&plugin $=1$ (accessed on 10 December 2018).

28. International Air Transport Association (IATA). Economic Performance of the Airline Industry; International Air Transport Association: Montreal, QC, Canada, 2018.

29. Tzeng, G.H.; Huang, J.J. Multiple Attribute Decision Making: Methods and Applications; Chapman and Hall/CRC: Boca Raton, FL, USA, 2011.

30. Eurostat. Population on 1 January by Age Groups and Sex-Functional Urban Areas. 2016. Available online: http://appsso.eurostat.ec.europa.eu/nui/submitViewTableAction.do (accessed on 10 December 2018).

31. Deutsches Zentrum für Luft- und Raumfahrt. Low-Cost Monitor 2/2010; Deutsches Zentrum für Luft- und Raumfahrt: Cologne, Germany, 2010.

32. Flightradar24. Airlines. Available online: https://www.flightradar24.com/data/airlines (accessed on 30 November 2018).

33. Skyscanner. VNO-EIN. Available online: https://www.skyscanner.net/transport/flights/vno/ein/ 181213/?adults $=1 \&$ children $=0 \&$ adultsv $2=1 \&$ childrenv $2=\&$ infants $=0 \&$ cabinclass $=$ economy $\& r t n=0 \&$ preferdirects $=$ true\&outboundaltsenabled $=$ false\&inboundaltsenabled $=$ false $\&$ ref $=$ home\#details $/ 17567-$ 1812130715--31669-0-112 (accessed on 12 December 2018).

34. Skyscanner. VNO-AMM. Available online: https://www.skyscanner.net/transport/flights/vno/amm/ 181312/?adults $=1 \&$ children $=0 \&$ adultsv $2=1 \&$ childrenv2 $=\&$ infants $=0 \&$ cabinclass $=$ economy $\& r t n=0 \&$ preferdirects=false\&outboundaltsenabled $=$ false\&inboundaltsenabled $=$ false\&ref=home\#/ (accessed on 12 December 2018).

35. Skyscanner. EIN-KRK. Available online: https://www.skyscanner.net/transport/flights/ein/krk/ 181312/?adults $=1 \&$ children $=0 \&$ adultsv2 $=1 \&$ childrenv $2=\&$ infants $=0 \&$ cabinclass $=$ economy $\&$ rtn $=0 \&$ preferdirects=false\&outboundaltsenabled=false\&inboundaltsenabled=false\&ref=home\#/ (accessed on 12 December 2018).

36. Skyscanner. AMS-PRG. Available online: https://www.skyscanner.net/transport/flights/ams/prg/181213/ ?adultsv2=1\&childrenv2=\&cabinclass $=$ economy\&rtn=0\&preferdirects=true\&outboundaltsenabled $=$ false\&inboundaltsenabled=false\#details/9451-1812131845--32356-0-15538-1812132015 (accessed on 12 December 2018).

37. Skyscanner. MAD-BCN. Available online: https://www.skyscanner.net/transport/flights/mad/bcn/ 181312/?adults=1\&children $=0 \&$ adultsv2 $=1 \&$ childrenv2 $=$ \&infants $=0 \&$ cabinclass $=$ economy $\& r t n=0 \&$ preferdirects $=$ false\&outboundaltsenabled $=$ false\&inboundaltsenabled $=$ false $\&$ ref $=$ home\#/ $($ accessed on 12 December 2018).

38. Skyscanner. VNO-CDG. Available online: https:/www.skyscanner.net/transport/flights/vno/cdg/190907? flexible_origin=true\&flexible_depart=direct\&adults $=1 \&$ children $=0 \&$ adultsv $2=1 \&$ childrenv $2=\&$ infants $=$ $0 \&$ cabinclass $=$ economy \&rtn $=0 \&$ preferdirects $=$ true $\&$ outboundaltsenabled $=$ false \&inboundaltsenabled $=$ false\#det (accessed on 12 December 2018).

39. Skyscanner. DUS-TXL. Available online: https://www.skyscanner.net/transport/flights/duss/berl/ 190906/?adults $=1 \&$ children $=0 \&$ adultsv2 $=1 \&$ childrenv $2=\&$ infants $=0 \&$ cabinclass $=$ economy \&rtn $=0 \&$ preferdirects $=$ true \&outboundaltsenabled $=$ false \&inboundaltsenabled $=$ false $\&$ ref $=$ home\#details $/ 11165$ 1909060625--32332-0-1 (accessed on 12 December 2018).

40. Skyscanner. VNO-ARN. Available online: https://www.skyscanner.net/transport/flights/vno/arn/ 190909/?adults $=1 \&$ children $=0 \&$ adultsv $2=1 \&$ childrenv $2=\&$ infants $=0 \&$ cabinclass $=$ economy $\&$ rtn $=0 \&$ preferdirects=false\&outboundaltsenabled=false\&inboundaltsenabled=false\&ref=home\#/ (accessed on 12 December 2018).

41. airBaltic. Book a Flight. Available online: https://www.airbaltic.com/en-LT/index?opentab=FLT (accessed on 12 December 2018). 
42. Ryanair. Flights. Available online: https://www.ryanair.com/gb/en/ (accessed on 12 December 2018).

43. Wizz Air. Flights. Available online: https://wizzair.com/en-gb\#/ (accessed on 12 December 2018).

44. Vueling. Flights. Available online: https://www.vueling.com/en (accessed on 12 December 2018).

45. easyJet. Flight. Available online: https://www.easyjet.com/nl (accessed on 12 December 2018).

46. Norwegian Air Shuttle. Flight. Available online: https://www.norwegian.com/us/ (accessed on 12 December 2018).

47. Transavia. Homepage. Available online: https:/www.transavia.com/en-EU/home/ (accessed on 12 December 2018).

48. Eurowings. Flight Search. Available online: https://www.eurowings.com/skysales/Search.aspx?culture=enGB (accessed on 12 December 2018).

49. Ryanair. Always Getting Better. Available online: https://www.ryanair.com/gb/en/useful-info/about-ryanair/ always-getting-better (published 2018) (accessed on 10 December 2018).

50. easyJet. Worldwide by easyJet. Available online: https://www.easyjet.com/en/worldwide (published 2018) (accessed on 10 December 2018).

51. Flightradar24. Airports. Available online: https://www.flightradar24.com/data/airports (accessed on 30 November 2018).

52. Thomson, N.; Baden-Fuller, C. Basic Strategy in Context; John Wiley \& Sons: Hoboken, NJ, USA, 2010.

53. Czudar, E.; Ruwińska, K.; Ruck, N. The Customers' Perception of Wizz Air, the Largest Low_Fare Low-Cost Airline in Central Eastern Europe; University of Halmstad: Halmstad, Sweden, 2007.

54. Gutierrez, O. Review of Transavia Holland flight Amsterdam to Barcelona in Economy. Flight Report, 10 October 2015. Available online: https://flight-report.com/en/report/11916/Transavia_Holland_HV5133_ Amsterdam_AMS_Barcelona_BCN (accessed on 14 December 2018).

55. Loukas. Review of Air Baltic Flight Tallinn $\rightarrow$ Riga in Economy. Flight Report, 17 January 2016. Available online: https://flight-report.com/en/report/12983/Air_Baltic_BT_314_Tallinn_TLL_Riga_RIX (accessed on 14 December 2018).

56. RL 777. Review of Norwegian Flight Stockholm $\rightarrow$ Oslo in Economy. Flight Report, 12 August 2017. Available online: https:/flight-report.com/en/report/26490/Norwegian-DY807-Stockholm-ARN-Oslo-OSL (accessed on 8 December 2018).

57. Guillbcn. Review of Vueling Airlines Flight Stockholm $\rightarrow$ Barcelona in Economy. Flight Report. 8 February 2018. Available online: https://flight-report.com/en/report/32544/Vueling-Airlines-VY1266-Stockholm-ARNBarcelona-BCN (accessed on 14 December 2018).

58. Loukas. Review of Eurowings Flight Warsaw $\rightarrow$ Düsseldorf in Economy. Flight Report. 7 October 2017. Available online: https://flight-report.com/en/report/28171/Eurowings-EW-9725-Warsaw-WAW-D-sseldorfDUS (accessed on 14 December 2018).

59. Lufthansa Group. Annual Report 2017; Lufthansa Group: Frankfurt, Germany, 2018.

60. International Air Transport Association. Airline and Airport Code Search. Available online: https: //www.iata.org/publications/Pages/code-search.aspx (accessed on 5 December 2018).

61. Airfleets.net. Airline Fleet Ages. Available online: https://www.airfleets.net/ageflotte/fleet-age.htm (accessed on 30 November 2018).

62. Wizz Air. Destination Map. Available online: https://wizzair.com/en-gb/flights/map\#/ (accessed on 1 December 2018).

63. Transavia. Destinations. Available online: https://www.transavia.com/en-EU/destinations/ (accessed on 30 November 2018).

64. easyJet. Routemap. Available online: http://www.easyjet.com/en/routemap (accessed on 30 November 2018).

65. Eurowings. Destinations. Available online: https://www.eurowings.com/en/information/destinations.html (accessed on 30 November 2018).

66. Vueling. Destinations. Available online: https://www.vueling.com/en/we-are-vueling/destinations-andairports/destinations (accessed on 1 December 2018).

67. Norwegian Air Shuttle. Route Map. Available online: https://www.norwegian.com/us/route-map/ (accessed on 1 December 2018).

68. airBaltic. Destinations. Available online: https://www.airbaltic.com/en/destinations (accessed on 30 November 2018). 
69. airBaltic. airBaltic Reports Best Ever Operational Results in 2017. 2018. Available online: https://www. airbaltic.com/en/airbaltic-reports-best-ever-operational-results-in-2017 (accessed on 13 December 2018).

70. Wizz Air. Wizz Air Announces Order for 146 Airbus A320neo Aircraft. Wizz Air, 15 November 2017. Available online: https://wizzair.com/en-gb/information-and-services/about-us/news/2017/11/15/wizz-airannounces-order-for-146-airbus-a320neo-family-aircraft\#/ (accessed on 19 December 2018).

71. Norwegian Air Shuttle. Our Aircraft. Available online: https://www.norwegian.com/uk/about/our-story/ our-aircraft/ (accessed on 4 December 2018).

72. Skonnord, O.P. Corrected-Norwegian Air Sees Possible Airbus Aircraft Sales Before Year End. Reuters, 4 September 2018. Available online: https://www.reuters.com/article/norwegian-air-fleet/corrected-norwegian-air-seespossible-airbus-aircraft-sales-before-year-end-idUSL8N1VQ3J1 (accessed on 19 December 2018).

73. Kaminski-Morrow, D. IAG clears fleet expansion for recovering Vueling. Flightglobal, 31 July 2018. Available online: https://www.flightglobal.com/news/articles/iag-clears-fleet-expansion-for-recoveringvueling-439823/ (accessed on 19 December 2018).

74. Airbus. easyJet Orders Additional 17 A320neo. Available online: https://www.airbus.com/newsroom/pressreleases/en/2018/11/easyjet-orders-additional-17-a320neo.html (accessed on 20 November 2018).

75. Planespotters.net. Eurowings. Available online: https://www.planespotters.net/airline/Eurowings (accessed on 3 December 2018).

76. Ryanair. Ryanair Exercises 25 Boeing-Max-200 Options. 2018. Available online: https://corporate.ryanair. com/news/ryanair-exercises-25-boeing-max-200-options/ (accessed on 19 December 2018).

77. Ryanair. Destination List. Available online: https://www.ryanair.com/us/en/cheap-flight-destinations-list (accessed on 1 December 2018).

78. Norwegian Air Shuttle. Annual Report 2017; Norwegian Air Shuttle: Lysaker, Norway, 2018.

79. Wizz Air. Annual Report FY 2018; Wizz Air: Budapest, Hungary, 2018.

80. Air France-KLM. Full Year 2017 Results; Air France-KLM: Paris, France, 2018.

81. International Consilidated Airlines Group (IAG). Annual Report 2017; International Consolidated Airlines Group (IAG): London, UK, 2018.

82. easyJet. Annual Report FY 2017; easyJet: Luton, UK, 2017.

83. Mishenin, Y.; Koblianska, I.; Medvid, V.; Maistrenko, Y. Sustainable regional development policy formation: Role of industrial ecology and logistics. Enterp. Sustain. Issues 2018, 6, 329-341. [CrossRef]

84. Otter, C.; Watzl, C.; Schwarz, D.; Priess, P. Towards sustainable logistics: Study of alternative delivery facets. Entrep. Sustain. Issues 2017, 4, 460-476. [CrossRef]

85. Gerasimov, B.N.; Vasyaycheva, V.A.; Gerasimov, K.B. Identification of the factors of competitiveness of industrial company based on the module approach. Entrep. Sustain. Issues 2018, 6, 677-691. [CrossRef]

86. Batkovskiy, A.M.; Kalachikhin, P.A.; Semenova, E.G.; Telnov, Y.F.; Fomina, A.V.; Balashov, V.M. Conficuration of enterprise networks. Enterp. Sustain. Issues 2018, 6, 311-328. [CrossRef]

87. Korauš, A.; Mazák, M.; Dobrovič, J. Quantitative analysis of the competitiveness of Benelux countries. Entrep. Sustain. Issues 2018, 5, 1069-1083. [CrossRef]

88. Hilkevics, S.; Semakina, V. The classification and comparison of business ratios analysis methods. Insights Into Reg. Dev. 2019, 1, 47-56. [CrossRef]

89. Mahdiraji, H.; Govindan, K.; Zavadskas, E.; Hajiagha, S.H.R. Coalition or decentralization: A game-theoretic analysis of a three-echelon supply chain network. J. Bus. Econ. Manag. 2014, 15, 460-485. [CrossRef]

90. Lietuvnikè, M.M.; Vasilis Vasiliauskas, A.; Vasilienè-Vasiliauskienė, V.; Sabaitytè, J. Conceptual model for minimization of losses caused by illegal immigrants to road freight transport operators. Challenges to national defence in contemporary geopolitical situation. In Proceedings of the 1th International Scientific Conference: Challenges to National Defence in Contemporary Geopolitical Situation (CNDCGS-2018), Pabradè, Lithuania, 25-27 April 2018; pp. 167-173.

91. Singgalen, Y.A.; Sasongko, G.; Wiloso, P.G. Community participation in regional tourism development: A case study in North Halmahera Regency-Indonesia. Insights Into Reg. Dev. 2019, 1, 318-332. [CrossRef]

92. Zeibote, Z.; Volkova, T.; Todorov, K. The impact of globalization on regional development and competitiveness: Cases of selected regions. Insights Reg. Dev. 2019, 1, 33-47. [CrossRef]

93. Shevyakova, A.; Munsh, E.; Arystan, M. Information support for the development of tourism for the diversification of the economy of Kazakhstan. Insights Reg. Dev. 2019, 1, 138-154. [CrossRef] 
94. Chkalova, O.; Efremova, M.; Lezhnin, V.; Polukhina, A.; Sheresheva, M. Innovative mechanism for local tourism system management: A case study. Entrep. Sustain. Issues 2019, 6, 2052-2067. [CrossRef]

95. Yunus, E.; Susilo, D.; Riyadi, S.; Indrasari, M.; Putranto, T.D. The effectiveness marketing strategy for ride-sharing transportation: Intersecting social media, technology, and innovation. Entrep. Sustain. Issues 2019, 7, 1424-1434. [CrossRef]

(C) 2020 by the authors. Licensee MDPI, Basel, Switzerland. This article is an open access article distributed under the terms and conditions of the Creative Commons Attribution (CC BY) license (http://creativecommons.org/licenses/by/4.0/). 

Article

\title{
Energy Efficiency of Kazakhstan Enterprises: Unexpected Findings
}

\author{
Yelena Petrenko ${ }^{1, *}$, Igor Denisov ${ }^{1}$, Gaukhar Koshebayeva ${ }^{2}$ and Valeriy Biryukov ${ }^{2}$ \\ 1 Academic Department of Management Theory and Business Technologies, Plekhanov Russian University of \\ Economics, Moscow 117997, Russia; denisov.iv@rea.ru \\ 2 Faculty of Engineering Economics and Management, Karaganda State Technical University, \\ Karaganda 100027, Kazakhstan; gauhark@bk.ru (G.K.); valera@mail.ru (V.B.) \\ * Correspondence: petrenko.es@rea.ru; Tel.: +7-926-361-6170
}

Received: 18 January 2020; Accepted: 22 February 2020; Published: 27 February 2020

\begin{abstract}
The problems of efficient use of energy costs have been actively explored in recent decades in connection with rising energy prices. During this period, the main models for assessing energy efficiency and energy management were developed, including the models Total Quality Management, Six Sigma and Sustainable Value Stream Mapping. The aim of the research was to study the energy efficiency of the production and services in Kazakhstan based on materials of the large-scale national study on the estimation of production and transaction costs by these methodologies. To assess the data obtained, a statistical analysis of the dependence on the indicators of variation and ranking was used. Electricity costs are among the leading manufacturing costs and affect management models. However, according to the maturity model of energy management, energy efficiency in Kazakhstan is low. Despite the government's declarations of effective energy policies, the administrative burden for businesses remains high, and legislation does not stimulate a reduction in energy costs.
\end{abstract}

Keywords: costs; energy management; energy efficiency; Kazakhstan

\section{Introduction}

The problem of increasing energy efficiency is connected with the historical development of management systems. One of the purposes of industrial production management has always been to increase productivity. In periods when energy resources were cheap, electricity costs were an insignificant part of production costs and were an accounting item rather than an important management task [1]. Energy consumption was controlled by the accountant as part of overhead costs.

With rising energy prices, the share of energy costs in the value of the created product has increased significantly. It took a change in production processes to reduce these costs and energy management became part of the management system. This change was particularly evident in the development of European management in the last third of the 20th century [2]. During this period, an independent energy management area was formed, which is able to provide organizations with efficient use of production resources [3,4]. Having become part of the management system, energy management has been included in the solution of a wide range of environmental and social problems and has become an integral part of the organization's image $[5,6]$.

We aimed to study the energy efficiency of enterprises in Kazakhstan [7]. In Section 2, we look at issues of improving energy efficiency in industrial systems and the relationship of energy efficiency with creating value for the client. Section 3 is devoted to the research methodology and description of the source data. Section 4 contains an analysis of the results, which are discussed in Section 5. General conclusions are drawn and prospects for future research are determined in Section 6. 


\section{State of the Art}

\subsection{Increasing of Energy Efficiency of Industrial System}

Improving the energy efficiency of enterprises plays an important role at all management levels. At the national and regional levels, efficient use of energy helps to ensure a territory's energy independence and often ensures its political independence. The ability to create a product with fewer resources, including energy, allows organizations to increase customer satisfaction and increase their own competitiveness. Combining the interests of the state and business in improving energy efficiency has allowed the creation of a set of energy management tools.

Based on modern research, three categories of energy management tools were identified: compulsory, incentive, and educational.

- Let us include legal norms of legislative regulation of business entities into the compulsory measures. Their implementation is possible in countries with an established legal culture of population and business representatives, for example, in the countries of the European Union. In EU, such regulations are gradually evolving on the basis of national technical regulations (e.g., UNI-CEI-EN 16001: 2009), which are being transformed into supranational standards (EN 15900 and ISO 50001). At the international level, we can cite the example of the Kyoto Protocol (localized in Europe by Directive 2006/32/CE), which declares the need to clearly define goals, mechanisms, and incentives aimed at improving energy efficiency of national enterprises of the signatory states.

- Incentive events involve exposure to the manufacturer. In countries that actively use this method, financial incentive instruments as well as PR tools are used. It must be recognized that the domestic market of Kazakhstan is quite limited, which makes it less attractive for international companies with high labor productivity, protecting this way national producers. However, national producers need to increase labor productivity by improving the quality of the workforce. Kazakhstani workers and specialists still do not have the necessary competencies to generate internal resources for productivity growth and cost reduction.

- Educational methods imply an impact directly on the consumer, the formation of a new consumer culture based on careful environmental management, and a conscious choice of energy-saving technologies. In turn, consumer demand determines that supply-manufacturers-introduce "green" solutions to meet the wishes of customers.

Moreover, high complexity of sectoral energy systems becomes an objective barrier to energy efficiency growth in the industry. Production systems of industrial facilities with auxiliary components are not standardized and may differ significantly one from each other. This creates obstacles to creating generalized solutions and therefore does not allow for economies of scale. It also prevents and even leads to refusal of implementing potentially feasible energy-saving technologies [8]. The individual features of some energy-efficient technologies also prevent their implementation at industrial facilities [9].

Companies are constantly improving their production and management optimization processes. Industrial companies lack accessible and effective methods to address energy efficiency issues in production management. Six Sigma, Lean Manufacturing, and Total Quality Management are popular concepts used in many industries around the world, but each of them does not pay due attention to energy efficiency and environmental issues. Bunse et al. [3] suggested that future research should give preference to new control concepts, new visualization approaches, and evaluation methods in order to integrate energy efficiency into production management.

Thanks to the British government, companies use the "Matrix of Energy Management" [10], which makes it possible to understand and evaluate existing energy use patterns that track and measure future improvements and identify energy saving opportunities. The matrix is a five-level structure, which is analyzed on the basis of six main directions of energy management: energy policy, organization commitment, information systems, marketing, and investment. It enables companies to 
conduct self-assessments through analysis, identify areas for the development of energy management, and formulate measures for improvement not directly related to international standards.

Singh et al. [11] asserted that successful continuous improvement provides many opportunities to achieve the reduction of production cost while simultaneously growing client satisfaction. Ni et al. [12] found that continuous improvement positively influences organizational learning and leads to overall performance improvements. However, studies have found a time gap between continuous learning and improved efficiency. Jeyaraman et al. [13] in turn showed that staff responsibility, strong leadership, and access to relevant data are the main drivers of successful continuous improvement. Albliwi et al. [14] confirmed to a certain extent this conclusion by summarizing the factors of failure to create, maintain, and develop continuous improvements in enterprises, among which the main factors were the lack of committed management, insufficient communication, and insufficient training of operators.

The energy efficiency of the system can be increased through a holistic approach, where the study of individual components and functions is accompanied by the study of production systems and their external and internal customers. One of the possible strategies to find solutions that improve the effectiveness of the system is Value Stream Mapping (VSM). However, according to Faulkner et al. [15], the usual VSM methods do not count how energy contributes to value creation because they do not account for energy flows. Efficient energy management requires not only identification and use of a methodological approach, but also knowledge of energy efficiency methods and tools [16,17].

Svensson et al. [18] showed that modern VSM models underestimate the importance of the energy aspect, and there have been few studies and proposals for adding energy aspects to VSM [15]. Therefore, Alvandi et al. [19] argued that VSM does not take into account energy and resource consumption from a system-wide perspective, as it is limited to presenting the flow of a product family or individual product.

Modern companies realize that energy management is an effective tool for improving overall production efficiency, not just reducing energy costs. This approach is reflected in the provisions of ISO 50001, which describes the global energy management standards in force since its adoption in 2011.

The development of energy management required clarification of the applied concepts of "energy efficiency" and "energy conservation". Energy conservation is the process of reducing energy consumption through less consumption. It is a quantitative method of energy management aimed at reducing non-productive losses. Energy efficiency determines the quality of control by estimating the ratios of input resource to energy flow and result to energy consumption [20]. The task of energy management in this case is to obtain the maximum effect from each unit of energy consumed [21,22].

Over time, changes in the external environment have generated several economic and political factors that have changed the paradigm of managing energy costs. Multiple increases in energy prices were accompanied by increased public attention to environmental issues. As a result, the world community has moved towards the European Union's Greenhouse Gas Emissions Trading System (EU ETS) and the promotion of end-use optimization programs. To maintain their strategic competitive position, producers of industrial products with energy-intensive industries (oil and gas, metallurgical, etc.) had to move to a qualitatively new level of energy management.

In recent decades, significant progress has been made in the development of industrial energy management, but the overall level of energy efficiency remains inadequate. Researchers note that there is a significant potential for the introduction of already developed technologies to ensure high profitability of their implementation. However, a significant "energy efficiency gap" between the achievable and real levels has been formed [23]. Several studies focus on organizational "non-technical improvements", the implementation of which further increases the energy efficiency potential and widens the gap with the real level [24].

In the fight against global warming, the most important means is to improve energy efficiency in the industrial sector. In turn, industrial production thus increases the competitiveness of production and ensures sustainable development [25]. 
Even though energy management has proved to be effective in ensuring profitability, in real production practice, methods of direct restriction of energy consumption are still used rather than system control of its use in product creation. In general, industrial enterprises, having defined the limitations of direct saving methods, have moved to a more systematic approach to reducing losses, changing consumption principles and methods of energy flow management. Piper wrote thatm in "the past twenty years, energy management has repeatedly demonstrated itself as one of the most cost-effective ways to increase profitability" [26].

The problem of energy management as an independent and important part of the management system is especially topical for production enterprises, where $85 \%$ of the energy consumed is used to create a production processes [27]. The development of energy management was formed in the directions of evaluation of programs and practices of energy audit [28,29], development and evaluation of programs and measures for industrial end-use energy policies, benchmarking energy efficiency, and optimizing the power system or processes through statistical modeling [30].

Here are a few more definitions of energy management: "Energy management is considered as the proactive and systematic, coordination of procurement, conversion, distribution and use of energy within a company, aiming on continuously reducing energy consumption and related energy costs" [31]; "To us, energy management is: The efficient and effective use of energy to maximize profits (minimize costs) and enhance competitive positions" [32]; and "In our research we define "energy management in production' as including control, monitoring, and improvement activities for energy efficiency" [3].

Energy Management (EM) is the smart and efficient use of energy to maximize profit and strengthen competitive position. According to Petrecca [33], "energy management means ensuring that users receive all the necessary energy, when and where it is needed, as well as the required quality, delivered at the lowest cost". The separation of energy management into an independent management function has finally taken shape in the last two decades according to Capehart et al. [34]. Of course, this goal should be achieved while ensuring adequate safety for both production and environmental needs. Thus, the ultimate goal of energy management is the most efficient and effective use of energy supplied [26], which affects not only the supply and distribution of energy, but also its final usage. Energy management requires a systematic and ongoing approach, and it should not be confused with programs or projects that are time-limited, as noted by Piper [26].

\subsection{Connection of Energy Efficiency with Value Engineering for Customer}

Energy management is developed on the basis of integration of the general management theory, quality management concept, and other modern methodological approaches of economic theories $[35,36]$. In the application of energy management in production, the decisive role is played by the presence of a leader who consistently conducts the program of increasing the efficiency of energy use [37]. However, an administrative solution along will not ensure success; energy management programs provide for the participation of all members of the organization [38]. Large organizations consuming a significant amount of energy resources, as a rule, form special teams ensuring implementation of energy-saving programs [39]. Support of a leader from among top managers will ensure the efficiency of such team [40].

Modern management increases the value of a product by attracting consumers to create it at all stages of the value chain [41,42]. Different customer requests for consumer value generate different energy demand, which is not considered an important part of the process, since it does not generate revenue, but only reduces costs [43].

Traditional VSM models do not sufficiently take into account energy management capabilities, but Faulkner and Badurdeen included environmental factors and expanded the model to the Sustainable Value Stream Mapping (sus-VSM) format [15].

The sus-VSM model uses visual methods to evaluate the results of measuring energy consumption. Application of the model provides identification of the part of processes that consume significant 
energy resources, which allows further improvement of its use without compromising the creation of consumer value. However, modern sus-VSM still does not sufficiently take into account environmental and social factors and consumer needs. The lack of a clear methodology limits the widespread use of the model in various industries, since the inclusion of additional indicators in a number of production systems makes it more difficult to use visual maps. Faulkner and Badurdeen [15] recommended further studies using the sus-VSM method for various configurations of production systems to assess their suitability for use and identify problems in assembly and data analysis.

The development of energy management methods will increase the involvement of consumer requests in the processes of improving energy efficiency.

Historically, the formation of the existing structure of the electric power industry of the Republic of Kazakhstan and economic relations in it was determined by the goal of preserving the potential of the industry and its further development. In the period of transition of the economy to market relations, since 1995, the privatization of the main electric power facilities and the restructuring of the industry have been carried out. The reform of the electric power sector has led to a change in the form of public administration of the industry. Electricity transmission is carried out through the national electric network, by the state company "KEGOC" JSC. The national electric network consists of a set of substations, switchgears, and inter-regional and interstate power lines with a voltage of $\geq 35 \mathrm{kV}$. Electricity production in the country is carried out by 138 powerplants (including renewable energy facilities) of various forms of ownership, most being private. Electricity distribution in Kazakhstan is carried out by 18 regional energy companies (RECs) and about 150 small transmission companies that control regional-level electric networks with a voltage of $0.4-220 \mathrm{kV}$.

\section{Materials and Methods}

\subsection{Kazakhstan Energy Data}

The program of the Government of the Republic of Kazakhstan “Energy Conservation-2020" provided for a reduction in the energy intensity of the gross domestic product by at least $40 \%$ by 2020 from the 2008 level. However, no significant improvement was achieved, about 100 energy conversation projects were implemented annually, and the program was canceled [7]. In terms of energy intensity, Kazakhstan's Gross Domestic Product (GDP) is 119th of 143 countries.

Since 2012, Kazakhstan has passed a series of legislative acts defining the basic requirements in the field of energy efficiency. Currently, the law "On Energy Saving and Improving Energy Efficiency" is the main document. By 2020, the energy intensity of GDP should have decreased by $40 \%$, but the government's goal was not met. Given the conditions for the availability of cheap fuel and maintaining low tariffs for electricity and heat in Kazakhstan, energy conservation measures require significant investments and have relatively long payback periods. The main task of the state in achieving its goals to reduce the energy intensity of GDP is to create an effective legislative framework with the aim of stimulating energy efficiency in energy-intensive sectors of the economy. According to the data of Ministry of Energy of Republic of Kazakhstan, the annual increase in electricity consumption in the republic is about $5 \%$, while industry accounts for $58 \%$ of the consumption.

In 2017, a large-scale national study was conducted in Kazakhstan to assess production and transaction costs by the methodology Standard Cost Model (SCM), which was developed [44] to provide a simple and reliable method for assessing administrative costs incurred by government and individual departments to determine the magnitude of administrative barriers and measure the impact of reduction policies on them. SCM is designed to measure the administrative consequences of established regulation and requirements for enterprises. SCM does not aim to answer whether the barrier is justified-it gives an answer about how much it costs the business. The essence of SCM is to divide regulation into its constituent parts in the form of so-called "information" (that is, requiring the provision of information to authorities or other parties) obligations or requirements and administrative actions for their implementation. In addition, the time spent on individual operations 
are operationalized and evaluated. The total amount of time translated into money through labor and overhead costs gives the cost of the barrier from the standpoint of administrative costs.

The study examined the possibility of reducing the level of influence of state regulation om existing business relations with natural monopolies and the quasi-public sector. The tasks noted are an integral part of the energy management content, which allowed the authors to use the data of the primary research for secondary processing and analysis of the efficiency of energy costs at enterprises and organizations in Kazakhstan.

\subsection{Methods}

The methodology of this national study is presented in detail in an open publication [45]. The sample of research objects was 2,963 organizations, which provides a probability of $97 \%$ and a sampling error of $2 \%$ from the total population of 1,185,163 business entities. Sector quotas were carried out on the basis of GDP share, since costs are part of the final cost of the product.

As part of the study, a mass survey was conducted where 5,546 subjects were interviewed: owners, managers, and accountants. The sample corresponded to the planned probability level of $97 \%$. The survey form contained open and closed assessment questions on the Likert scale. Based on a mass survey, the impact of costs on energy supply for enterprises was assessed using the following rating scale: "costs did not change", "increased (up to 10\%)", "increased very (10-20\%)", "grew very much by $20-30 \%$ ", "critically increased from above 30\%", and "I find it difficult to answer" (Table 1).

Table 1. The share of organizations with a growth in production costs of more than $25 \%$.

\begin{tabular}{cccc}
\hline № & Costs & Manufacturing Sector & Services Sector \\
\hline 1 & Raw materials & 48 & 33 \\
2 & Salary of production workers & 31 & 23 \\
3 & Salary of auxiliary workers & 18 & 16 \\
4 & Depreciation & 37 & 20 \\
5 & Auxiliary materials & 22 & 14 \\
6 & Social package for workers & 15 & 11 \\
7 & Fuel & 50 & 27 \\
8 & Transportation & 38 & 22 \\
9 & Electricity & 39 & 35 \\
10 & Heating & 26 & 34 \\
\hline
\end{tabular}

Source: [7]

Electricity costs and transaction costs for energy supply monopolies are among the most significant for the economy of the republic. Kazakhstani managers point out that rising energy prices are a serious problem for business development. According to Kazakhstan managers, a significant problem for business development is primarily the rising prices for fuels and lubricants, energy, and raw materials. More than a third of respondents called energy supply costs a serious obstacle to current activities in industry and services. The scale of the answers allowed us to name the urgent problem of managing these costs and consider them as part of the broader problem of inefficient energy management.

The authors investigated the formation of energy management efficiency as control systems at various levels (see Figure 1). 


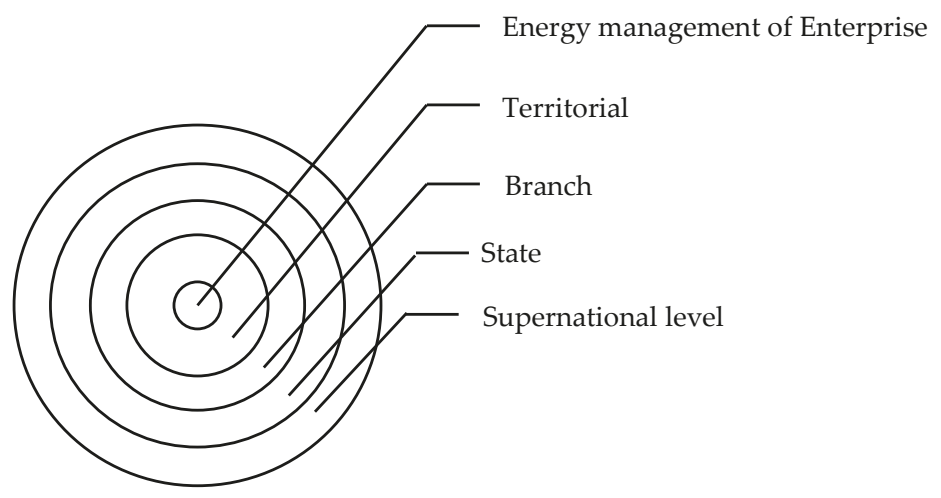

Figure 1. Schematic representation of energy management levels. Source: personal elaboration.

The level of energy costs was formed under the influence of factors of all levels. Each energy management level has a specific set of influence tools (Table 2).

Table 2. Energy Management Levels.

\begin{tabular}{cc}
\hline Levels & Factors and Instruments of Influence \\
\hline Supranational & Dominant and innovative technologies, global market conditions, international agreements \\
(quotas, norms, sanctions, etc.) \\
State & Laws, standards, tariffs, energy and environmental policies, social programs \\
Branch & The existing infrastructure, industry-specific management models, internal cooperation. \\
Territorial & Territorial infrastructure, resource availability, local statutory regulation \\
Enterprise & Production technology, control system \\
\hline & Source: personal elaboration.
\end{tabular}

Source: personal elaboration.

Energy management problems become more acute when assessing their effectiveness at various levels.

At present, the state manages the electric power industry through such levers as licensing, setting limit tariffs, regulating the activities of natural monopolies, etc. From the beginning of 2019 in Kazakhstan, along with the electric energy market, there is an electric power market. The tariff is divided into two components:

- The electricity tariff is a variable part that will provide a recoupment of costs for the production of electric energy.

- The capacity tariff is the permanent part, which will ensure the return on investment in the construction of new powerplants, while updating, modernizing, reconstructing, and expaning the existing ones.

However, the average levels of energy supply costs that have formed in various regions of the country show the heterogeneity of the implementation of state policy (Table 3). 
Table 3. The share of electricity costs in the total cost structure (\%).

\begin{tabular}{lcccccccc}
\hline Regions & $\begin{array}{c}\text { Akmola } \\
\text { region }\end{array}$ & $\begin{array}{c}\text { Aktubinsk } \\
\text { region }\end{array}$ & $\begin{array}{c}\text { Almata } \\
\text { region }\end{array}$ & $\begin{array}{c}\text { Atyrau } \\
\text { region }\end{array}$ & $\begin{array}{c}\text { West-Kazakhstan } \\
\text { region }\end{array}$ & $\begin{array}{c}\text { Zhambyl } \\
\text { region }\end{array}$ & $\begin{array}{c}\text { Karagnda } \\
\text { region }\end{array}$ & $\begin{array}{c}\text { Kostanay } \\
\text { region }\end{array}$ \\
\hline Portion & 5.7 & 6.5 & 5.6 & 9.7 & 7.5 & 2.5 & 10.1 & 7.7 \\
\hline Regions & $\begin{array}{c}\text { Kyzylorda } \\
\text { region }\end{array}$ & $\begin{array}{c}\text { Mangistau } \\
\text { region }\end{array}$ & $\begin{array}{c}\text { South- } \\
\text { Kazakhstan } \\
\text { region }\end{array}$ & $\begin{array}{c}\text { Pavlodar } \\
\text { region }\end{array}$ & $\begin{array}{c}\text { North- } \\
\text { Kazakhstan } \\
\text { region }\end{array}$ & $\begin{array}{c}\text { East- } \\
\text { Kazakhstan } \\
\text { region }\end{array}$ & $\begin{array}{c}\text { Astana } \\
\text { city }\end{array}$ & $\begin{array}{c}\text { Almaty } \\
\text { city }\end{array}$ \\
\hline Portion & 9.1 & 8.7 & 8.0 & 15.9 & 4.6 & 5.7 & 5.1 & 2.8 \\
\hline
\end{tabular}

The spread of electricity costs is significant across the republic. The average value of the indicator for manufacturing enterprises is $7.2 \%$, with a range of variation of $13.4 \%(R=X \max -X \min =15.9-$ $2.5=13.4)$. In the most energy-intensive industrial region of Pavlodar region, where energy-intensive metallurgical production is located, the average cost of electricity is $15.9 \%$ of the cost structure. The lowest indicator $-2.5 \%$ falls on the Zhambyl region with low volumes of industrial production.

Graphical analysis involves checking the normal distribution, which would be characteristic for the implementation of a unified energy management policy in the republic (see Figure 2).

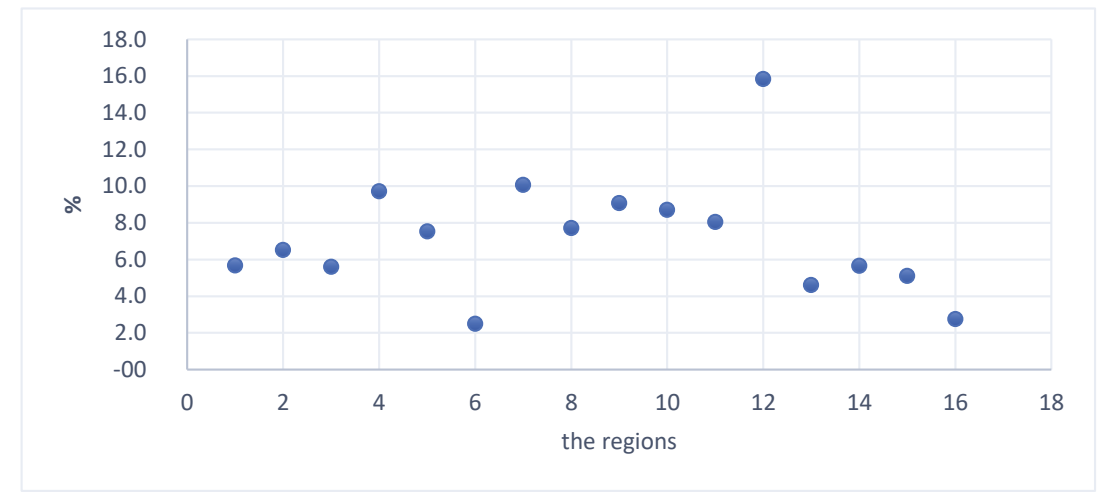

Figure 2. Distribution of the average share of energy costs across the republic (\%). Source: personal elaboration.

To assess the degree of difference in the territorial significance of energy costs, standard indicators of variation were calculated.

Coefficient of variation-as a measure of the relative spread of the values of the population—shows the ratio of the standard deviation to the mean.

$$
v=\frac{\sigma}{\bar{x}}=\frac{3.136}{7.2} 100 \%=43.56 \%,
$$

Each value of the series differs from the average value of $7.2 \%$ by an average of $3.136 \%$. Since the coefficient of variation is within $30 \%<\mathrm{v}<70 \%$, the variation is moderate. The presence of moderate variation may indicate the presence of a single (state) policy in the field of energy supply management. However, such national energy management is not efficient enough, which creates an asymmetry of indicators. The degree of asymmetry determines the moment coefficient of asymmetry.

$$
\text { As }=\mathrm{M}_{3} / \mathrm{S}^{3} \text {, }
$$

where M3 is the central moment of the third order, $\mathrm{S}$ is the standard deviation. 


$$
\begin{gathered}
\mathrm{M}_{3}=482.38 / 16=30.15, \\
\mathrm{~A}_{\mathrm{s}}=30.15 / 3.1363=0.977
\end{gathered}
$$

A positive value indicates a right-handed asymmetry. The right-sided asymmetry of the values of the share of energy costs indicates a shift in costs towards their increase, which may arise due to insufficient efficiency of state energy management, which increases costs due to an increase in the administrative burden. In the future, this assumption should be checked, including the possibility of corruption.

The industry level of energy management was considered separately for production and services. The industry-wide assessment of the level of influence of energy costs in production is presented in Table 4.

As noted above, electricity costs are in the top 10 costs of industrial enterprises. The share of the item "electricity" in the total cost structure of manufacturing enterprises also has a spread from $6.2 \%$ to $10.5 \%$ in the processing of agricultural products. However, graphical analysis suggests the proximity to the normal distribution and the relationship between cost increases and the assessment of the strength of influence on the management model (Figure 3).

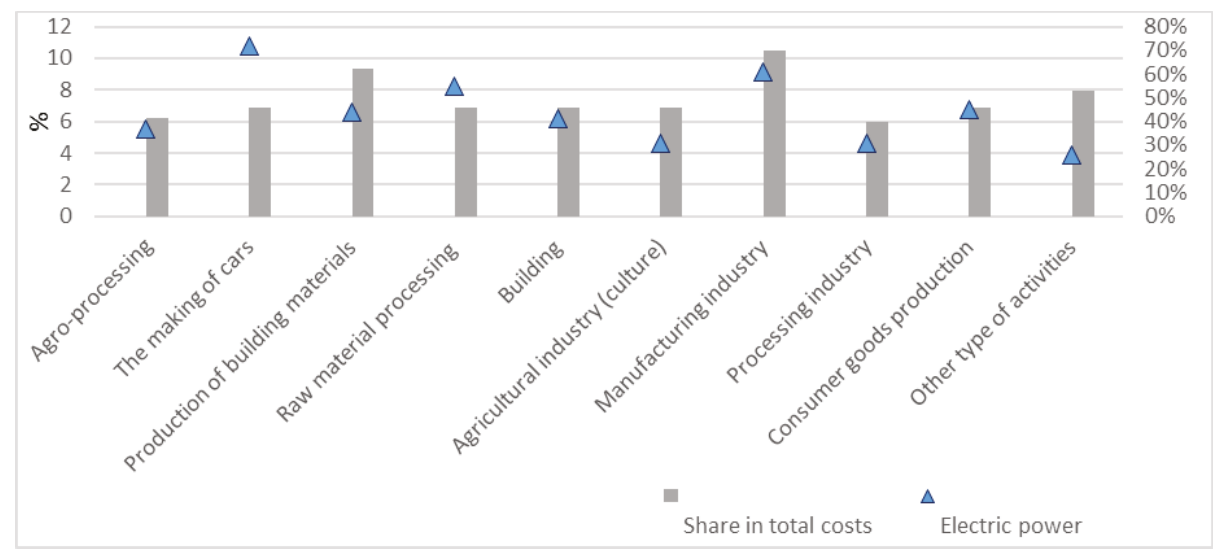

Figure 3. Effect of energy costs in production.

Note that the impact of the cost item was assessed according to the responses of managers who indicated that the cost of electricity at their enterprise increased by more than $25 \%$ and had a significant impact on the production process. Respondents' answers are a subjective assessment but reflect the effectiveness of production management models that can regulate the overall cost structure and production efficiency. 
Energies 2020, 13, 1055

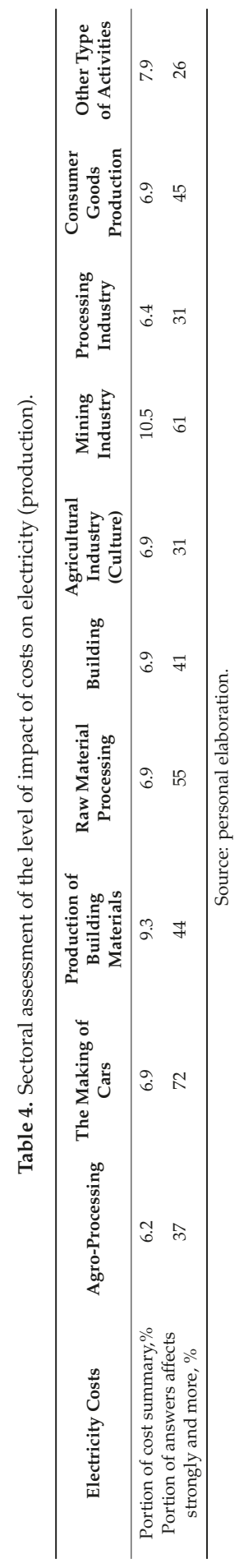


The relationship between the opinions of managers and the share of costs was checked using Spearman's rank correlation coefficient.

Since among the values of the signs $\mathrm{x}$ and $\mathrm{y}$ there are several identical ones, i.e., related ranks are formed, in this case, the Spearman coefficient is calculated as:

$$
\mathrm{p}=1-\frac{\sum 6 \mathrm{~d}^{2}+\mathrm{A}+\mathrm{B}}{\mathrm{n}^{3}-\mathrm{n}}
$$

where

$$
\begin{aligned}
& \mathrm{A}=\frac{1}{12} \sum\left(\mathrm{A}_{\mathrm{j}}^{3}-\mathrm{A}_{\mathrm{j}}\right) \\
& \mathrm{B}=\frac{1}{12} \sum\left(\mathrm{B}_{\mathrm{k}}^{3}-\mathrm{B}_{\mathrm{k}}\right)
\end{aligned}
$$

$\mathrm{j}$ is the number of ligaments for characteristic $X$.

$A_{j}$ is the number of identical ranks in the $j$ th connective along $X$.

$\mathrm{k}$ is the number of ligaments for characteristic $\mathrm{Y}$.

$\mathrm{B}_{\mathrm{k}}$ is the number of identical ranks in the kth bunch according to $\mathrm{U}$.

$$
\begin{gathered}
\mathrm{A}=[(53-5)] / 12=10 \\
\mathrm{~B}=[(23-2)] / 12=0.5 \\
\mathrm{D}=\mathrm{A}+\mathrm{B}=10+0.5=10.5 \\
\mathrm{p}=1-\frac{6 \times 112.5+10.5}{10^{3}-10}=0.308
\end{gathered}
$$

The calculation shows that the connection between the attribute $Y$ and factor $X$ is weak and direct.

The presence of a direct, but weak connection shows that, in production, an increase in electricity costs and an increase in their share in the total cost structure leads to the need to change production management models. However, the specifics of production are such that, in the value chain, energy is an input resource and is involved in the process of creating a product at the initial stage. The increase in the cost of electricity in production falls on the total costs and in the future the negative impact is smoothed out either by increasing the price or by adjusting the costs at the subsequent stages of the chain.

\section{Results}

Processing interviews with Kazakhstani managers shows that they do not consider energy saving at the production stage as a priority task of developing production and increasing its efficiency. The model of Kazakhstan's energy management at the enterprise level can be assessed as passive.

An assessment of the level of impact of electricity costs in the services sector is presented in Table 5 and differs significantly from the situation in production.

The authors believe that in the service sector a fundamentally different role is played for electricity costs in the value chain. Due to the specifics of the service (it is impossible to save, separate from the consumer, etc.), electricity consumption is necessary at almost all stages of the chain. Different types of services require a different share of energy costs and fundamentally different energy management models are implemented. Graphical analysis also shows differences and contradictions in assessing the strength of the impact of rising energy costs in various types of services (Figure 4). 
Energies 2020, 13, 1055

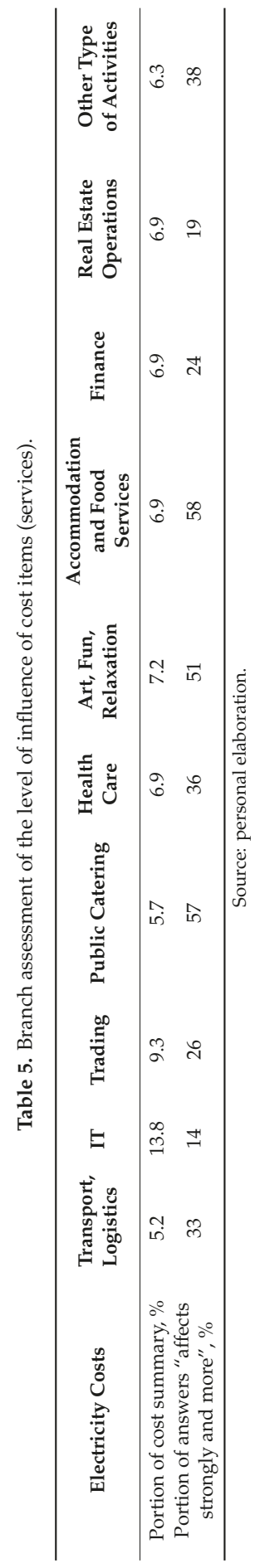




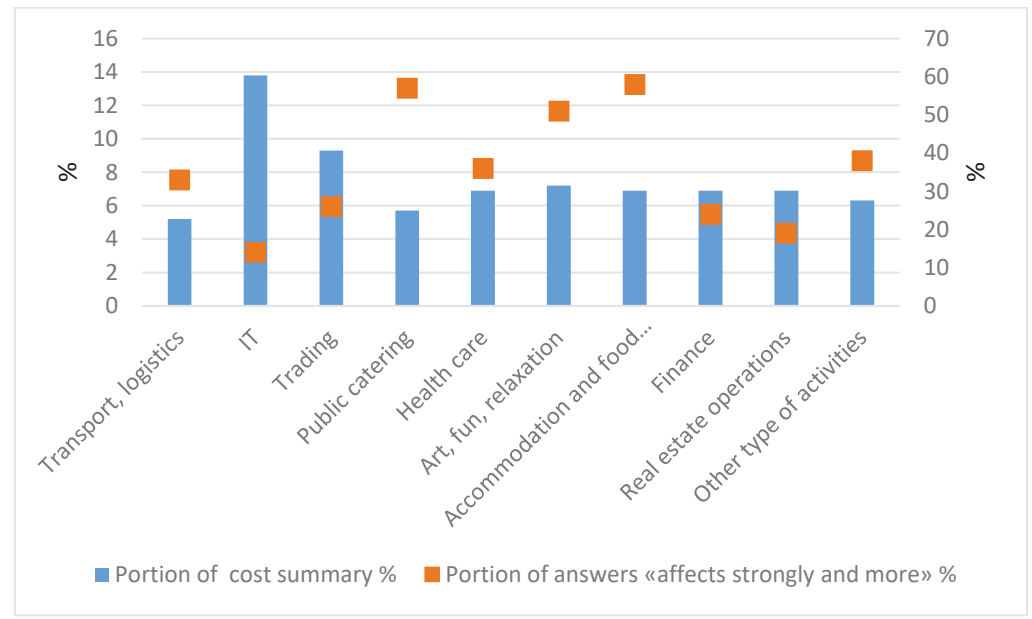

Figure 4. The impact of energy costs in the service sector. Source: personal elaboration.

The relationship was also checked according to the Spearman rank correlation criterion (see Table 6).

Table 6. Ranking by Y and factor X.

\begin{tabular}{cccc}
\hline $\begin{array}{c}\mathbf{X} \\
\begin{array}{c}\text { Portion of Cost } \\
\text { Summary, \% }\end{array}\end{array}$ & $\begin{array}{c}\mathbf{Y} \\
\text { Portion of Answers “Affects } \\
\text { Strongly and More", } \%\end{array}$ & $\begin{array}{c}\text { Rank } \mathbf{~} \\
\mathbf{d}_{\mathbf{x}}\end{array}$ & $\begin{array}{c}\text { Rank } \mathbf{~} \\
\mathbf{d}_{\mathbf{y}}\end{array}$ \\
\hline 5.19 & 33 & 1 & 5 \\
13.78 & 14 & 10 & 1 \\
9.3 & 26 & 9 & 4 \\
5.67 & 57 & 2 & 9 \\
6.94 & 36 & 4 & 6 \\
7.2 & 51 & 8 & 8 \\
6.94 & 58 & 4 & 10 \\
6.94 & 24 & 4 & 3 \\
6.94 & 19 & 4 & 2 \\
6.33 & 38 & 3 & 7 \\
\hline
\end{tabular}

Source: personal elaboration.

Since among the values of the signs $x$ and $y$ there are several identical ones, i.e., related ranks are formed, in this case, the Spearman coefficient is calculated as:

$$
\begin{gathered}
\mathrm{A}=[(43-4)] / 12=5 \\
\mathrm{D}=\mathrm{A}+\mathrm{B}=5 \\
p=1-\frac{6 \times 226+5}{10^{3}-10}=-0.375
\end{gathered}
$$

Calculations showed that the relationship between trait $\mathrm{Y}$ and factor $\mathrm{X}$ is weak and inverse. In a number of types of services, an increase in the share of electricity costs does not lead to a strong influence on the overall business efficiency. IT services have the largest share of energy costs in the overall cost structure, but their management is such that they are less concerned about the growth of these costs. At the same time, public catering has a rank of 2 in terms of costs, but in assessing the 
impact a rank of 9. In this type of service, energy supply is involved at all stages of the value chain from cooking to creating conditions for consumption.. The cost of electricity in this type of service is not so high in terms of the share of total costs, but catering management is energy-sensitive. A similar situation exists in the field of accommodation services.

In general, the energy management of Kazakhstan's business services sector is more heterogeneous than in production. Non-volatile control models and energy-sensitive models are used, where electricity takes part in the chains of creating the material and emotional value of the service. Such industries (food, accommodation, and recreation) have not yet developed an effective energy management model.

Energy management at the enterprise level is formed not only under the influence of industry or territorial factors, but is also largely determined by the dimension of the business. During the study, an assessment was received of 83 microbusiness entrepreneurs, 817 small businesses, 348 medium-sized enterprises, and 100 large business companies. Electricity costs have a steady tendency to decline in proportion as the enterprise grows. The share of electricity costs in large business is three times less than at the initial stage of development, i.e., in microbusiness (Figure 5).

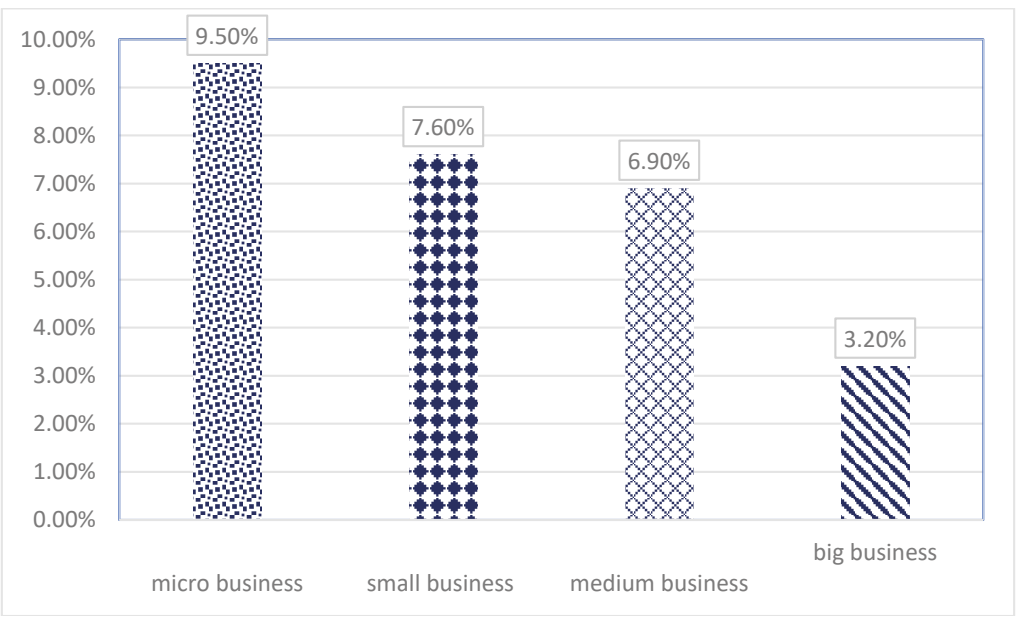

Figure 5. The portion of electricity costs for a business of various sizes. Source: personal elaboration.

\section{Discussion}

As the study showed, for small businesses, the cost of electricity is more significant, because enterprises do not have efficient energy management models. Large enterprises build their own energy management models taking into account international experience and global influence factors. The state provides for the requirements to introduce energy management systems in enterprises consuming more than 1050 tonnes of oil equivalent per year, while ISO 50001 was chosen as the main energy management standard, for which the corresponding state standard was adopted and approved.

Small-and medium-sized enterprises need help in mastering energy-saving models. According to the estimates of Kazakhstan Institute for the Development of Electric Power and Energy Saving (JSC), on average, enterprises can reduce energy consumption by $10 \%$ by budget organizations and small businesses up to $40 \%$.

In addition to direct production costs, enterprises in Kazakhstan bear the additional administrative burden of providing electricity. In the Doing Business-2019 rating, Kazakhstan took 67th place [46] in terms of connection to the energy supply system. Every fourth entrepreneur noted the strong impact of cost costs in obtaining permits from the state (monopolists and the quasi-public sector) and in the process of state control. Our studies show that, in addition to the costs directly related to the payment 
of energy consumption services, business entities have to bear serious financial costs for obtaining additional services of monopolistic enterprises.

In the course of a survey of specialists from companies conducting financial and/or accounting, the following types of additional services of natural monopolies holder (NMH) in the energy sector were found and analyzed:

- connection (disconnection) of electrical installations to electrical networks of energy-transmitting organizations;

- connection to heat networks of an energy transmission (energy producing) organization;

- connection of electrical installations to electric networks of energy-transmitting organizations of $\mathrm{NMH}$ according to the requirements reflected in the technical conditions of $\mathrm{NMH}$;

- connection of heat consumption systems to heat networks of a power transmission (energy producing) organization according to the requirements of technical conditions for connecting heat energy consumers issued by NMH;

- obtaining permits from NMH when carrying out work related to changing the electricity metering scheme;

- payment of the costs of extraordinary verification of a commercial meter for electric energy for connection (if the consumer is disconnected for violation of the terms of the power supply agreement);

- payment of the costs of extraordinary verification of a commercial water meter and connection (if the consumer is disconnected for violation of the terms of the contract);

- payment of costs for the extraordinary verification of a commercial meter for thermal energy and for connection (if the consumer is disconnected for violation of the terms of the heat supply agreement); and

- costs associated with obtaining information about the availability of free capacities of natural monopolies (information costs for electricity, heat, and water).

The administrative burden for energy is not only an extensive list, but also a large variation in prices for similar services. The authors carried out a secondary grouping of the cost of services for connecting to the elements of the electric grid infrastructure (Figure 6).

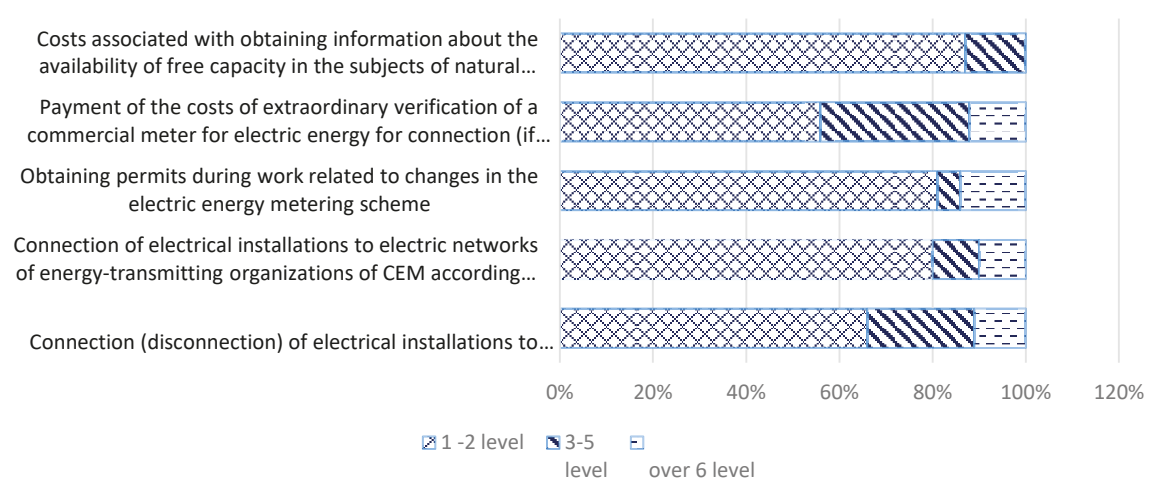

Figure 6. Cost of services for connecting to elements of the power grid infrastructure. Source: personal elaboration.

Data on the cost of services were brought to six conditional levels. The first level at the time of the assessment was 20 thousand tenge (equivalent to 64 dollars at the rate in April 2017). The third level is from $300 \%$ to $500 \%$ of the first level, while the sixth level includes costs exceeding the initial level by 
six times or more. According to the article "Obtaining permits from NMH when carrying out work related to changing the electricity metering scheme" for $10 \%$ of entrepreneurs, marginal costs were 35 times higher than the services that $80 \%$ of enterprises received at the base cost.

We did not set a special goal to investigate the problem of corruption, but Petrenko et al. [45] indicated the significant role of corruption in the economy of Kazakhstan. A special role in this context is given to the energy sector, in which corruption can reach $75 \%$. To a large extent, for this reason, a significant gap in the cost of similar services across territories and entities is noted not only by the low level of energy management, but also contains a corruption component. The study identified the costs of enterprises associated with corruption costs (Table 7).

Table 7. Corruption costs.

\begin{tabular}{ccc}
\hline Transactional Corruption Costs & \multicolumn{2}{c}{ Answers "Affects Strnogly". \% } \\
\cline { 2 - 3 } & Production & Services \\
\hline Bribery to the officer of state & $13 \%$ & $16 \%$ \\
Bribery to the bank representative of the second level & $10 \%$ & $13 \%$ \\
Bribery to the representative of natural monopoly holder (NMH) & $10 \%$ & $9 \%$ \\
\hline
\end{tabular}

Source: personal elaboration.

The costs incurred by enterprises under the article "Obtaining permits from NMH when carrying out work related to changing the electricity metering scheme" averaged 277.5 thousand tenge (890 dollars) according to the calculations for the year; 446.5 thousand entities used the service and incurred cumulative costs of 123.9 billion tenge (397 million dollars). According to experts, this service should be completely canceled. Connection (disconnection) of electrical installations to electric networks of energy-transmitting organizations on average in the republic costs 183.3 thousand tenge (588 dollars); it was proposed to reduce it by $50 \%$, which would lead to a reduction in costs of 41 billion tenge (131 million dollars).

According to the maturity model of energy management [47], the matrix indicators-"Awareness, knowledge, and skills", "Methodological approach", "Energy characteristics of leadership", "Organizational structure", and "Strategy and alignment" — at the first level are described by the values "fragmented" and "does not exist." The second level of the energy matrix of maturity is characterized by "Appointment of a person responsible for energy" and "Definition of policy and public information campaign".

According to the results of the study, it is obvious that Kazakhstan companies can be considered as being at the first (Initial) or, for larger organizations, possibly at the second (Occasional) level (see Table 8).

The government of Kazakhstan also sets mutually exclusive tasks in the current period: frontal reduction of costs while replenishing the budget. It is obvious that for state executive bodies the need to replenish the budget will always be a priority and therefore motivates the fiscal authorities to impose finesand other penalties in every possible case, which places an additional burden, especially on small- and medium-sized businesses. "The Energy Conservation-2020" program, which sets ambitious goals and whose adoption in 2013 was widely reported in the media, was relatively quietly canceled already in 2016, which may indicate both the lack of development of the program itself and its objective inefficiency.

In these conditions, to increase the energy efficiency of national companies, there is a need to review the regulatory framework and enforce the abolition of all unsustainable penalties that impede business development, since they are not only a financial burden, but also a psychological barrier. 
Table 8. Levels and dimensions of maturity in EMMM.

\begin{tabular}{|c|c|c|c|c|c|}
\hline \multirow[t]{2}{*}{ Level } & \multicolumn{5}{|c|}{ Maturity Measurement } \\
\hline & $\begin{array}{l}\text { Awarness, } \\
\text { knowledge, } \\
\text { skills }\end{array}$ & $\begin{array}{l}\text { Methodological } \\
\text { approach }\end{array}$ & $\begin{array}{c}\text { Energy } \\
\text { characteristics of } \\
\text { leadership }\end{array}$ & $\begin{array}{l}\text { Organizational } \\
\text { structure }\end{array}$ & $\begin{array}{c}\text { Strategy and } \\
\text { alignment }\end{array}$ \\
\hline 5 & Optimized & Optimized and used & Optimized and used & Optimized and used & Optimized and used \\
\hline 4 & High-technology & $\begin{array}{l}\text { Energy management } \\
\text { system used }\end{array}$ & $\begin{array}{l}\text { Improved, Stable } \\
\text { and Used }\end{array}$ & $\begin{array}{l}\text { Improved, Stable } \\
\text { and Used }\end{array}$ & all justification \\
\hline 3 & $\begin{array}{l}\text { considerable } \\
\text { progress }\end{array}$ & $\begin{array}{c}\text { project-based } \\
\text { approach in usage }\end{array}$ & $\begin{array}{c}\text { Standardised and } \\
\text { used }\end{array}$ & project organization & $\begin{array}{c}\text { Considerable } \\
\text { progress (general } \\
\text { progress) }\end{array}$ \\
\hline 2 & Basic & $\begin{array}{l}\text { Random } \\
\text { Identification } \\
\text { Intervention }\end{array}$ & Basic & $\begin{array}{l}\text { Appointment of a } \\
\text { responsible person } \\
\text { for the energy sector }\end{array}$ & $\begin{array}{l}\text { Policymaking and } \\
\text { Public Information } \\
\text { Campaign }\end{array}$ \\
\hline 1 & Segmental & It does not exist & It does not exist & $\begin{array}{c}\text { Scattered } \\
\text { (nonexistent) }\end{array}$ & It does not exist \\
\hline
\end{tabular}

Thus, the conclusions obtained in this article suggest a further study of the resulting phenomenon, which is characterized by:

1. Small business interest in developing energy management and improving corporate energy efficiency.

2. The declarative interest of the state and a small movement in the real implementation of the model of energy management systems (ISO 50001: 2011), which is a guide for organizations. Additionality in the world division of labor, world trade and, therefore, global competition suggests the possibility of further research on obtaining non-trivial conclusions for national enterprises.

\section{Conclusions}

The national economy of Kazakhstan is characterized by high energy intensity. The main gross product is created in the sectors of mining, oil and gas production, and metallurgy. Labor productivity in industry remains low, and the state protects domestic producers by various measures. It must be recognized that the domestic market of Kazakhstan is quite limited, which makes it less attractive for international companies with high labor productivity, thus protecting national producers. However, national producers need to increase labor productivity by improving the quality of the workforce. Kazakhstani workers and specialists still do not have the necessary competencies that can generate internal resources for productivity growth and cost reduction. Therefore, rational management practices are needed to maintain long-term energy efficiency gains. The GDP of Kazakhstan is produced with unreasonably high energy costs. There are significant and clear opportunities to reduce energy consumption in industry, transport, and utilities. In this context, Kazakhstani business lacks the necessary level of productivity to compete internationally. Therefore, any increase in costs not absorbed by productivity growth puts enterprises at risk and, when significant, has a negative impact on the national economy. In turn, the task of productivity growth lies in the plane of technological restructuring of production. As long as production uses obsolete tangible assets, productivity will be low and costs excessive. Kazakhstani industry needs renovation of fixed assets and the government should stimulate introduction of modern energy-saving equipment.

The materials in this article expand the analysis of previously conducted studies that determined that research on production costs should be conducted separately by industry [45]. A significant part of production energy costs is unproductive. Sale of energy on the Kazakhstan market is carried out on a monopoly basis by quasi-public suppliers on an overestimated tariff [48].

The Government of Kazakhstan in the current period sets mutually exclusive tasks: frontal cost reduction and budget replenishment. The need to replenish the budget motivates fiscal authorities to 
impose fines, and other penalties in every possible case, and this places an additional burden, especially on small- and medium-sized businesses. It is necessary to revise the regulatory framework and abolish all irrational penalties that impede the development of a business at such a critical time, being not only a financial burden, but also a psychological barrier.

Author Contributions: Methodology, Y.P. and I.D.; Project administration, Y.P.; Resources, Y.P.; Supervision, Y.P.; Validation, Y.P.; Writing—original draft, Y.P., G.K. and V.B. All authors have read and agreed to the published version of the manuscript.

Funding: This research received no external funding.

Conflicts of Interest: The authors declare there is no conflict of interest.

\section{References}

1. Caffal, C. Energy Management in Industry; Centre for the Analysis and Dissemination of Demonstrated Energy Technologies (CADDET): Sittard, The Netherlands, 1995; Analyses series Volume 17.

2. Dobes, V. New Tool for Promotion of Energy Management and Cleaner Production on No Cure, No Pay Basis. J. Clean. Prod. 2013, 39, 255-264. [CrossRef]

3. Bunse, K.; Vodicka, M.; Schönsleben, P.; Brülhart, M.; Ernst, F.O. Integrating Energy Efficiency Performance in Production Management-Gap Analysis between Industrial Needs and Scientific Literature. J. Clean. Prod. 2011, 19, 667-679. [CrossRef]

4. Strielkowski, W.; Lisin, E.; Astachova, E. Economic Sustainability of Energy Systems and Prices in the EU. Entrep. Sustain. Issues 2017, 4, 591-600. [CrossRef]

5. Amundsen, A. Joint Management of Energy and Environment. J. Clean. Prod. 2000, 8, 483-494. [CrossRef]

6. Dudin, M.N.; Frolova, E.E.; Protopopova, O.V.; Mamedov, O.; Odintsov, S.V. Study of Innovative Technologies in the Energy Industry: Nontraditional and Renewable Energy Sources. Entrep. Sustain. Issues 2019, 6, 1704-1713. [CrossRef]

7. Petrenko, E.; Pizikov, S.; Mukaliev, N.; Mukazhan, A. Impact of Production and Transaction Costs on Companies' Performance According Assessments of Experts. Entrep. Sustain. Issues 2018, 6, 398-410. [CrossRef]

8. Brunke, J.-C.; Johansson, M.; Thollander, P. Empirical Investigation of Barriers and Drivers to the Adoption of Energy Conservation Measures, Energy Management Practices and Energy Services in the Swedish Iron and Steel Industry. J. Clean. Prod. 2014, 84, 509-525. [CrossRef]

9. Fleiter, T.; Hirzel, S.; Worrell, E. The Characteristics of Energy-Efficiency Measures-A Neglected Dimension. Energy Policy 2012, 51, 502-513. [CrossRef]

10. Carbon Trust. Energy Management-A Comprehensive Guide to Controlling Energy Use; The Carbon Trust: London, UK, 2013.

11. Singh, J.; Singh, H. Continuous Improvement Approach: State-of-Art Review and Future Implications. Int. J. Lean Six Sigma 2012, 3, 88-111. [CrossRef]

12. Ni, W.; Sun, H. The Relationship among Organisational Learning, Continuous Improvement and Performance Improvement: An Evolutionary Perspective. Total Qual. Manag. Bus. Excell. 2009, 20, 1041-1054. [CrossRef]

13. Jeyaraman, K.; Teo, L.K. A Conceptual Framework for Critical Success Factors of Lean Six Sigma: Implementation on the Performance of Electronic Manufacturing Service Industry. Int. J. Lean Six Sigma 2010, 1, 191-215. [CrossRef]

14. Albliwi, S.; Antony, J.; Lim, S.A.H.; van der Wiele, T. Critical Failure Factors of Lean Six Sigma: A Systematic Literature Review. Int. J. Qual. Reliab. Manag. 2014, 31, 1012-1030. [CrossRef]

15. Faulkner, W.; Badurdeen, F. Sustainable Value Stream Mapping (Sus-VSM): Methodology to Visualize and Assess Manufacturing Sustainability Performance. J. Clean. Prod. 2014, 85, 8-18. [CrossRef]

16. Morvay, Z.K.; Gvozdenac, D.D. Fundamentals for Analysis and Calculation of Energy and Environmental Performance. In Applied Industrial Energy and Environmental Management; John Wiley \& Sons, Ltd.: Hoboken, NJ, USA, 2008.

17. Capobianchi, S.; Andreassi, L.; Introna, V.; Martini, F.; Ubertini, S. Methodology Development for a Comprehensive and Cost-Effective Energy Management in Industrial Plants. Energy Manag. Syst. 2011. [CrossRef] 
18. Svensson, A.; Paramonova, S. An Analytical Model for Identifying and Addressing Energy Efficiency Improvement Opportunities in Industrial Production Systems-Model Development and Testing Experiences from Sweden. J. Clean. Prod. 2017, 142, 2407-2422. [CrossRef]

19. Alvandi, S.; Li, W.; Schönemann, M.; Kara, S.; Herrmann, C. Economic and Environmental Value Stream Map (E2VSM) Simulation for Multi-Product Manufacturing Systems. Int. J. Sustain. Eng. 2016, 9, 354-362. [CrossRef]

20. Herring, H. Is Energy Efficiency Good for the Environment? Some Conflicts and Confusion. In The UK Energy Experience: A Model or a Warning; Mackerron, G., Pearson, P., Eds.; Imperial College Press: London, UK, 1996; pp. 327-338.

21. Sarma, U.; Karnitis, G.; Zuters, J.; Karnitis, E. District Heating Networks: Enhancement of the Efficiency. Insights Reg. Dev. 2019, 1, 200-213. [CrossRef]

22. Iysaouy, L.E.; Idrissi, N.E.A.E.; Tvaronavičienè, M.; Lahbabi, M.; Oumnad, A. Towards Energy Efficiency: Case of Morocco. Insights Reg. Dev. 2019, 1, 259-271. [CrossRef]

23. Hirst, E.; Brown, M. Closing the Efficiency Gap: Barriers to the Efficient Use of Energy. Resour. Conserv. Recycl. 1990, 3, 267-281. [CrossRef]

24. Backlund, S.; Thollander, P.; Palm, J.; Ottosson, M. Extending the Energy Efficiency Gap. Energy Policy 2012, 51, 392-396. [CrossRef]

25. Laitner, J.A.; McDonnell, M.T.; Keller, H.M. Shifting Demand: From the Economic Imperative of Energy Efficiency to Business Models that Engage and Empower Consumers. Energy Effic. 2013, 445-470. [CrossRef]

26. Piper, J.E. Operations and Maintenance Manual for Energy Management; Sharpe Professional: Armonk, NY, USA, $1999 ;$ p. 368.

27. Klugman, S.; Karlsson, M.; Moshfegh, B. A Scandinavian Chemical Wood Pulp Mill. Part 1. Energy Audit Aiming at Efficiency Measures. Appl. Energy 2007, 84, 326-339. [CrossRef]

28. Shen, B.; Price, L.; Lu, H. Energy Audit Practices in China: National and Local Experiences and Issues. Energy Policy 2012, 46, 346-358. [CrossRef]

29. Fleiter, T.; Gruber, E.; Eichhammer, W.; Worrell, E. The German Energy Audit Program for Firms-a Cost-Effective Way to Improve Energy Efficiency? Energy Effic. 2012, 5, 447-469. [CrossRef]

30. Giacone, E.; Mancò, S. Energy Efficiency Measurement in Industrial Processes. Energy 2012, 38, 331-345. [CrossRef]

31. German Energy Agency. Handbook for Corporate Energy Management_Systematically Reducing Energy Costs; German Energy Agency: Berlin, Germany, 2010.

32. Capehart, B.L.; Turner, W.C.; Kennedy, W.J. Guide to Energy Management: International Version; The Fairmont Press: Lilburn, GA, USA, 2008.

33. Petrecca, G. Industrial Energy Management: Principles and Applications. In Industrial Energy Management: Principles and Applications XXXIII; Springer Science+Business Media: New York, NY, USA, 1993; p. 430.

34. Capehart, B.L.; Turner, W.C.; Kennedy, W.J. Guide to Energy Management; CRC Press: Boca Raton, FL, USA, 2005.

35. Park Dahlgaard, S.M. The Human Dimension in TQM-Learning, Training and Motivation; Lund University Publications: Lund, Sweden, 2002.

36. Soltani, E.; Lai, P.-C.; Javadeen, S.R.S.; Gholipour, T.H. A Review of the Theory and Practice of Managing TQM: An Integrative Framework. Total Qual. Manag. Bus. Excell. 2008, 19, 461-479. [CrossRef]

37. Yukl, G. Leadership in Organizations; Pearson Education Limited: Edinburg, England, 2013; p. 528.

38. The ENERGY STAR Guidelines for Energy Management. Available online: https://www.energystar.gov/ buildings/reference/guidelines (accessed on 15 January 2020).

39. Lackner, P.; Holanek, N. Step by Step Guidance for the Implementation of Energy Management. In BESS Project Handbook; Austrian Energy Agency: Vienna, Austria, 2007; p. 84.

40. Vesma, V. Energy Management Principles and Practice-A Companion to BS en 16001:2009; Hive House Publishing: Manchester, UK, 2017; p. 178.

41. Conti, T. Quality Thinking and Systems Thinking. TQM Mag. 2006, 18, 297-308. [CrossRef]

42. Cronemyr, P.; Danielsson, M. Process Management 1-2-3-A Maturity Model and Diagnostics Tool. Total Qual. Manag. Bus. Excell. 2013, 24, 933-944. [CrossRef]

43. Cooremans, C. Investment in Energy Efficiency: Do the Characteristics of Investments Matter? Energy Effic. 2012, 5, 497-518. [CrossRef] 
44. International Standard Cost Model Manual-OECD.org. Available online: http://www.oecd.org/gov/ regulatory-policy/34227698.pdf (accessed on 15 January 2020).

45. Petrenko, E.; Iskakov, N.; Metsyk, O.; Khassanova, T. Ecosystem of Entrepreneurship: Risks Related to Loss of Trust in Stability of Economic Environment in Kazakhstan. Entrep. Sustain. Issues 2017, 5, 105-115. [CrossRef]

46. Doing Business. 2019. Available online: https://www.doingbusiness.org/en/reports/global-reports/doingbusiness-2019 (accessed on 15 January 2020).

47. Introna, V. Comparative Analysis of Maturity Models. In Project Management Maturity (Maturità Nella Gestione Progetti); PMI: Newtown Square, PA, USA, 2009; pp. 163-173.

48. Official Site. President of the Republic of Kazakhstan. Available online: http://www.akorda.kz/en/addresses/ addresses_of_president/state-of-the-nation-address-by-the-president-of-the-republic-of-kazakhstannursultan-nazarbayev-january-10--2018 (accessed on 16 January 2020).

(C) 2020 by the authors. Licensee MDPI, Basel, Switzerland. This article is an open access article distributed under the terms and conditions of the Creative Commons Attribution (CC BY) license (http://creativecommons.org/licenses/by/4.0/). 


\title{
Renewable Energy in Final Energy Consumption and Income in the EU-28 Countries
}

\author{
Mihaela Simionescu ${ }^{1, *}$, Wadim Strielkowski ${ }^{2}$ and Manuela Tvaronavičiené $\dot{e}^{3,4}$ \\ 1 Faculty of Management, University of Social Sciences, 9 Sienkiewicza St., 90-113 Łódź, Poland \\ 2 Department of Trade and Finance, Faculty of Economics and Management, Czech University of Life Sciences \\ Prague, Kamýcká 129, 16500 Prague, Czech Republic; strielkowski@pef.czu.cz \\ 3 Department of Business Technologies and Entrepreneurship, Vilnius Gediminas Technical University, \\ Sauletekio 11, 10223 Vilnius, Lithuania; manuela.tvaronaviciene@vgtu.lt \\ 4 General Jonas Zemaitis Military Academy of Lithuania, Silo 5A, 10322 Vilnius, Lithuania \\ * Correspondence: mihaela.simionescu@ipe.ro
}

Received: 26 March 2020; Accepted: 24 April 2020; Published: 5 May 2020

\begin{abstract}
The deployment of renewable energy sources (RES) is considered to be an important objective for the energy sector in the European Union (EU). The EU Directive adapted in 2009 fixed mandatory national targets for the use of renewable energy in transport as well as for the share of RES in the gross final energy consumption. Contrary to previous studies, this paper does not examine the link between the RES and economic growth but rather focuses on real gross domestic product (GDP) and the implementation of national renewable energy targets. We employ panel data models for the case of the EU-28 countries covering the period between 2007 and 2017 that yield a low and positive relationship between the impact of GDP per capita and the share of RES in the final consumption. Our results show that there is a significant causality only from real GDP per capita to the share of renewable energy in final consumption, marking the potential of developed countries to consume more RES. We list some groups of countries according to these variables using a cluster analysis approach. Starting from the proposed panel data models, we constructed the scenarios for the 2020 for various shares of RES and different EU Member States. Overall, it appears that more attention should be attributed to policy proposals in which funding opportunities would be dependent on the achievements of national targets and economic benefits should be given to countries with very good performance in achieving high shares of renewable energy in their final energy consumption.
\end{abstract}

Keywords: renewable energy sources; energy consumption; GDP per capita; European Union

\section{Introduction}

One important global concern nowadays is related to the adverse effects of the climate change and to the belief that it should be stopped. One of the solutions for this impending problem is the reduction of the emissions of greenhouse gases (GHG) that could be made by replacing the fossil fuels with renewable energy sources (RES) [1]. There are infinite sources of energy on Earth represented by the sun, wind, stream, and sea that could protect the environment and reduce the emissions of GHG. Moreover, prior to the Industrial Revolution, all energy was obtained from renewable sources, which supports the hypothesis that energy is an important input factor for production. However, due to the growing demand for energy in the 21st century, better technology should be used to exploit RES and provide energy at a lower price.

The EU emissions trading system (EU ETS) is an important tool for reducing the level of GHGs and it represents an important part of the EU's policy for managing climate change. This system is applied in the EU countries, including United Kingdom, but also in Norway, Liechtenstein, and Iceland. It established limits for the emissions from airlines between these countries and from more than 
11,000 installations that intensively use energy. Some targets were proposed for 2020 and for 2030. The target for 2020 will be surpassed (emissions in the targeted sectors are by $21 \%$ lower than the level in 2005), while the target for 2030 was raised to $43 \%$ compared to 2005 . The EU ETS rules were revised in 2018 to allow power sector and industry to implement innovation and make investments for low-carbon transition. Moreover, free allocation of allowances continued to ensure competitiveness and to reflect technological progress. The Market Stability Reserve was reinforced and the pace of annual reduction in allowances was fixed at 2.2\% starting from 2021.

The concern about a sustainable future and the use of RES is also prevalent in the European Union (EU). Here, renewable energy could be obtained from various sources with each country having a dominant source. For example, one could find wind turbines in Germany, hydro power plants in Austria, nuclear power plants in France, biomass in the Netherlands, wind power in Denmark and in the North Sea [2]. In general, there are two types of renewable energy sources in existence:

- $\quad$ Traditional RES (e.g., hydro energy, or biomass);

- $\quad$ New renewable sources (solar, wind, geothermal energy, etc.) [3]

The energetic potential of the European Union and the consumption of renewable energy considerably affect its economy and, consequently, the standard of living for all its citizens. In addition, the energy strategy developed by the EU focuses on more directions that should be analyzed in the frame of sustainable development:

- $\quad$ securing the energy supply and costs;

- $\quad$ ensuring that energy costs do make Europe less energy dependent;

- $\quad$ protecting the environment and mitigating climate change;

- $\quad$ improving energy networks [4].

RES should be analyzed from a macroeconomic point of view, given the fact that sustainable development is a goal of the EU. In this context, all sectors of the economy should converge to an evolution that supports the pillars of sustainable development (economic development, social development, and environmental protection). At a macroeconomic level, one should focus on the relationship between output and aspects related to RESs that might support economic growth which constitutes a goal for any given economy. Therefore, our research question is related to the role of RESs in supporting economic development. GDP per capita is considered a good proxy for the economic development that also determines the standard of living in any given country. Within this context, the main objective of our paper is to study the share of renewable energy consumption in relation to the GDP per capita in the EU in the period 2007-2017 using a panel data approach that can also capture the differences between the countries in an overall framework.

Apart from the connection between RES and the economy, RES could be linked to the environmental challenges. An important issue is related to RES volatility. This issue is determined by the nature of the RES technologysince RES can only produce electricity when the wind is blowing and the sun is shining. According to Sinn, the best strategy to buffer the RES volatility supposes demand management, pumped storage, and structures that retain traditional plants and grid expansions [5]. Pumped storage plants ensure a better energy management. Big storage needs are required by the volatility of power consumption. Nuclear power plants and lignite plants might also be used to address volatility.

An important advantage of the renewable energy is related to the reduction of harmful emissions. This type of energy has the capacity to decrease the greenhouse gas (GHG) emissions. However, a more stable legal framework and supportive financing conditions should be ensured [6].

A European Directive adapted in 2009 prescribes the implementation of the National Action Plans for renewable energy (National Renewable Energy Action Plans-NREAPs) that was submitted by all the EU Member States to the European Commission (EC) [7]. The Directive provides details about the policy of regional planning, facilitating and equal access to electricity, nature and environment protection, requiring a fast adaptation to the new energy sources. Each EU country established own 
targets to introduce legislation for achieving the required goals. All EU Member States must customize the existing regulations of established goals [8].

The European Central Bank (ECB) supports investment in renewable energy projects, while commercial banks finance mature technologies that present less risk (e.g., wind farms). The EU funds are also allocated to the research and development of the new technologies and test of the energy potential of these technologies, innovation in technological processes, smart grids, and pilot plants [9].

Article 194 of the EU Treaty makes RES development and promotion the key objectives for the EU energy sector. Moreover, Directive 2009/28/EC fixes mandatory national targets for the RES shares in transport and in the gross final energy consumption [10]. These mandatory national targets correspond with the EU's objective of reaching the $20 \%$ of RES in the gross final energy consumption by 2020 and at least $10 \%$ of transport fuel production covered by the renewable sources.

The development and promotion of energy savings and energy efficiency should be achieved in cooperation with the EU Member States and third countries (Directive 2009/28/EC). A progress report with information on the promotion and utilization of RES should be delivered by each EU country once every two years [11]. By 2030, the share of RES in the gross final energy consumption should increase to a minimum of $27 \%$ as the 2030 Climate and Energy Policy Framework stated. In the Energy Union strategy, renewable energies contribute to the decarbonisation of the energy system. The EU Cohesion Policy (2014-2020) makes investments of EUR 29 billion in sustainable energy which include renewable energy, energy efficiency, smart energy infrastructure and innovation as well as the research into low-carbon future [12].

In general, the renewables share in the gross final energy consumption is perceived to be one of the main indicators of the Europe 2020 target. It indicates the degree of the utilization of renewable energy and the extent to which fossil and/or nuclear fuels were substituted by RES on the way to the EU decarbonisation. Several EU Member States already reached this target before 2020 while the others are aiming at achieving it by 2020 [13].

The final energy consumption in the EU Member States relies upon such factors as economic development, structure of energy system, and the availability of RES. Eurostat [14] defines energy consumption in a number of ways at the national levels.

The gross final energy consumption is defined as the energy used by the end consumers plus the self-consumption of power plants and grid losses. The Renewable Energy Directive (2009/28/EC) estimates the gross final energy consumption as a sum of energy commodities intended for energy purposes and aimed at the final consumers (transport, services, industry, households, agriculture, and fisheries and forestry), consumption of heat and electricity by the heat and electricity production sectors, as well as losses of heat and electricity during the distribution and transmission [15].

Gross inland consumption represents the amount of energy required for covering the inland consumption of a given region. Gross inland consumption consists of primary product receipts, indigenous production, direct use from imports, stock changes. However, exports and international marine bunkers are not included. Gross inland energy consumption describes the overall energy demand of a region or a country. It represents the volume of energy for satisfying inland consumption of the analysed region. Gross inland energy consumption includes the final energy consumption by the end users, consumption by the energy sector, transformation and distribution losses, and the statistical differences [16].

Most of the previous papers covering the research on this topic address the energy consumption in relation to the other macroeconomic indicators. However, the analysis of the share of RES and their consumption in final consumption of energy was not carried out a lot before. This indicator (which is defined by Eurostat) is computed at the final gross energy consumption, including the final energy consumption. Our analysis provides some new insights since it offers the empirical evidence on the share of renewable energy consumption in relation to the GDP per capita. To be best of our knowledge, the majority of the previous studies connected the indicator only to the economic growth and neglected the connection between the share of renewable energy consumption and the GDP per capita. 
From a certain economic point of view, the differences in RES supply are explained by the regional gaps in costs. For example, wind is cheaper on coastal regions and in the Northern Europe, while PV has comparative advantage in the South. Regions with more forests can provide cheap biomass. Regions with mountains and lots of moving water ensure cheaper hydro. Without omitting these regional gaps, our paper does not focus on regional gaps since official regional data are not available for assessing economic costs. We focus on the relationship between the real gross domestic product (GDP) per capita and the share of renewable energy in final energy consumption because these data at national levels are available.

Our paper is organized as follows: Section 2 provides details on theoretical background with references from the research literature, while the methodology and the empirical model are presented briefly in Section 3. In Section 4, we report the results of the empirical model estimations. Section 5 provides some relevant comments and insights on the obtained results. Finally, in the last section (Section 6), we present conclusions, implications, and highlight pathways for further research.

\section{Literature Review}

In sum, final energy consumption from all available resources consists of RES, as well as oil products, gas, solid fuels, nuclear heat, electrical energy, and waste. It embraces the total energy consumption in the transport, industry, and other energy sectors [17]. Final energy consumption from RES includes solar energy (photovoltaic, thermal, and concentrate), wind energy, hydroelectric power, geothermal energy, tidal power, biofuels, as well as the renewable part of waste.

EU Member States closely watch the final energy consumption from all traditional and renewable sources in order to assess the $40 \%$ GHG emission reduction by 2030 target [18]. This commitment makes the EU states to introduce different measures aimed at encouraging the deployment of RES.

With regard to the above, Sadorsky described two empirical models for assessing the relationship between the consumption of renewable energy and income in the emerging economies [19]. He detected a cointegration relationship and demonstrated that the real per capita income growth yielded a positive and significant relationship with the per capita renewable energy consumption. He confirmed that if the real income per capita rises by $1 \%$ in the long run, the renewable energy per capita consumption in the emerging economies also rises by $3.5 \%$.

There is a plethora of studies [20-28] that focus upon the relationship between renewable energy consumption and different macroeconomic variables applying various perspectives and methodologies. More studies investigated the connection between RES and economic growth mainly attributed to the GDP. The majority of these papers revealed a long-run relationship between economic growth and the volumes of used RESs. Few publications showed the significant role of RES to economic growth or attempted to determine the variables that stimulate the others. In most of the cases, GDP acts like dependent variable, while RES consumption, labor force gross and fixed capital formation (GFCF) are the most frequent predictors (see Svenfelt et al. [29], Aslan [30], Sasana and Ghozali [31] or Destek and Aslan [32]).

Some of the papers mentioned above came up with a renewable energy sustainability index which was computed for the EU-15 countries with various levels of the final energy consumption and economic development [20]. Another interesting study focused on studying the per capita energy in the case of 19 Eurozone countries [21]. Moreover, there are many studies explaining the relationship between the energy consumption and a number of macroeconomic indicators, such as the economic growth (in the case of EU-28 countries [22], new EU member states [23], Gulf Cooperation Council (GCC) countries [24], 42 developing countries [25], leading countries with the highest shares of RES in the entire world [26], a sample of the 15 ex-Communist countries [27], nine South and Southeast Asian countries [28], China [33], Algeria [34]), capital and labour (new EU member states [35]), technological innovation (China [36]), urbanization (China [37]), carbon dioxide emissions and financial development (Gulf Cooperation Council (GCC) countries [38]), residential sector [39]). Liddle and Lung [40] identified few groups of countries according to energy consumption and GDP using data for 
countries with different degree of development. In a previous study, a comparison between all EU countries according to their share of energy from renewable sources in gross final consumption was made using different mathematical models [8]. The countries' performance appears to be different: Finland and Sweden reached their target for the gross final energy consumption, while in the same time Denmark, Austria, and Latvia reached the 2020 target for the share of energy obtained from RES in their gross final consumption. Some EU countries have minimum changes to achieve the 2020 targets (Netherlands, Luxembourg, France, Belgium, UK). Other studies provided forecasts on energy consumption considering based on the relationship with economic growth, import, export, financial development, and capital in Japan [41], or China [37].

The different effects of renewable and non-renewable energy consumption are considered in the case of OECD countries [42], some OIC countries [43], and China [44]. The benefits of renewable energy technologies are mostly analysed for emerging countries [23].

We used GDP per capita as a proxy for economic development while other studies employed other variables: economic growth [22-25] and GDP [19]. We employ the share of renewable energy consumption in final energy consumption, while other studies proposed other proxies for the renewable energy consumption: gross final energy consumption [8], renewable energy consumption [19], per capita renewable energy consumption [20], or the and renewable energy sustainability index [21].

Considering the EU Commission's commitment to increase the share of RES consumption in the final energy consumption, the objective of our paper is to analyse the evolution of the share of final energy consumption from RES in the connection with the GDP per capita used as a measure of living standard and income in the EU between 2007 and 2017. Even though the advantages of RES for the environmental protection and reduction of GHG emissions are quite obvious, our research investigates the impact of GDP per capita (as the independent variable) on the share of renewable energy consumption in the final energy consumption (dependent variable). We achieve this by carrying out the empirical research in two main directions: i) the explanation of the share of the renewable energy consumption in the final energy consumption based on the GDP per capita using panel data models and checking Granger causality on the stationary panel data, and ii) the study of the groups of the EU countries according to their share of the renewable energy consumption in the final energy consumption using the cluster analysis.

\section{Methodology and Empirical Model}

As described above, in this paper we focus on the share of RES in the final consumption relative to the real GDP per capita in all EU-28 countries. Our empirical approach is based on two main methods: (i) different panel data models that contain a study of the causality in the panel, and (ii) cluster analysis aimed at unveiling the groups of countries grouped by their shares of renewable energy in the final consumption and their levels of economic development expressed by the GDP per capita.

In order to achieve that we employ some traditional panel data models: fixed-effects model, random-effects model, and the model based on generalized estimating equation (with the latter being used to describe the structure of the within-panel correlation). The last model corresponds with a population-averaged (or marginal) model from the panel-data literature.

The fixed-effects model can be presented in the following general form:

$$
\mathrm{Y}_{\mathrm{it}}=\alpha+\mathrm{X}^{1}{ }_{\mathrm{it}} \cdot \beta_{1}+\ldots+\mathrm{X}^{\mathrm{K}}{ }_{\mathrm{it}} \cdot \beta_{\mathrm{K}}+\mu_{\mathrm{i}}+v_{\mathrm{it}}
$$

where $\mathrm{Y}$ is the dependent variable, $\mathrm{X}$ - exogenous variables, $\mathrm{i}$-index for country, $\mathrm{t}$ - index for year, $v_{\mathrm{it}}$-idiosyncratic error, and $\mu_{\mathrm{i}}$ - the error term for cross-sections

Here, the fixed-effect model makes the following assumptions:

- $\quad$ unobservable individual effects are seen as the fixed parameters;

- $\quad$ the exogenous variables are uncorrelated with idiosyncratic error $\mathbf{v}_{\mathbf{i t}}$, but correlated with fixed individual effects; 
- $\quad$ independent and identically distributed idiosyncratic errors vit(iid( $(0, \sigma 2 \mathrm{v}))$.

In addition, the random-effects model has the following assumptions:

- unobservable individual effects are seen as random variables;

- $\quad$ the exogenous variables are uncorrelated with idiosyncratic error $\mathbf{v}_{\mathbf{i t}}$ or with individual effects;

- $\quad$ independent and identically distributed idiosyncratic errors vit $(\operatorname{iid}(0, \sigma 2 \mathrm{v}))$.

For one explanatory variable, the model can be presented as follows:

$$
\mathrm{Y}_{\mathrm{it}}=\alpha+\mathrm{X}_{\mathrm{it}} \cdot \beta+\mu_{\mathrm{i}}+\mathrm{v}_{\mathrm{it}}
$$

We compute the mean time as the following:

$$
\operatorname{average}\left(Y_{i}\right)=\alpha+\operatorname{average}\left(X_{i}\right) \cdot \beta+\mu_{i}+\operatorname{average}\left(v_{i}\right)
$$

With the difference between the two equations above calculated as follows:

$$
\mathrm{Y}_{\mathrm{it}}-\operatorname{average}\left(\mathrm{Y}_{\mathrm{i} .}\right)=\left(\mathrm{X}_{\mathrm{it}}-\operatorname{average}\left(\mathrm{X}_{\mathrm{i}}\right)\right) \cdot \beta+\left(\mathrm{v}_{\mathrm{it}}-\operatorname{average}\left(\mathrm{v}_{\mathrm{i}}\right)\right)
$$

It becomes apparent that this internal transformation is required for computing the fixed-effect estimator. We apply the least squares method in the model (4) to determine the estimators for $\beta$ with fixed effects. In addition, we check the Granger causality in panel data starting from the following regression:

$$
\mathrm{Y}_{\mathrm{it}}=\alpha_{\mathrm{i}}+\sum \mathrm{Y}_{\mathrm{i}(\mathrm{t}-\mathrm{k})} \cdot \beta_{\mathrm{ik}}+\sum \mathrm{X}_{\mathrm{i}(\mathrm{t}-\mathrm{k})} \gamma_{\mathrm{ik}}+\varepsilon_{\mathrm{it}}
$$

It is established that the data series for the two variables for which the causality is checked have to be stationary. The coefficients have to vary across countries (in this case, $t$ is the index for time, $\mathrm{i}$ is the index for countries) however otherwise remain constant over time. The lag order is $\mathrm{K}$ and it does not change remaining the same for all the countries in the balanced panel. We employ the Granger causality test for identifying the significant effects of the previous values of one variable on the actual values of the second variable. The null hypothesis can be represented as follows:

$$
\text { H0: } \gamma_{\mathrm{i} 1}=\gamma_{\mathrm{i} 2}=\ldots=\gamma_{\mathrm{iK}}=0 \quad \mathrm{i}=1,2, \ldots, \mathrm{N} ;
$$

where $\mathrm{N}$ represents the number of cross-sections (in this case, countries)

We employ the cluster analysis for classifying the groups of countries by the GDP per capita and their shares of RES in their final consumption. In order to do so, we apply a non-hierarchical classification with $\mathrm{K}$-mean clusters. The $\mathrm{k}$-average method starts with the $\mathrm{k}$ values that are used to form the groups. The distance to the cluster is determined based on the Ward method that can be explained as follows:

- $\quad$ for each variable, the sum of the squares for deviations of each country in the cluster from average is calculated, in order to minimize the square of error squares (for example, to minimize the loss of information);

- at any step, the pair of countries that could be joined in a particular cluster is analysed and the pair are unified as to have minimum loss of information.

We do not possess a strong statistical criterion in order to compute the number of clusters that should be considered with a certain probability. Thence, we select the optimal number of clusters based on the aspects such as: results of variance analysis, theoretical motivation, previous utilisation of non-hierarchical methods, and graphical representation of the countries. The k-means methods are carried out following the four consecutive steps:

(1) k initial classes are considered (there is one class for each country); 
(2) a country is relocated in that cluster for which the average is the closest;

(3) the average is recomputed for the two clusters in which that country was;

(4) the previous two steps are redo until changes are made.

\section{Model Estimations and Results}

Our approach uses the share of renewable energy in the final consumption (\%) as dependent variable and GDP per capita (constant 2010 US dollars) as independent variable. The data on these variables was collected for the sample of the EU-28 countries covering the period 2007-2017. The RES share of renewable energy in final consumption data was obtained from Statista, while the data on GDP per capita values was collected from the World Bank.

All EU countries registered a tendency for the growth in the GDP per capita in the period 2007-2017. However, Greece faced some difficulties in 2016 when GDP per capita decreased by $2.47 \%$ compared to previous year, but the increase was resumed in 2017 when GDP per capita grew by $2.03 \%$ compared to 2016. The austerity measures brought Greece into one of the deepest economic depression in its entire modern history. The hard austerity is also supported by the improvement in primary fiscal balance by more than $14 \%$ of GDP in the period 2009-2017 despite the economic recession. The Greek economy returned to its growth only in 2017. As expected, Luxembourg registered the highest value for GDP per capita in 2015. This country has the most competitive economy in the world due to diversified industrialization and intensive export.

Our two main objectives were reached by using the following empirical analysis:

- Investigating the relationship between the share of renewable energy in final consumption (dependent variable) and the GDP per capita (explanatory variable) using panel data models and the Granger causality;

- Classifying groups of the EU-28 countries according to their share of renewable energy in final consumption and GDP per capita in 2007-2017.

In the beginning, the panel data were checked for stationarity and the Levin-Lin-Chu showed stationary data for both variables at $10 \%$ level of significance. Then, we constructed more panel data models in order to explain the RES shares in the EU-28 final consumption during 2007-2017, as we can see in Table 1. Random-effects and fixed-effects models, as well as generalized linear model were applied. All the models confirmed that an increase in the GDP per capita by one unit determined an increase in the RES share in the final consumption by almost 0.0005 percentage points. To put it differently, an increase in the GDP per capita by 10,000 constant 2010 US dollars is necessary to increase the share of renewable energy in the final consumption by 5 percentage points. This result showed that some other factors have to influence the growth of the share of renewable energy in the final consumption maintaining the concern for the growing GDP per capita. These factors might be represented by: progress in the transport sector, market conditions (costs, resource availability, diversity etc.), policy decisions, including the financial support to make renewable energy cost-competitive. We introduced covariates like degree of urbanization and environmental taxes as a share of GDP as covariates in the model, but these variables did not have a significant impact on the dependent variable (the share of renewable energy in final consumption).

Nevertheless, the Granger causality test on stationary panel data showed that the real GDP per capita was an actual cause for changes in the share of renewable energy in final consumption. Moreover, the increase of RES in the electricity did not cause an increase in the living standard in the EU-28 countries (with a GDP per capita used as a proxy). The Granger causality test is run on stationary data sets at $5 \%$ level of significance and the results are presented in Table 2. If p-value is lower than 0.05 , the null hypothesis is rejected. In this case, the p-values are higher than 0.05 and the null hypothesis is not rejected in both cases. 
Table 1. Panel data models to explain the share of renewable energy in final consumption in the EU-28 countries (2007-2017).

\begin{tabular}{cccccccccc}
\hline \multirow{2}{*}{ Variable } & & \multicolumn{3}{c}{$\begin{array}{c}\text { Generalized Estimating } \\
\text { Equation }\end{array}$} & \multicolumn{2}{c}{$\begin{array}{c}\text { Random-Effects GLS } \\
\text { Equation }\end{array}$} & Fixed Effects (within) Regression \\
\hline & Coef. & $\begin{array}{c}\text { Chi-square } \\
\text { stat. }\end{array}$ & p-value & Coef. & $\begin{array}{c}\text { Chi-square } \\
\text { stat. }\end{array}$ & p-value & Coef. & $\begin{array}{c}\text { Chi-square } \\
\text { stat. }\end{array}$ p-value \\
GDP per capita & 0.0005 & 8.22 & 0.000 & 0.0005 & 8.80 & 0.000 & 0.00049 & 7.80 & 0.000 \\
Constant & 2.536 & 0.84 & 0.400 & 0.976 & 0.56 & 0.574 & 3.132 & 1.15 & 0.251 \\
\hline
\end{tabular}

Own results.

Table 2. Granger causality test to check the relationship between the share of renewable energy in final consumption in the EU-28 countries and GDP per capita (2007-2017).

\begin{tabular}{ccc}
\hline Hypothesis & Chi-Square & Prob. \\
\hline Share of renewable energy in electricity does Granger cause GDP per capita & 2.307 & 0.3155 \\
GDP per capita does Granger cause share of renewable energy in electricity & 3.039 & 0.218 \\
\hline
\end{tabular}

Own results.

It becomes apparent from Figure 1 that Sweden remains the country with the highest share of RES in the final consumption in 2007 and 2017. It is followed by Latvia in 2007 and Finland in 2017. Malta had the lowest share of renewable energy in electricity in 2007 (0.2\%), followed by the UK with a share of $1.5 \%$ in 2007 . However, after 10 years, all the countries improved their share of RES in the final energy consumption.

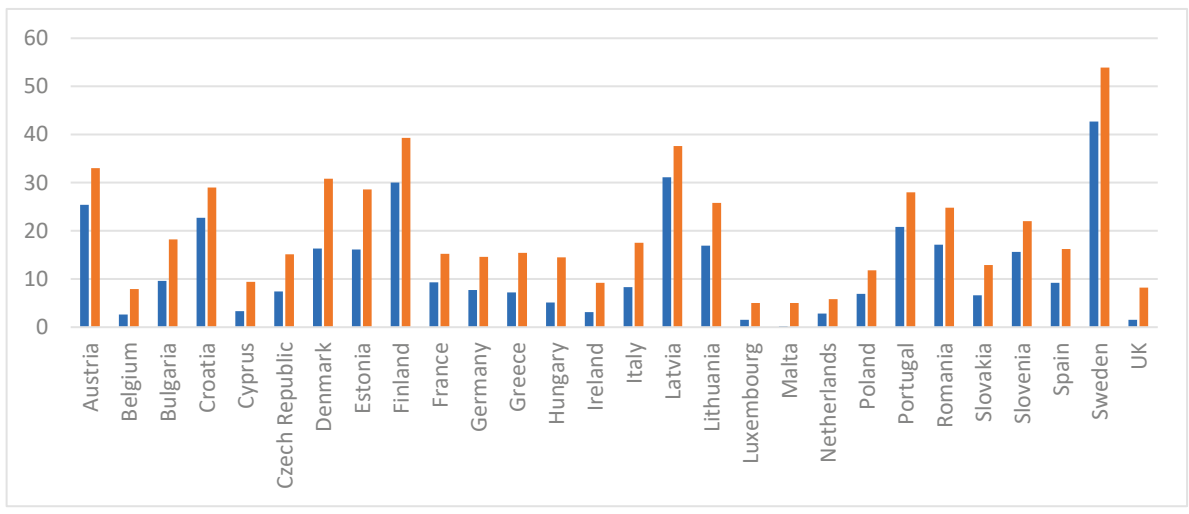

Figure 1. Share of renewable energy in final consumption in 2007 and 2017 in the EU-28 countries (blue-2007, orange-2017). Source: Own results.

More groups of countries were identified according to share of renewable energy in the final consumption and GDP per capita (Tables 3 and 4) in 2007 and 2017. 


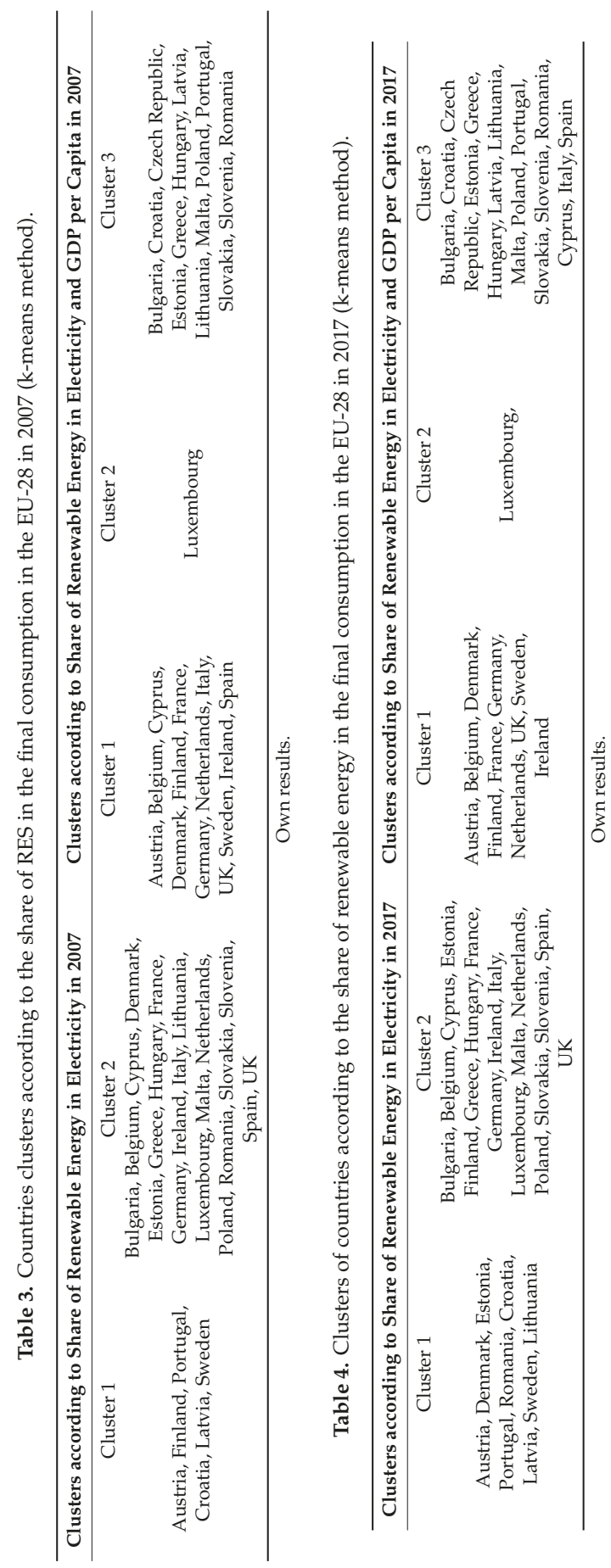


According to Table 3, two groups of countries were identified based on the values of the share of renewable energy in the final consumption in the EU-28 in 2007 (the k-means method was used to build the groups). The first group includes countries with high shares of renewable energy in the final consumption: Austria, Croatia, Portugal, Latvia, Finland, and Sweden. For these countries, the share is more than $20 \%$, the highest share being registered by Sweden (42.7\%) [45].

More than $50 \%$ of the energy used in Sweden is based on the renewable energy sources. In 2012, this country achieved the target of $50 \%$ that was established by the government for 2020 . Sweden is the country that succeeded in combining high energy consumption with low carbon emissions. This performance is due to the rich supply of moving water and biomass. The most used renewable sources in Sweden are water, mostly for electricity production, and bioenergy mostly for heating. Austria is the first European country in hydropower utilization, offering a dynamic business environment to innovative firms. Bioenergy is the most important renewable energy source in Austria [46]. Sweden promoted renewable electricity by applying a subsidy scheme, quota system, and specific tax regulation mechanisms. Renewable heating is stimulated in Sweden by the tax exemptions. The same incentives are used in transport sector for promoting the use of biofuels. In Sweden, electricity generation systems have to be connected to the grid. Companies in the field are obliged to connect a heating plant. In case of lack of any agreement, the operator of district heating network has to ensure usual grid access to this heat generation plant. In the domain of wind energy, Sweden promotes policies for the construction, installation and utilization of RES installations.

Biofuel (wood) appears to be the most crucial individual energy source in Finland. The expansion of this source might be due to the waste wood from the forest industry and burning of its by-products. In the total energy consumption, the wind power has a low share in Finland, lower than biofuels in road transport [47]. Quota system is also applied in Finland in transport sector. Cost effective development of RES in Finland is promoted by tender based premium scheme. Moreover, state subsidies are offered to enhance the investment in RES. "Heat bonus" is provided for CHP plants based on wood fuel and biogas. Policies were developed to support the acquisition and utilization of RES installations.

In Portugal, renewable source that produced more electricity is represented by wind, being followed by water, sun and biofuels [48]. The consumption of electricity based on hydropower is conditioned by weather conditions. A feed-in tariff (FiT) is used in Portugal to promote electricity from renewable sources from plants. Tax exemption applies to small producers of biofuels and quota system is used for biofuels. What concerns the access of electricity from RES to grid shall, priority is given to this type of electricity to the detriment of traditional one, excepting hydro plants having a capacity higher than $30 \mathrm{MW}$.

Croatia stipulated that the share of renewables in gross final consumption of energy would reach $20 \%$ by 2020 , but this target was already surpassed before 2020. In Croatia, wind and solar PV energy developed faster than hydropower and solar thermal [49]. A guaranteed feed-in tariff and a premium tariff are used in Croatia to promote electricity from RES. Special provisions are assigned to electricity from wind power plant. RES installers benefited from a training program to promote electricity and heating based on RES.

Latvia has hydropower and biomass as its most frequently used renewable energy sources. However, wind power and solar energy should be developed more in the future. A complex support system is applied in Latvia to promote electricity based on RES. This system includes quota system, feed-in tariff, and tenders. However, high suspicions of corruption eliminated the feed-in tariff since January 2020. Two policies were implemented to support the installation and utilization of RES installations. Different tax benefits are assigned to cooling and heating based on RES. Companies are obliged to sell diesel and oil mixed with biofuels.

In 2017, Finland does not appear anymore in the group of countries with the high share of renewable energy in the final energy consumption. However, considerable progress was made by Denmark, Romania and Lithuania. Denmark is among the countries of the world with the highest 
consumption of energy coming from wind power, while hydropower still needs exploitation in this country [50].

The natural potential of Romania in producing and consuming energy based on renewable sources is justified by its geographic location and climate. The sources are represented by the biomass resources that account the highest share in renewable energy consumption, wind and solar PV power plants, wind with opportunity to build offshore wind farms, and the solar potential [51]. Romania uses quota system to promote electricity from RES. The financial support for the new installations in this field ceased at the end of 2016 because of significant financial losses registered by producers. Emergency ordinances were emitted to eliminate legal uncertainties and to promote transparency of the support scheme based on Green Certificate. Other policies promote RES-H infrastructure development and training programs for RES installers.

Starting from the proposed panel data, some scenarios were made for the share of renewables in gross final consumption of energy in 2020. The final scenario is an average of the scenarios corresponding to the three panel data models. For providing the forecasts for the share of renewable energy in the final consumption, we used predictions for GDP per capita for 2020 made by Trading Economics (see Table 5).

Table 5. Scenarios for the share of renewable energy in final consumption (\%) in the EU-28 in 2020.

\begin{tabular}{cc}
\hline Country & Share of Renewable Energy in Final Consumption in 2020 (\%) \\
\hline Austria & 37.6 \\
Belgium & 8.8 \\
Bulgaria & 20.1 \\
Croatia & 33 \\
Cyprus & 10.7 \\
Czech Republic & 16.7 \\
Denmark & 33.2 \\
Estonia & 30.5 \\
Finland & 44.3 \\
France & 17.3 \\
Germany & 16.1 \\
Greece & 16.7 \\
Hungary & 15.7 \\
Ireland & 11.2 \\
Italy & 18.9 \\
Latvia & 40.1 \\
Lithuania & 27.4 \\
Luxembourg & 6.6 \\
Malta & 6.8 \\
Netherlands & 7.2 \\
Poland & 13.3 \\
Portugal & 29.5 \\
Romania & 27.3 \\
Slovakia & 14.1 \\
Slovenia & 25 \\
Spain & 18.8 \\
Sweden & 56.7 \\
UK & 9.6 \\
\hline
\end{tabular}

Own results.

As we initially expected, many countries are going to have difficulties in achieving the required EU targets. An increase in the share of renewable energy in final consumption is expected in 2020 compared to 2017, but other measures are necessary to accelerate the growth. Countries that have already achieved the targets will continue to yield increase, but low performers need to revise the measures to achieve the national targets. 


\section{Discussion of Results}

RES play a strategic role in the European sustainable agenda. This paper comes up with the quantitative analysis that might be useful for the decision-makers. Usually, the performance of RES is evaluated by benefits related to the environment protection and less to the GHG emissions. However, these effects should also be analysed by the means of real GDP per capita. The validity of our results is confirmed using the historical data as well as some advanced statistical methods. Our work stresses the importance of using larger amounts of RES for improving the living standards [52-57].

The EU countries were divided into two groups with respect to their share of renewable energy in the final energy consumption. This research indicates that two urgent measures should be taken. One measure might be a policy action to support the expansion of RES in the countries with the lower shares of renewable energy in the final energy consumption. The second measure should emphasize that RES and energy efficiency determine the evolution to a low-carbon society. The levels of energy based on RES should be in accordance with the citizens' and firms' needs from the economic point of view, without neglecting the environmental effects.

One important strategy for the EU is to lower the final energy consumption. This represents an objective that might be reached by improving the energy efficiency and increasing the share of RES in final energy consumption. If the final energy consumption is reduced, the other goals are achieved: progress in sustainable development, more environment protection, less global warming, and the decrease in the dependence on energy imports.

Our main outcome is that EU's energy consumption based on RES has been continually and significantly growing. This represents the fact that made us to accept the decrease in the traditional energy consumption, which might arrive below the established target in 2020. Even if the EU countries increased their share of the renewable energy consumption in their final energy consumption, there would be different patterns for various European countries.

Therefore, every EU country established its own 2020 target which was based on specific characteristics, economic performance, and the potential for the use of renewable sources in consumption [56-58]. As a result, starting from 2007, the share of energy from RES in the final energy consumption has been rising for all EU Member States. It becomes obvious that many EU states have to increase their share of RES in order to achieve their national energy consumption targets in order to comply with the EU strategy. Some changes in the national renewable energy action plans and policies are needed without neglecting the essential support from the EU. If this is not done, the gaps between the EU countries might intensify and only some countries would continue to increase their shares of RES in their final energy consumption. It is apparent that the immediate consequences are related to the distortion and fragmentation of the national energy market which might results in the higher costs and lower usage of RES in the EU as a whole [59].

Considering the actual energy market architecture, some authors explain that the renewable energy will be less scalable and more expensive in the future [60-65]. The established goal (100\% transition to renewable electricity sector) will not be achieved. An increase in the market share of renewable energy required a successful co-existence between the fossil fuels and the renewable energy [66].

\section{Conclusions and Implications}

All in all, it can be established that starting from 2010, the increase in the renewable energy consumption has become quite significant. This was the time when massive investments into the development of RES were made in the EU Member States after the EU Directive that was accepted just a year earlier. Even if all the EU Member States are following the upward trend, reaching the 2020 target is not certain because since 2015 the investment in RES production has halted. Countries like Spain and Belgium focused more on RES for generating their electricity with the rest of the energy consumption based on traditional carbon fuels. Poland made important progress in the consumption of RES but needs to develop the production from RES further to achieve the 2020 target. For Austria, Finland, Denmark, and Sweden RES occupy an important place in their energy mix. All these countries have 
climatic conditions and lack of fossil fuel resources that impose on the society and industry the pressing need to minimize the energy consumption. New EU commitments were established in the Directive (EU) 2018/844/ for 2030: GHGs reduction by at least $40 \%$ compared to the values registered in 1990, improvement in EU competitiveness, energy security and sustainability, more energy savings, and the increase in the share of RES consumption. Within this context, consistent efforts should be made by all EU countries. In the United Kingdom, significant efforts were made to increase the production of RES, especially by expending the technologies for solar power, but in spite of this the EU target seems to be far away. The uncertainties generated by the Brexit detracted the interest for the renewable growth among Brits. The political rhetoric and practical decision-making focused more on the issue of coal. Germany is a country that made formidable development in the consumption of fossil and nuclear fuels, but even there problems prevail. However, the urgency of phasing out coal in Germany has been ignored for many years. Oei et al. (2020) showed that in 2007, Integrated Energy and Climate Programme (Integrierte Energie-und Klimaprogramm) became the main reference in climate policy in Germany. It fixed as target the reduction of emissions by $40 \%$ in 2020 [67]. Moreover, it should be mentioned that France and Italy experience serious issues with achieving the EU 2020 RES targets. The Netherlands also report some problems due to the fact that its final energy consumption is largely based on a natural gas network with the gas being cheap at the moment. Furthermore, government RES subsidies are not attractive and are lower in comparison with the Scandinavian countries. On the other side of the EU, Portugal pumped funding into RES, but the costs were high and prevented a high increase in the share of energy from the renewable sources from one year to another. Czech Republic, Hungary, and Romania all boast high shares of RES and even increased their efforts to meet the EU targets after their EU accession in 2004.

Nevertheless, there are also some EU countries in which the RES 2020 target in gross final consumption was exceeded: Czech Republic since 2013, Sweden and Bulgaria since 2012, Hungary and Estonia since 2011, and Romania, Lithuania, Italy, and Finland since 2014. One important objective of this paper was the study of the relationship between the share of the renewable energy in the final energy consumption and real GDP per capita. Many previous studies only considered the relationship between economic growth and (RES) energy consumption. We selected the GDP per capita instead of economic growth because we consider the GDP per capita to be an indicator that better describes the long-run development. The economic growth presents high fluctuations, especially in the times of the economic crisis but the standard of living of population is more stable without high fluctuations from one year to another. Moreover, this indicator is followed not only by all citizens, but also by the governments and the firms. One important result following from our study is that the real GDP per capita was a real cause for the growth in the share of the renewable energy in the final energy consumption. This means that countries with high GDP per capita will have a higher share of renewable energy in the final consumption. All the panel data models indicated a positive but also small impact of GDP per capita on the share of renewable energy in the final consumption. If wealthier countries used more RES in proportion to their total energy consumption, their energy security would be improved and the sustainable development would be consolidated. This involves the access to more sustainable, reliable and modern energy. The sustainability of a country has been a priority in line with the goal to reduce the dependency on the non-renewable sources of energy.

The results of this research confirmed that higher standard of living in a country could enhance the energy consumption based on RES. However, other latent factors could contribute to the intensive utilization of RES in energy production and consumption. Some of these factors related to social and fiscal aspects, like urbanization and environmental taxes, were not relevant in explaining energy consumption based on RES. Other factors did not have quantitative measures that could be introduced in the econometric models, but they had a strong impact on RESs. One relevant example could be the specific policies in the field that were applied in each EU country. Appropriate policies to promote RES were described for the countries with the high share of renewable energy in the final energy consumption. For example, quota system is intensively applied in Sweden, Finland, Latvia, 
Romania and in Portugal only for biofuels. A feed-in tariff was implemented in Portugal, Croatia and Latvia. In all these countries investments were made to promote the acquisition and utilization of RES installations. Sweden obtained the best performance, because more types of incentives were applied. Some of these incentives refer to all RESs (subsidy scheme, quota system, and specific tax regulation mechanisms) while other ones focus on specific RESs (tax exemptions for renewable heating and biofuels production). However, improvements should also be brought to these policies in order to achieve the new targets for 2030.

It appears that a considerable increase in the GDP per capita is required in order to increase the share of RES in the final energy consumption. The scenarios for 2020 revealed notorious difficulties represented by the low performances in achieving a significant increase of RES in the final consumption and the expectations are confirmed, since some EU countries are not capable to achieve the EU required targets set up for 2020 .

The pathways for the future research might continue in two main directions: First of all, there might arise some policy proposals for establishing funding opportunities for the EU countries according to the progress in achieving the national targets. Secondly, setting a rule is necessary for directing more economic benefits to those countries with high performance in achieving the RES target share in the final energy consumption. Following the first proposal, we should focus more on the economic, social, environmental, political, and technological factors regarding string and weak points and the capacity for using more RES. Following the second proposal, we should analyse more the situation of the states with the best performance. All in all, it is necessary to evaluate the effect of more factors on RES development: internal energy production, technological development, investment in research and development, foreign dependence, community policies, subsidy policy, industrial know-how, as well as citizens' openness to doing business and protecting environment [64-80].

Author Contributions: Conceptualization, M.S., W.S. and M.T.; methodology, M.S. and M.T.; formal analysis, M.S. and W.S.; resources, M.S. and M.T.; data curation, M.S. and W.S.; writing-original draft preparation: M.S., W.S. and M.T.; project administration, M.S.; funding acquisition, M.T. and W.S. All authors have read and agreed to the published version of the manuscript.

Funding: The research was partly supported by European Union's Horizon 2020 project H2020-MSCA-RISE-2014 CLUSDEVMED Grant Agreement Number 645730730.

Conflicts of Interest: The authors declare no conflict of interest.

\section{References}

1. Pfenninger, S.; Keirstead, J. Renewables, nuclear, or fossil fuels? Scenarios for Great Britain's power system considering costs, emissions and energy security. Appl. Energy 2015, 152, 83-93. [CrossRef]

2. Wu, Q.; Zhou, J.; Liu, S.; Yang, X.; Ren, H. Multi-objective Optimization of Integrated Renewable Energy System Considering Economics and $\mathrm{CO}_{2}$ Emissions. Energy Procedia 2016, 104, 15-20. [CrossRef]

3. European Parliament. Renewable Energy Sources. 2016. Available online: http://www.europarl.europa.eu/ $\mathrm{ftu} / \mathrm{pdf} / \mathrm{lv} /$ FTU_5.7.4.pdf (accessed on 3 December 2018).

4. Šahović, N.; da Silva, P.P. Community Renewable Energy-Research Perspectives. Energy Procedia 2016, 106, 46-58. [CrossRef]

5. Sinn, H.W. Buffering volatility: A study on the limits of Germany's energy revolution. Eur. Econ. Rev. 2017, 99, 130-150. [CrossRef]

6. Cucchiella, F.; Adamo, I.; Gastaldi, M. Biomethane: A renewable resource as vehicle fuel. Resources 2017, 6, 58. [CrossRef]

7. Sari, A.; Akkaya, M. Contribution of renewable energy potential to sustainable employment. Procedia Soc. Behav. Sci. 2016, 229, 316-325. [CrossRef]

8. Cucchiella, F.; D'Adamo, I.; Gastaldi, M.; Miliacca, M. Efficiency and allocation of emission allowances and energy consumption over more sustainable European economies. J. Clean. Prod. 2018, 182, 805-817. [CrossRef] 
9. Frankfurt School UNEP Centre; Bloomberg New Energy Finance (BNEF). Global Trends in Renewable Energy Investment. Frankfurt School-UNEP Centre, 2016. Available online: http://fs-unep-centre.org/sites/default/ files/attachments/press_release_gtr_2016_in_english.pdf (accessed on 27 October 2019).

10. Blazejczak, J.; Braun, F.G.; Edler, D.; Schill, W.P. Economic effects of renewable energy expansion: A model-based analysis for germany. Renew. Sustain. Energy Rev. 2014, 40, 1070-1080. [CrossRef]

11. IEA. Energy and Climate Change, World Energy Outlook Special Report. Available online: https://www.iea. org/publications/freepublications/publication/WEO2015SpecialReportonEnergyandClimateChange.pdf (accessed on 7 November 2019).

12. Thellufsen, J.Z.; Lund, H. Cross-border versus cross-sector interconnectivity in renewable energy systems. Energy 2017, 124, 492-501. [CrossRef]

13. Ruggiero, S.; Lehkonen, H. Renewable energy growth and the financial performance of electric utilities: A panel data study. J. Clean. Product. 2017, 142, 3676-3688. [CrossRef]

14. Eurostat Statistics Explained. Available online: http://ec.europa.eu/eurostat/statistics-explained/index.php/ Glossary:Gross_inland_energy_consumption (accessed on 16 November 2018).

15. EUR-Lex. Directive 2009/28/EC of the European Parliament and of the Council of 23 April 2009 on the Promotion of the Use of Energy from Renewable Sources and Amending and Subsequently Repealing Directives 2001/77/EC and 2003/30/EC. Available online: http://eur-lex.europa.eu/legal-content/EN/TXT/PDF/ ?uri=CELEX:32009L0028\&from=RO (accessed on 30 September 2018).

16. Soava, G.; Mehedintu, A.; Sterpu, M.; Raduteanu, M. Impact of renewable energy consumption on economic growth: Evidence from European Union countries. Technol. Econ. Dev. Econ. 2018, 24, 1197-1215. [CrossRef]

17. Engelken, M.; Römer, B.; Drescher, M.; Welpe, I.M.; Picot, A. Comparing drivers, barriers, and opportunities of business models for renewable energies: A review. Renew. Sustain. Energy Rev. 2016, 60, 795-809. [CrossRef]

18. Council of the European Union. Tackling Climate Change, the 2030 Climate and Energy Framework, Brussels. Available online: http://data.consilium.europa.eu/doc/document/ST-169-2014-INIT/en/pdf (accessed on 22 September 2018).

19. Sadorsky, P. Renewable energy consumption and income in emerging economies. Energy Policy 2009, 37, 4021-4028. [CrossRef]

20. Collins, S.; Deane, J.P.; Ó Gallachóir, B. Adding value to EU energy policy analysis using a multi-model approach with an EU-28 electricity dispatch model. Energy 2017, 130, 433-447. [CrossRef]

21. European Commission. A Policy Framework for Climate and Energy in the Period from 2020 to 2030; European Commission: Juba, South Sudan, 2014; Eurostat. Statistics Database; Available online: Http://ec.Europa.Eu/ eurostat/data/database (accessed on 22 October 2018).

22. García-Álvarez, M.T.; Moreno, B.; Soares, I. Analyzing the environmental and resource pressures from european energy activity: A comparative study of EU member states. Energy 2016, 115, 1375-1384. [CrossRef]

23. Cucchiella, F.; D’Adamo, I.; Gastaldi, M.; Koh, S.C.L.; Rosa, P. A comparison of environmental and energetic performance of european countries: A sustainability index. Renew. Sustain. Energy Rev. 2017, 78, 401-413. [CrossRef]

24. Štreimikienè, D.; Balezentis, T. Kaya identity for analysis of the main drivers of ghg emissions and feasibility to implement eu "20-20-20" targets in the Baltic States. Renew. Sustain. Energy Rev. 2016, 58, 1108-1113. [CrossRef]

25. Armeanu, D.; Vintilă, G.; Gherghina, Ş. Does renewable energy drive sustainable economic growth? Multivariate panel data evidence for EU-28 countries. Energies 2017, 10, 381. [CrossRef]

26. Liobikienè, G.; Butkus, M. The European Union possibilities to achieve targets of Europe 2020 and Paris agreement climate policy. Renew. Energy 2017, 106, 298-309. [CrossRef]

27. D'Adamo, I.; Rosa, P. Current state of renewable energies performances in the European Union: A new reference framework. Energy Convers. Manag. 2016, 121, 84-92. [CrossRef]

28. Capros, P.; Paroussos, L.; Fragkos, P.; Tsani, S.; Boitier, B.; Wagner, F.; Busch, S.; Resch, G.; Blesl, M.; Bollen, J. Description of models and scenarios used to assess European decarbonisation pathways. Energy Strategy Rev. 2014, 2, 220-230. [CrossRef]

29. Svenfelt, Å.; Engström, R.; Svane, Ö. Decreasing energy use in buildings by $50 \%$ by 2050 -A backcasting study using stakeholder groups. Technol. Forecast. Soc. Chang. 2011, 78, 785-796. [CrossRef] 
30. Aslan, A. The causal relationship between biomass energy use and economic growth in the United States. Renew. Sustain. Energy Rev. 2016, 57, 362-366. [CrossRef]

31. Destek, M.A.; Aslan, A. Renewable and non-renewable energy consumption and economic growth in emerging economies: Evidence from bootstrap panel causality. Renew. Energy 2017, 111, 757-763. [CrossRef]

32. Sasana, H.; Ghozali, I. The impact of fossil and renewable energy consumption on the economic growth in Brazil, Russia, India, China and South Africa. Int. J. Energy Econ. Policy 2017, 7, 194-200. [CrossRef]

33. Resch, G.; Gephart, M.; Steinhilber, S.; Klessmann, C.; del Rio, P.; Ragwitz, M. Coordination or harmonisation? Feasible pathways for a European res strategy beyond 2020. Energy Environ. 2013, 24, 147-170. [CrossRef]

34. Klessmann, C.; Rathmann, M.; de Jager, D.; Gazzo, A.; Resch, G.; Busch, S.; Ragwitz, M. Policy options for reducing the costs of reaching the European renewables target. Renew. Energy 2013, 57, 390-403. [CrossRef]

35. Markaki, M.; Belegri-Roboli, A.; Sarafidis, Y.; Mirasgedis, S. The carbon footprint of Greek households (1995-2012). Energy Policy 2017, 100, 206-215. [CrossRef]

36. Eurostat. Energy from Renewable Sources (Summary-Results-Shares-2014). Available online: http://ec. Europa.Eu/eurostat/web/energy/data/shares (accessed on 5 February 2020).

37. Rezitis, A.N.; Ahammad, S.M. The relationship between energy consumption and economic growth in South and Southeast Asian countries: A panel vector autoregression approach and causality analysis. Int. J. Energy Econ. Policy 2015, 5, 704-715. [CrossRef]

38. Fumon, N.; Biswas, M.A.R. Regression analysis for prediction of residential energy consumption. Renew. Sustain. Energy Rev. 2015, 47, 332-343. [CrossRef]

39. Salim, R.A.; Shafiei, S. Urbanization and renewable and non-renewable energy consumption in OECD countries: An empirical analysis. Econ. Model. 2014, 38, 581-591. [CrossRef]

40. Anwar, A.; Arshed, N.; Kousar, N. Renewable Energy Consumption and Economic Growth in Member of OIC Countries. Eur. Online J. Nat. Soc. Sci. 2017, 6, 111-129. [CrossRef]

41. Liu, Y. Exploring the relationship between urbanization and energy consumption in China using ARDL (autoregressive distributed lag) and FDM (factor decomposition model). Energy 2009, 34, 1846-1854. [CrossRef]

42. Tzeng, G.H.; Shiau, T.A.; Lin, C.Y. Application of multicriteria decision making to the evaluation of new energy system development in Taiwan. Energy 1992, 17, 983-992. [CrossRef]

43. Pappas, S.S.; Ekonomou, L.; Karamousantas, D.C.; Chatzarakis, G.; Katsikas, S.; Liatsis, P. Electricity demand loads modeling using AutoRegressive Moving Average (ARMA) models. Energy 2008, 33, 1353-1360. [CrossRef]

44. Ozturk, S.; Ozturk, F. Forecasting Energy Consumption of Turkey by Arima Model. J. Asian Sci. Res. 2018, 8, 52-60. [CrossRef]

45. Barak, S.; Sadegh, S. Forecasting energy consumption using ensemble ARIMA-ANFIS hybrid algorithm. Electr. Power Energy Syst. 2016, 82, 92-104. [CrossRef]

46. Official Statistics of Finland (OSF): Energy supply and consumption [e-publication]. ISSN=1799-7976. 4th quarter 2017. Helsinki: Statistics Finland. Available online: http://www.stat.fi/til/ehk/2017/04/ehk_2017_04_ 2018-03-28_tie_001_en.html (accessed on 10 December 2018).

47. APREN. Renewable Electricity in Portugal. 2017. Available online: https://apren.pt/../06-renewableelectricity-in-portugal-2.pdf (accessed on 10 December 2018).

48. Borozan, D. Exploring the relationship between energy consumption and GDP: Evidence from Croatia. Energy Policy 2013, 59, 373-381. [CrossRef]

49. Lund, H. Renewable energy strategies for sustainable development. Energy 2007, 32, 912-919. [CrossRef]

50. Câmpeanu, V.; Pencea, S. Renewable energy sources in Romania: From a "paradise" of investors to a possible abandon or to another boom? The impact of a new paradigm in Romanian renewable sources policy. Procedia Econ. Financ. 2014, 8, 129-137. [CrossRef]

51. Yuan, C.; Liu, S.; Fang, Z. Comparison of China's primary energy consumption forecasting by using ARIMA (the autoregressive integrated moving average) model and GM(1,1) model. Energy 2016, 100, 384-390. [CrossRef]

52. Tsai, S.B.; Xue, Y.; Zang, J.; Chen, Q.; Liu, Y.; Zhou, J.; Dong, W. Models for forecasting growth trends in renewable energy. Renew. Sustain. Energy Rev. 2017, 77, 1169-1178. [CrossRef]

53. Würzburg, K.; Labandeira, X.; Linares, P. Renewable generation and electricity prices: Taking stock and new evidence for Germany and Austria. Energy Econ. 2013, 40, S159-S171. [CrossRef] 
54. Rubins, M.; Pilvere, I. Development of renewable energy policy in Latvia. Econ. Sci. for Rural Dev. Conf. Proc. 2017, 44, 281-291.

55. Blecich, P.; Petrić, M.; Franković, B. Renewable energy in Croatia: A review of present state and future development. In Proceedings of the 11th ISES Eurosun Conference, Palma, Spain, 11-14 October 2016.

56. McCollum, D.L.; Zhou, W.; Bertram, C.; De Boer, H.S.; Bosetti, V.; Busch, S.; Fricko, O. Energy investment needs for fulfilling the Paris Agreement and achieving the Sustainable Development Goals. Nat. Energy 2018, 3, 589-612. [CrossRef]

57. Cucchiella, F.; D'Adamo, I.; Gastaldi, M. Future trajectories of renewable energy consumption in the European Union. Resources 2018, 7, 10. [CrossRef]

58. Wang, D.D.; Sueyoshi, T. Climate change mitigation targets set by global firms: Overview and implications for renewable energy. Renew. Sustain. Energy Rev. 2018, 94, 386-398. [CrossRef]

59. Proença, S.; Aubyn, M.S. Hybrid modeling to support energy-climate policy: Effects of feed-in tariffs to promote renewable energy in Portugal. Energy Econ. 2013, 38, 176-185. [CrossRef]

60. Kamran, M. Current status and future success of renewable energy in Pakistan. Renew. Sustain. Energy Rev. 2018, 82, 609-617. [CrossRef]

61. Stefanelli, R.D.; Walker, C.; Kornelsen, D.; Lewis, D.; Martin, D.H.; Masuda, J.; Castleden, H. Renewable energy and energy autonomy: How Indigenous peoples in Canada are shaping an energy future. Environ. Rev. 2019, 27, 95-105. [CrossRef]

62. Burke, M.J.; Stephens, J.C. Political power and renewable energy futures: A critical review. Energy Res. Soc. Sci. 2018, 35, 78-93. [CrossRef]

63. Blazquez, J.; Fuentes-Bracamontes, R.; Bollino, C.A.; Nezamuddin, N. The renewable energy policy Paradox. Renew. Sustain. Energy Rev. 2018, 82, 1-5. [CrossRef]

64. Lund, H.; Mathiesen, B.V. Energy system analysis of $100 \%$ renewable energy systems-The case of Denmark in years 2030 and 2050. Energy 2009, 34, 524-531. [CrossRef]

65. Chirila, N. Renewable energy in Romania. Flanders Invest. Trade 2013, 3, 1-56.

66. Shah, I.H.; Hiles, C.; Morley, B. How do oil prices, macroeconomic factors and policies affect the market for renewable energy? Appl. Energy 2018, 215, 87-97. [CrossRef]

67. Oei, P.Y.; Hermann, H.; Herpich, P.; Holtemöller, O.; Lünenbürger, B.; Schult, C. Coal phase-out in Germany-Implications and policies for affected regions. Energy 2020, 196, 117004. [CrossRef]

68. Şener, Ş.E.C.; Sharp, J.L.; Anctil, A. Factors impacting diverging paths of renewable energy: A review. Renew. Sustain. Energy Rev. 2018, 81, 2335-2342. [CrossRef]

69. Zhao, Z.Y.; Chen, Y.L. Critical factors affecting the development of renewable energy power generation: Evidence from China. J. Clean. Prod. 2018, 184, 466-480. [CrossRef]

70. Tvaronavičienè, M.; Baublys, J.; Raudeliūnienè, J.; Jatautaitè, D. Chapter 1-Global energy consumption peculiarities and energy sources: Role of renewables. In Energy Transformation towards Sustainability; Tvaronavičienè, M., Ślusarczyk, B., Eds.; Elsevier: Amsterdam, The Netherlands, 2020; pp. 1-49. ISBN 9780128176887. [CrossRef]

71. Dudin, M.N.; Frolova, E.E.; Protopopova, O.V.; Andrey Alievich Mamedov, A.A.; Odintsov, S.V. Study of innovative technologies in the energy industry: Nontraditional and renewable energy sources. Entrep. Sustain. Issues 2019, 6, 1704-1713. [CrossRef]

72. Andriushchenko, K.; Buriachenko, A.; Rozhko, O.; Lavruk, O.; Skok, P.; Hlushchenko, Y.; Muzychka, Y.; Slavina, N.; Buchynska, O.; Kondarevych, V. Peculiarities of sustainable development of enterprises in the context of digital transformation. Entrep. Sustain. Issues 2020, 7, 2255-2270. [CrossRef]

73. Chehabeddine, M.; Tvaronavičienè, M. Securing regional development. Insights Reg. Dev. 2020, 2, 430-442. [CrossRef]

74. Masood, O.; Tvaronavičienè, M.; Javaria, K. Impact of oil prices on stock return: Evidence from G7 countries. Insights Reg. Dev. 2019, 1, 129-137. [CrossRef]

75. Sarma, U.; Karnitis, G.; Zuters, J.; Karnitis, E. District heating networks: Enhancement of the efficiency. Insights Reg. Dev. 2019, 1, 200-213. [CrossRef]

76. El Iysaouy, L.; El Idrissi, N.E.; Tvaronavičienè, M.; Lahbabi, M.; Oumnad, A. Towards energy efficiency: Case of Morocco. Insights Reg. Dev. 2019, 1, 259-271. [CrossRef]

77. Pechancová, V.; Hrbáčková, L.; Dvorský, J.; Chromjaková, F.; Stojanovic, A. Environmental management systems: An effective tool of corporate sustainability. Entrep. Sustain. Issues 2019, 7, 825-841. [CrossRef] 
78. Tyo, A.; Jazykbayeva, B.; Ten, T.; Kogay, G.; Spanova, B. Development tendencies of heat and energy resources: Evidence of Kazakhstan. Entrep. Sustain. Issues 2019, 7, 1514-1524. [CrossRef]

79. Rogalev, A.; Komarov, I.; Kindra, V.; Zlyvk, O. Entrepreneurial assessment of sustainable development technologies for power energy sector. Enterp. Sustain. Issues 2018, 6, 429-445. [CrossRef]

80. Böhringer, C. Two decades of European climate policy: A critical appraisal. Rev. Environ. Econ. Policy 2014, 8,1-17. [CrossRef]

(ब) (1)

(C) 2020 by the authors. Licensee MDPI, Basel, Switzerland. This article is an open access article distributed under the terms and conditions of the Creative Commons Attribution (CC BY) license (http://creativecommons.org/licenses/by/4.0/). 
Article

\title{
Examining the Interactive Endogeneity Relationship between R\&D Investment and Financially Sustainable Performance: Comparison from Different Types of Energy Enterprises
}

\author{
Kalon $\mathrm{Si}^{1}$, Xin Long $\mathrm{Xu}^{2, *}$ and Hsing Hung Chen ${ }^{3}$ \\ 1 College of Social Science, Tsinghua University, Beijing 100084, China; sikalon@gmail.com \\ 2 College of Tourism, Hunan Normal University, Changsha, Hunan 410081, China \\ 3 School of Business, Macau University of Science and Technology, Taipa, Macau 999078, China; \\ hhchen@must.edu.mo \\ * Correspondence: xu78744359@gmail.com
}

Received: 1 April 2020; Accepted: 1 May 2020; Published: 7 May 2020

\begin{abstract}
This paper employs the cluster analysis to classify the energy sector into three types, namely, technology-, capital-, and labor-intensive energy company. It then studies the interactive endogenous relationship between $R \& D$ investment and financially sustainable performance and the moderate effect of the executive incentive through three-stage least squares (3SLS) of the simultaneous equations model (SEM). The results show that for the technology-intensive energy company, an increase in the previous period in R\&D investment improves the current period of financially sustainable performance, and the improvement in the current period in financially sustainable performance results in a decline in financially sustainable performance in the next period, which demands an increase in R\&D investment subsequently. In contrast, for the capital-intensive energy company, R\&D investment can significantly improve the financially sustainable performance in the current period, and the improvement in financially sustainable performance can also promote the intensity of next period R\&D investment. For the labor-intensive energy company, R\&D investment depends on the company's previous period returns, while R\&D investment has no significant impact on the financially sustainable performance in the current period and the next period. In addition, the salary incentives for executives have a significant positive moderate effect on the relationship between R\&D investment and financially sustainable performance, especially in the technology-intensive energy company, while equity incentives for executives do not show any significant effect in the sample for different types of companies.
\end{abstract}

Keywords: R\&D investment; financially sustainable performance; executive incentive; endogenous relationship; energy enterprises

\section{Introduction}

Nowadays, the energy system in the world is mainly based on fossil fuels, nuclear energy and hydropower [1,2]. This system has been highly resilient against external shocks over the past few decades, but is facing a variety of challenges at present. In the wake of the 1970s oil crisis and owing to ascending carbon dioxide concentrations in the atmosphere, concerns about the security of supply and the sustainability of the concurrent regime are rising. In addition, after relentless nuclear accidents in Chernobyl in 1986 and Fukushima in 2011, several countries decided to opt out of nuclear power [3]. All of these cases expedite the on-going transformation of the energy system and the strengthening development of renewable energy technologies [4]. One of the driving forces behind this transformation is innovation [5]. Faced with complex environments and the changing market 
demand, the energy industry should strive to increase investment in innovations [6,7] and explore an effective executive incentive system to enhance its core competitiveness and promote corporate sustainable development [8].

As modern enterprises, most energy companies, however, have a principal-agent problem of ownership-management separation. Shareholders tend to pursue high returns of technological innovation, and realize the long-term development of companies through innovations, and finally achieve the goal of maximizing corporate value [9]. In contrast, managers are more inclined to focus on activities related to short-term interests such as their own salaries and benefits. Therefore, managers are likely to avoid technological innovations in pursuit of short-term benefits due to the characteristics of technological innovation such as uncertainty, high risk, and a long profit cycle [10]. This results in insufficient investment in corporate R\&D projects, which is unfavorable to the sustainable growth of energy companies [11]. Therefore, how managers balance the relationship between the short-term profits and the sustainable development becomes a main factor affecting the decision-making of R\&D investment.

The existing literature suggests that R\&D investment can promote corporate financially sustainable performance [12-14]. However, few studies focus on whether corporate R\&D intensity can be maintained, or whether current corporate performance can trigger managers' short-sighted behaviors such as reducing R\&D expenditure. According to the principal-agent theory, managers may prefer to have behaviors that are beneficial to their positions and interests but not for the maximization of corporate value in an information asymmetrical environment [10]. Financially sustainable performance appraisal is one of key indicators determining the managers' retention $[13,15]$. Therefore, the managers usually try to increase corporate profits while cutting costs to achieve current target performance [16]. This phenomenon will undoubtedly induce managers to deliberately reduce the current cash expenditures in R\&D investment and other activities with high uncertainties in order to achieve target financial performance, thus jeopardizing the long-term development objectives of the company. Therefore, it is necessary to study the impact of R\&D investment on financially sustainable performance and the interactive endogenous relationship between R\&D investment and financially sustainable performance.

Managers play a leading role in innovation activities of energy companies. The effective executive incentive mechanism is a critical factor ensuring corporate R\&D investment [17]. Since managers' return is mainly derived from the short-term salary income and the salary income depends on the short-term financial performance of the energy companies, managers are often not in favor of R\&D projects due to the high risks and uncertainty [18]. Therefore, it is an important choice for shareholders to implement the executive incentive to improve the risk-taking ability and enhance the core competitiveness of energy companies. In recent years, a lot of studies have focused on the impact of equity incentives and salary incentives of executives on R\&D investment and financially sustainable performance [19-21], but no consistent conclusions have been drawn. In addition, there is little literature on the interactive endogenous relationship between R\&D investment and financially sustainable performance. Some questions need to be asked. Will other production factors impact on the economic returns from point of the view of R\&D investment in the energy sector? How is financially sustainable performance reversely reflected by the period and intensity of $R \& D$ investment? Are the moderate effects of different types of executive incentive on the relationship between R\&D investment and financially sustainable performance consistent? Therefore, all these issues need to be further discussed to expand the research field of innovation performance and beneficial to optimize and update the energy industry structure.

The contribution of this paper is as follows. First, this paper studies the interactive endogenous relationship between $R \& D$ investment and financially sustainable performance and focuses on the reverse effect of financially sustainable performance on R\&D investment. This will fill the gap of research on the effect of financially sustainable performance on R\&D investment in the existing literature. Secondly, we explore the moderate effect of different types of executive incentive on the relationship between R\&D investment and financially sustainable performance. Finally, 
the three-stage least square method (3SLS) of the simultaneous equation method (SEM) is employed in this paper. This can not only control the endogeneity of variables but also exclude the subjectivity of the choice of instrumental variables to make the empirical results more realistic and robust. The second part presents a literature review and the hypotheses, and the third part contains the methodology. The fourth part is the empirical results, and the final part is the conclusions and suggestions.

\section{Literature Review and Hypotheses}

\subsection{Relationship between RED Investment and Financially Sustainable Performance}

The direct target of innovation investment is to obtain profits, and enterprises introduce new production technology to improve financially performance and achieve excess returns. Most studies have shown that innovation investment has a significant positive effect on corporate performance. Stam and Wennberg [22] found that innovation investment improves the performance of start-up high-tech enterprises. Yunis et al. [23] found that there is a significant positive correlation between innovation investment and enterprise performance. However, some scholars argued that there is a non-significant positive relationship between innovation investment and corporate performance. Rosenbusch et al. [24] investigated the relationship between innovation investment and corporate performance in high-tech enterprises and found that there is a weak negative correlation between them. Hsu et al. [25] found that there is an inverted U-shaped relationship between innovation intensity and enterprise performance under the control of technical indicators. Naranjo-Valencia et al. [26] found that although there is a significant positive correlation between innovation investment and corporate performance, there is no significant relationship between the number of innovation personnel and corporate performance.

In terms of the lag effect of innovation investment, Ciftci and Cready [27] found that innovation investment is positively correlated with the company's future profit, and significantly positively correlated with the change in stock price lagging by one year, but not with the change in stock price in the current period. Falk [28] found that there is a significant positive correlation between innovation investment intensity and sales growth rate of lagging two periods, but this positive effect gradually decreases with time. Zabala et al. [29] explored the impact of innovation investment on financially sustainable performance from the perspective of property right heterogeneity. The results show that innovation investment has a positive impact on current period financial performance, and the positive correlation between innovation investment and lag financial performance gradually decreases.

Most of the existing literature measures financial performance directly by the indicators such as return on total assets and return on net assets, lacking distinction between short-term performance and long-term performance. The R\&D period of the energy industry is long [30], and the corporate profitability indicator is hard to reveal the effect of technological innovation in the short term. In the meantime, because the short-term financial performance is related to the performance assessment of the management, the management will choose less innovation investment to pursue corporate profits for their own interests driven by the psychology of risk aversion. Therefore, the short-term performance of innovation investment is difficult to improve rapidly, while the improvement in long-term performance and value of technological innovation could be more significant.

\subsection{The Impact of Executive Incentive on RED Investment and Financially Sustainable Performance}

According to the principal-agent theory, managers will not only pursue the goal of monetary income, but also obtain some non-monetary income. In a relatively perfect market environment, investors can establish a portfolio to avoid risks, while executives cannot disperse their human capital to obtain portfolio income, and only use operation performance in exchange for short-term returns such as compensation and benefits. Therefore, the management, especially the risk-averse management, will focuses on the projects that can improve the short-term performance, avoid the innovative $R \& D$ projects with high uncertainty, and adopts the appropriate incentive and constraint 
mechanism. For the executives, the key is to increase their innovation investment and improve the sustainable performance.

In terms of salary incentive, most scholars believed that salary incentive is positively related to financial performance, and it will strengthen the role of innovation investment in promoting sustainable performance. Coles et al. [31] found that salary incentive could effectively solve the principal-agent problem and enhance the motivation of management to engage in venture capital projects. Jacobsen and Andersen [32] found that salary incentives improve corporate performance significantly and positively moderate the relationship between innovation investment and corporate performance. However, some studies demonstrated that there is no significant positive correlation between salary incentive and corporate performance. Lui et al. [33] found that innovation investment has a significant positive effect on financial performance, and the positive moderate effect of equity incentive is excellent, but the moderate effect of salary incentive is poor. Lu et al. [34] found that there is an inverted U-shaped relationship between salary incentive and innovation investment.

In terms of equity incentive, Fong [35] believed that executive ownership can significantly increase the investment in innovation projects to improve the enterprise innovation level. The "interest alignment hypothesis" proposed by Jensen and Meckling [36] holds that with the increase in the proportion of executives' shareholding, the consistency of their own interests and corporate interests will also be improved. Therefore, equity incentives are conducive to reducing the first type of agency problem between shareholders and managers and urging executives to increase innovation investment to improve financial performance. Xu et al. [37] found that equity incentives can significantly moderate the positive correlation between innovation investment and financially sustainable performance. However, some scholars believed that the relationship between innovation investment and corporate performance is non-linear or even negative under the moderator of equity incentive. Alessandri and Pattit [38] found that salary incentives have a moderate negative effect on the relationship between innovation investment and financially sustainable performance, while equity incentives have a moderate positive effect. Zattoni and Minichilli [39] found that equity incentives do not improve financially sustainable performance. They argued that improving the corporate governance mechanism is an essential way to promote development of the equity incentive system. Polder and Veldhuizen [40] found that equity incentives are positively related to financial performance, but have an inverted U-shaped relationship with innovation investment.

The existing research has not formed a unified conclusion on the moderate mechanism of executive incentives between innovation investment and financially sustainable performance. The reasons could be as follows: first, the research objects are quite different, as some scholars select the whole industry enterprises as samples, while other studies take state-owned enterprises, private enterprises, high-tech enterprises as samples. Second, the application of executive incentive mechanisms in China is short, which may have a deviation on the impact of innovation investment and financial performance. Finally, there are gaps in the R\&D cycle and innovation risks in different industries, and the moderate effects of executive incentives are also different. Therefore, the research on the effect of executive incentive and innovation investment in the energy industry needs further analysis.

\subsection{Hypotheses}

Since Schumpeter [41] proposed the innovation theory, innovation performance has been a research hotspot. Innovation investment not only improves the core competitiveness of the enterprise, but also significantly improves the productivity of the enterprise [42]. Meanwhile, it brings new products or new technology to the enterprise, which makes the enterprise operate differently and beneficially to improve the market share of the enterprise. On the one hand, due to the long cycle and uncertainty of innovation and $R \& D$, especially in the field of advanced technology, the economic returns brought by innovation investment may lag many operation years [43], but in the long run, its cumulative effect will significantly promote the improvement in enterprise performance. On the other hand, based on the principal-agent theory and the management defense hypothesis, the decision-making 
behavior of management is subject to annual performance appraisal, while high-risk innovative projects may lead to higher R\&D expenditure. To pursue the improvement of financial performance during the term of office, management may limit the scale of R\&D expenditure, resulting in short-sighted behavior of self-interest, which is not conducive to the long-term development of enterprises. Therefore, this paper argues that there is an endogenous relationship between corporate innovation investment and sustainable financial performance.

As different industries have different forms of R\&D, the extent of performance improvement brought by innovation investment will be different. For technology-intensive energy enterprises, their development is based on technological innovation, which is the source of enterprise life, thus the input-output benefit of innovation is obvious; for capital-intensive energy enterprises, scale effect should be an important strategy for their development; and for labor-intensive energy enterprises, service mode change and management process innovation could bring more profits for enterprises. This leads to the phenomenon of some enterprises investing a lot in innovation while others do not have R\&D activities. Therefore, it is necessary to analyze the relationship between innovation investment and financial performance from the industry level. Based on the above analysis, this paper proposes the following hypotheses:

H1: Innovation investment has a positive effect on financially sustainable performance, and this effect is the most significant in technology-intensive energy enterprises.

H2: There is an interactive endogenous relationship between innovation investment and financially sustainable performance, and financially sustainable performance has a reverse effect on innovation investment, and the reverse effect is the most significant in technology-intensive energy enterprises.

From the perspective of the principal-agent theory, the management will adopt the egoism behavior that pays attention to the short-term economic benefit based on their own interest, and ignore or avoid the innovative RD investment that has risk uncertainty but is helpful to improve the sustainable operation ability of enterprises. Therefore, enterprises must implement some incentive policies to enhance the motivation of management to make innovative RD decisions, such as increasing short-term compensation returns or implementing equity incentive plans, so that their personal interests and the company's interests converge. Based on the above analysis, this paper proposes the following hypotheses:

H3: Salary incentives have a significantly positive moderating effect on the relationship between RD investment and financially sustainable performance.

H4: Equity incentives have a significantly positive moderating effect on the relationship between RD investment and financially sustainable performance.

\section{Proposed Methodologies}

\subsection{Energy Enterprises Background}

With the continuous development of the economy, the production factor density is widely used in the research field of enterprise classification. It was first proposed by Heckscher and Ohiln in H-O theory [44], which mainly refers to the degree of influence on production and management activities and the degree of dependence on various production input factors in the production process. The classification method of production factor intensity categorizes enterprises into three types, including technology-intensive, labor-intensive and capital-intensive enterprises. This classification could not only reveal the productivity and resource advantages of enterprises, but also reflect the changes in the proportion of production input factors brought about by technological progress.

Technology-intensive enterprises refer to enterprises with large investment in technical knowledge, high costs for RD, high cultural and technical level of workers, and high added-value of products, including, for example, renewable energy enterprises; capital-intensive enterprises refer to enterprises 
with large investment capital and great influence on production and operation activities, including, for example, electric power enterprises; labor-intensive industries refer to enterprises with large labor input and great influence on production and operation activities, including, for example, coal enterprises.

\subsection{Data Source}

Based on the CSMAR database, this paper collected data from the energy sector in the stock market. The executive incentive data and enterprise financial performance data were all from the CSMAR database; the RD investment data were obtained from the annual reports of each enterprise; some missing data of financial indicators were obtained through the sorting of the Tonghuashun database; and other relevant missing data were obtained from the WIND database and www.cninfo.com.cn. The statistical analysis was performed using Stata and Excel statistical software.

We used Ward linkage method in the cluster analysis to classify samples. According to the proportion of fixed assets, enterprises with a larger proportion of fixed assets belong to the capital-intensive companies, indicating that the capital is of higher importance. In terms of the RD expenditure-salary ratio, enterprises with higher ratios belong to the technology-intensive companies, indicating that the technological is of higher importance and others belong to the labor-intensive companies.

\subsection{Variables}

\subsubsection{Financially Sustainable Performance}

The existing literature focusses on financially sustainable performance from different perspectives and there is no unified conclusion based on measurement methods. Different measurement methods have their own advantages and disadvantages. Considering the data characteristics and the comprehensiveness of the evaluation indicators, we used the factor analysis method to measure financially sustainable performance. According to the article by Sher and Yang [45], this paper divided financially sustainable performance into two dimensions: short-term profitability and long-term development capacity.

- $\quad$ Short-term profitability (STP). Profitability refers to the ability of a company to make a profit. The fundamental goal of a company's survival is to obtain profits. The acquisition of profits is the guarantee of the realization of investors' interests and the basis for the sustainable growth of companies [46]. If the company has a lower profitability, and even suffers from continuous losses, the survival of the company will be threatened. The high-quality profitability is the basis for the company to maintain its sustainable growth. In this paper, the measurement of profitability is mainly based on some financial performance indicators, namely total return on assets (ROA), return on net assets (ROE), and operating profit margin (OPM).

- $\quad$ Long-term development capacity (LTD). The existing literature has argued that managers are concerned about the improvement of business performance [47-49], while investors are more inclined to realize the long-term profit [50]. Therefore, this paper selects three indicators, including net profit growth rate (NPGR), earnings per share growth rate (EPS), and total asset growth rate (TAGR), as the measurement indicators of the company's long-term development capacity.

First, we performed $\mathrm{KMO}$ and Bartlett tests on the sample data. The results show that the value of $\mathrm{KMO}$ is 0.695 , which is greater than 0.5 , indicating that the factor analysis method is appropriate. The Bartlett test has a $p$ value of 0.000 , which also indicates that the sample data are valid for factor analysis. Second, we extracted the common factor and performed dimension reduction of the principal components. The results are shown in Table 1 . The cumulative contribution rate of the two principal component factors reached $90.119 \%$, indicating that the indicator system retains most information of original variables. Finally, we established a load matrix for the two principal components factors. 
The results are shown in Table 2. Then we built the following comprehensive indicators of short-term profitability and long-term development capacity.

$$
\begin{gathered}
S T P=(0.893 R O A+0.842 R O E+0.851 O P M) / 3 \\
L T D=(0.961 E P S+0.907 N P G R+0.912 T A G R) / 3
\end{gathered}
$$

Table 1. Total variance explained.

\begin{tabular}{cccc}
\hline \multirow{2}{*}{ Component } & \multicolumn{3}{c}{ Rotation Sums of Squared Loadings } \\
\cline { 2 - 4 } & Total & \% of Variance & Cumulative \% \\
\hline 1 & 3.162 & 56.102 & 56.102 \\
2 & 2.934 & 34.017 & 90.119 \\
\hline
\end{tabular}

Table 2. Rotated component matrix.

\begin{tabular}{ccc}
\hline \multirow{2}{*}{ Factors } & \multicolumn{2}{c}{ Component } \\
\cline { 2 - 3 } & $\mathbf{1}$ & $\mathbf{2}$ \\
\hline EPS & 0.037 & 0.961 \\
NPGR & 0.015 & 0.907 \\
TAGR & 0.012 & 0.912 \\
ROA & 0.893 & 0.057 \\
ROE & 0.842 & 0.059 \\
OPM & 0.851 & -0.019 \\
\hline
\end{tabular}

\subsubsection{RD Investment}

The RD investment includes a series of investments such as scientific and technological talents, RD funds, and mechanical equipment. We follow Cumming et al. [51] and used the proportion of RD expenditure in operating revenue to represent RD investment.

\subsubsection{Executive Incentives}

This paper defined enterprise executives as all supervisors, directors, managers, presidents, and board secretaries [37]. The long-term equity incentives (EI) are represented by the sum ratio of executives' shareholdings (in millions RMB). The short-term salary incentives (SI) are represented by the total annual salary of executives.

\subsubsection{Control Variables (C)}

This paper mainly considered the following variables: the company size (Size), leverage ratio (Lev), ownership concentration (Own), the nature of ownership (State), the proportion of independent directors (Indep), board size (BS), industrial (Industry) and annual (Year) fixed effect [52-54].

\subsection{Modeling}

This paper used the simultaneous equations method to test the relationship between RD investment and financially sustainable performance and performs 3SLS to build Models (3)-(6).

$$
\begin{aligned}
& R D_{i, t}=a_{0}+a_{1} S T P_{i, t}+a_{2} S T P_{i, t-1}+a_{3} S T P_{i, t-2}+\theta_{l} \sum_{i=1}^{i=l} C_{i, t}+\mu_{i, t} \\
& R D_{i, t}=a_{0}+a_{1} L T D_{i, t}+a_{2} L T D_{i, t-1}+a_{3} L T D_{i, t-2}+\theta_{l} \sum_{i=1}^{i=l} C_{i, t}+\mu_{i, t} \\
& S T P_{i, t}=\beta_{0}+\beta_{1} R D_{i, t}+\beta_{2} R D_{i, t-1}+\beta_{3} R D_{i, t-2}+\theta_{m} \sum_{i=1}^{i=m} C_{i, t}+\varepsilon_{i, t}
\end{aligned}
$$




$$
L T D_{i, t}=\beta_{0}+\beta_{1} R D_{i, t}+\beta_{2} R D_{i, t-1}+\beta_{3} R D_{i, t-2}+\theta_{m} \sum_{i=1}^{i=m} C_{i, t}+\varepsilon_{i, t}
$$

To examine the impact of executive incentive on the relationship between RD investment and financially sustainable performance and avoid the endogenous interaction between RD investment and financially sustainable performance, we used the dependent variable of the lag period and the interaction term between RD investment and executive incentive to explore the impact of executive incentive. Then, Models (7) and (8) were created as follows.

$$
\begin{gathered}
S T P_{i, t}=\gamma_{0}+\gamma_{1} R D_{i, t-1}+\gamma_{2} R D_{i, t-2}+\gamma_{3} S I_{i, t-1}+\gamma_{4} E I_{i, t-1}+\gamma_{5} I N I_{i, t-1} \\
* S I_{i, t-1}+\gamma_{6} R D_{i, t-1} * E I_{i, t-1}+\theta_{n} \sum_{i=1}^{i=n} C_{i, t}+\varphi_{i, t} \\
L T D_{i, t}=\gamma_{0}+\gamma_{1} R D_{i, t-1}+\gamma_{2} R D_{i, t-2}+\gamma_{3} S I_{i, t-1}+\gamma_{4} E I_{i, t-1}+\gamma_{5} R D_{i, t-1} \\
* S I_{i, t-1}+\gamma_{6} R D_{i, t-1} * E I_{i, t-1}+\theta_{n} \sum_{i=1}^{i=n} C_{i, t}+\varphi_{i, t}
\end{gathered}
$$

\section{Results, Nalyses and Discussion}

\subsection{Descriptive and Correlation Analysis}

The descriptive analysis results are shown in Table 3. To eliminate the influence of extreme values, this paper uses the Winsorize method to deal with continuous variables according to $1 \%$ and $99 \%$. The results in Table 3 demonstrate that the mean of RD investment is 0.031 , indicating that the RD investment of enterprises is insufficient. The mean of salary incentives is 6.14 million RMB, but the difference between the minimum value and the maximum value is large, which shows that there is a significant difference in executive incentives. The mean of equity incentive is 0.105 , but there are also extreme cases in which managers have no shares or executives hold more than 0.721 shares. Therefore, Chinese energy enterprises have implemented different equity incentives.

Table 3. Descriptive analysis.

\begin{tabular}{ccccc}
\hline Variables & Mean & Std. & Min. & Max. \\
\hline STP & 0.124 & 0.085 & -0.639 & 1.145 \\
LTD & 0.261 & 0.552 & -0.874 & 3.814 \\
RD & 0.031 & 0.035 & 0.001 & 0.195 \\
SI & 6.14 & 7.415 & 0.601 & 32.457 \\
EI & 0.105 & 0.251 & 0.000 & 0.721 \\
Size & 21.817 & 1.441 & 17.632 & 24.502 \\
Lev & 0.541 & 0.198 & 0.095 & 0.915 \\
Own & 0.351 & 0.154 & 0.025 & 0.751 \\
State & 0.623 & 0.474 & 0.000 & 1.000 \\
Indep. & 0.359 & 0.055 & 0.094 & 0.805 \\
BS & 2.251 & 0.233 & 1.421 & 2.941 \\
\hline
\end{tabular}

The correlation analysis results are shown in Table 4. The Spearman correlation coefficient between RD investment and financially sustainable performance (STP, LTD) is significantly positive at the levels of $1 \%$ and $5 \%$, respectively, while Pearson correlation coefficient is not significantly negative, which indicates that RD investment and financially sustainable performance may not be a one-way relationship, and their relationship needs further study. In terms of executive incentives, salary incentives and equity incentives are positively related to short-term profitability and long-term development capacity, which shows that executive incentives are conducive to the improvement of financially sustainable performance. In addition, there is no significant correlation between salary incentives and equity incentives, which helps to examine the role of the two in Models (7) and (8). The other correlation coefficients in Table 4 are small, indicating that there is no multicollinearity between variables. 
Table 4. Spearman and Pearson correlation analysis.

\begin{tabular}{cccccccccc}
\hline Variables & STP & LTD & RD & SI & EI & Own & State & Indep. & BS \\
\hline STP & 1 & $0.281^{* *}$ & $0.171^{* *}$ & $0.352^{* * *}$ & $0.253^{* * *}$ & $0.069^{* *}$ & $-0.254^{* *}$ & $-0.064^{* *}$ & -0.015 \\
LTD & $0.321^{*}$ & 1 & $0.143^{* * *}$ & $0.315^{* * *}$ & $0.103^{* *}$ & $0.072^{* *}$ & $-0.175^{* *}$ & $-0.075^{* *}$ & $-0.038^{* *}$ \\
RD & -0.007 & -0.015 & 1 & $0.061^{* *}$ & $0.95^{* * *}$ & $-0.103^{* *}$ & $-0.148^{* *}$ & 0.003 & $-0.077^{* * *}$ \\
SI & $0.197^{* * *}$ & $0.088^{*}$ & $0.035^{* * *}$ & 1 & 0.081 & $0.064^{* *}$ & 0.015 & -0.025 & $0.225^{* * *}$ \\
EI & $0.087^{*}$ & $0.095^{* * *}$ & $0.009^{*}$ & -0.038 & 1 & $-0.105^{* *}$ & $-0.227^{* *}$ & $0.037^{*}$ & $-0.037^{*}$ \\
Own & $0.077^{* * *}$ & $0.125^{*}$ & $-0.062^{* *}$ & $0.041^{*}$ & -0.013 & 1 & $0.284^{* *}$ & $0.019^{* * *}$ & $0.038^{* * *}$ \\
State & $-0.127^{* * *}$ & $-0.081^{* *}$ & $-0.076^{* *}$ & $-00.51^{* *}$ & $-0.415^{* * *}$ & $0.351^{* *}$ & 1 & 0.018 & $0.161^{* * *}$ \\
Indep. & $-0.067^{* *}$ & $-0.215^{* *}$ & 0.015 & $0.043^{* *}$ & 0.027 & 0.035 & 0.035 & 1 & 0.035 \\
BS & 0.013 & 0.027 & $-0.041^{* *}$ & $0.271^{* *}$ & $-0.051^{*}$ & $0.059^{* *}$ & $0.171^{* *}$ & $-0.391^{* *}$ & 1 \\
\hline Note: & The upper and lower triangle are Spearman and Pearson correlation coefficient, respectively; \\
***,**,* Significant at $1 \%, 5 \%$, and 10\% levels, respectively.
\end{tabular}

\subsection{Endogenous Test}

The above analysis shows that executives could improve the current period performance through reducing RD innovation expenditure. However, the increase in RD investment will inevitably enhance the market competitiveness of energy enterprises, thus improving the financially sustainable performance. Therefore, there may be an endogenous relationship between RD investment and financially sustainable performance, which leads to the endogenous deviation in the results of the ordinary least square method. Therefore, this paper first tests the endogeneity of these two variables. We employed the Hausmann endogeneity test, and the results are shown in Table 5. $\varepsilon_{1}$ and $\varepsilon_{2}$ are the residuals obtained by linear regression of all exogenous variables with RD investment in Equations (3) and (4), respectively. Then this paper introduces them into Equations (5) and (6), respectively. The regression coefficients are -2.808 and -2.359 , respectively. The coefficients significance shows that there is an endogenous relationship between RD investment, short-term profitability and long-term development capacity. Therefore, we need to use simultaneous equation model to estimate the relationship between RD investment and financially sustainable performance.

Table 5. The results of the Hausman test.

\begin{tabular}{cccc}
\hline Item & Coefficient & $p$ Value & Adj- $^{2}$ \\
\hline$\varepsilon_{1}$ & -2.808 & 0.000 & 0.225 \\
$\varepsilon_{2}$ & -2.359 & 0.000 & 0.248 \\
\hline
\end{tabular}

\subsection{Regression Analysis of Full Samples}

The full sample regression results in Table 6 show that, from the perspective of the relationship between RD investment and financially sustainable performance, the results of 3SLS estimation are partially opposite to those of ordinary least square (OLS) estimation, because OLS estimation does not solve the endogenous problem. The 3SLS estimation could effectively solves the endogenous problem of RD investment and financially sustainable performance. In the aspect of RD investment affecting financially sustainable performance, the results show that the current period's RD investment has a significant negative impact on short-term profitability and long-term development capacity, which means that the increase in RD expenditure in the current period will reduce profits. Meanwhile, $\mathrm{RD}$ investment in lag period I and II has a positive impact on the current period's financially sustainable performance, but the coefficient is not significant. The reason could be that different types of RD project produce actual economic benefits at different times. 
Table 6. The results of three-stage least square (3SLS) and ordinary least square (OLS) regression based on the full sample.

\begin{tabular}{|c|c|c|c|c|c|c|c|c|}
\hline \multirow[b]{2}{*}{ Equation } & \multicolumn{4}{|c|}{ 3SLS Estimation } & \multicolumn{4}{|c|}{ OLS Estimation } \\
\hline & (3) & (4) & (5) & (6) & (3) & (4) & (5) & (6) \\
\hline Variables & $\mathrm{RD}$ & $\mathrm{RD}$ & STP & LTD & $\mathrm{RD}$ & RD & STP & LTD \\
\hline $\mathrm{STP}_{\mathrm{t}}$ & $\begin{array}{c}0.401{ }^{* *} \\
(2.43)\end{array}$ & & & & $\begin{array}{l}-0.054^{* * *} \\
(-3.43)\end{array}$ & & & \\
\hline $\mathrm{STP}_{\mathrm{t}-1}$ & $\begin{array}{c}-0.559 * * * \\
(-5.07)\end{array}$ & & & & $\begin{array}{c}0.055^{* * *} \\
(2.65)\end{array}$ & & & \\
\hline $\mathrm{STP}_{\mathrm{t}-2}$ & $\begin{array}{c}-0.122 * * * \\
(-2.59)\end{array}$ & & & & $\begin{array}{l}-0.018 \\
(-0.97)\end{array}$ & & & \\
\hline LTD $_{t}$ & & $\begin{array}{c}0.851 * \\
(2.86)\end{array}$ & & & & $\begin{array}{c}-0.077^{* * *} \\
(-4.34)\end{array}$ & & \\
\hline $\operatorname{LTD}_{\mathrm{t}-1}$ & & $\begin{array}{c}-0.423 \text { ** } \\
(-6.51)\end{array}$ & & & & $\begin{array}{c}0.088^{* * *} \\
(3.34)\end{array}$ & & \\
\hline $\mathrm{LTD}_{\mathrm{t}-2}$ & & $\begin{array}{c}-0.357^{* * * *} \\
(-2.65)\end{array}$ & & & & $\begin{array}{l}-0.127 \\
(-2.34)\end{array}$ & & \\
\hline $\mathrm{RD}_{\mathrm{t}}$ & & & $\begin{array}{c}-1.275 * * * \\
(-2.85)\end{array}$ & $\begin{array}{c}-1.605 \text { ** } \\
(-4.51)\end{array}$ & & & $\begin{array}{l}-0.132 \\
(-1.19)\end{array}$ & $\begin{array}{l}-0.325 \\
(-2.35)\end{array}$ \\
\hline $\mathrm{RD}_{\mathrm{t}-1}$ & & & $\begin{array}{l}0.243 \\
(0.95)\end{array}$ & $\begin{array}{l}0.354 \\
(1.25)\end{array}$ & & & $\begin{array}{l}-0.094 \\
-0.65)\end{array}$ & $\begin{array}{l}-0.116 \\
(-1.54)\end{array}$ \\
\hline$R D_{t-2}$ & & & $\begin{array}{l}0.087 \\
(0.63)\end{array}$ & $\begin{array}{l}0.151 \\
(0.89)\end{array}$ & & & $\begin{array}{l}0.087 \\
(0.85)\end{array}$ & $\begin{array}{l}0.145 \\
(3.23)\end{array}$ \\
\hline _Cons & $\begin{array}{l}0.802 \\
(0.35)\end{array}$ & $\begin{array}{l}0.205 \\
(0.39)\end{array}$ & $\begin{array}{l}-0.035 \\
(-0.51)\end{array}$ & $\begin{array}{l}-0.157 \\
(-0.45)\end{array}$ & $\begin{array}{l}-0.051 \\
(-0.34)\end{array}$ & $\begin{array}{l}-0.203 \\
(-0.74)\end{array}$ & $\begin{array}{c}-0.327^{* *} \\
(-7.24)\end{array}$ & $\begin{array}{c}-0.536 \text { ** } \\
(-9.28)\end{array}$ \\
\hline Controls & Yes & Yes & Yes & Yes & Yes & Yes & Yes & Yes \\
\hline $\begin{array}{l}\text { Year and Industry } \\
\text { Fixed Effects }\end{array}$ & - & - & - & - & Yes & Yes & Yes & Yes \\
\hline $\mathrm{N}$ & 1520 & 1520 & 1520 & 1520 & 1520 & 1520 & 1520 & 1520 \\
\hline $\mathrm{R}^{2}$ & 0.343 & 0.359 & 0.466 & 0.472 & 0.457 & 0.455 & 0.445 & 0.447 \\
\hline Adj. $R^{2}$ & - & - & - & - & 0.431 & 0.427 & 0.419 & 0.424 \\
\hline
\end{tabular}

Note: ${ }^{* * *}, * *,{ }^{*}$ Significant at $1 \%, 5 \%$, and $10 \%$ levels, respectively; () of 3SLS estimation and () of OLS estimation represent $\mathrm{z}$ value and $\mathrm{t}$ value, respectively.

In the aspect of financially sustainable performance reverse affecting RD investment, the short-term profitability and long-term development capacity of the current period are positively correlated with RD investment, while the lag period I and II of short-term profitability and long-term development capacity are negatively correlated with RD investment. This shows that RD investment decision-making has a time lag. In the case of better financially sustainable performance in the current period, the company lacks motivation for future RD innovation. On the contrary, poor financially sustainable performance in the current period will promote RD investment. At this stage, we believe that financially sustainable performance lags behind RD investment, so it is less likely that financially sustainable performance will reverse affect RD investment. Therefore, this is only a measurement result and has no practical significance.

\subsection{Regression Analysis of Different Type Energy Companies}

The results of 3SLS estimation for different types of energy companies are shown in Table 7. For technology-intensive energy companies, the short-term profitability and long-term development capacity of lag period I and II are significantly negative correlated with RD investment. The RD investment in lag period I and II has a positive impact on the short-term profitability and long-term development capacity. The coefficient of lag period I is significant at the level of $1 \%$, and has a significant negative correlation with the short-term profitability and long-term development capacity of the current period. This means that the economic benefits of RD investment have an obvious lag effect, which is consistent with the characteristics of technology-intensive energy companies. In addition, the current $\mathrm{RD}$ investment has a negative impact on the financially sustainable performance. 
Table 7. The results of 3SLS regression based on industry.

\begin{tabular}{|c|c|c|c|c|c|c|c|c|c|c|c|c|}
\hline \multirow{2}{*}{$\begin{array}{l}\text { Industry } \\
\text { Equation }\end{array}$} & \multicolumn{4}{|c|}{ Technology } & \multicolumn{4}{|c|}{ Capital } & \multicolumn{4}{|c|}{ Labor } \\
\hline & (3) & (4) & (5) & (6) & (3) & (4) & (5) & (6) & (3) & (4) & (5) & (6) \\
\hline Variables & $\mathrm{RD}$ & RD & STP & LTD & $\mathrm{RD}$ & RD & STP & LTD & $\mathrm{RD}$ & RD & STP & LTD \\
\hline $\mathrm{STP}_{\mathrm{t}}$ & $\begin{array}{c}1.417^{* * * *} \\
(3.81)\end{array}$ & & & & $\begin{array}{c}-0.247^{* * *} \\
(-2.86)\end{array}$ & & & & $\begin{array}{c}-0.325 \text { *** } \\
(-4.17)\end{array}$ & & & \\
\hline $\mathrm{STP}_{\mathrm{t}-1}$ & $\begin{array}{c}-0.445 * * \\
(-2.25)\end{array}$ & & & & $\begin{array}{c}0.145^{* * *} \\
(3.49)\end{array}$ & & & & $\begin{array}{c}0.421^{* *} \\
(1.28)\end{array}$ & & & \\
\hline $\mathrm{STP}_{\mathrm{t}-2}$ & $\begin{array}{c}-0.559 * * * * \\
(-4.91)\end{array}$ & & & & $\begin{array}{l}-0.035 \\
(-1.71)\end{array}$ & & & & $\begin{array}{l}-0.031 \\
(-0.35)\end{array}$ & & & \\
\hline $\mathrm{LTD}_{\mathrm{t}}$ & & $\begin{array}{c}0.1384^{* *} \\
(3.94)\end{array}$ & & & & $\begin{array}{c}-0.255 \text { ** } \\
(-3.17)\end{array}$ & & & & $\begin{array}{c}-0.401 * * \\
(-5.51)\end{array}$ & & \\
\hline $\operatorname{LTD}_{\mathrm{t}-1}$ & & $\begin{array}{c}-0.543 \text { ** } \\
(-6.92)\end{array}$ & & & & $\begin{array}{c}0.135 \text { ** } \\
(3.16)\end{array}$ & & & & $\begin{array}{c}0.243 \text { ** } \\
(2.51)\end{array}$ & & \\
\hline $\operatorname{LTD}_{\mathrm{t}-2}$ & & $\begin{array}{c}-0.635 \text { ** } \\
(-5.48)\end{array}$ & & & & $\begin{array}{l}-0.015 \\
(-1.16)\end{array}$ & & & & $\begin{array}{l}-0.024 \\
(-0.05)\end{array}$ & & \\
\hline $\mathrm{RD}_{\mathrm{t}}$ & & & $\begin{array}{c}-0.323 \text { ** } \\
(-2.85)\end{array}$ & $\begin{array}{c}-0.441^{* * *} \\
(-5.25)\end{array}$ & & & $\begin{array}{c}10.914 \text { ** } \\
(3.42)\end{array}$ & $\begin{array}{c}4.151 \text { *** } \\
(1.73)\end{array}$ & & & $\begin{array}{l}0.354 \\
(0.35)\end{array}$ & $\begin{array}{l}0.404 \\
(0.59)\end{array}$ \\
\hline$R D_{t-1}$ & & & $\begin{array}{c}0.197^{* * * *} \\
(2.79)\end{array}$ & $\begin{array}{c}0.235^{* * *} \\
(3.57)\end{array}$ & & & $\begin{array}{c}-8.013 \text { ** } \\
(-2.81)\end{array}$ & $\begin{array}{c}-5.509 \text { ** } \\
(-2.15)\end{array}$ & & & $\begin{array}{l}-1.141 \\
(-1.24)\end{array}$ & $\begin{array}{l}-1.245 \\
(-2.05)\end{array}$ \\
\hline$R D_{t-2}$ & & & $\begin{array}{c}0.085 * \\
(1.75)\end{array}$ & $\begin{array}{c}0.115^{*} \\
(2.36)\end{array}$ & & & $\begin{array}{c}-5.124 * * \\
(-2.62)\end{array}$ & $\begin{array}{c}-4.619 * * \\
(-3.65)\end{array}$ & & & $\begin{array}{l}0.367 \\
(0.72)\end{array}$ & $\begin{array}{l}0.465 \\
(1.35)\end{array}$ \\
\hline _Cons & $\begin{array}{l}-0.149 \\
(-0.36)\end{array}$ & $\begin{array}{l}-0.045 \\
(-0.39)\end{array}$ & $\begin{array}{l}-0.027 \\
(-0.54)\end{array}$ & $\begin{array}{l}-0.029 \\
(-0.65)\end{array}$ & $\begin{array}{l}0.015 \\
(0.08)\end{array}$ & $\begin{array}{l}0.015 \\
(0.16)\end{array}$ & $\begin{array}{c}-0.941 \text { * } \\
(-2.53)\end{array}$ & $\begin{array}{c}-0.345^{*} \\
(-4.17)\end{array}$ & $\begin{array}{c}-0.512 * * \\
(-3.05)\end{array}$ & $\begin{array}{c}-0.135 * \\
(-4.25)\end{array}$ & $\begin{array}{l}-0.159 \\
(-1.24)\end{array}$ & $\begin{array}{l}-0.175 \\
(-2.23)\end{array}$ \\
\hline Controls & Yes & Yes & Yes & Yes & Yes & Yes & Yes & Yes & Yes & Yes & Yes & Yes \\
\hline $\mathrm{N}$ & 630 & 630 & 630 & 630 & 380 & 380 & 380 & 380 & 510 & 510 & 510 & 510 \\
\hline $\mathrm{R}^{2}$ & 0.278 & 0.275 & 0.359 & 0.351 & 0.277 & 0.279 & 0.355 & 0.346 & 0.439 & 0.447 & 0.242 & 0.235 \\
\hline
\end{tabular}

For the capital-intensive energy companies, the result is quite different from that of technology-intensive energy companies. The short-term profitability and long-term development capacity of lag period I are significantly positively correlated with the current period's RD investment. $\mathrm{RD}$ investment in the current period has a significant positive impact on short-term profitability and long-term development capacity. The input is proportional to the output, which is also in line with the characteristics of capital-intensive energy company. However, the RD investment in the lag periods I and II significant restrains the short-term profitability and long-term development capacity of the current period, which may be due to the increase in the depreciation and amortization ratio brought by the RD investment in the previous period, thus reducing the enterprise's revenue.

For labor-intensive energy companies, the short-term profitability and long-term development capacity of lag period I have a significant positive correlation with RD investment at the level of $10 \%$, which is similar to capital-intensive energy companies. Only with better financially sustainable performance in the previous stage can energy companies invest their profits in future RD. There is no significant correlation between RD investment and short-term profitability and long-term development capacity, which could be related to low RD investment and innovation efficiency of labor-intensive energy companies.

\subsection{The Moderating Effect of Executive Incentives}

RD investment and executive incentives in the lag period are used as independent variables and introduced into Equations (7) and (8). The results are shown in Table 8. In the context of the full sample, the RD investment in the lag period has a positive effect on short-term profitability, and the impact in the lag period I is significant, which is consistent with the previous results. After the introduction of the interaction between the lag period executive incentives and RD investment, it is found that salary incentives could significantly improve the short-term profitability and long-term development capacity, and the interaction term coefficient with RD investment is also significantly positive, which means that salary incentives can promote the increase in the previous period's RD investment. It has a positive moderate effect on the relationship between RD investment and financially sustainable performance. 
Table 8. The moderating effect of executive incentive based on industry.

\begin{tabular}{|c|c|c|c|c|c|c|c|c|}
\hline \multirow{3}{*}{$\begin{array}{l}\text { Industry } \\
\text { Equation } \\
\text { Variables }\end{array}$} & \multicolumn{2}{|c|}{ Full Sample } & \multicolumn{2}{|c|}{ Technology } & \multicolumn{2}{|c|}{ Capital } & \multicolumn{2}{|c|}{ Labor } \\
\hline & (7) & (8) & (7) & (8) & (7) & (8) & (7) & (8) \\
\hline & STP & LTD & STP & LTD & STP & LTD & STP & LTD \\
\hline$R D_{t-1}$ & $\begin{array}{c}0.087^{*} \\
(1.71)\end{array}$ & $\begin{array}{l}0.085^{*} \\
(2.52)\end{array}$ & $\begin{array}{c}0.076^{* *} \\
(2.37)\end{array}$ & $\begin{array}{c}0.081^{* *} \\
(2.53)\end{array}$ & $\begin{array}{l}-0.285 \\
(-0.56)\end{array}$ & $\begin{array}{l}-0.403 \\
(-0.65)\end{array}$ & $\begin{array}{l}-0.874^{*} \\
(-2.17)\end{array}$ & $\begin{array}{l}-0.805^{*} \\
(-2.35)\end{array}$ \\
\hline$R D_{t-2}$ & $\begin{array}{l}0.065 \\
(1.45)\end{array}$ & $\begin{array}{l}0.047 \\
(0.72)\end{array}$ & $\begin{array}{c}0.162^{* *} \\
(2.51)\end{array}$ & $\begin{array}{c}0.225^{* *} \\
(4.36)\end{array}$ & $\begin{array}{l}-0.138 \\
(-0.27)\end{array}$ & $\begin{array}{l}-0.131 \\
(-0.27)\end{array}$ & $\begin{array}{l}0.068 \\
(0.15)\end{array}$ & $\begin{array}{l}0.091 \\
(0.28)\end{array}$ \\
\hline $\mathrm{SI}_{\mathrm{t}-1}$ & $\begin{array}{c}0.135^{* * *} \\
(3.81)\end{array}$ & $\begin{array}{c}0.614^{* *} \\
(6.41)\end{array}$ & $\begin{array}{c}0.118^{*} \\
(1.85)\end{array}$ & $\begin{array}{c}0.157^{*} \\
(1.41)\end{array}$ & $\begin{array}{l}0.057^{*} \\
(0.75)\end{array}$ & $\begin{array}{l}0.078^{*} \\
(0.88)\end{array}$ & $\begin{array}{l}0.017 \\
(0.24)\end{array}$ & $\begin{array}{l}0.054 \\
(0.59)\end{array}$ \\
\hline $\mathrm{EI}_{\mathrm{t}-1}$ & $\begin{array}{l}-0.061 \\
(-0.81)\end{array}$ & $\begin{array}{l}-0.085 \\
(-2.45)\end{array}$ & $\begin{array}{l}0.016 \\
(0.29)\end{array}$ & $\begin{array}{l}0.082 \\
(0.51)\end{array}$ & $\begin{array}{l}-0.028 \\
(-0.14)\end{array}$ & $\begin{array}{l}-0.015 \\
(-0.07)\end{array}$ & $\begin{array}{l}-0.085 \\
(-1.26)\end{array}$ & $\begin{array}{l}-0.046 \\
(-1.41)\end{array}$ \\
\hline $\mathrm{RD}_{\mathrm{t}-1} * \mathrm{SI}_{\mathrm{t}-1}$ & $\begin{array}{l}1.704 * \\
(1.71)\end{array}$ & $\begin{array}{c}1.857^{* *} \\
(2.85)\end{array}$ & $\begin{array}{c}2.512 * * \\
(2.67)\end{array}$ & $\begin{array}{c}2.241 * * \\
(2.46)\end{array}$ & $\begin{array}{l}1.573^{* * *} \\
(2.27)\end{array}$ & $\begin{array}{c}1.331 \text { ** } \\
(4.24)\end{array}$ & $\begin{array}{c}1.831^{* * *} \\
(3.14)\end{array}$ & $\begin{array}{c}1.803^{* *} \\
(2.51)\end{array}$ \\
\hline $\mathrm{RD}_{\mathrm{t}-1} * \mathrm{EI}_{\mathrm{t}-1}$ & $\begin{array}{l}2.253 \\
(1.82)\end{array}$ & $\begin{array}{l}1.385 \\
(1.45)\end{array}$ & $\begin{array}{l}0.853 \\
(0.35)\end{array}$ & $\begin{array}{l}0.827 \\
(0.54)\end{array}$ & $\begin{array}{l}0.825 \\
(0.19)\end{array}$ & $\begin{array}{l}0.816 \\
(0.17)\end{array}$ & $\begin{array}{c}6.143^{* *} \\
(2.18)\end{array}$ & $\begin{array}{c}5.046^{* * *} \\
(2.51)\end{array}$ \\
\hline _Cons & $\begin{array}{c}-0.095 * * \\
(-1.94)\end{array}$ & $\begin{array}{c}-0.547^{*} \\
(-6.58)\end{array}$ & $\begin{array}{l}-0.048 \\
(-0.57)\end{array}$ & $\begin{array}{l}-0.064 \\
(-0.63)\end{array}$ & $\begin{array}{c}-0.288^{* *} \\
(-2.34)\end{array}$ & $\begin{array}{c}-0.245 * \\
(-2.25)\end{array}$ & $\begin{array}{c}-0.159 * \\
(-1.65)\end{array}$ & $\begin{array}{l}-0.251 \\
(-1.74)\end{array}$ \\
\hline Controls & Yes & Yes & Yes & Yes & Yes & Yes & Yes & Yes \\
\hline $\begin{array}{l}\text { Year and Industry } \\
\text { Fixed Effects }\end{array}$ & Yes & Yes & Yes & Yes & Yes & Yes & Yes & Yes \\
\hline N & 1520 & 1520 & 630 & 630 & 380 & 380 & 510 & 510 \\
\hline $\mathrm{R}^{2}$ & 0.379 & 0.378 & 0.445 & 0.447 & 0.469 & 0.452 & 0.415 & 0.413 \\
\hline Adj. $R^{2}$ & 0.332 & 0.335 & 0.427 & 0.392 & 0.392 & 0.384 & 0.338 & 0.345 \\
\hline
\end{tabular}

Note: ${ }^{* * *}, * *,{ }^{*}$ Significant at $1 \%, 5 \%$, and $10 \%$ levels, respectively; () of OLS estimation represents $t$ value.

In the context of the enterprise level sample, the technology-intensive energy companies further verify the role of salary incentives. However, for the capital-intensive energy companies and labor-intensive energy companies, although the lag period RD investment may inhibit the current period's financially sustainable performance due to depreciation and amortization, the salary incentive still plays a catalytic role, which can significantly moderate the positive impact of RD investment on short-term profitability and long-term development capacity. However, for equity incentive, no matter the full sample or the enterprise level sample, RD investment has no significant impact on short-term profitability and long-term development capacity.

\section{Conclusions and Policy Implications}

The results demonstrate that the previous period's sustainable financial performance has a significant negative impact on the current period RD investment. Meanwhile, the current period's RD investment has a significant negative impact on the current period's financially sustainable performance, while the previous period's RD investment has a positive impact on the current period's financially sustainable performance with no significant level. In the context of different types of energy company, for technology-intensive energy companies, the previous period's financially sustainable performance has a significant negative impact on the current period RD investment. For capital-intensive energy companies, the result is the opposite compared to technology-intensive energy companies. The financially sustainable performance in the previous period is positively correlated with the RD investment in the current period, and the RD investment in the current period is significantly positively correlated with the financially sustainable performance in the current period. However, the previous RD investment has a significant negative impact on the current period financially sustainable performance. For labor-intensive energy companies, the impact of financially sustainable performance on RD investment is similar to that of capital-intensive energy companies, while the positive effect of RD investment on financially sustainable performance is not significant.

In the moderate effect of executive incentives, salary incentives could significantly improve financially sustainable performance, and has a moderate positive effect on RD investment and on financially sustainable performance. In the context of different types of companies, 
for technology-intensive energy companies, salary incentives can improve the executive motivation of RD investment and enhance the future profitability of the company. For capital-intensive energy companies and labor-intensive energy companies, although the previous period's RD investment may have a negative impact on the current period's financially sustainable performance, the increase in executive incentives is conducive to the smooth operation of energy companies and the improvement of financially sustainable performance. Therefore, this paper believes that salary incentives have a significant positive moderate effect on the relationship between RD investment and financially sustainable performance. In contrast, equity incentives are not significant in the regression results of the full sample, which means that equity incentives have no significant moderate effect on the relationship between RD investment and financially sustainable performance.

The implications of this paper are as follows: first, energy enterprises should improve their incentive mechanisms for executives—on the one hand, improving the level of salary incentives could stimulate managers' motivation to serve the company, and on the other hand, improving the level of equity incentives can reduce the conflict of interests between managers and shareholders and improve energy enterprise's financially sustainable performance by reducing the managers' short-sighted behavior and the cost of principal-agent problems. Second, energy companies should enhance their awareness of technological innovation and increase RD investment. In the increasingly fierce market competition, although technological innovation activities are uncertain and high-risk, most scholars believe that RD investment can bring sustainable growth to enterprises. Innovation-oriented energy enterprises have greater potential for sustainable growth and increase investment in RD activities. Therefore, technology-intensive energy enterprises rely on more innovation activities than non-technology-intensive energy enterprises, and they should pay more attention to RD investment than that of general energy enterprises. Finally, energy companies should attach importance to the combination of executive incentives and RD investment. The results indicate that the impact of $\mathrm{RD}$ investment on financially sustainable performance will be moderated by executive incentives. According to the theory of competitive advantage, the resources owned by an enterprise are the source of its own advantages. The effective utilization of resources can be transformed into unparalleled competitive advantage.

This paper uses short-term profitability and long-term development capacity to measure financially sustainable performance. However, future research could use different methods, such as the sustainable growth model proposed by Colley et al. [55], to measure financially sustainable performance to expand the robustness and consistency of the research model.

Author Contributions: The research is designed and performed by K.S. and X.L.X. The data were collected by X.L.X. and H.H.C. Analysis of data was performed by K.S. Finally, the paper is written by X.L.X. and H.H.C. All authors have read and agreed to the published version of the manuscript.

Funding: This research was funded by [Youth Project of Humanities and Social Sciences of Ministry of Education in China] grant number [18YJC630213]; [Natural Science Foundation of Hunan Province] grant number [2019JJ50382] and [Key Project of Hunan Education Department] grant number [19A292].

Acknowledgments: We sincerely thank the editor and reviewers for their very valuable and professional comments.

Conflicts of Interest: The authors declare no conflict of interest. The founding sponsors had no role in the design of the study; in the collection, analyses, or interpretation of data; in the writing of the manuscript, and in the decision to publish the results.

\section{References}

1. Bointner, R. Innovation in the energy sector: Lessons learnt from RD expenditures and patents in selected IEA countries. Energy Policy 2014, 73, 733-747.

2. Qiao, S.; Xu, X.L.; Liu, C.K.; Chen, H.H. A panel study on the relationship between biofuels production and sustainable development. Int. J. Green Energy 2016, 13, 94-101. [CrossRef]

3. Yoshimoto, M. Nuclear disaster and bubbles. In Planetary Atmospheres and Urban Society after Fukushima; Thouny, C., Yoshimoto, M., Eds.; Springer: Singapore, 2017; pp. $29-50$. 
4. Xu, X.L.; Chen, Y.J. A comprehensive model to analyze straw recycling logistics costs for sustainable development: Evidence from biomass power generation. Environ. Prog. Sustain. Energy 2020. [CrossRef]

5. Brutschin, E.; Fleig, A. Innovation in the energy sector-The role of fossil fuels and developing economies. Energy Policy 2016, 97, 27-38. [CrossRef]

6. Nesta, L.; Vona, F.; Nicolli, F. Environmental policies, competition and innovation in renewable energy. J. Environ. Econ. Manag. 2014, 67, 396-411. [CrossRef]

7. Xu, X.L.; Yang, X.N.; Zhan, L.; Liu, C.K.; Zhou, N.D.; Hu, M.M. Examining the relationship between intellectual capital and performance of listed environmental protection companies. Environ. Prog. Sustain. Energy 2017, 36, 1056-1066. [CrossRef]

8. Mao, C.X.; Zhang, C. Managerial risk-taking incentive and firm innovation: Evidence from FAS 123R. J. Finan. Quant. Anal. 2018, 53, 867-898. [CrossRef]

9. Harrigan, K.R.; DiGuardo, M.C. Sustainability of patent-based competitive advantage in the USA communications services industry. J. Tech. Transf. 2017, 42, 1334-1361. [CrossRef]

10. Martin, G.P.; Wiseman, R.M.; Gomez-Mejia, L.R. Going short-term or long-term? CEO stock options and temporal orientation in the presence of slack. Strateg. Manag. J. 2016, 37, 2463-2480. [CrossRef]

11. He, Z.X.; Xu, S.C.; Li, Q.B.; Zhao, B. Factors that influence renewable energy technological innovation in China: A Dynamic PANEL approach. Sustainability 2018, 10, 124. [CrossRef]

12. Lai, W.H.; Lin, C.C.; Wang, T.C. Exploring the interoperability of innovation capability and corporate sustainability. J. Bus. Res. 2015, 68, 867-871. [CrossRef]

13. Pedersen, E.R.G.; Gwozdz, W.; Hvass, K.K. Exploring the relationship between business model innovation, corporate sustainability, and organisational values within the fashion industry. J. Bus. Ethics 2018, 149, 267-284. [CrossRef]

14. Przychodzen, J.; Przychodzen, W. Relationships between eco-innovation and financial performance-Evidence from publicly traded companies in Poland and Hungary. J. Clean Prod. 2015, 90, 253-263. [CrossRef]

15. Xu, X.L.; Chen, H.H. Exploring the relationships between environmental management and financial sustainability in the energy industry: Linear and nonlinear effects. Energy Environ. 2019. [CrossRef]

16. Bennett, B.; Bettis, J.C.; Gopalan, R.; Milbourn, T. Compensation goals and firm performance. J. Finan. Econ. 2017, 124, 307-330. [CrossRef]

17. Dobni, C.B.; Klassen, M.; Nelson, W.T. Innovation strategy in the US: Top executives offer their views. J. Bus. Strategy 2015, 36, 3-13. [CrossRef]

18. Behrens, J. A lack of insight: An experimental analysis of RD managers' decision making in innovation portfolio management. Creat. Innov. Manag. 2016, 25, 239-250.

19. Lo, F.Y.; Fu, P.H. The interaction of chief executive officer and top management team on organization performance. J. Bus. Res. 2016, 69, 2182-2186. [CrossRef]

20. Maas, K.; Rosendaal, S. Sustainability targets in executive remuneration: Targets, time frame, country and sector specification. Bus. Strategy Environ. 2016, 25, 390-401. [CrossRef]

21. Zou, H.L.; Zeng, S.X.; Lin, H.; Xie, X.M. Top executives' compensation, industrial competition, and corporate environmental performance evidence from China. Manag. Decis. 2015, 53, 2036-2059. [CrossRef]

22. Stam, E.; Wennberg, K. The roles of RD in new firm growth. Small Bus. Econ. 2009, 33, 77-89.

23. Yunis, M.; Tarhini, A.; Kassar, A. The role of ICT and innovation in enhancing organizational performance: The catalysing effect of corporate entrepreneurship. J. Bus. Res. 2018, 88, 344-356. [CrossRef]

24. Rosenbusch, N.; Brinckmann, J.; Bausch, A. Is innovation always beneficial? A meta-analysis of the relationship between innovation and performance in SMEs. J. Bus. Ventur. 2011, 26, 441-457. [CrossRef]

25. Hsu, C.-W.; Lien, Y.-C.; Chen, H. RD internationalization and innovation performance. Int. Bus. Rev. 2015, 24, 187-195.

26. Naranjo-Valencia, J.C.; Jiménez-Jiménez, D.; Sanz-Valle, R. Studying the links between organizational culture, innovation, and performance in Spanish companies. Revista Latinoamericana de Psicología 2016, 48, 30-41. [CrossRef]

27. Ciftci, M.; Cready, W.M. Scale effects of RD as reflected in earnings and returns. J. Acc. Econ. 2011, 52, 62-80.

28. Falk, M. Quantile estimates of the impact of RD intensity on firm performance. Small Bus. Econ. 2012, 39, 19-37.

29. Zabala, A.; Pascual, U.; García-Barrios, L. Payments for pioneers? Revisiting the role of external rewards for sustainable innovation under heterogeneous motivations. Ecol. Econ. 2017, 135, 234-245. [CrossRef] 
30. Xu, X.L.; Sun, C.H.; Chen, H.H. How diversified fuel-fired power enterprises keep their competitive advantages to reach sustainable development. Environ. Prog. Sustain. Energy 2019, 38, 137-142. [CrossRef]

31. Coles, J.L.; Daniel, N.D.; Naveen, L. Managerial incentives and risk-taking. J. Finan. Econ. 2006, 79, 431-468. [CrossRef]

32. Jacobsen, C.B.; Andersen, L.B. Performance management in the public sector: Does it decrease or increase innovation and performance? Int. J. Public Adm. 2014, 37, 1011-1023. [CrossRef]

33. Lui, A.K.H.; Ngai, E.W.T.; Lo, C.K.Y. Disruptive information technology innovations and the cost of equity capital: The moderating effect of CEO incentives and institutional pressures. Inf. Manag. 2016, 53, 345-354. [CrossRef]

34. Lu, X.; Sheng, Y.; Wang, J. The influence of executive compensation incentives on RD investment: The moderating effect of executive overconfidence. Technol. Anal. Strateg. Manag. 2020. [CrossRef]

35. Fong, E.A. CEO pay fairness as a predictor of stakeholder management. J. Bus. Res. 2010, 63, 404-410. [CrossRef]

36. Jensen, M.C.; Meckling, W.H. Theory of the firm: Managerial behavior, agency costs and ownership structure. J. Finan. Econ. 1976, 3, 305-360. [CrossRef]

37. Xu, X.L.; Chen, H.H.; Li, Y.; Chen, Q.X. The role of equity balance and executive stock ownership in the innovation efficiency of renewable energy enterprises. J. Renew. Sustain. Energy 2019, 11, 055901. [CrossRef]

38. Alessandri, T.M.; Pattit, J.M. Drivers of RD investment: The interaction of behavioral theory and managerial incentives. J. Bus. Res. 2014, 67, 151-158.

39. Zattoni, A.; Minichilli, A. The diffusion of equity incentive plans in Italian listed companies: What is the trigger? Corp. Gov. Int. Rev. 2009, 17, 224-237. [CrossRef]

40. Polder, M.; Veldhuizen, E. Innovation and competition in the Netherlands: Testing the inverted-U for industries and firms. J. Ind. Compet. Trade 2012, 12, 67-91. [CrossRef]

41. Schumpeter, J.A. The Theory of Economic Development: An Inquiry into Profits, Capital, Credit, Interest, and the Business Cycle; University of Illinois: Champaign, IL, USA, 1934.

42. Wadho, W.; Chaudhry, A. Innovation and firm performance in developing countries: The case of Pakistani textile and apparel manufacturers. Res. Pol. 2018, 47, 1283-1294. [CrossRef]

43. Xu, X.L.; Liu, C.K. How to keep renewable energy enterprises to reach economic sustainable performance: From the views of intellectual capital and life cycle. Energy Sustain. Soc. 2019, 9, 1-10. [CrossRef]

44. Deardorff, A.V. The general validity of the Heckscher-Ohlin theorem. Am. Econ. Rev. 1982, 72, 683-694.

45. Sher, P.J.; Yang, P.Y. The effects of innovative capabilities and RD clustering on firm performance: The evidence of Taiwan's semiconductor industry. Technovation 2005, 25, 33-43.

46. Higgins, R.C. Sustainable Growth under Inflation. Finan. Manag. 1981, 10, 36-40. [CrossRef]

47. Berman, S.L.; Wicks, A.C.; Kotha, S.; Jones, T.M. Does stakeholder orientation matter? The relationship between stakeholder management models and firm financial performance. Acad. Manag. J. 1999, 42, 488-506.

48. McCahery, J.A.; Sautner, Z.; Starks, L.T. Behind the scenes: The corporate governance preferences of institutional investors. J. Finance 2016, 71, 2905-2932. [CrossRef]

49. Xu, X.L.; Chen, H.H. Examining the efficiency of biomass energy: Evidence from the Chinese recycling industry. Energy Policy 2018, 119, 77-86. [CrossRef]

50. Ortiz-de-Mandojana, N.; Bansal, P. The long-term benefits of organizational resilience through sustainable business practices. Strateg. Manag. J. 2016, 37, 1615-1631. [CrossRef]

51. Cumming, D.; Rui, O.; Wu, Y.P. Political instability, access to private debt, and innovation investment in China. Emerg. Mark. Rev. 2016, 29, 68-81. [CrossRef]

52. Shahbaz, M. Does trade openness affect long run growth? Cointegration, causality and forecast error variance decomposition tests for Pakistan. Econ. Model. 2012, 29, 2325-2339. [CrossRef]

53. Shahbaz, M.; Mallick, H.; Mahalik, M.K.; Sadorsky, P. The role of globalization on the recent evolution of energy demand in India: Implications for sustainable development. Energy Econ. 2016, 55, 52-68. [CrossRef]

54. Xu, X.L.; Chen, H.H.; Feng, Y.; Tang, J. The production efficiency of renewable energy generation and its influencing factors: Evidence from 20 countries. J. Renew. Sustain. Energy 2018, 10, 025901. [CrossRef]

55. Colley, J.; Doyle, J.; Hardie, R.D. Corporate Strategy: How to Restructure a Business Unit to Best Support Corporate Goals; McGraw-Hill: New York, NY, USA, 2002.

(C) 2020 by the authors. Licensee MDPI, Basel, Switzerland. This article is an open access article distributed under the terms and conditions of the Creative Commons Attribution (CC BY) license (http://creativecommons.org/licenses/by/4.0/). 

MDPI

St. Alban-Anlage 66

4052 Basel

Switzerland

Tel. +41616837734

Fax +41 613028918

www.mdpi.com

Energies Editorial Office

E-mail: energies@mdpi.com www.mdpi.com/journal/energies

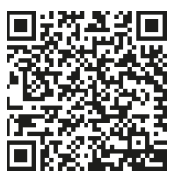



MDPI

St. Alban-Anlage 66

4052 Basel

Switzerland

Tel: +41 616837734

Fax: +41 613028918 